\title{
قضايا التغير الاجتهماعي في بعض مسرحيات مسرح الطفل في فترة الثمانينات
}

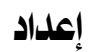

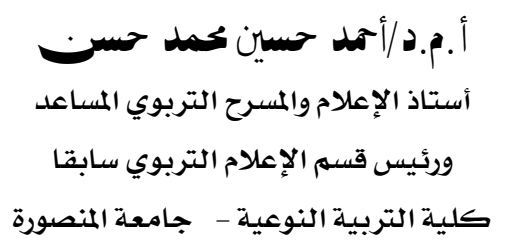

أ أ.د / محمود همام عبد اللطيف

أستاذ الديكور والفنون التعبيريـة المتفرع بكلية الفنون الجميلة - جامعة حلوان والرئيس الأسبق لقسه علوم المسرح كلية الأداب - جامعة حلوان

\footnotetext{
زينب أحمد السيد أبو سقيرة

المدرس المساعد بقسم الإعلام التربوي

كلية التربية النوعية جامعة المنصورة
}

مجلة بحوث التربية النوعية ـ جامعة المنصورة

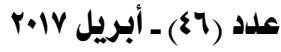

" بحث مستل من رسالة دكتوراه * 


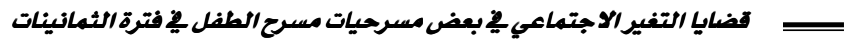

07. 


\section{قضايا التغيز الاجتماعي في بعض هسرحيات همرح الطفل}

\section{في فترة الثمانينات}

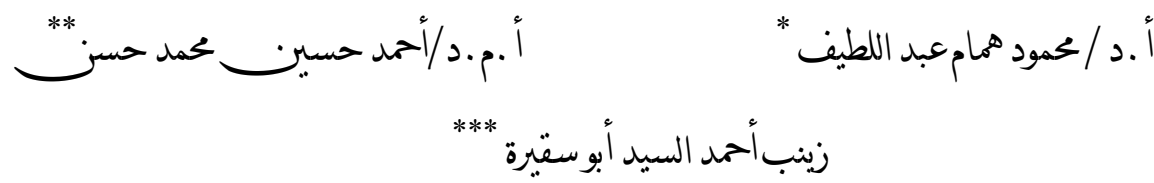

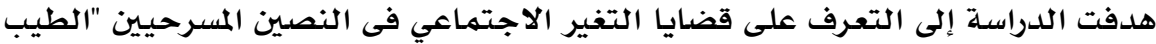

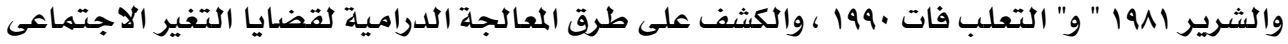

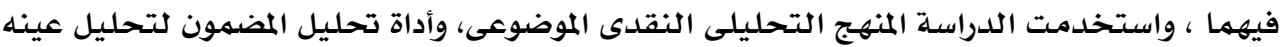

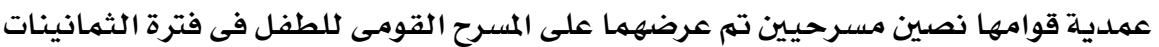

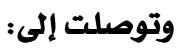

ساهمت مستجدات التغير الاجتماعى فى اختيار القضايا للنصين المسرحيين وتبلورت

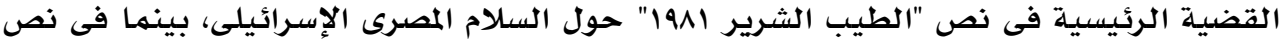
"التعلب فات •و199" حول: إنهاء الصراع العربى مـع الكيان الصهيو أمريكى بالوحدة والتكامل

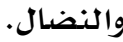

مقدمهنة:

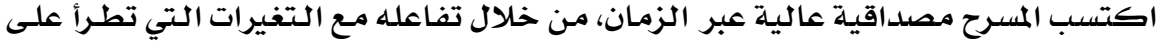

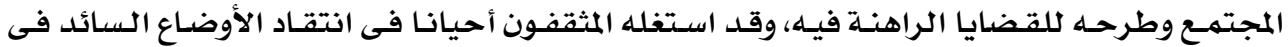

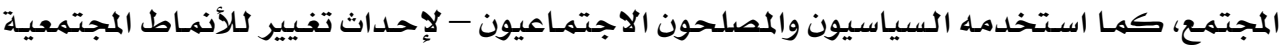

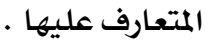
ومن المسلهم به أن مسرح الطفل هو فن من فنون المجتمـع التي تعكس واقعه وتطرح طموحاته،

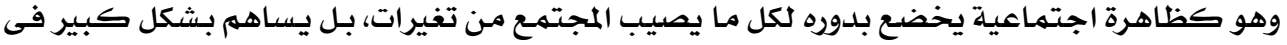

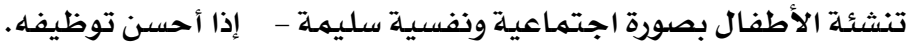


وقد ارتبط مسرح الطفل فى مصر منذ ظهوره ِِ المدارس بالمجتمع، وما يدور فيه مـن أحسداث

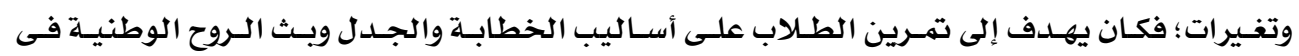

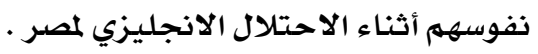

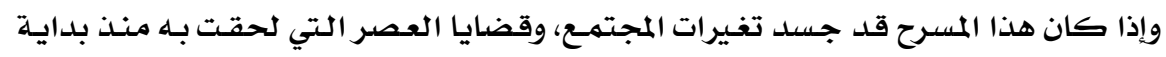

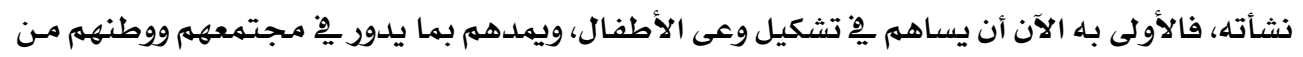

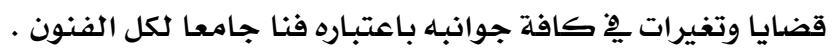

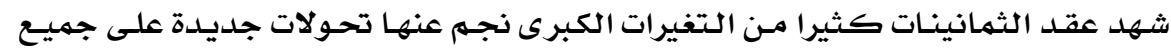

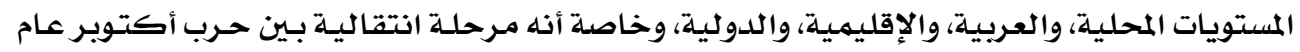

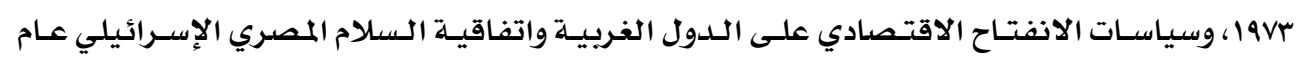

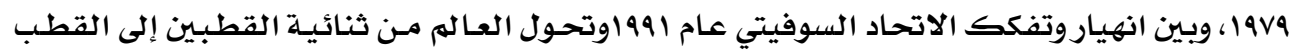

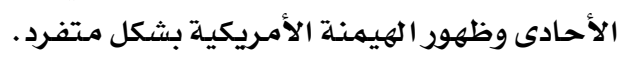

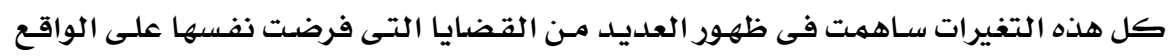

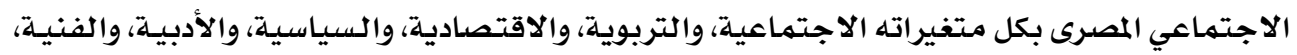

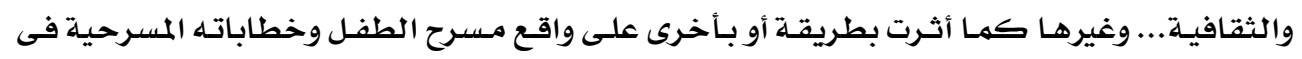

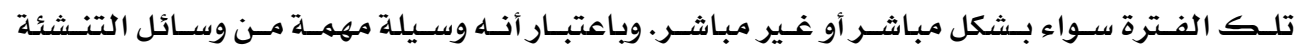

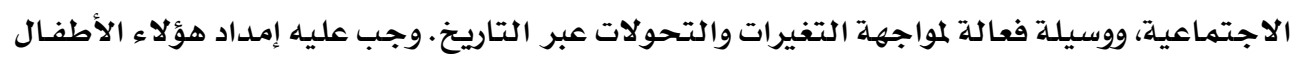

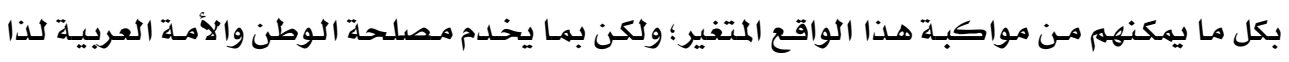

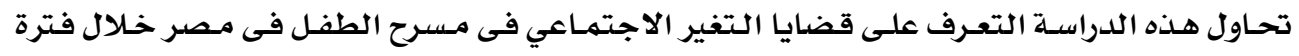
الثمانينات . أحاول هان

من هذا المنطلق تتبلور مشكلة الدراسة فى التساؤل الرئيسي التالي :

ما مدى انعكاس قضايا التغير الاجتماعي على بعض مسرحيات الطفل فى مصر فى فترة

الثمانينات

ويتفرع من هذا التساؤل عدة تساؤلات فرعية تتمثل يِّ :

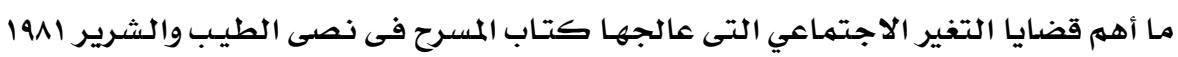

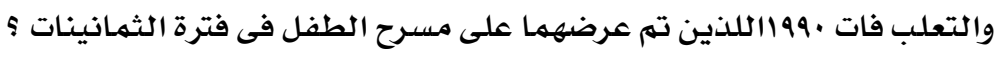

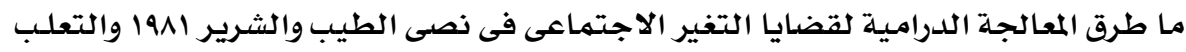

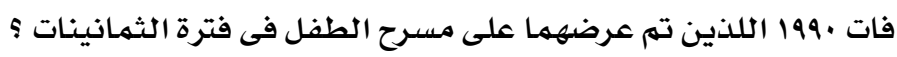

أهداف الدراسة :

- التعرف على قضايا التغير الاجتماعي فى النصين المسرحيين موضوع الدراسة. 
مجلة بحوث التربية النوعية - علد T ع - أبريل r.IV

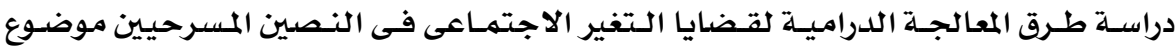

الدراسـة .

\section{أهمئة الدراسة :}

تأتى أهمية الدراسـة من أهمية الموضوع الذى تتناولـه الدراسـة، وهو قضايا التغير الاجتمـاعي

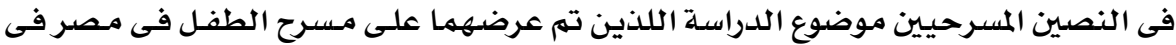

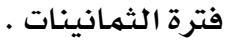

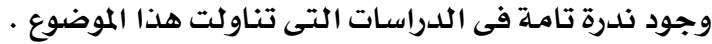

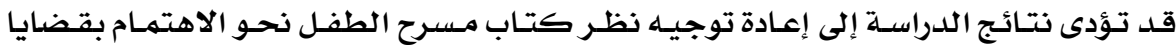

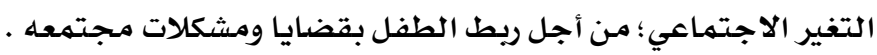

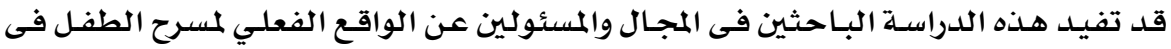
مصر.

\section{هدود الدراستة:}

تتمثل حدود الدراسة يِّة :

الحسـدود الموضـوعية: دراســة قـضايا الـتغير الاجتهــاعي فـى مسـرحيات الأطفــال فـى فـترة الثمانيات . الخدات

الحدود الزمانية : النصوص المسرحية المعروضدة للأطفال فى فترة الثمانينات .

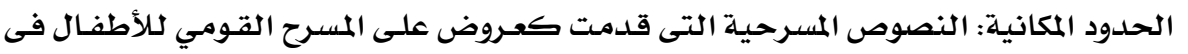

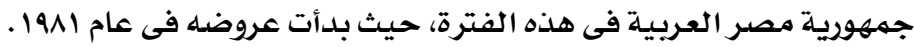

\section{مصطات الدراسة:}

تتحدد مصطلحات الدراسة ِِِ التالي:

- التغير الاجتماعي: تعرفه الباحثة إجرائيا بأنه: التغير الذي يحدث داخل المجتهـع أو التحول الذي ماني

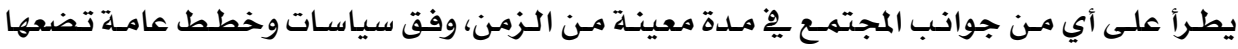

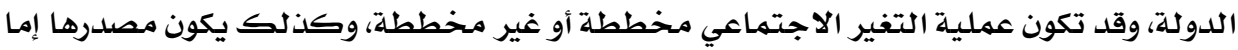
داخلي أو خارجي.

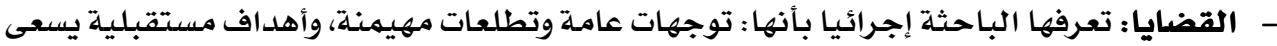

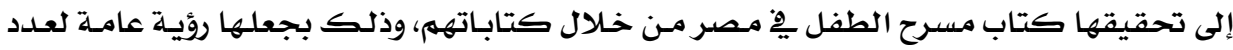

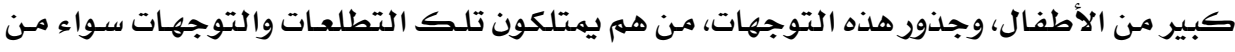

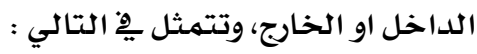

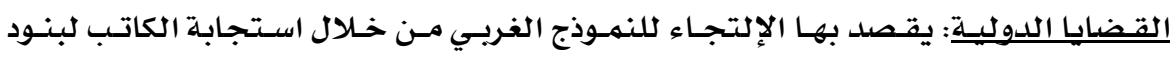

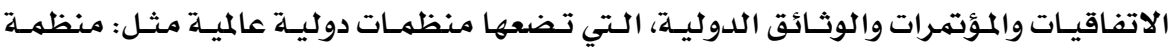


اليونسكو، والجمعية العامـة للأمم المتحدة ، الصندوق الدولي ..إلى غير ذلك ويحاول الكاتب

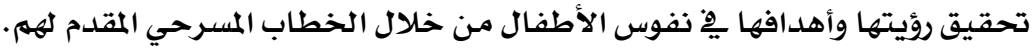

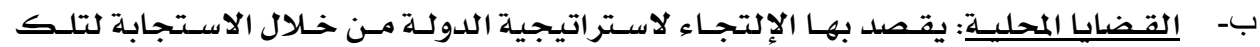

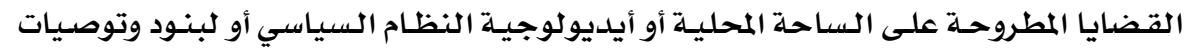

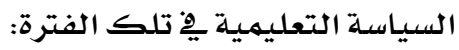

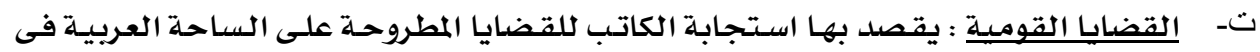
تلك الفترة ويسعى الكاتب إلى جعلها رؤية عامـة فى نفوس الأطفال.

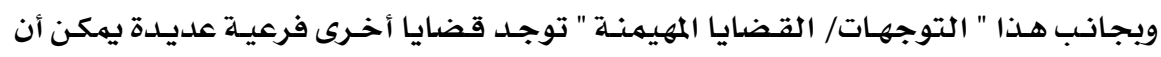

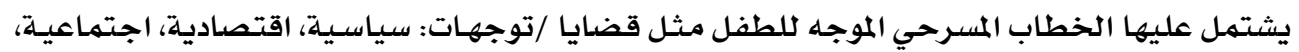

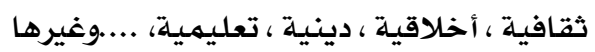
- مسرحيات الأطفال: - ماله تعرفها الباحثـة إجرائيـا بأنها : النصوص المسرحية التي عرضت على مسرح الطفل خلال فترة الثمانينات . وتعرف الباحثة النص المسرحي إجرائيا بأنه: فن أدبي يقوم على الحوار يعالج قضيـة معينـة

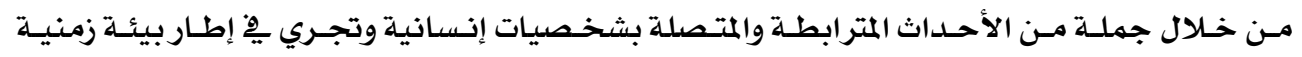
ومكانية معينة .

\section{الدراسات السابقة :}

من خلال مححاولة الاطلاع على الأبحاث والدراسات العربية والأجنبيـة التي سبقت الدراسـة

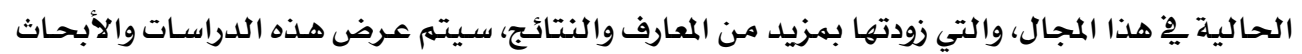

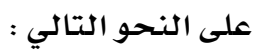
ا ـ دراسة : أحمد سمير بيبرس (19Vr) :

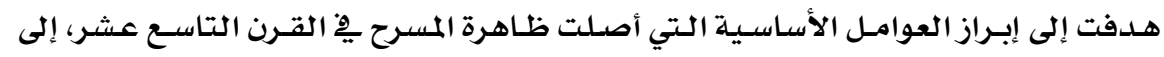

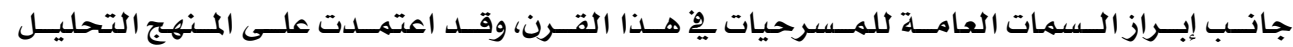

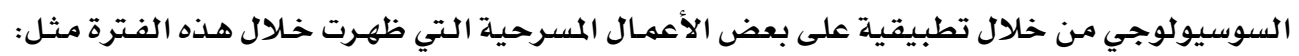

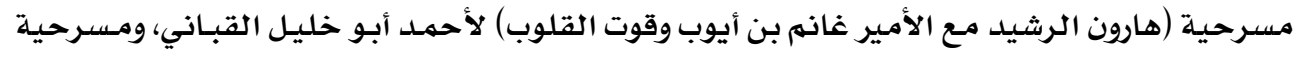

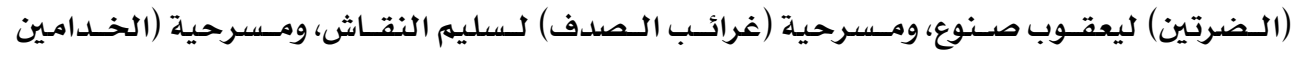

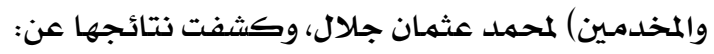

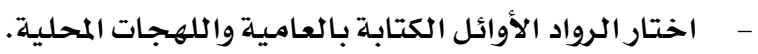

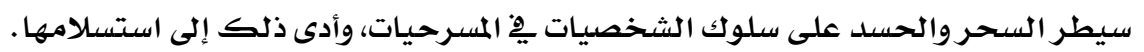
شاعت الألفاظ الأجنبية نظرا للمكانة العظيمة التي تمتعت بها الجات الجاليات الأجنبية. شاع النفاق والتقرب من السلطات يِّ المسرحيات. 


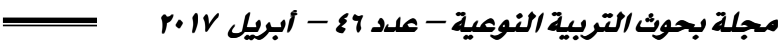

كانت الطبقية واضحة بأبهى مظاهرها يٌْ علاقات الشخصيات وتعاملها وعواطفها.

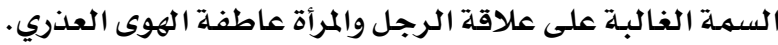

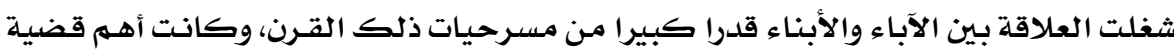
عرضتها هذه المسرحيات زواج الابن والابنة. سادت الشخصيات النهطية المسطحة على شخصيات.

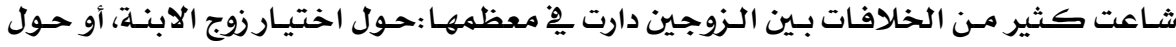

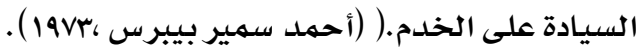
r. ب. دراسة : أحمد جودة السعدني (19V7):

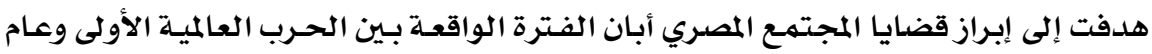

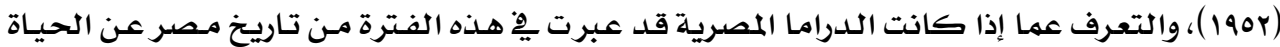

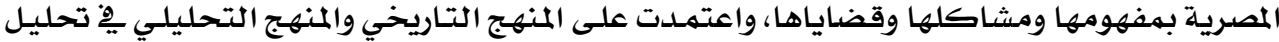

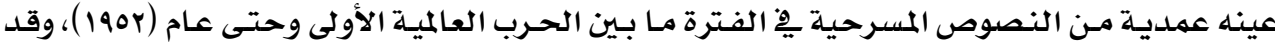

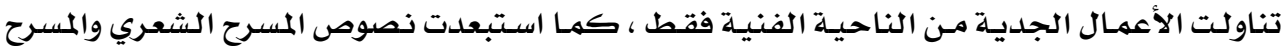

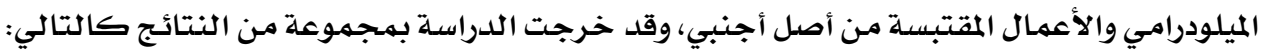

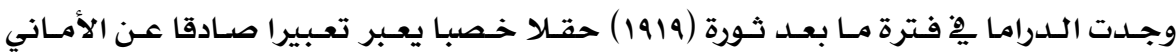
القومية.

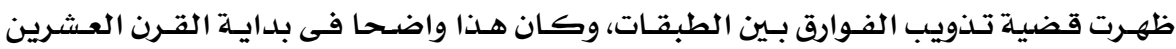

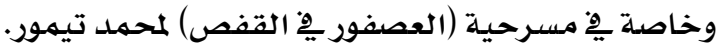

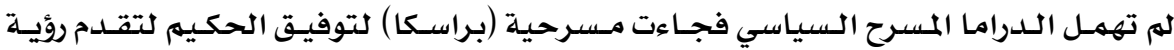

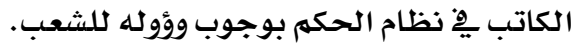

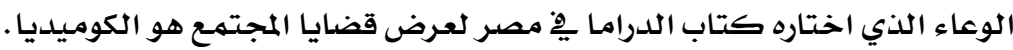

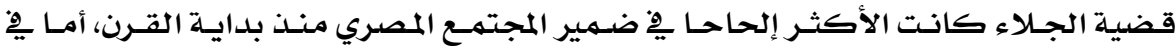

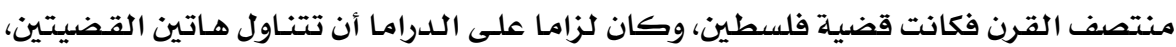

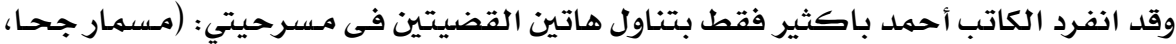

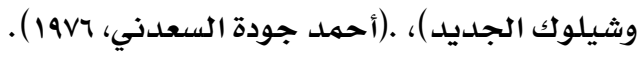
r. دراسة : يوسف عبد العزيز إبراهيم (19V7) : هدفت إلى توضيح جهود المسرح المصري يِّ تناولـه لقضية الحريـة بكافة أشكالها وصورها،

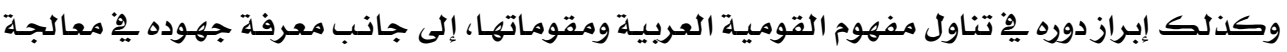

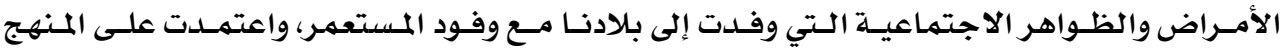

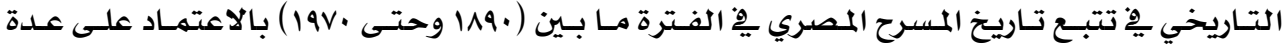
مصادر مثل: الكتب التي عالجت الفن المسرحي وكتب التاريخ، وأظهرت الدراسـة مـجموعة من النتائج كالتالي: مدادئ: 


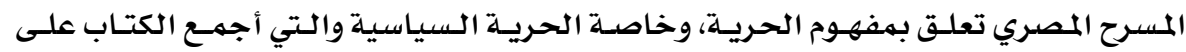

انعدامها يخ عالمنا العربي. المبري.

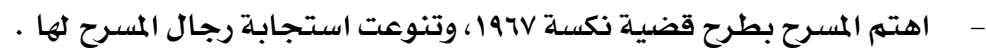

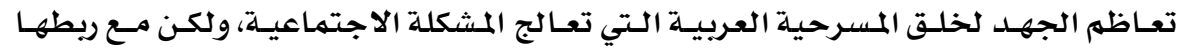

بالمشكلات الوطنية يِّو عالمنا العربي.

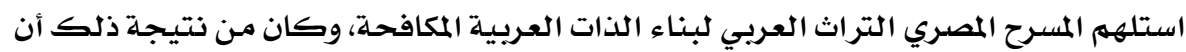

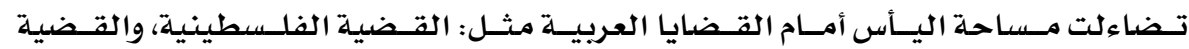
الجزائريـة.

لهم يحفل المسرح المصري بالعيوب الاجتماعية الفردية مثل: مشكلة الانحراف السلوكي عنــ الأفراد

انصب اهتمام المسرح على استهجان بعض الظواهر الاجتماعية مثل: الفقر والجهل والإقطاع والتقليد الأعمى.

دخل المسرح معـارك مباشـرة مـع المستعمـر وأعوانـه مـن الحكام. (يوسف عبــ العزيـز إبراهيم ،

. (19v7

ع. دراسة: كمال الدين حسين (1910):

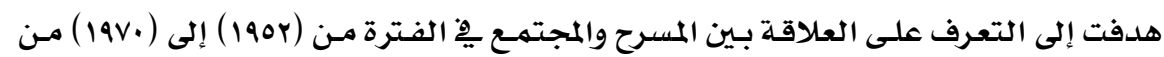

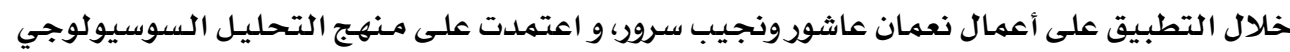

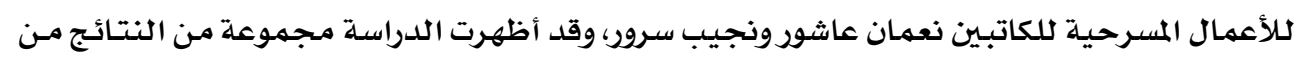
أهمها :

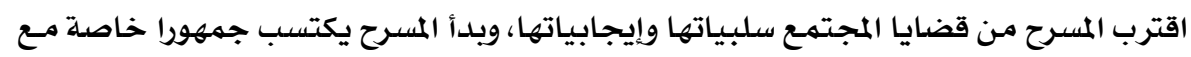

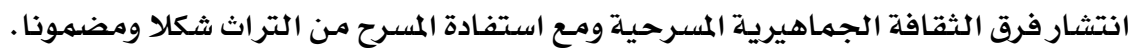

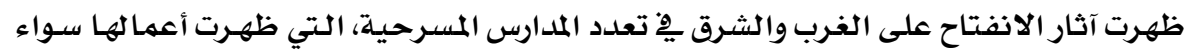

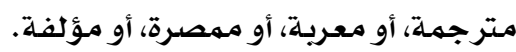

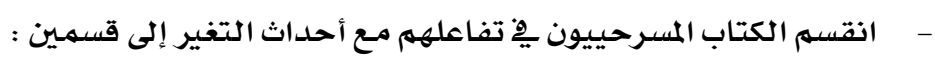

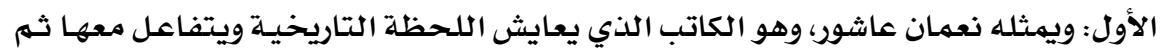

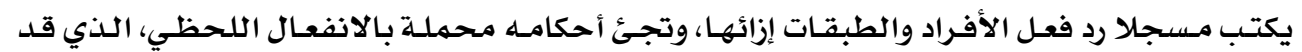

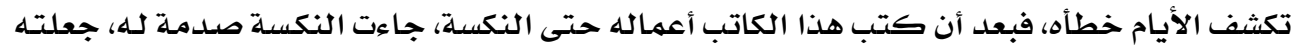

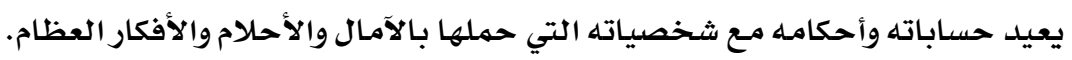

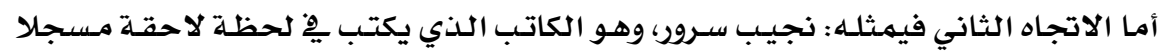

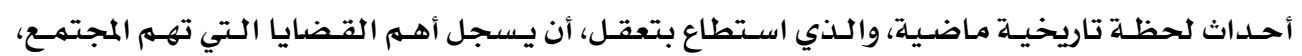

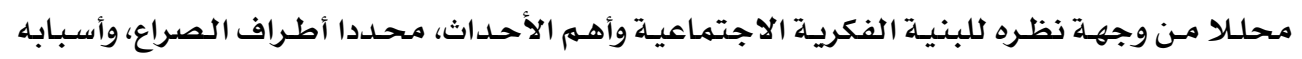




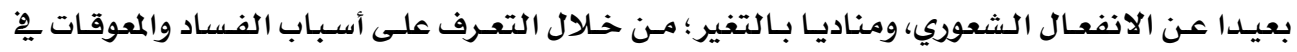

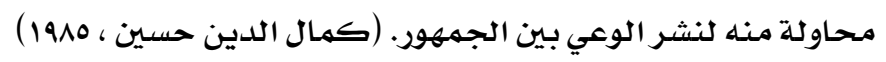
ه. دراسة: بن دهيبة بن نكاع (.199) :

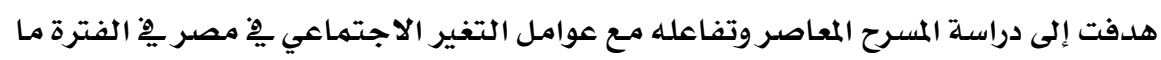

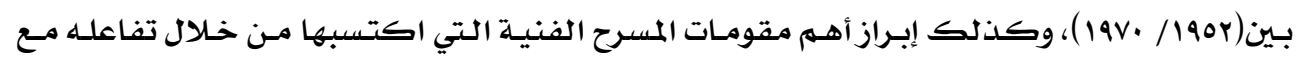

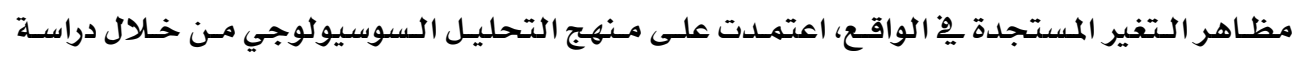

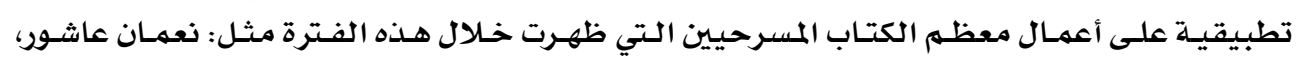

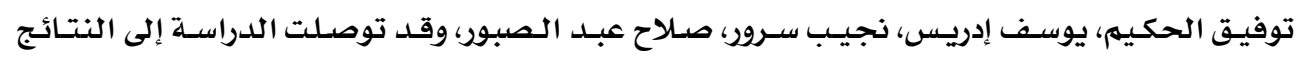
التتاليـة : توفيتق احت

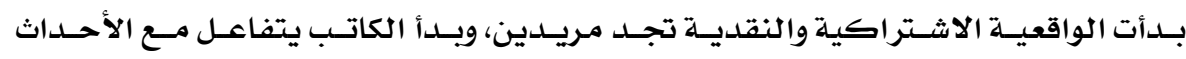

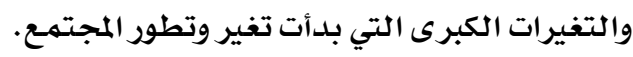

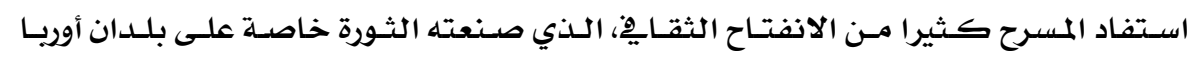

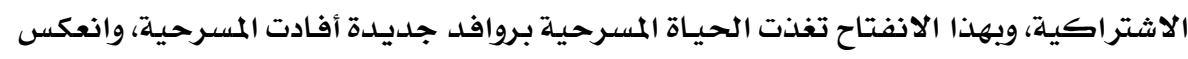
هذا المسرح كتابة وعرضا.

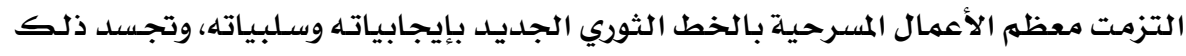

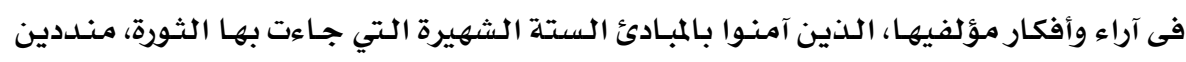

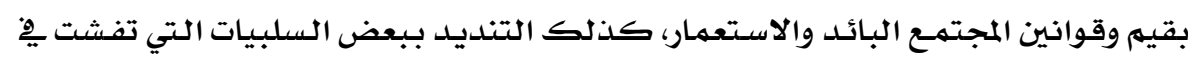

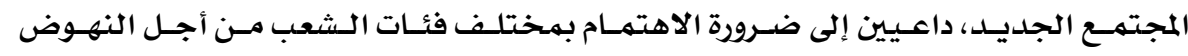

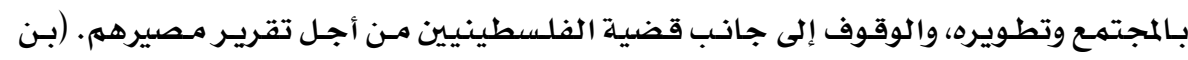
دهيبة بن نكاع • 1999).

\section{7. دراسة: Morrison, Joy, Florence)}

هدفت إلى تقييم مسرح المنتدى كوسيلة هامـة للاتصال مـع النـاس الريفيين ِِّ بوركينا

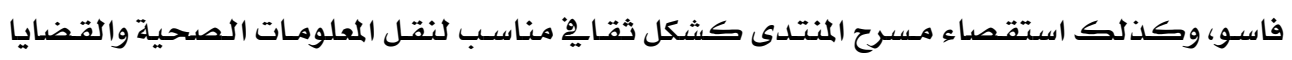

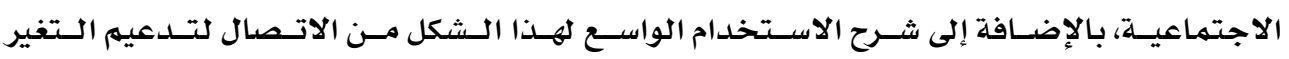

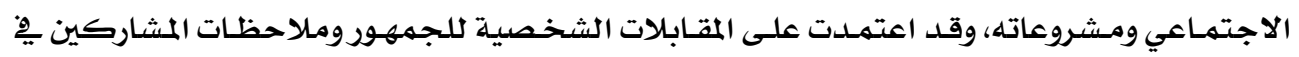

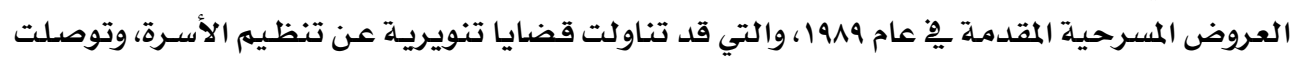

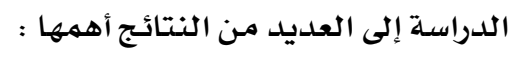

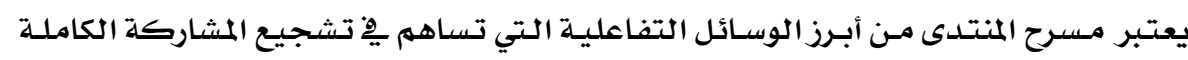

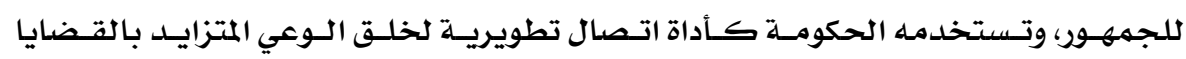
الاجتماعية ِِِ كل مكان بالدولة. ظهر هذا الشكل المسرحي كوسيلة شعبية للتعليم الاجتماعي، وهو بمثابة أداة تعليمية مهمة ووسيلة للتعبير الثقايِّ الجيد. 


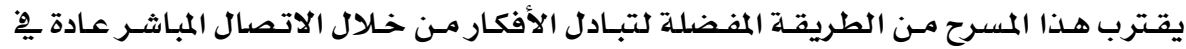

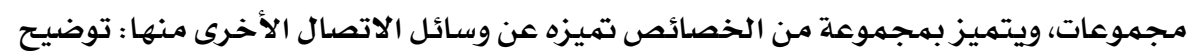

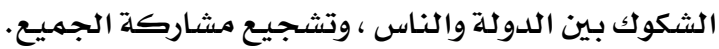

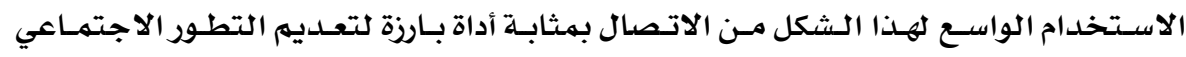

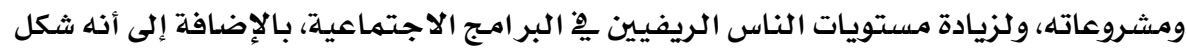
مقبول ثقافيا ومكمل لحملات وسائل الإعلام.

\section{(1991), Morrison, Joy, Florence)}

: (1992), Paavolainen, Pantti Jalmari : دراسة v . v هدفت إلى تقديم وصف لمسرح الطفل سيرى موتو الفيلندى من (1909/19V1)، وقد اعتمـدت

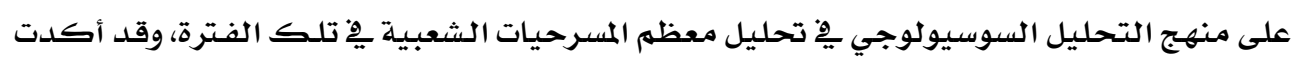

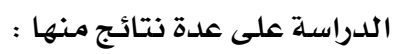
وصفت المسرحيات الشعبية صراع الجيل، وعملت على حله بشكل متجانس.

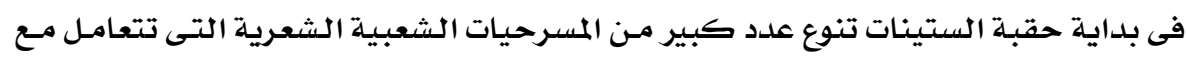

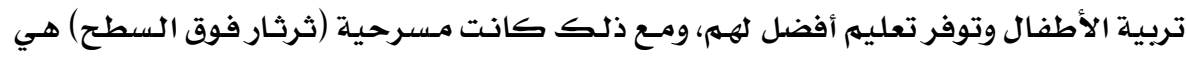

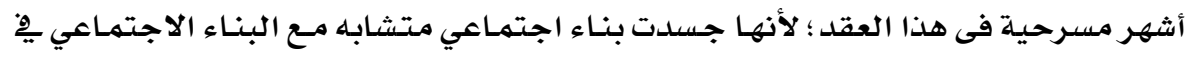

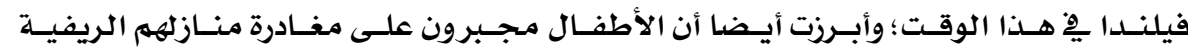

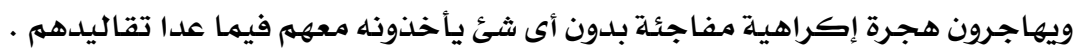

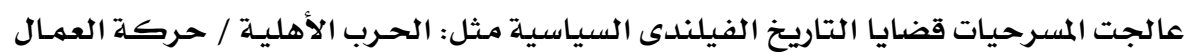

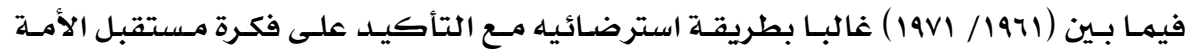

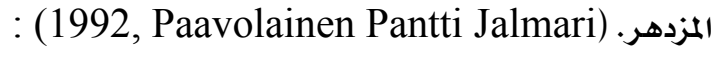
^. دراسـة : Dorota), Rundnicka- Kassem , (1992),

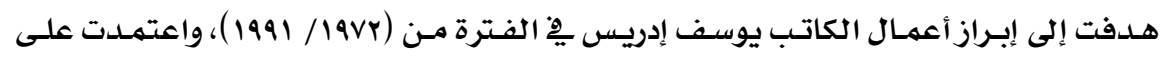

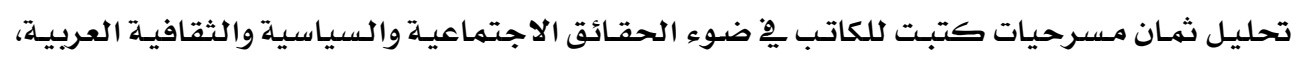

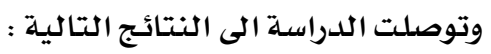

ساهم يوسف إدريس إسهاما كبيرا ِِّ تعميق جذور الهوية العربية والبحث عنها.

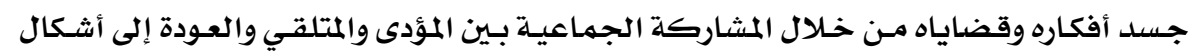
الفرجة الشعبية الجماعية. عكست مسرحياته ووثقت عصر ما بعد الثورة المصرية (190r) )، ودعت للتغيير والإصلاح.

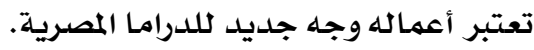

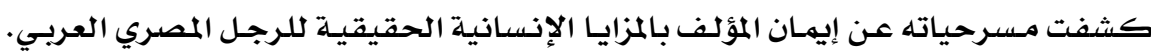
(1992, Rundnicka- Kassem ,Dorota) 
9. دراسة: عثمان عبد المعطى عثمان (1999).

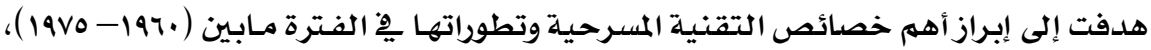

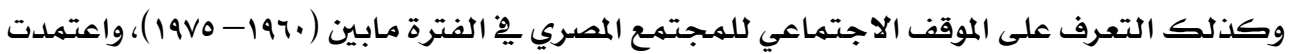

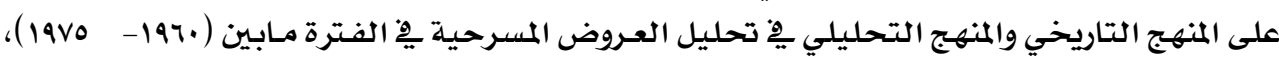
وقد أظهرت الدراسة مجموعة من النتائج من أهمها :

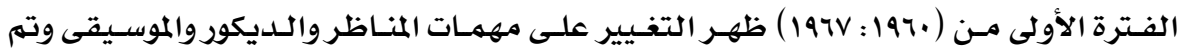
إزالة الحوائط والبنوهات.

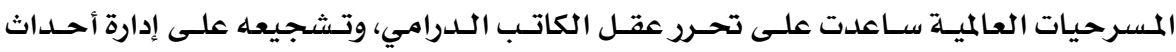

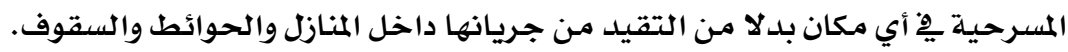

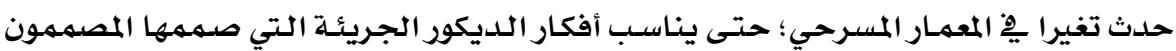

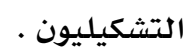

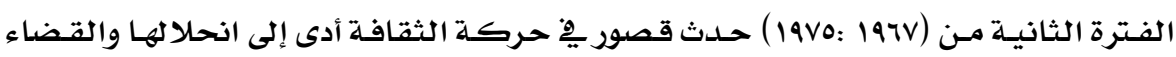

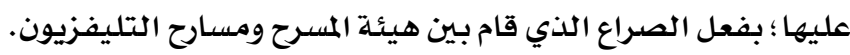

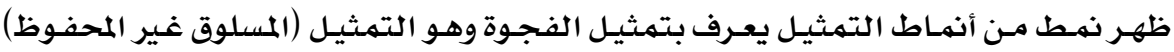

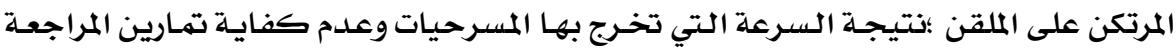

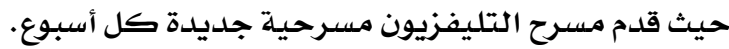

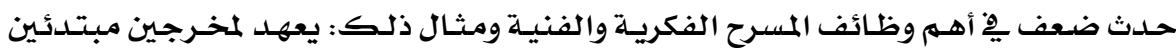

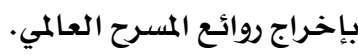

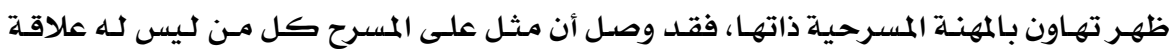
بالفن أو الثقافة على وجه الإطلاق.

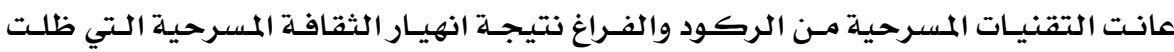

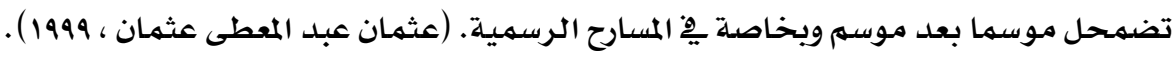

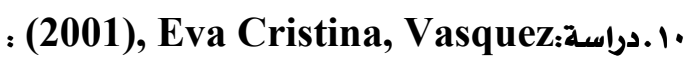

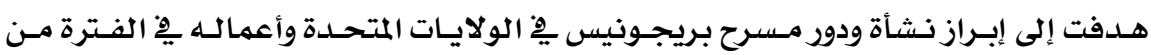

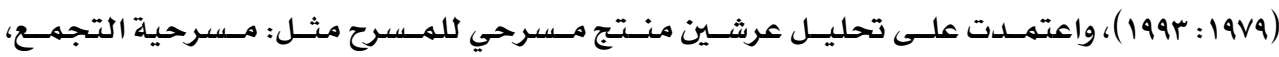

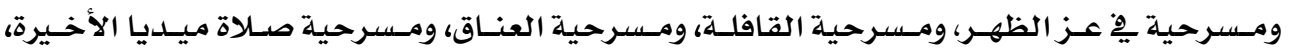

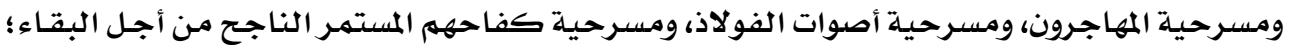

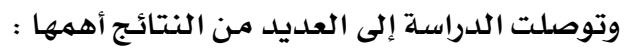

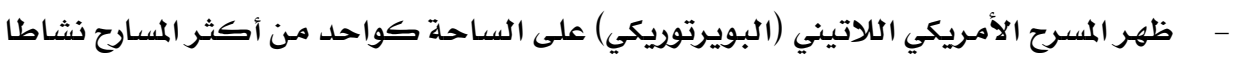

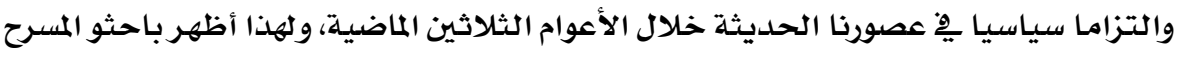

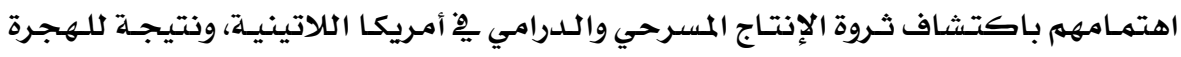




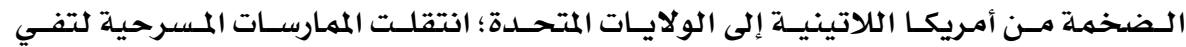

بالاحتياجات الثقافية للـجماعات المهاجرة خلال النصف الثاني من القرن العشرين.

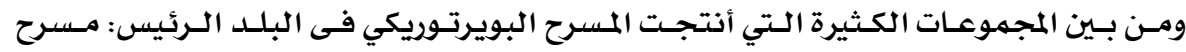

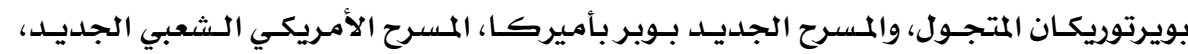
ومسـرح أوريـلا مسـرح الشـاطئ، ومسـرح جورتونجـو، ومسـرح كوارتو ومبــئيـا اهتمـت كل مـن

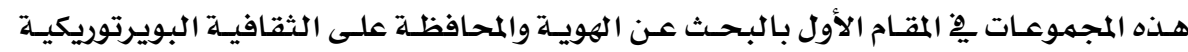
كما ركزت عملها على تحقيق هذه الأهداف نفسها من منظور اجتماعي وسياسي . 2001 (Eva Cristina, Vasquez)

\section{1).دراسة: (2002), Sukhwant Hundal. B.A}

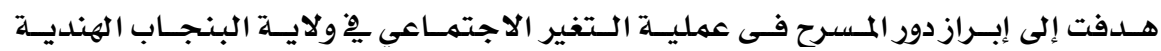

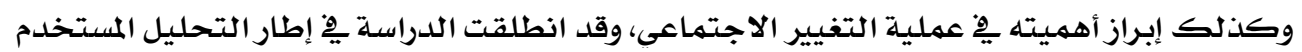

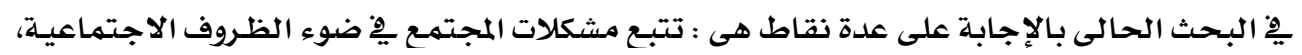

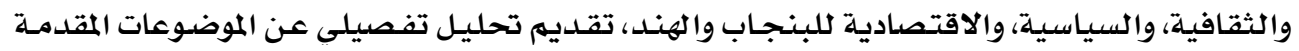

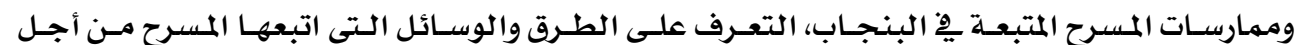
التغيير الاجتماعي.

$$
\text { وتوصلت إلى عدة نتائج كالتالي: }
$$

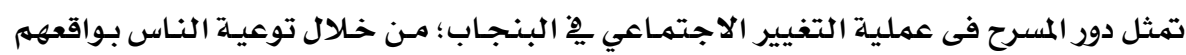
الظالم، والكثف عن الطرق والوسائل العديدة لتغيير هذا الواقع.

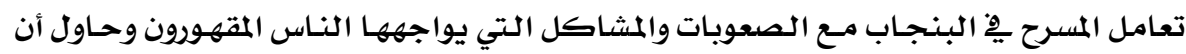
يكشف عن أسباب هذه المشاكل للمسؤليين.

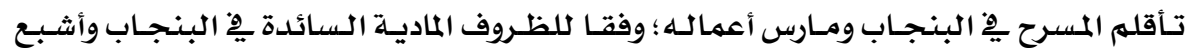

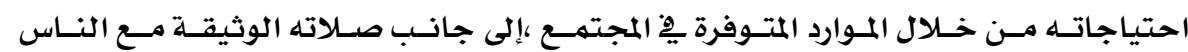
ومنظماتهم.

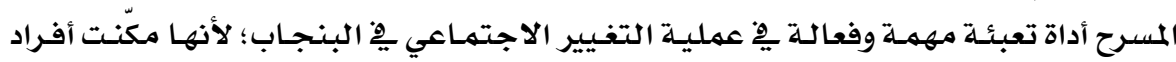
الجمهور ومهارسي المسرح من مواجهة القهر والظلم. المسرح مكن جمهوره إلى أن يصل إلى مـا يبغى وأن يعيث على المدى الطويـل سعيد . 2002 ) .Sukhwant Hundal. B.A.)

$$
\text { rا .دراسةة: محمد عبد الحليم سرور، (rا.r): }
$$

هدفت إلى التعرف على قدرة المسـرح التعليهي فى مواكبة مـا طرأ على المجتهـع المصري مـن تغيرات اجتماعيـة خلال ثورة هب يناير، والتعرف علي أسـاليب إخراج عروض المسرح التعليهي، واعتمدت هوت الدراسـة على المنهج الاجتماعي التحليلي فى تحليل عينه عمدية مـن الأنشطة المسـرحيـة المقدمـة داخل 
إدارة التربية والتعليه بالقاهرة للثلاث سنوات السابقة للثورة واللاحقة لها وجاءت النتائج على النحـو

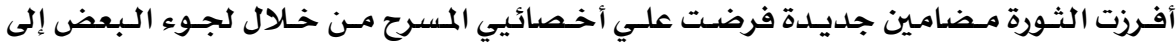

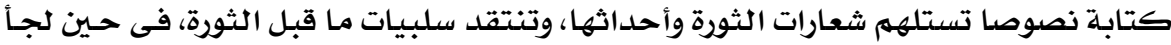

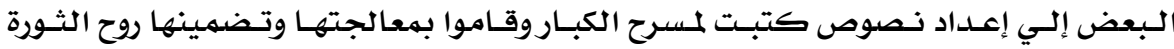

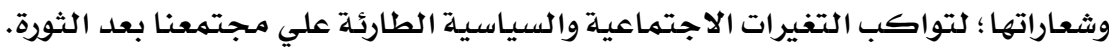

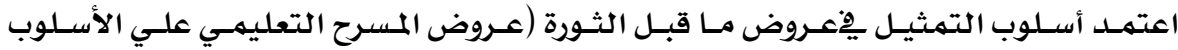

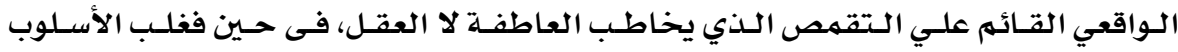

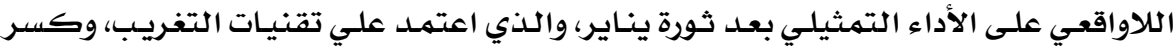

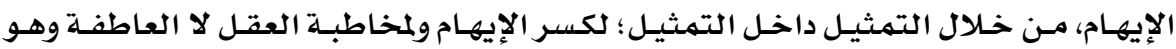

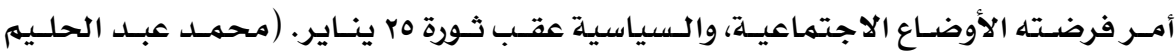

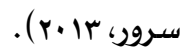

\section{تعقيب على الدراسات السابقة:}

من خلال المحاولة فى عرض مجموعة الدراسـات السـابقة، والتى تمثلت فى سبعـة دراسـات

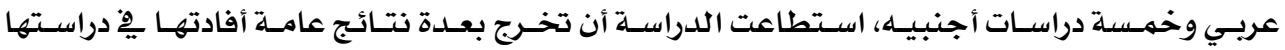

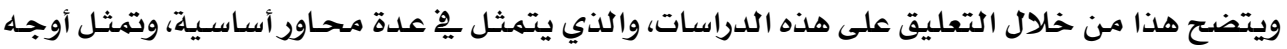
الاستفادة منها كالآتي: أولا : من حيث الموضوع: انصب اهتمام القائمـين بالدراسات العربية يِّ تناول موضوعات مثل: استخلاص أهم قضايا

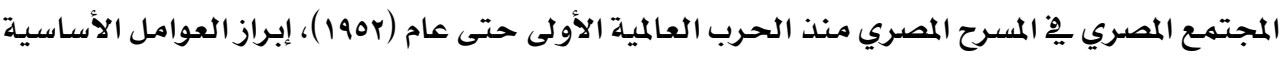

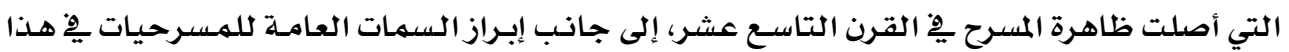

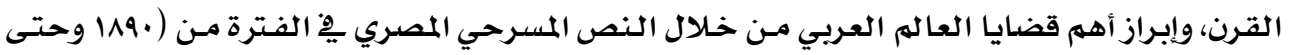

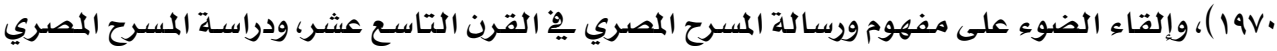

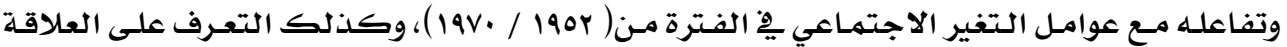

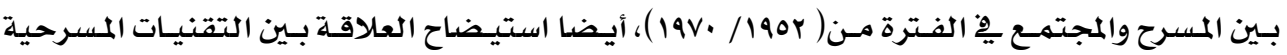

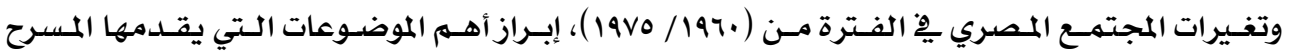

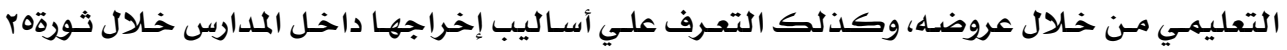
يناير.

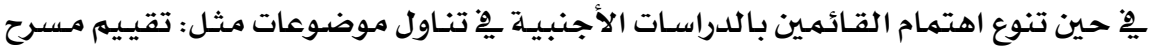

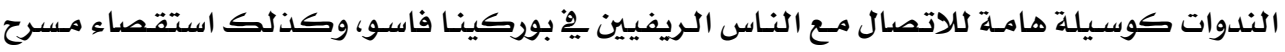

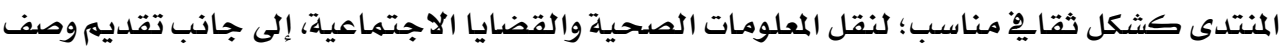

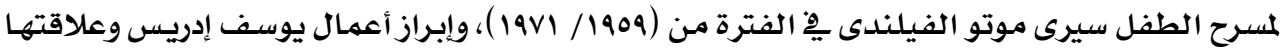


بعوامل التغير الاجتماعي ِِّ الفترة من (19VY / (1991)، بالإضافة إلى تتبع نشأة وتاريخ مسرح الطفل

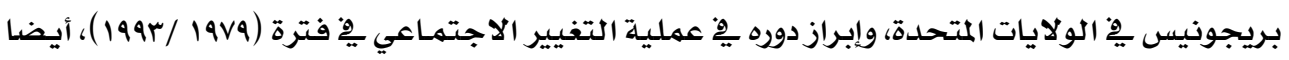

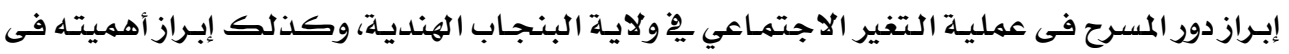
عملية التغيير الاجتماعي). ثانيا : من حيث النتائج :

من خلال محاولة الباحثة لعرض مجموعة من الدراسات السابقة يتضح ما يلي : ركزت الدراسات العربية السابقة على دراسة المسرح المصري بشكل عام وعلاقتته بعوامل التغير

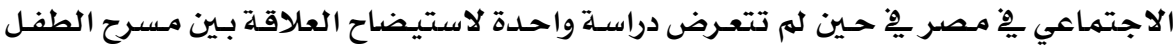

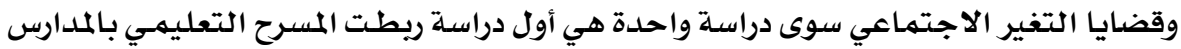

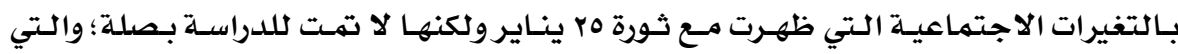

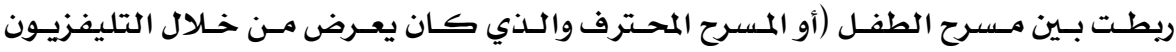

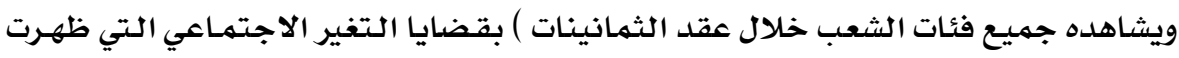
آنذاك . ركزت معظم الدراسات العربية على دراسة المسرح المصري وعلاقته بعوامل التغير الاجتماعي

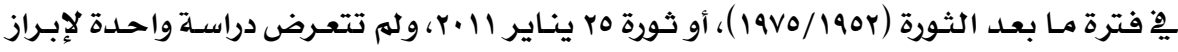

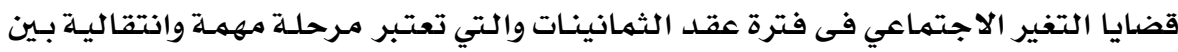

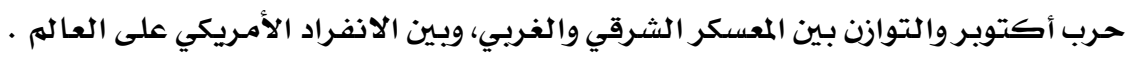

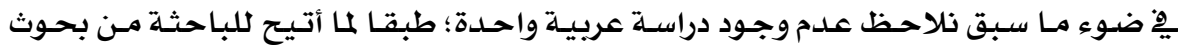

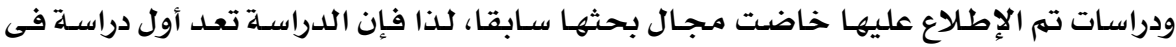

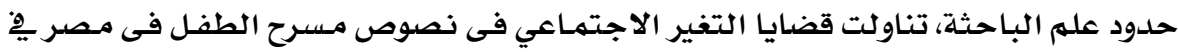

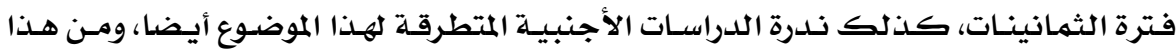

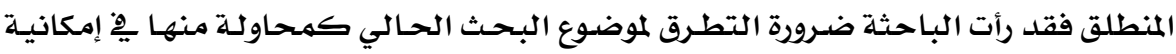

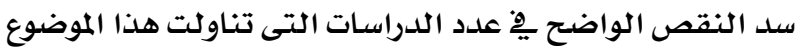

\section{موقع الدراسة الحالية من الدراسات والبحوث السابقة:}

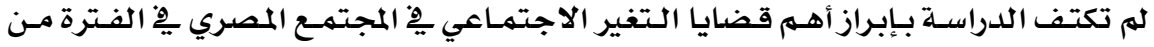

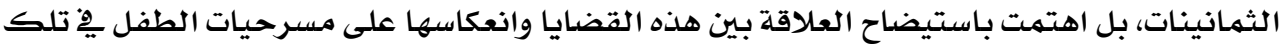

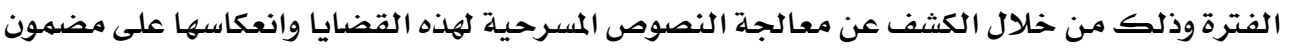

$$
\text { وبنية المسرحية. }
$$

\section{أوجه الاستفادة من الدراسات السابقة:}

$$
\text { تحديد مشكلة الدراسلة . }
$$

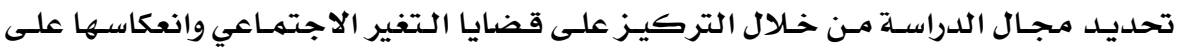




$$
\text { بلورة مشكلة البحث ووضع التساؤلات الحالية }
$$

الاهتداء إلى المراجع البحثية والاستعانة بها فى كتابة الجزء البحاء النظري، والذي سنتطرق له هي.

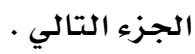

\section{الإطار النظري للدراسة:}

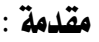

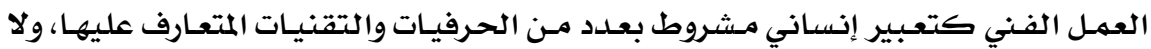

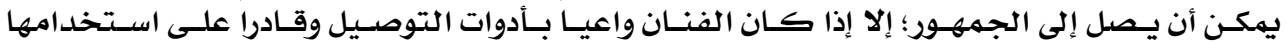
الاستخدام الأمثل. - ان.

والمسرحية كفن أدبي لـه مقوماتـه الخاصـة التـى تميزه عن سـائر الفنـون الأخـرى، وتعتمـد

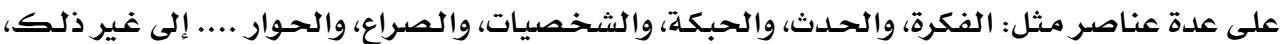

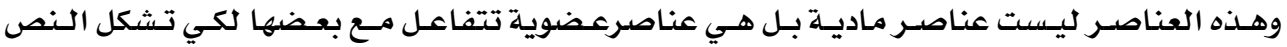

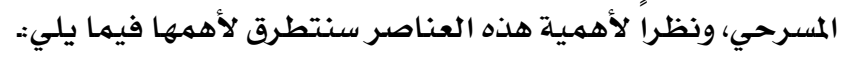
عناصر (البناء الدرامي):

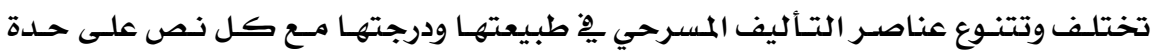

$$
\begin{aligned}
& \text { وتتمثل هذه العناصر يِّ : } \\
& \text { أولا : الأجزاء الكمية : }
\end{aligned}
$$

إذا ما نظرنا للمسرحية على أسـاس كهـي نجــ أنها تتكون مـن فصل أوعدة فصول، كما

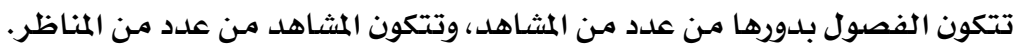
ثانيا :الأجزاء الكيفية : لعل أبرزها يتحدد بِّ التالى :

1. 1. الفكرة:

تعتبر الفكرة هي المغزى أو الهدف من العمل الدرامي، ويقصد بالفكرة على العمـوم " الحقيقـة

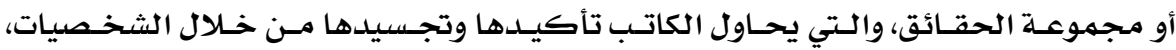

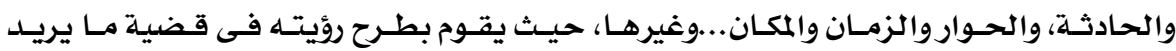

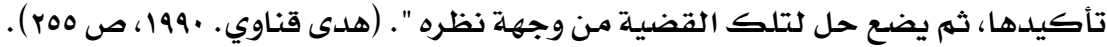

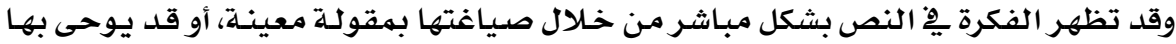

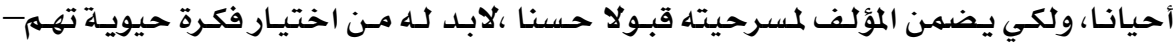

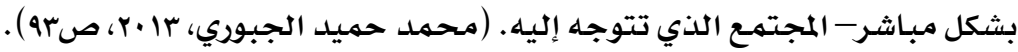

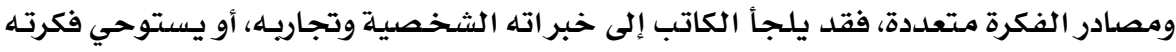

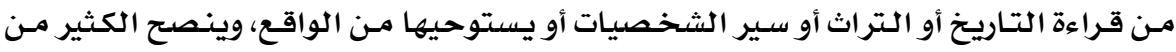

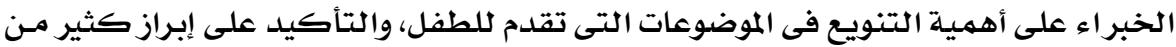


القضايا المعاصـرة؛ لتوجيـه الأطفـال نحـو اكتسـاب خبر ات متعـددة تسـاعدهم على مواجهـة

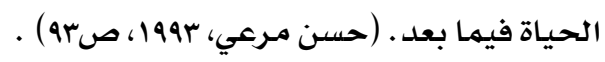

r. الحدث :

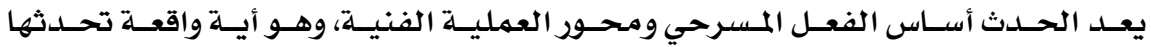

الشخصيات فى حيزي الزمان والمكان، وتسهـه في تشكيل الحركة الدرامية والفعل المسرحي. (إبراهيم

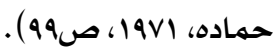

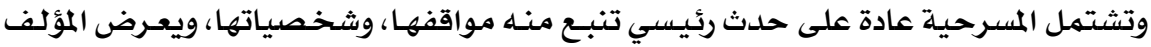

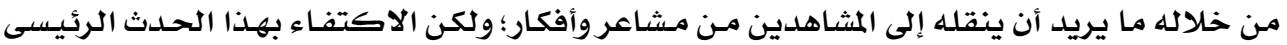

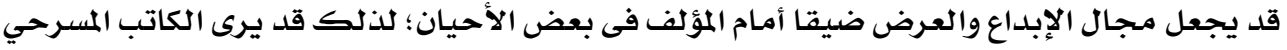

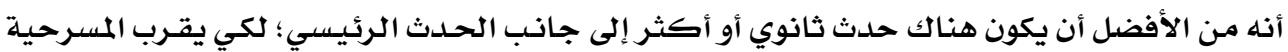

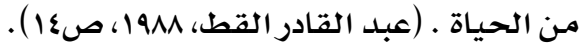
r. الحبكة :

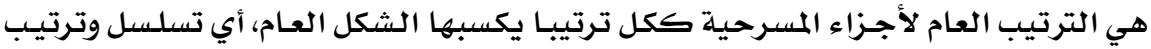

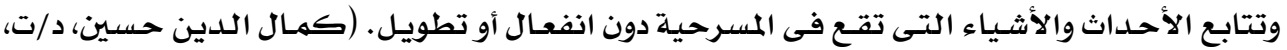

$$
\text { وتنقسهم إلى : كة : }
$$

أ- أ حبكة بسيطة : 20 - 20

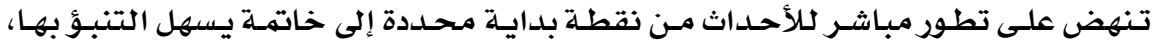

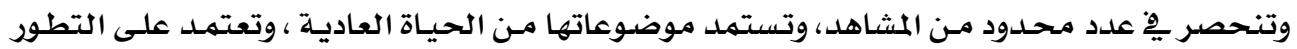

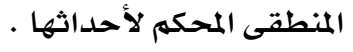

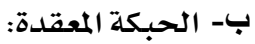

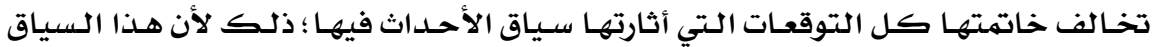

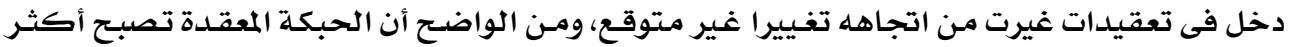

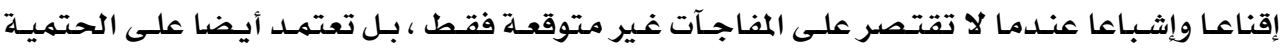

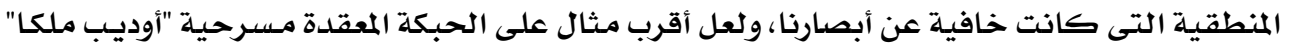

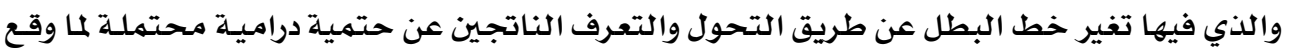

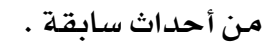
ج- الحبكة المركبة : تتكون من حبكتين بسيطتين أو معقدتين أو حبكتين إحداهما بسيطة والأخرى معقدة كما

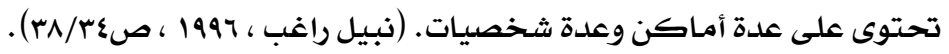


: ع . الصراع

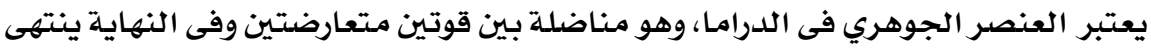

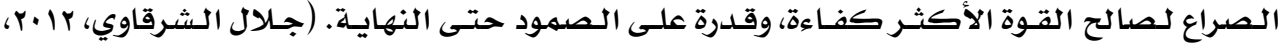
ص. (1) (1)

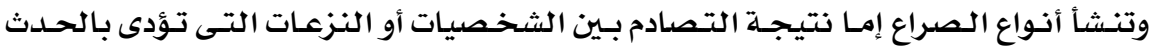

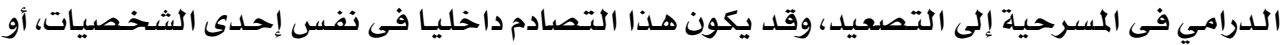

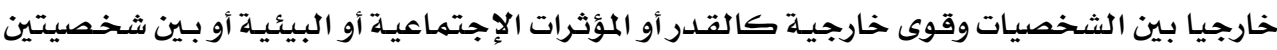

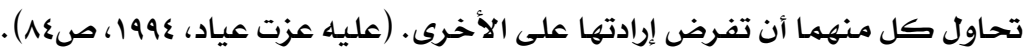

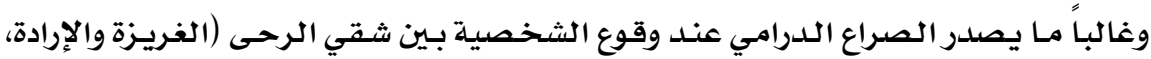

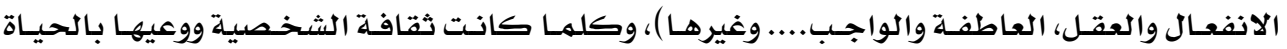

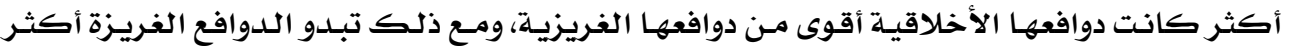

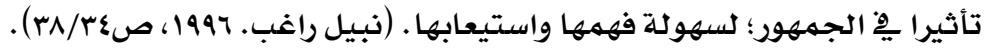
ه. الشخصيات :

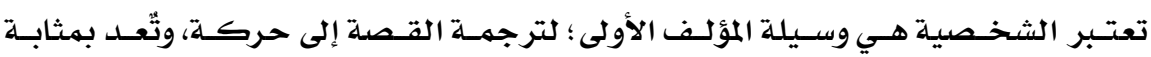

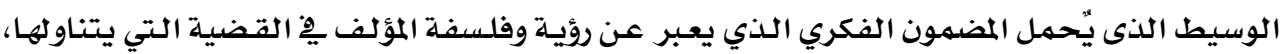

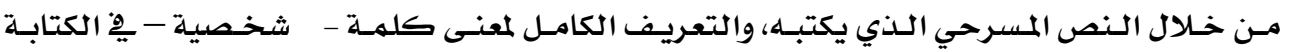

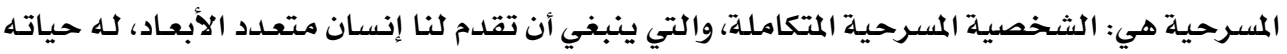

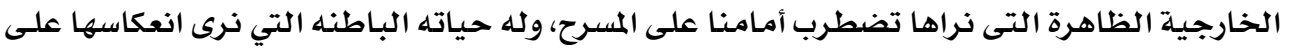

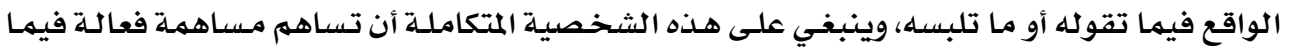

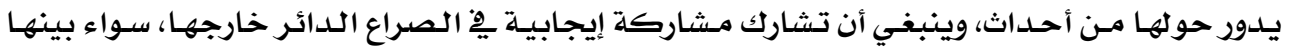

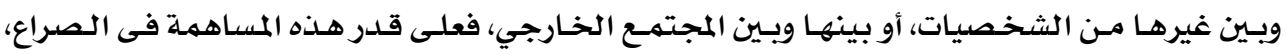

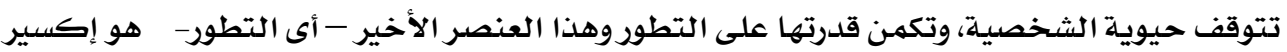

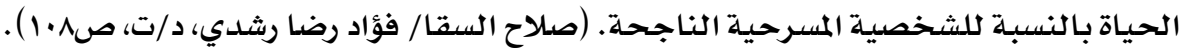
وهناك عددا من الملامح لابد للشخصية المسرحية أن تمتلكها ؛ حتى يتعرف عليها الجمهور

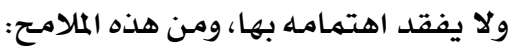

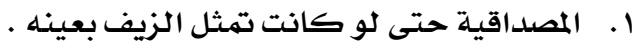

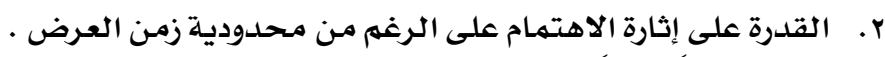

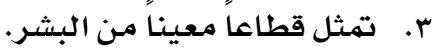

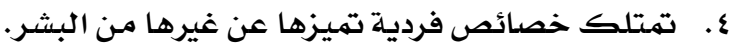

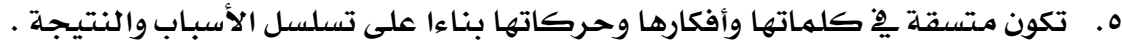

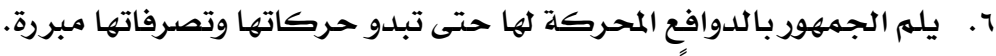
V V . أن تكون متطورة تبعا لاحتكاكها بالحياة. 
^. .أن تمتلك خاصية واحدة تميزها عن غيرها.

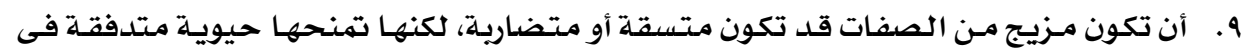

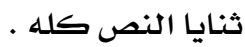

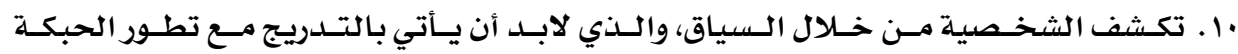
والأحداث.

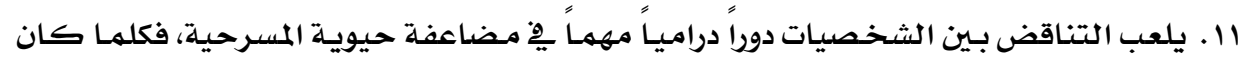

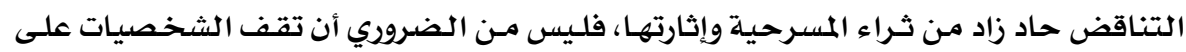

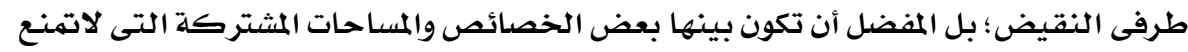

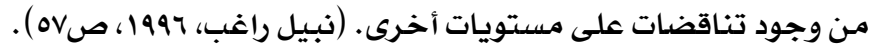

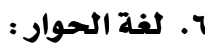

يعتبر الحـوار مـن العناصـر الأسـاسـية فـى بنـاء المسـرحية، إذ ترتكـز عليـه كـل العناصـر

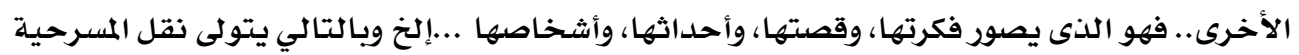

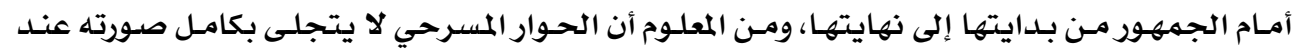

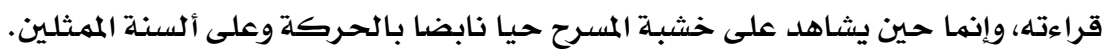

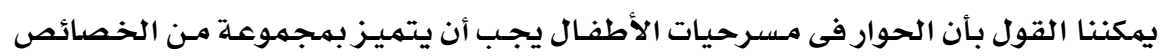
منها: يعتمـد على الإيحـاء والتركيز، فلا نكتب إلا العبـارات الضرورية،، ونستبعد العبـارات التي لا

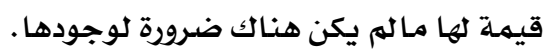

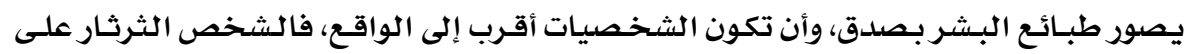
سبيل المثال ينبغي أن يظهر على حقيقته الئه. يفضل أن يكون ذا مسحة أدبيـة أو شـاعريـة؛ بشرط حقية أن تكون صـادرة عن الشخصئهيات مـن غير افتعال. يساعد على تطوير الأحداث نحو العقدة .

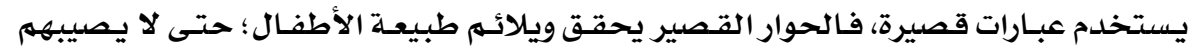

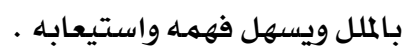

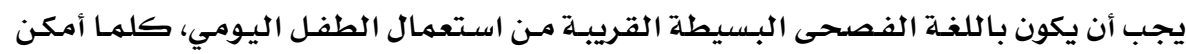

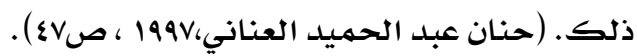

V. الخاتمة :

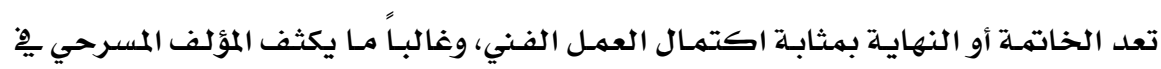

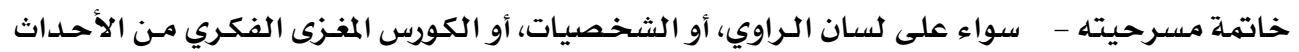

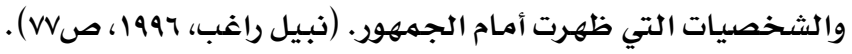




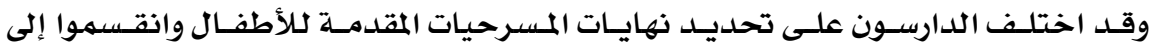

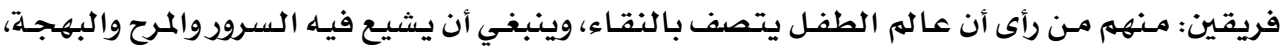

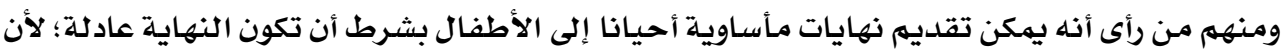

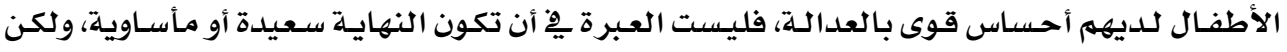

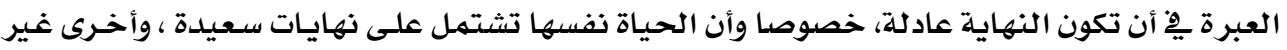

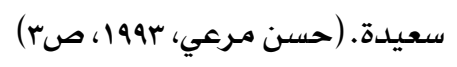

الخلاصة:

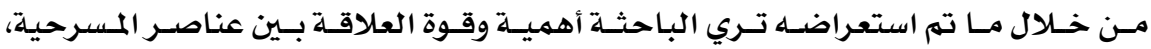

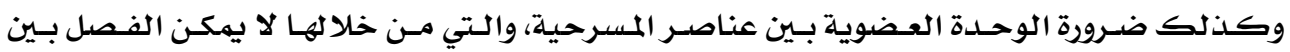

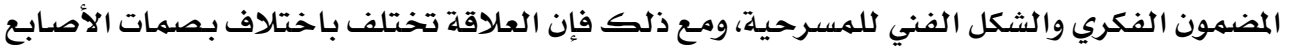

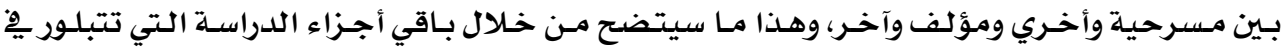
التالي.

\section{الإجراءات المنهجية للدراسة :}

\section{نوع اللدراسة :}

تنتهى هذه الدراسـة إلى الدراسـات الوصفية ، التى تهدف إلى تقرير خصائص ظاهرة معينـة

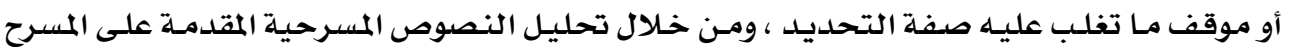

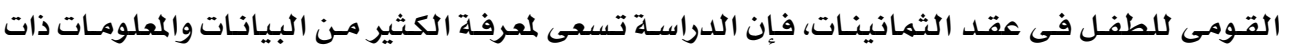

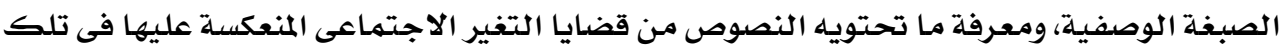

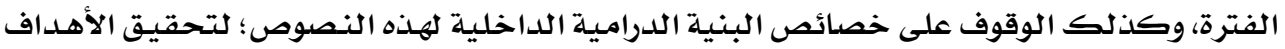

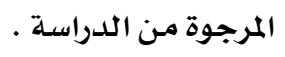

\section{منهج اللدراسة:}

تعتمـد الدراسـة على المنهـج التحليلسى النقـدى الموضـوعى فى تحليـل النصوص المسرحية؛

$$
\begin{aligned}
& \text { باعتباره أنسب المناهـج لهذه الدراسـة . } \\
& \text { عينة الدراسة: } \\
& \text { أولا : عينة المسرحيات: }
\end{aligned}
$$

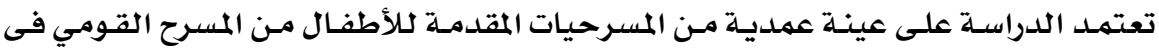

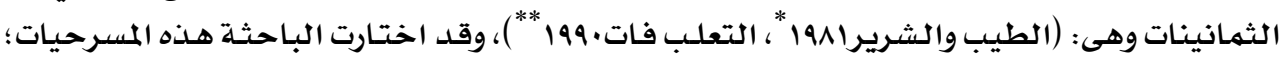

* مسرحية الطيب والشرير تأليف: كامل أيوب، استعراضات: عادل عمر عفيفي، موسيقى: جمال مال عبد الرحيم، ديكور:

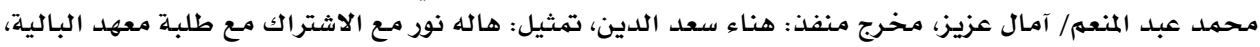

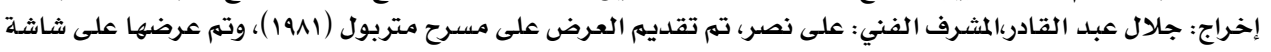

التليفزيون المصرى الخاج الخرى 
كتمثيلها فترات زمنية مختلفة وفاصلة فى تاريخ عقد الثمانينات؛ فالأولى تمثل بداية العقد والأخرى

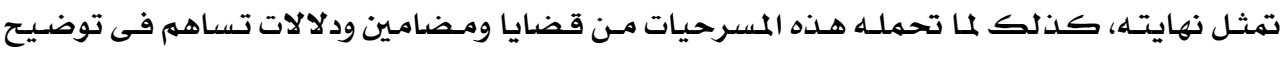

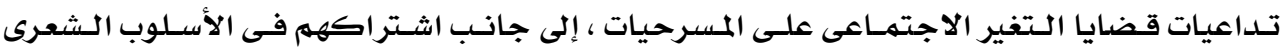

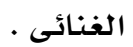

\section{أدوات جمع البيانات : البات}

سيتهم الاعتماد على أداة تحليل مضمون قضايا التغير الاجتمـاعى ، فى النصوص المعروضـة

$$
\text { على المسرح القومى للطفل فى فترة الثمانينات }
$$

\section{تصميم استمارة تحليل المحتوى :}

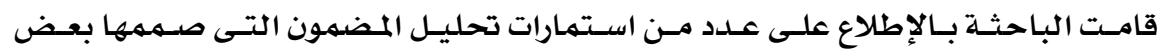

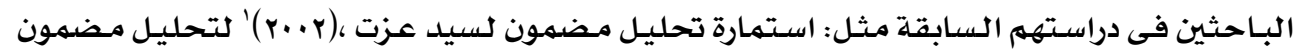

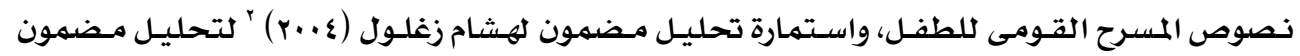

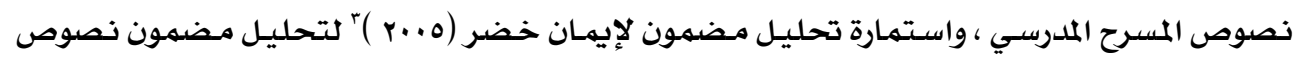

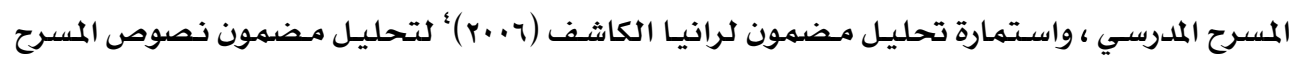

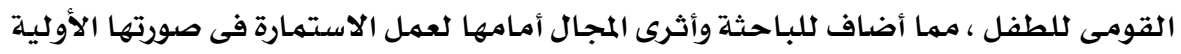

\section{تصمييم استمارة تحليل المحتوى :}

قامت الباحثـة بإعداد وحسدات وتقسيمات رئيسية وفرعيـة لعناصـر النص المسرحى وقضايا

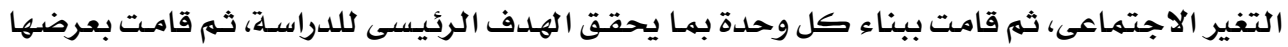

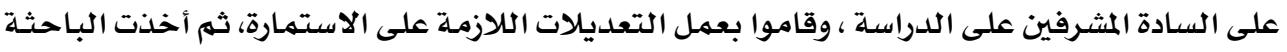

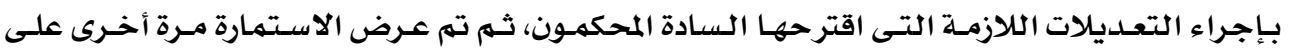
السادة المشرفين بعد تحكيمها وتعديلها حتى أصبحت التحلى في صورتها النها النهائية .

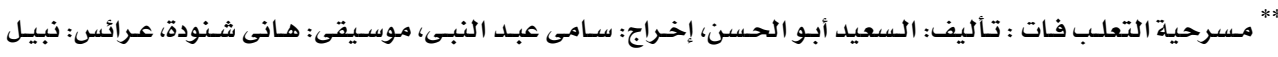

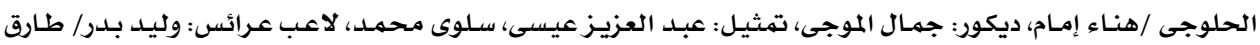

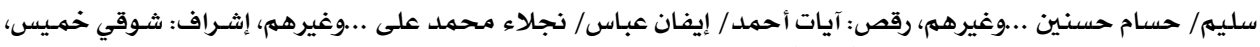

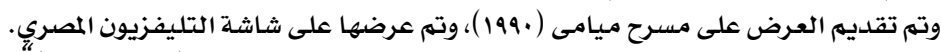

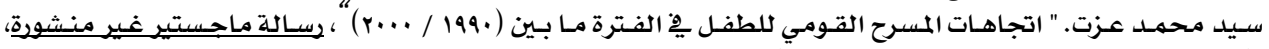

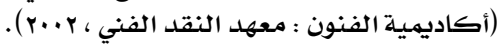

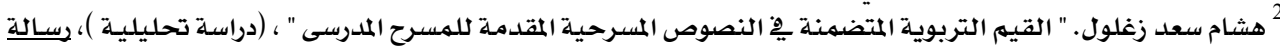

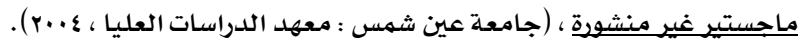

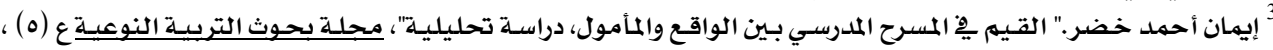

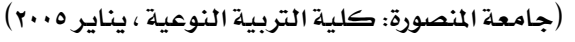

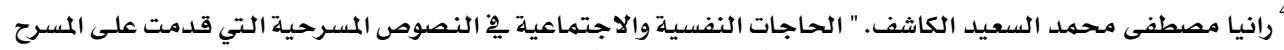

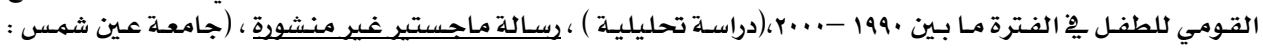

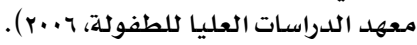




$$
\begin{aligned}
& \text { تحليد فئات تحليل المضموز : } \\
& \text { أولا : فئات الشكل (كيف قيل \&) : }
\end{aligned}
$$

وهى فئات تختص بالتوصيف العام للشكل الذي طبعت بـه المسرحيات ، وتنقسم هـذه الفئكات

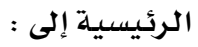

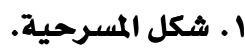

$$
\text { - - }
$$

-

-

-

- مزيج بين القديم والمعاصر

- - - -

- - مكان آخر - -

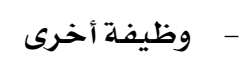

- مصدر آخر

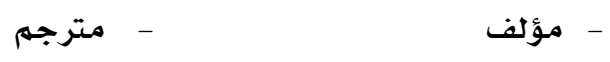

r. البعد الثاني : عدد صفحات المسرحية . r. البعد الثالث : عدد مشاهد المسرحية .

$$
\text { ع. - مشهل. - منس البرابع :عدد المناظر المسرحية - مشهدين. }
$$

ه. البعد الخامس : الإطار الزمني كلأحداث.

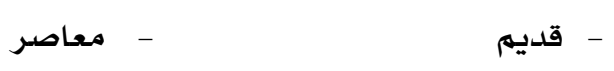

$$
\text { - - إطار آخر - - }
$$

7. البعد السادس : الوظيفة الدرامية للإطار الزمنى للأحداث

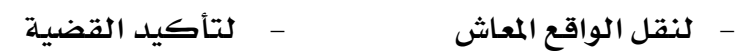

$$
\begin{aligned}
& \text { V. البعد السابع : الإطار المكاني للأحداث. }
\end{aligned}
$$

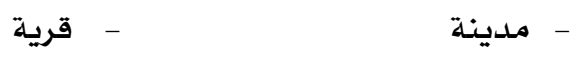

$$
\begin{aligned}
& \text { 1. البعد الثامن: الوظيفة الدرامية للإطار المكانى كلأحداث }
\end{aligned}
$$

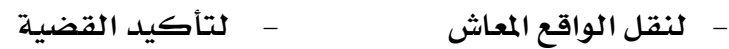

$$
\begin{aligned}
& \text { ثانياً: فئات تحليل (المضمون) ماذا قيل \& } \\
& \text { وهى فئات ترتبط بمضمون ومحتوى المسرحيات. } \\
& \text { وتنقسم هذه الفئات الرئيسية الى : } \\
& 9 \text { ـ البعد التاسع: مصدر الفكرة. }
\end{aligned}
$$

• ا ـ البعد العاشر : نوع قضايا التغير الاجتماعى المنعكسة على اختيار الفكرة . - مضايا قومية - مضايا دولية 


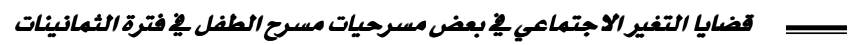

11 البعد الحادي عشر : نوع القضية المثارة بالنص

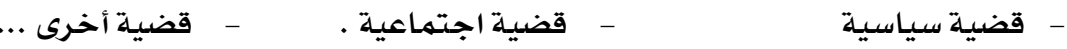

ا ا ـ البعد الثاني عشر: نوع قضايا التغير الاجتماعى المنعكسة على اختيار القضية

- قضايا قومية -

-

-

- قضية أخرى - (... -

rا ـ البعد الثالث عشر : نوع الحبكة .

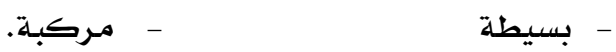

ع ا ـ البعد الرابع عشر: منطقية الحبكة .

حبكة أخرى ...

حبكة غير منطقية

- مبكة منطقية -

10 ـ البعد الخامس عشر: الأسلوب المستخلم فى بناء حبكة المسرحية

$$
\text { - }
$$

17 ـ البعد السادس عشر : نوع الشخصيات التى ظهرت فى المضمون :

- - -

-

- بشريـة -

IV ـ البعد السابع عشر : نوع المهن التى ظهرت فى المضمون:

- مهنة أخرى - مهن

-

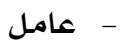

11 ـ البعد الثامن عشر : الطبقة التي تنتمي إليها الشخصيات:

- - مبقة أخرى - -

$$
\text { أرستقراطية }
$$

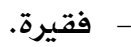

19 ـ البعد التاسع عشر : شكل المعالجة الدرامية على الشحصيات.

- نقل الشخصية الأصلية دون تعديل عدل الشخصية الأصلية لتناسب الواقع المعاش

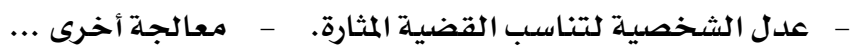

. . . البعد العشرون: نوع قضايا التغير الاجتماعى المنعكسة على الشخصيات .

- مولية

ا ا ـ البعد الحادي والعشرون : نوع الصراع.

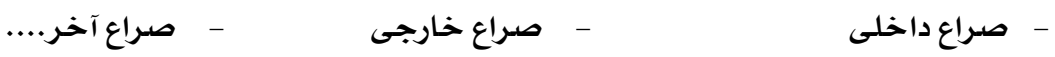

r. r. البعد الثاني والعشرون: الوظيفة الدرامية للصراع.

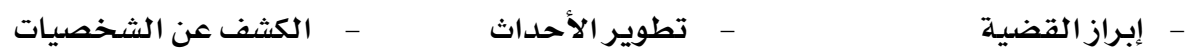

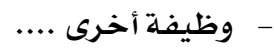




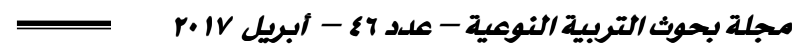

rr ـ البعد الثالث والعشرون : اللغة المستخدمة فى تقديم المضمون :

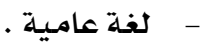

- لغة مربية فصحى مبسطة.

مزيج بين الفصحى والعامية .

ع . البعد الرابع والعشرون: الأسلوب المستخدم فى المضمون:

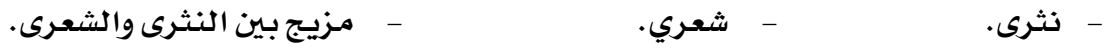

0ץ. البعد الخامس والعشرون : الفكاهة والمرح التى يثيرها الحوار :

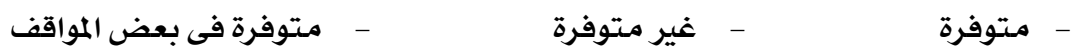

جr. البعد السادس والعشرون: نوع قضايا التغير الاجتماعى المنعكسة على الحوار :

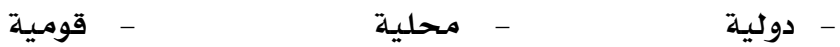

VV

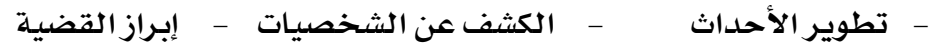

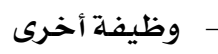

Y . . البعد الثامن والعشرون : أساليب الثواب والعقاب ٍِِ المسرحية.

- متوفرة في بعض المواقف.

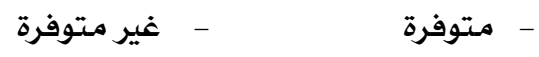

9. . البعد التاسع والعشرون: نوع النهاية.

نهاية غير عادلة

- نهاية عادلة - ن

•r. البعد الثلاثون : شكل المعالجة الدرامية على النهاية.

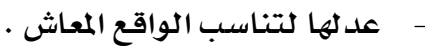
- نقل - نقل النهاية دون تعديل -

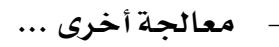

- عدلها لتناسب القضية المثارة.

إجراءات الصدق والثبات لاستمارة تحليل المضمون :

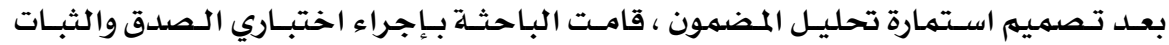

للتأكد من صلاحية الاستمارة للتطبيق وذلك على النحو التالي : 


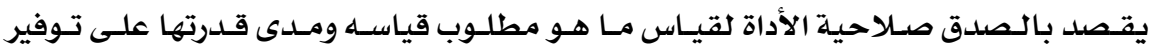

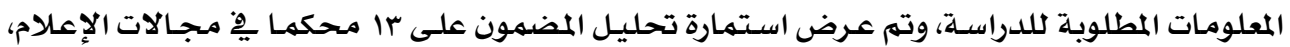

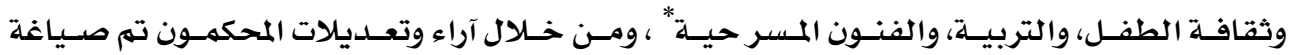

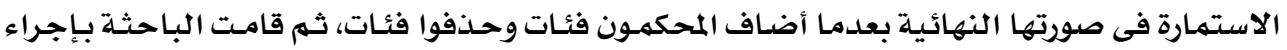

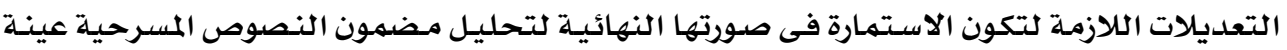

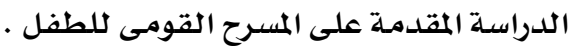

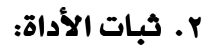

ولحسـاب معامل الثبات بين المحللين قام اثنين من المحللـين بمعاونـة الباحثة فى إجـراءات ثبـات

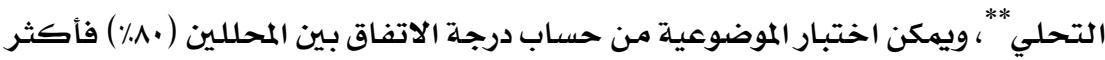

وقامت الباحثة بإجراء ثبات الباحثة مـع نفسها أولا على عينـة مـن النصوص المسرحية المقدمسة

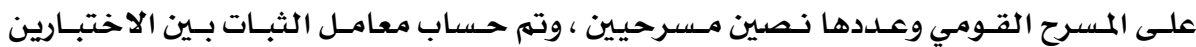

كالتالي على

أ سمهاء السادة المحكمـين مرتبة ترتيبـا أبجديا

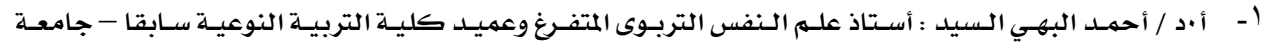

أمنصورة أند أحمارة

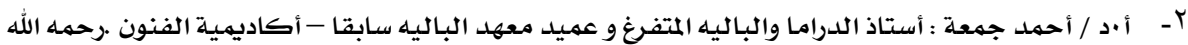

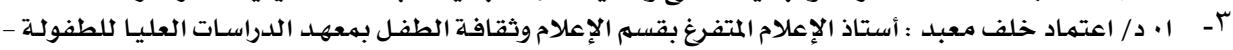

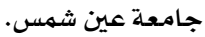

ع- أ·م·د / أمـين السعيد : أستاذ الإعلام المساعد ورئيس قسهم الإعلام سابقا بكلية التربية النوعية- جامعة المنصورة.

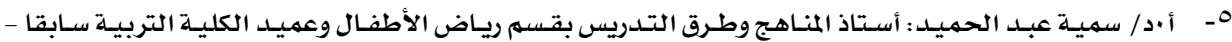

جامعة المنصورة.

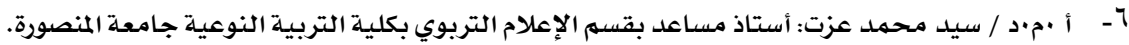

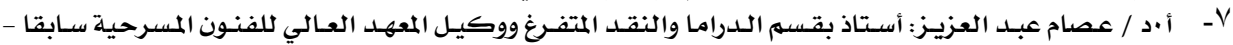

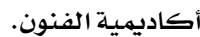

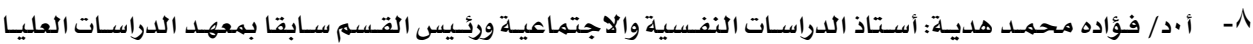

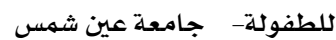

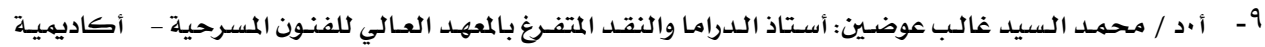

الفنون.

• 1 - أ ـ د / محمد معوض: أستاذ الإعلام المتفرغ ووكيل معهد الدراسـات العليا للطفولة سابقا - جامعة عين شمس.

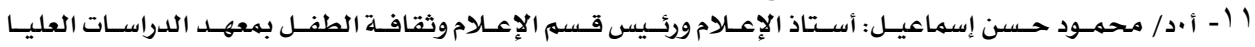

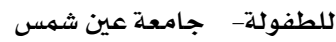

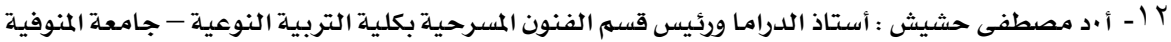

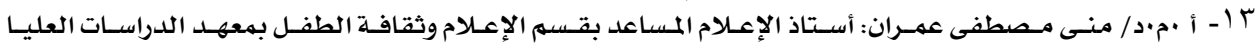

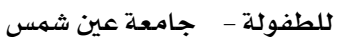

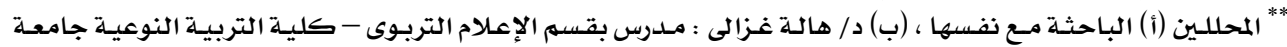

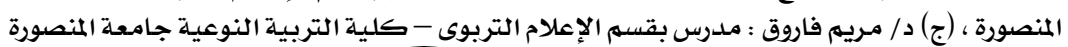


مجلة بحوث التربية النوعية - علد 7 ع - أبريل r.IV

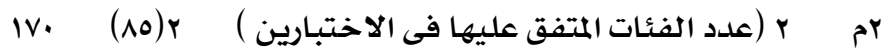

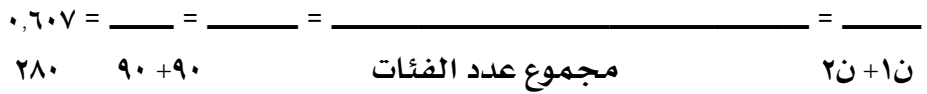

وهـى نـسبـة تــل على ثبـات التحليـل والوثـوق بـنتائجسه، أمـا عـن ثبـات تحليـل البـاحثـة مـع

المحللـين الآخـرين ،فقـد أجـريـت اختبـار الثبـات مـع المحللـين بـالإضـافة إلى البـاحثـة بعـد الاتفـاق على أسســ وإجـراءاتـه، وبعـدمـا قامـت البـاحثـة بشـرح إجـراءات التحليـل لفئـات التحليـل ووحداتـه، تم إجـراء التحليل على عينه من النصوص المسرحية المقدمة على المسرح القومى وقوامها نصين مسرحين ويرمـز للمهحللـين بـادرموز : (أ) الباحثـة نفـسها ، (ب) المحلـل الأول ، (ج ) المحلـل الثـانى . وبذلك تكون معاملات الثبات كالتالى :

$$
\begin{aligned}
& \text { IV. }(10) r \\
& \text {., } q \leqslant \varepsilon=\frac{}{11 \cdot}=\frac{}{q \cdot+9 \cdot}=4
\end{aligned}
$$

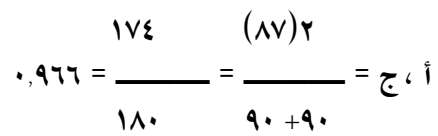

$$
\cdot 9 V V=\frac{1 V 7 \quad}{1 \Lambda \cdot \quad}=\frac{(\Lambda \Lambda)^{r}}{q \cdot+q \cdot}=\tau \cdot
$$

ولحسـاب معامل الثبات بين المحللين سيتم بالمعادلة الآتية :

ن (متتوسط الاتفاق بين المحللين)

$$
\text { 1+ (ن +1+( (متوسط الاتفاق بين المحللين) }
$$

حيث ( ن ) عدد المحللين ، ومتوسط الاتفاق = مجمهوعهم على عددهم

$$
\begin{aligned}
& \text { Y,A V } \quad \cdot, 9 V V+\cdot, 977+\cdot, 9 \varepsilon \varepsilon \\
& \cdot, 97 r=\frac{r}{r}=\frac{}{r}= \\
& .974 \times r
\end{aligned}
$$

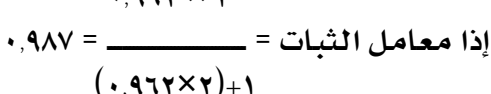

ويتضـح مـن هـذه النتـائج أن عمليـات التحليـل التىى اعتمـدت على اسـتمـارة تحليـل المضمون

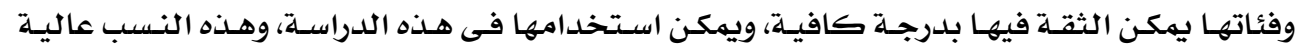
بدرجة يهكن الاعتماد عليها والوثوق بنتائجها 


\section{جراءات تطبيق استمارة تحليل المضمون على المسرحيات عينة الدراسة.}

بعسد الانتهاء مـن إعـداد اسـتمارة تحليـل المضمون فـى صـورتها النهائيسة توجهـت الباحثـة

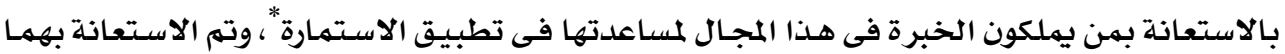

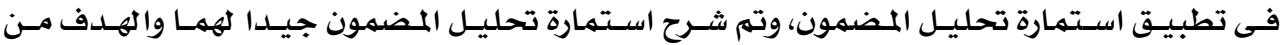

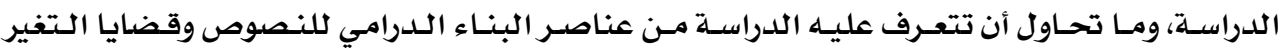
الاجتماعى المنعكسة عليها، كذلك تم شرح وحدات الاستمارة والتعريفات الإجرائية للدراسـة.

\section{نتائج الدراسة:}

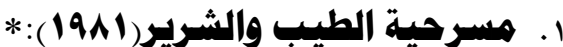

تبين من خلال ملاحظة الباحثه واطلاعها على إعلانات المسرحية فى هذه الفترة فى مجلـة المسرح أن المسرحية كانت تعرض فى فترة حكم الرئيس الراحل محممد أنور السادات، وبعـد استشهاده

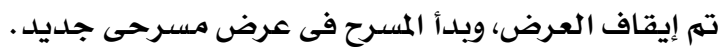
أولا: نتائج الدراسة المتعلقة بالشكل :

المسرحية عبارة عن أوبريت غنائي يتناول موضوعا جادا ، مكونه من فصل واحدل، وقد اشتمل

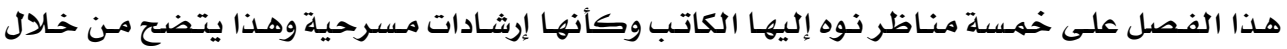
التالى :

الأول: منظر القهوة (الطيب يستمر فى المشى تحت ظلال الضوء الخافت جدا ..إلى أن ترى قهوة

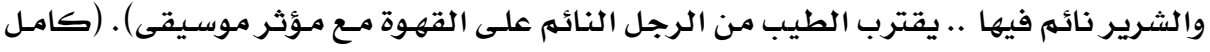

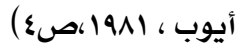
• الثانى: منظر الصحراء ( إضاءة خافته على بقايا مدينة عتيقة مهجورة فى قلب الصحراء، ثم

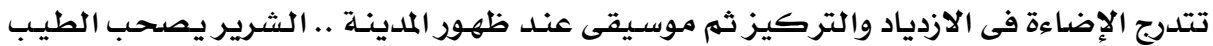

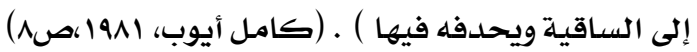

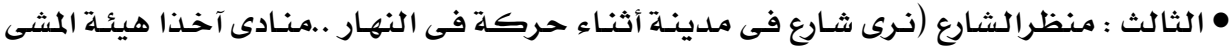

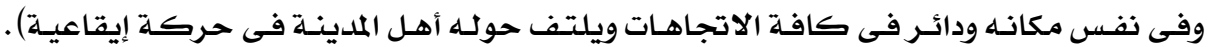

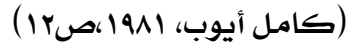

• الرابع: القصر (السلطان سيف الدين وهو يزف شفاء إبنته الأميرة إلى أعوانه وأفراد حاشـيتهـ..

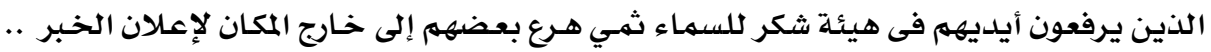

" د / هالة غزالى : المدرس بقسه الإعلام التربوى - كلية التربية النوعية جامعة المنصورة

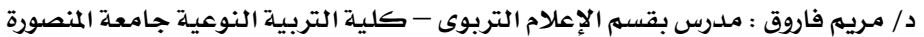

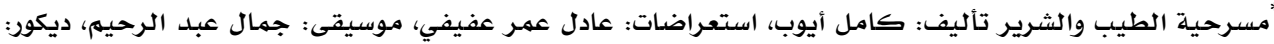

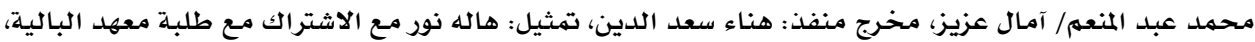

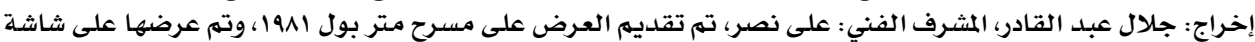

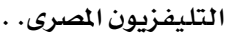




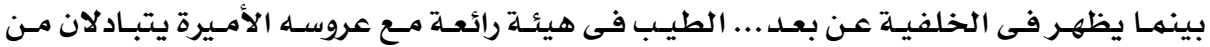

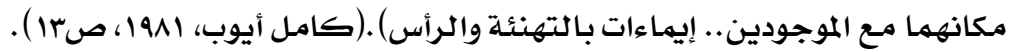

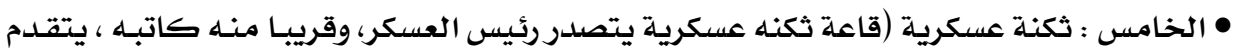

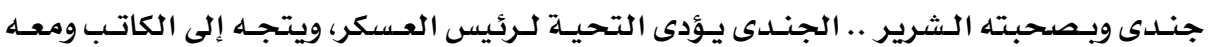

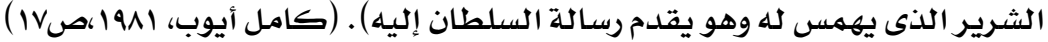

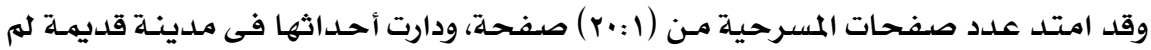

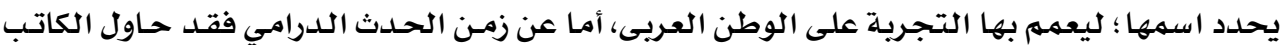

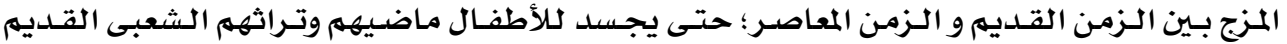

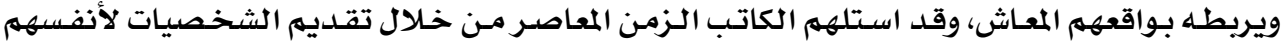

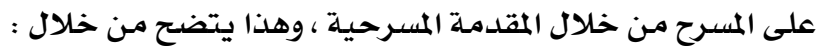
الأميرة : اسهى هيكون من الليلة فوق المسرح نور دا كل اللى قالهولى المؤلف م السرور قال لجل أكون بطبيعتى هنا قدام الجمهور أنا أنا أنا .................بنت السلطان أنا م الأحلام مولوده في الحكايات الشعبية تيجى السنين وتروح و أنا زيى ما نا صبية وحلوة وسنيورة والشاطر هو اللى بيفوزبيه

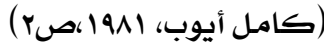

أما الزمن القديم فقد استلهمهـ الكاتب من خلال أحسداث المسرحية ، والتى حـدثت في زمـن

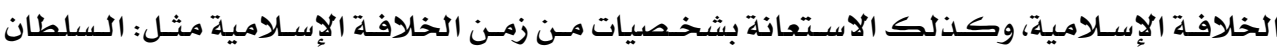

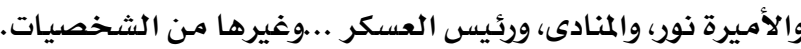

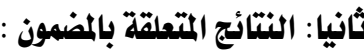
الفكرة الرئيسية للمسرحية:

الفكره الرئيسية التى يدور حولها النص هى : "التعايث السلهى مـع الآخـر " ، ويتفـرع منهـا

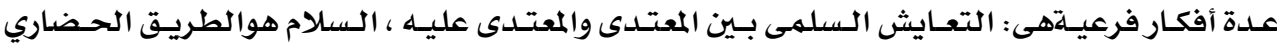

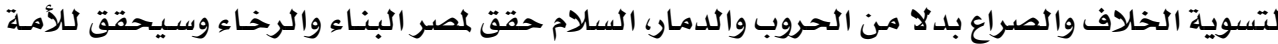

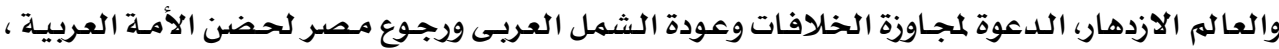

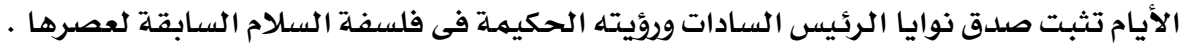




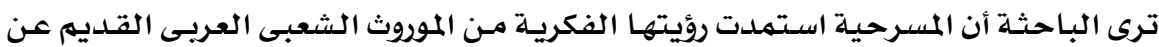

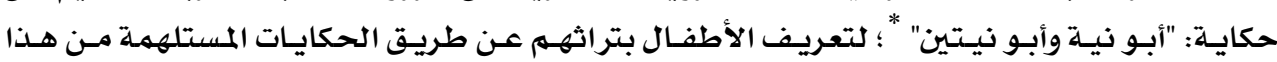

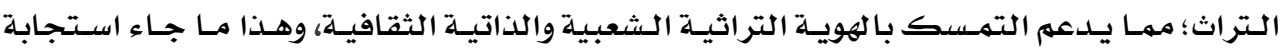
للتوصيات التتالية:

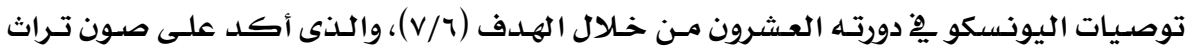

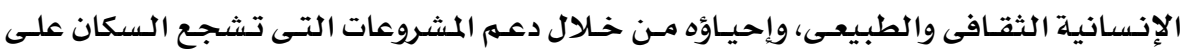

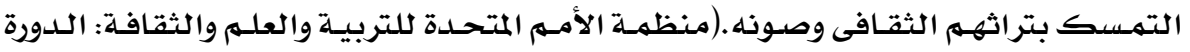

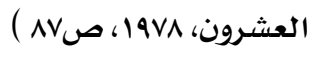

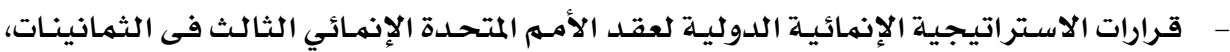

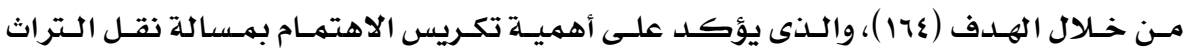

"اطلعت الباحثة على بعض روايات القصة الأصلية - أبو نية وأبونيتين - فوجدتها روايات متنوعة ؛ لأن الرواية الشعبية

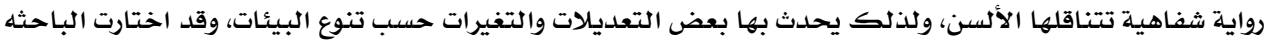

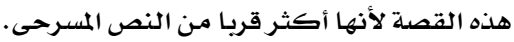

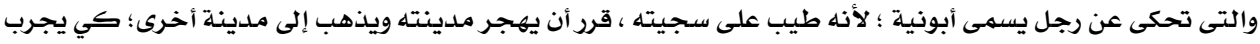

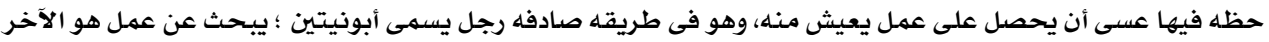

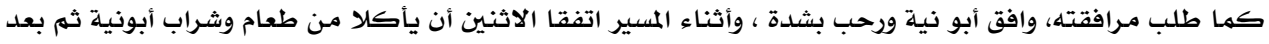

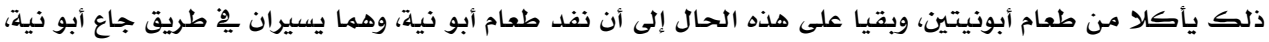

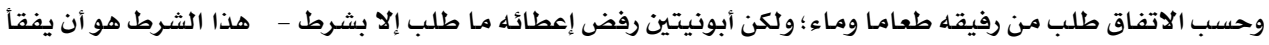

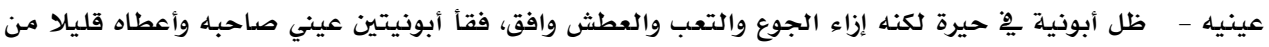

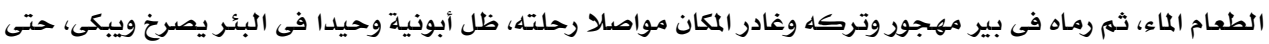

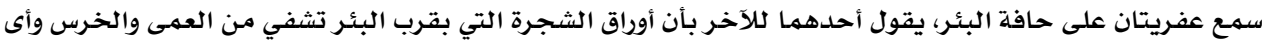

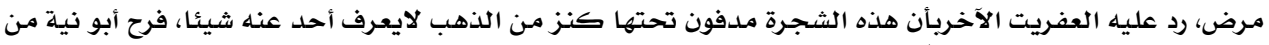

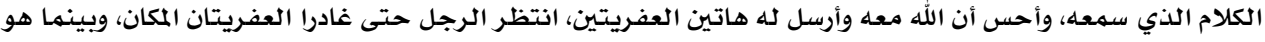

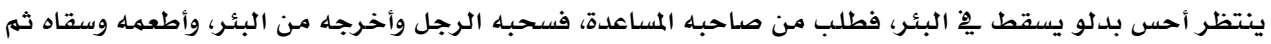

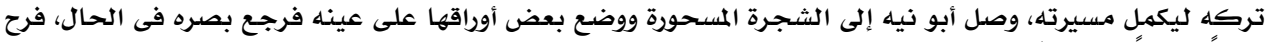

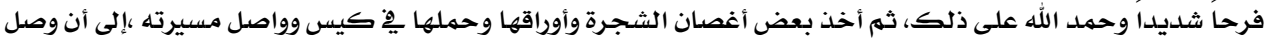

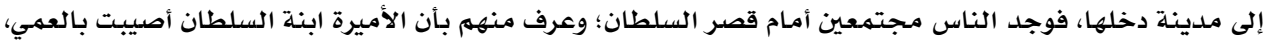

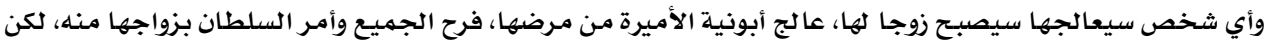

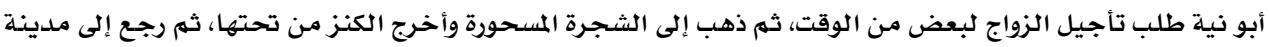

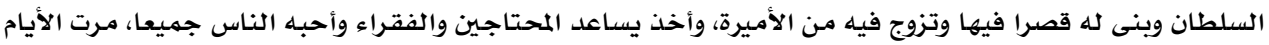

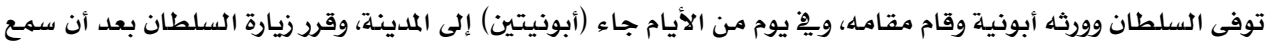

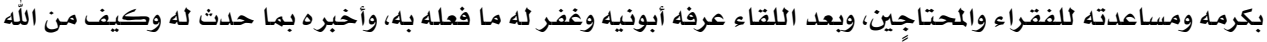

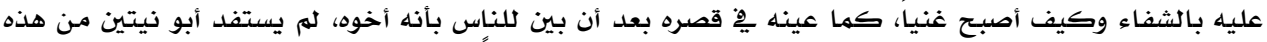

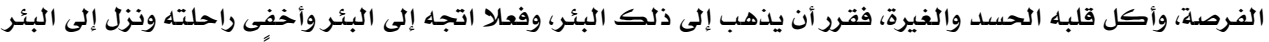

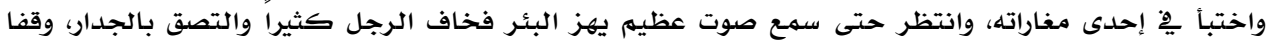

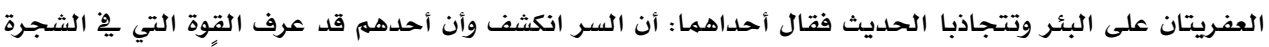

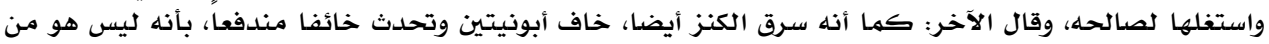

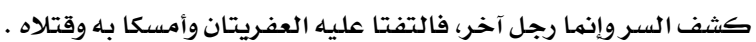


الثقافى والقيهم العامة للجنس البشرى عن طريق التعليهم ـ (الجمعية العامـة للأمسم المتحسدة .

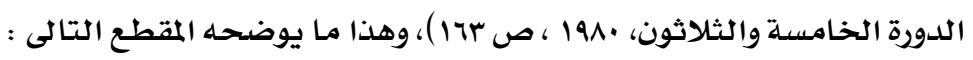
الراوي: يا شجرة الحواديت يا طارحلة شوق وخيال هزي الفروع يالكلا وسمعينا أمال .. يامـا

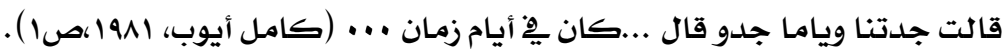
المعالجة الدرامية للمسرحية:

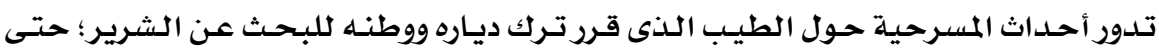

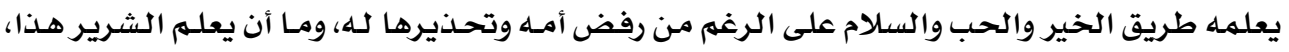

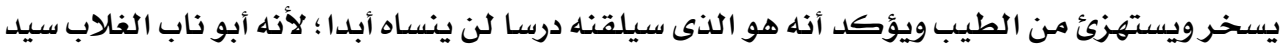

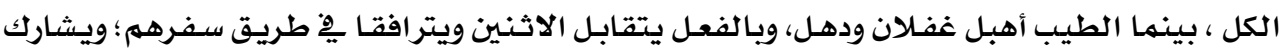

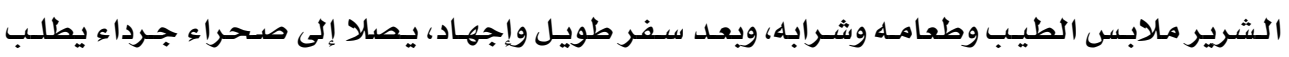

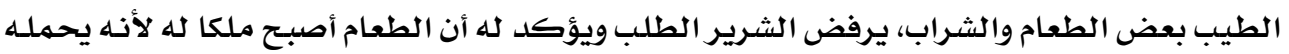

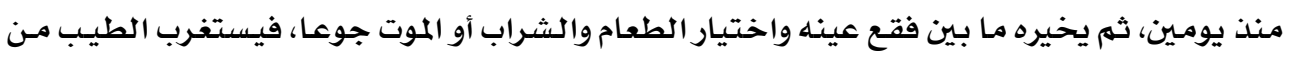

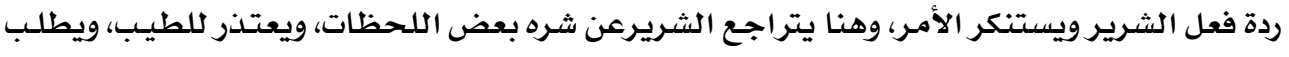

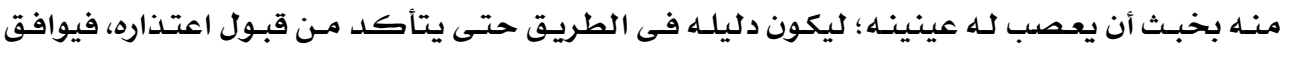

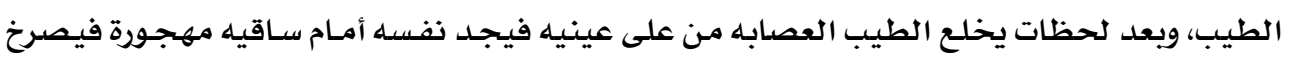

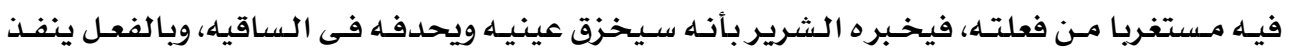

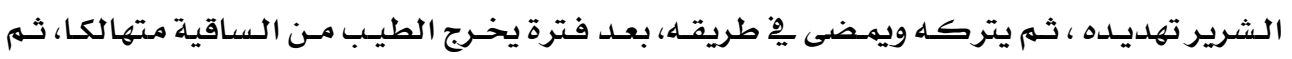

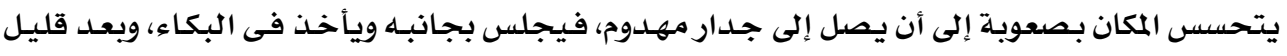

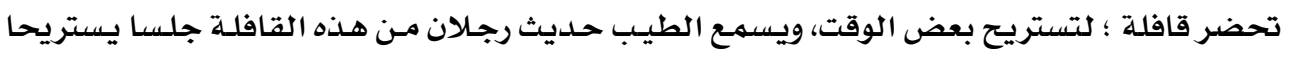

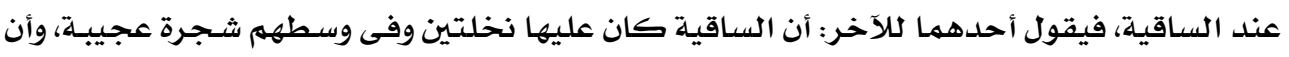

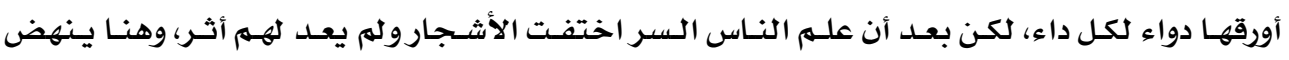

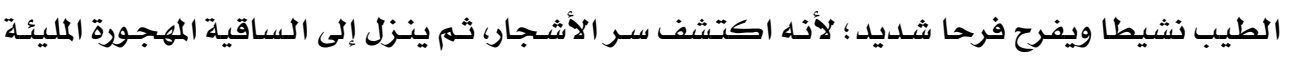

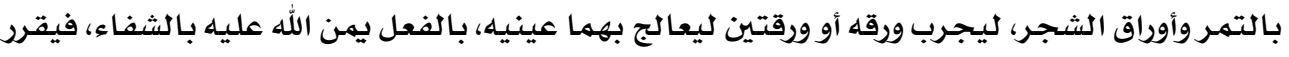

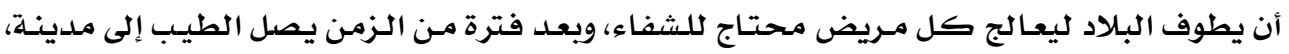

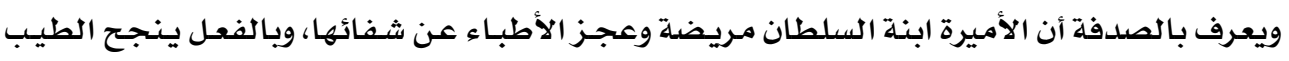

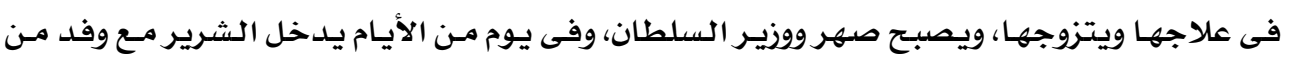

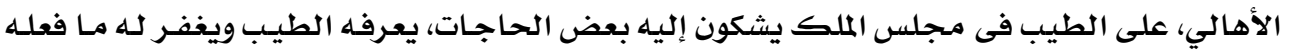

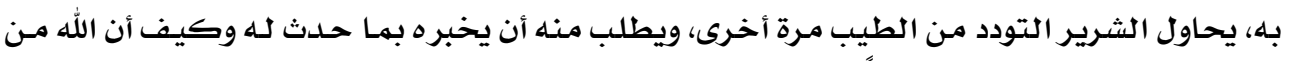

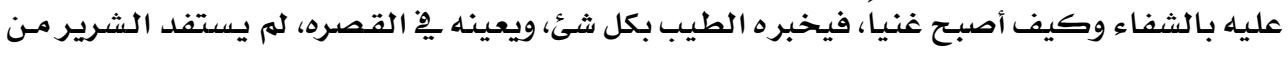

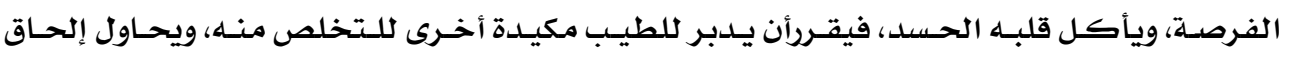

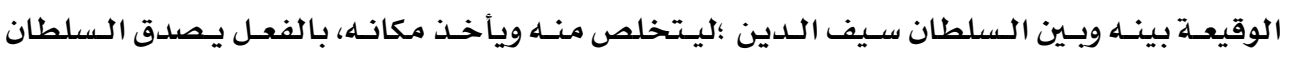

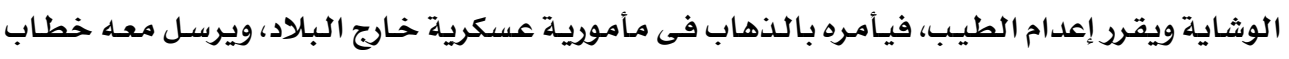




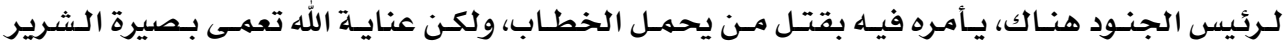

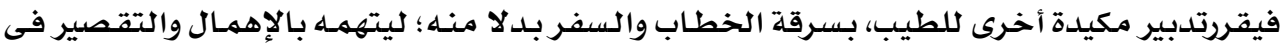

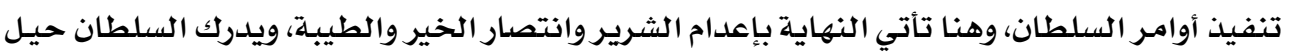

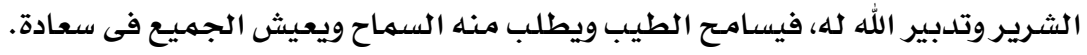

القضية المثارة بالمسرحية:

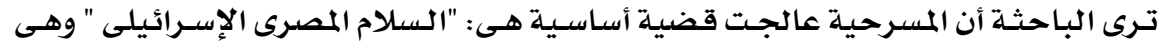

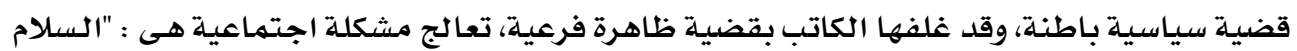

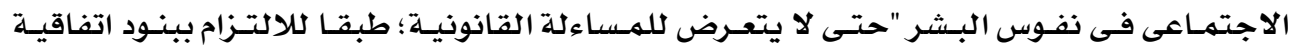

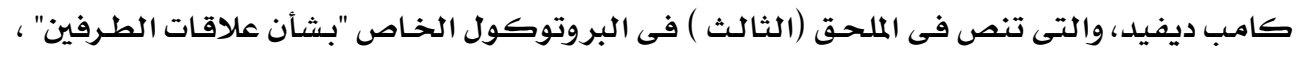

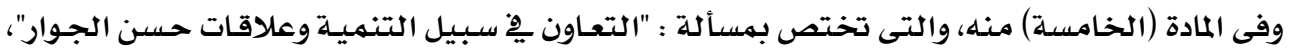

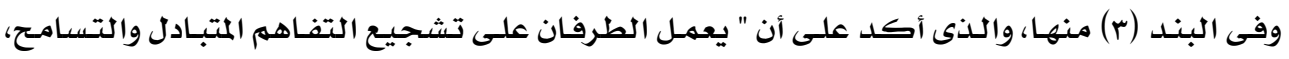

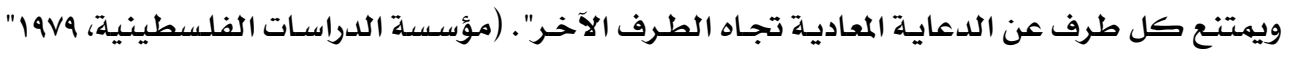

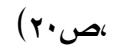

وترى الباحثة أن الكاتب المسرحى استلهم رؤيتـه الفكريـة ؛ نتيجـة استتجابته لعـدة مـتغيرات

وتوجهات كانت موجودة على الساحة فى تلك الفترة وهى البـ كالتالى :

أولا: التوجهات / القضايا المحلية التالية :

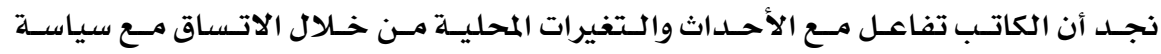

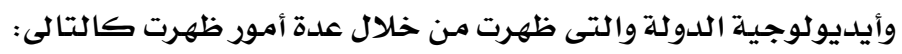

توقيع معاهدة السلام المصرية (19V9) مـع إسـرائيل: قام الكرئيس السـادات برحلته إلى الولايـات

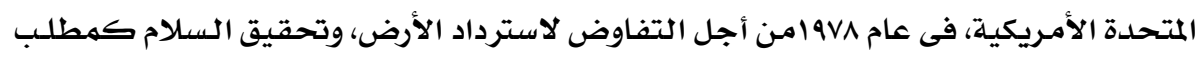

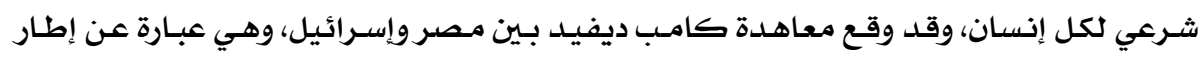

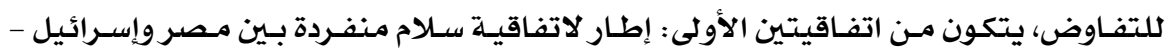

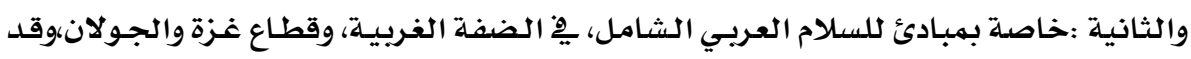

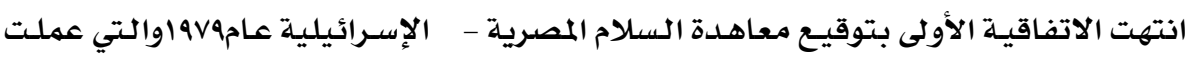

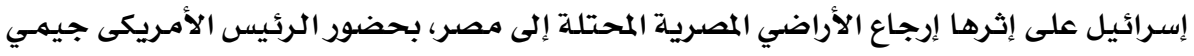

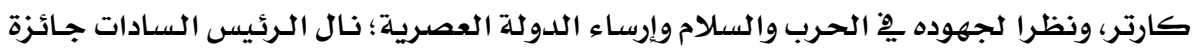

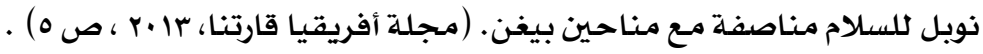

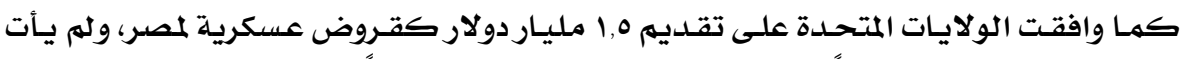

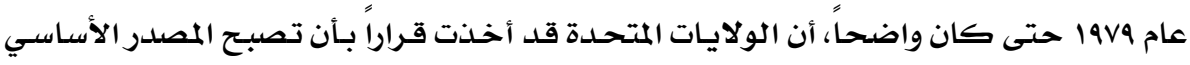

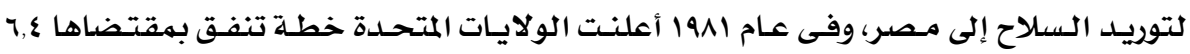

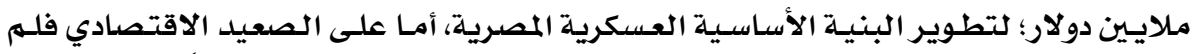

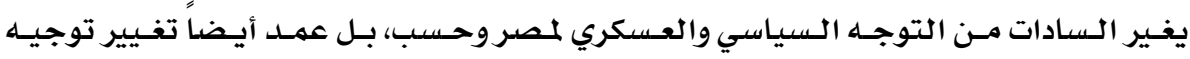




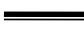

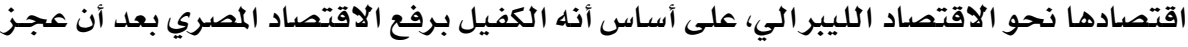

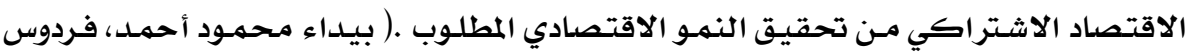

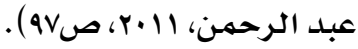

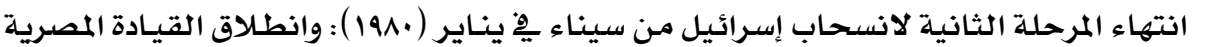

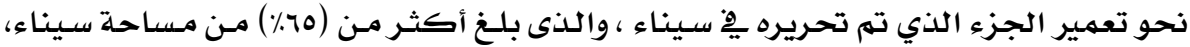

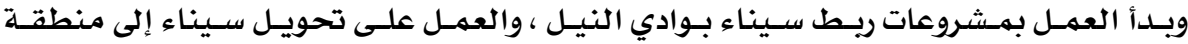

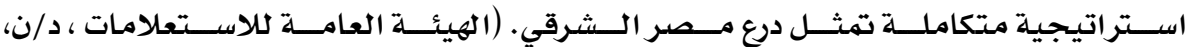
(http://www.sis.gov.eg/section/5243/6779?lang=ar جاءت متسقة مـع السياسة التعليمية للاولة في هـذه الفترة والتى هي جز ء من سياستها العامـة،

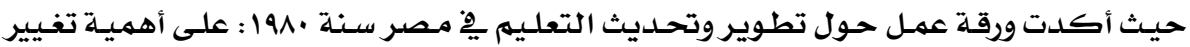

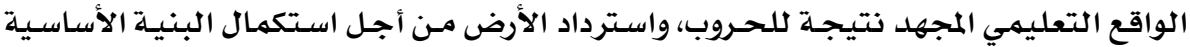

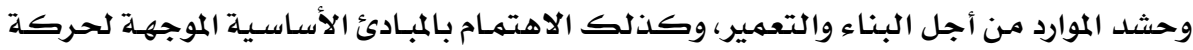

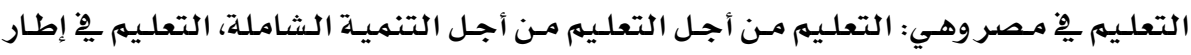

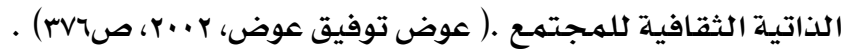

ثانيا : التوجهات /القضايا الدولية الآتية :

نجد أن الكاتب التجأ للنهوذج الغربى والمعونات الدولية المشروطة من خلال الآتى:

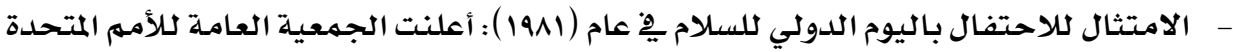

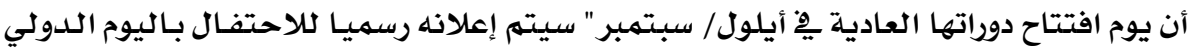

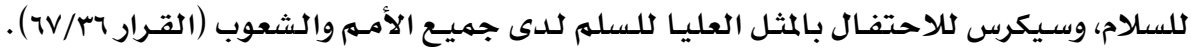

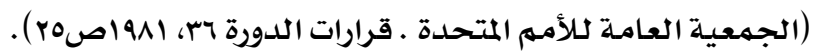

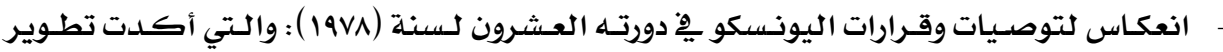

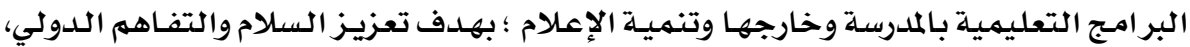

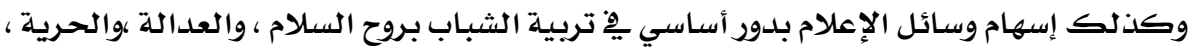

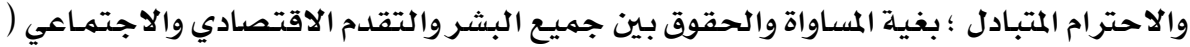

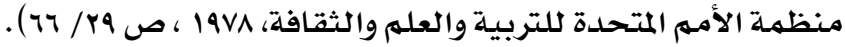

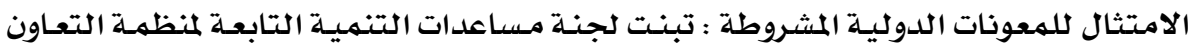

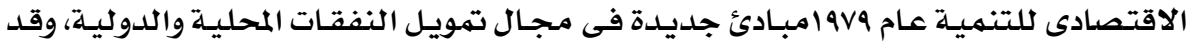

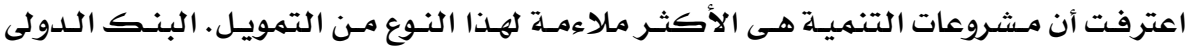

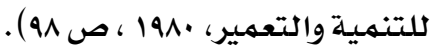

\section{ثالثا : التوجيهات / القضايا القومية التالية :}

ترى الباحثة أن الكاتب تفاعل مـع أحداث الأمـة العربية فى هذه الفترة مـن خلال التالى: 


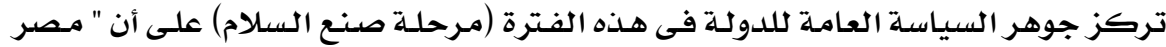

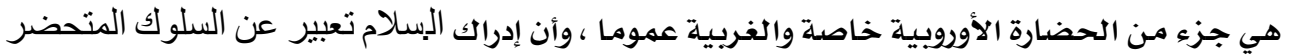

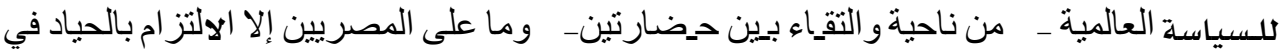

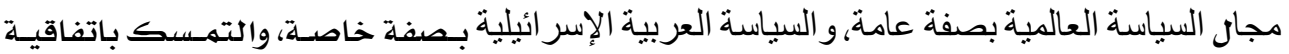

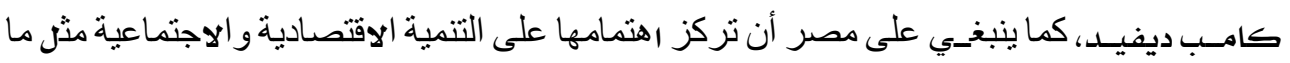

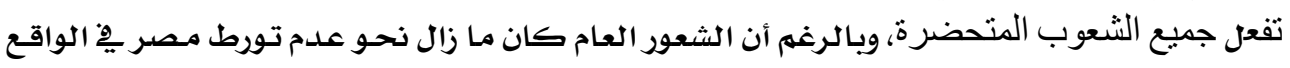

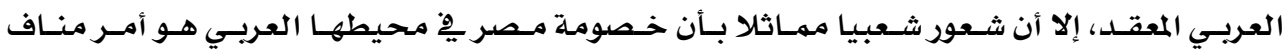

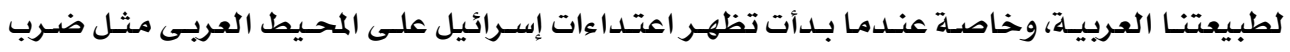

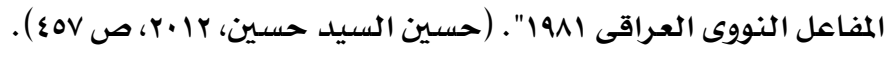

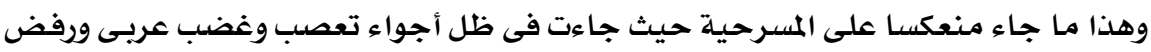

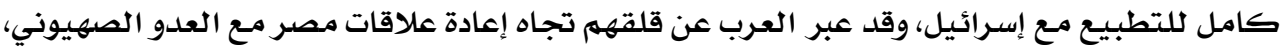

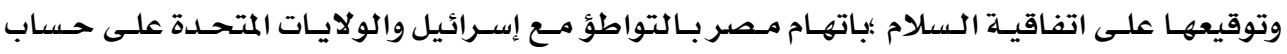

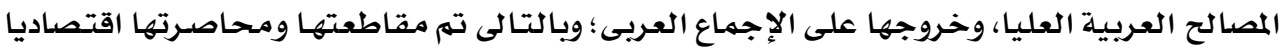

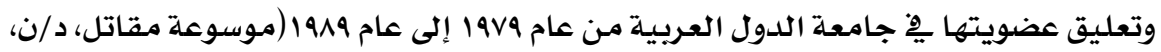
http://www.moqatel.com/openshare/Behoth/Monzmat3/GamaArabi/sec07.doc_cvt.htm

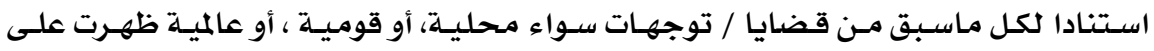

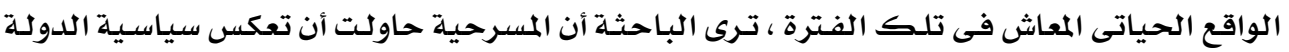

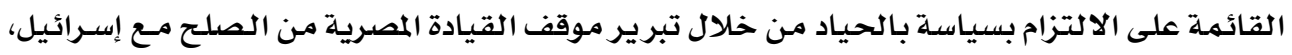

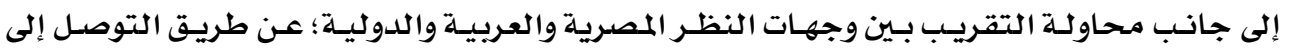

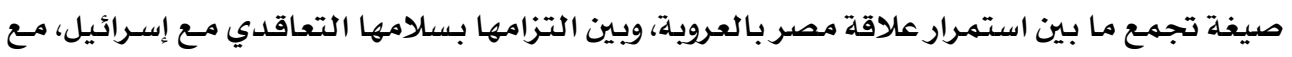

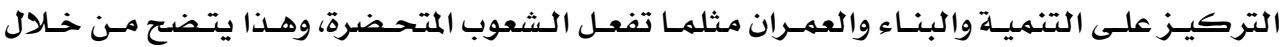

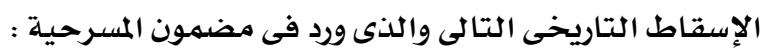

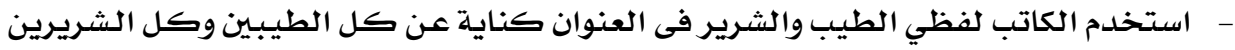

$$
\text { هو إسقاط سياسي على (قائد مصر، قائد إسرائيل). }
$$

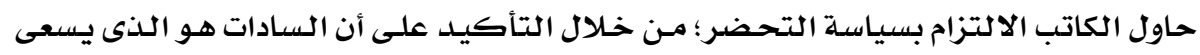

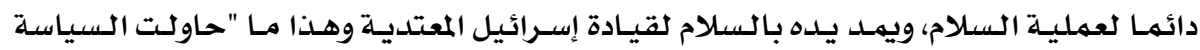

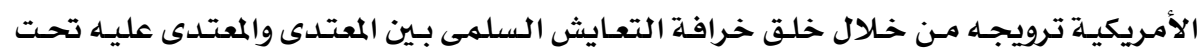

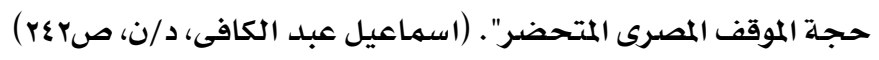

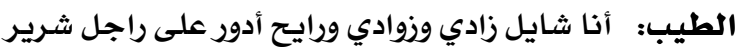

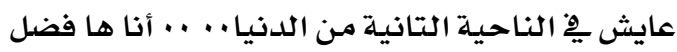

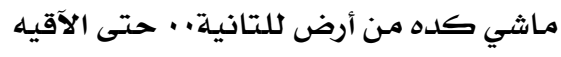

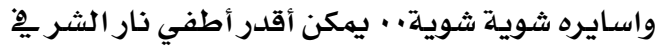

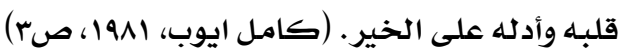


عبر الكاتب عن موقف الدول العربية من قضية السلام ؛ من خلال التقريب بين وجهتى النظر

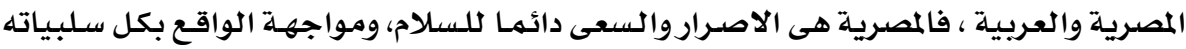

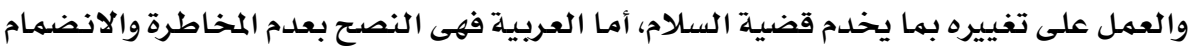

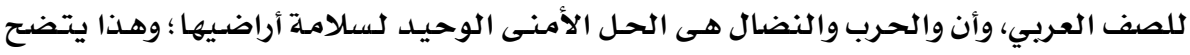

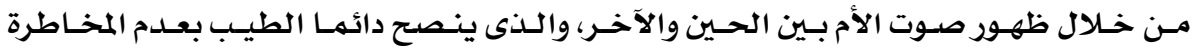

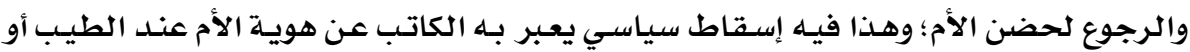

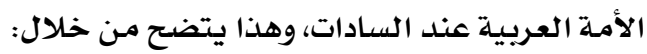

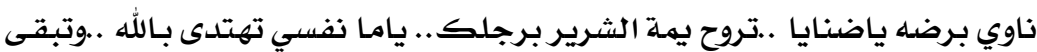

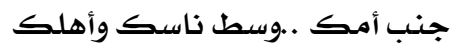

$$
\text { الطيب: انتي يا امـه جوه قلبي... فين أروح طيفك سابقني }
$$

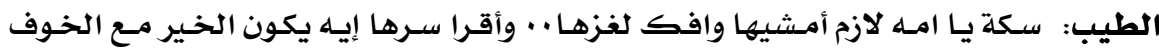

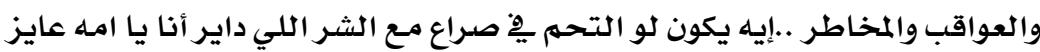

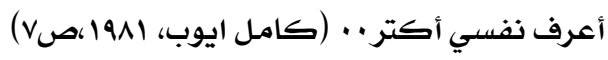

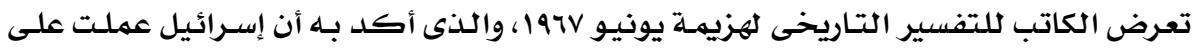

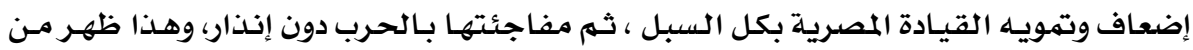

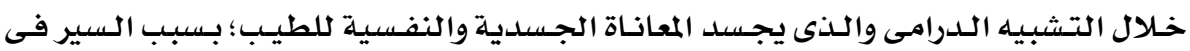

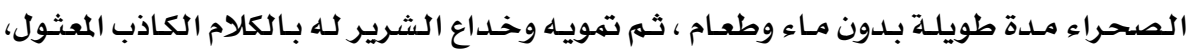

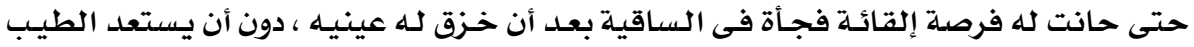
لذلك وهذا يتضح من خلال التالى:

الطيب : هفتان يا صاحبى ومش قادر ( الطيب ناهضا بصعوبة على قدمه ) هفتان جوع وعطث ..والزاد اللى معاك زادى .. الشرير : خلاص الزاد دا مبقاش زادك..أنـا اللى شـايله على كتفى ..ليـه أكثر مـن يومـين

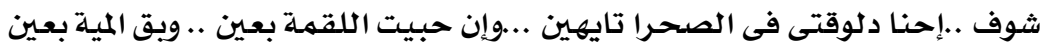
الطيب : وامشى ازاى معاك... وتمشى ازاى معايا ؟ ....

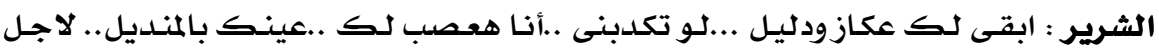
تتأكد إنى عمرى ..مانا مفرط فيك ياكلا ..هه تعالى ..هه ..تعالى يمـين شويـة .. الطيب : (يوقف فجأة ويفتح عينيه يلاقى الساقية قدامه يصرخ) ..ناوى تعمل فيه إيه؟

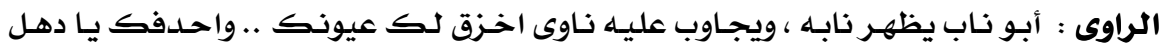

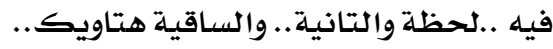


(الشرير يصحب الطيب إلى الساقية ويحدفه فيها مع مؤثر موسيقى بينما الطيب متهالكا

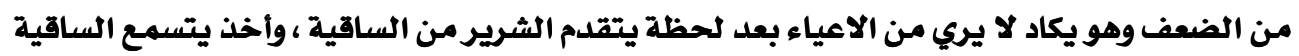

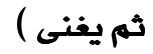

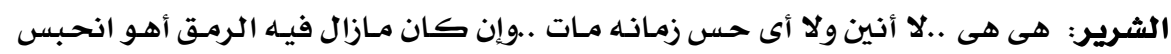

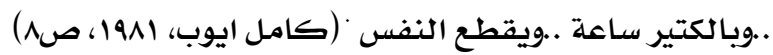

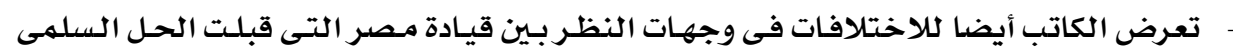

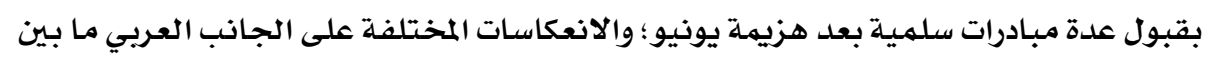

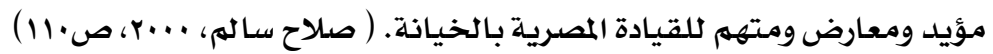

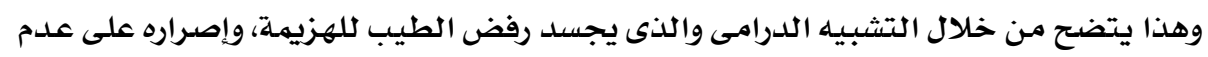

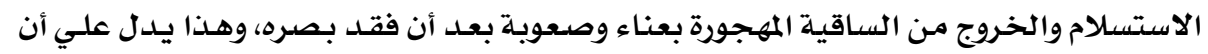

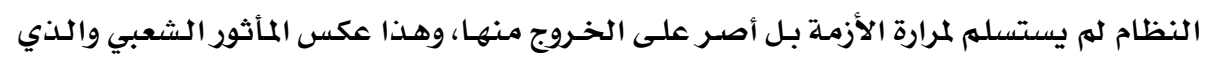

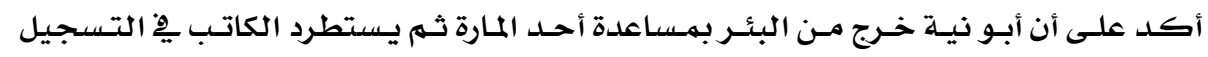

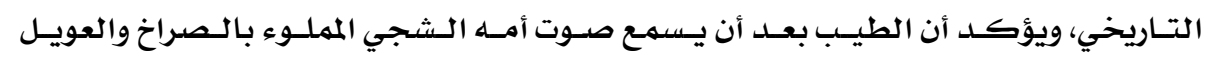

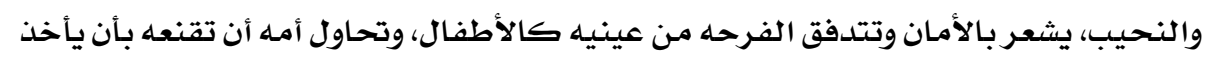

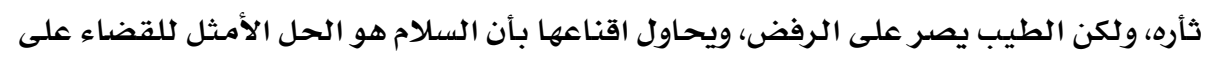

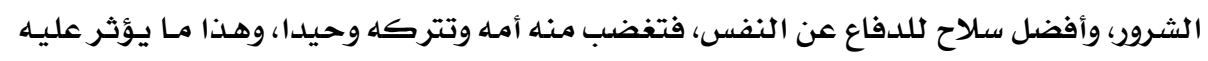
ويجعله ينهار نفسيا ونرى هذا من خلال الآتي:

(إضاءه ثم موسيقى راقصة ...والأطفال يؤدون آهات ذات طابع دينى حول الساقية .. يخرج

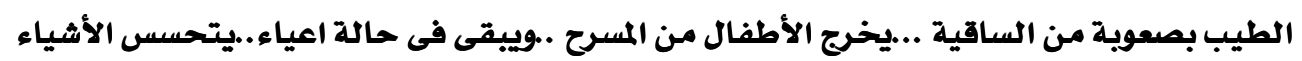

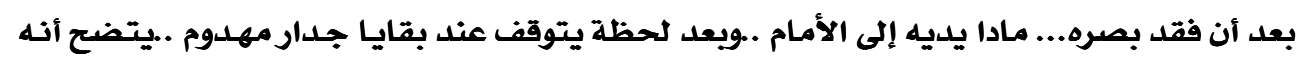

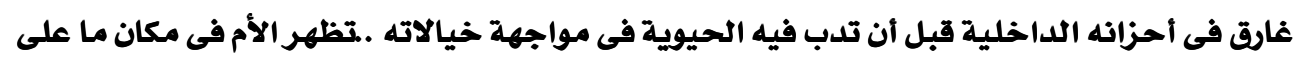

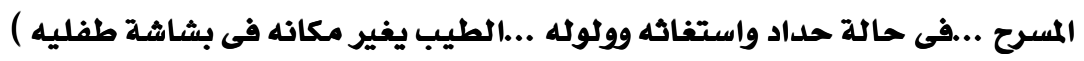

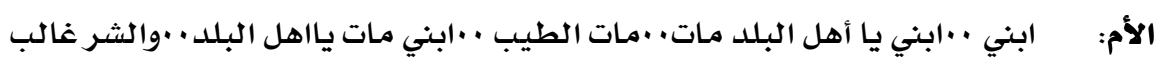

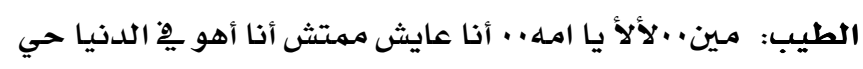

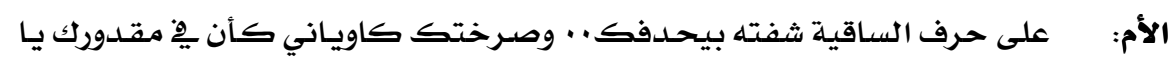

$$
\text { ولدي تحدفه أنت وتنجي }
$$

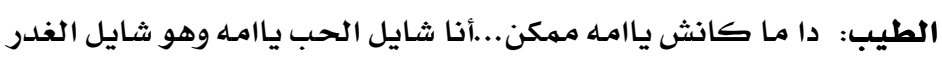

$$
\text { الأم: يعني يا ابني تروح قتيل }
$$

الطيب: يعني ياامـه أحيا قاتل ل·يبقى إيه الفرق بينا هو هادم وأنا باني

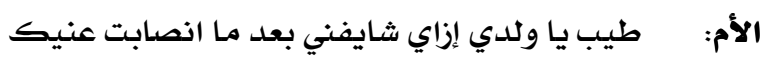


الطيب: متتخافيش على يا امـه لأني أعمي.' جوايا قمر ونجـوم ونوروقت مـا غمضت عيني

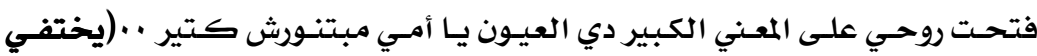

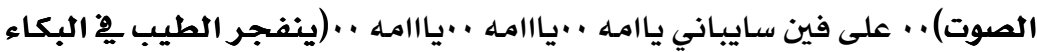

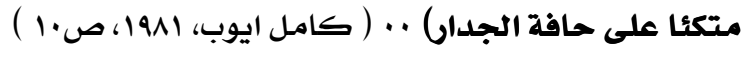

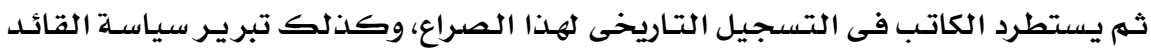

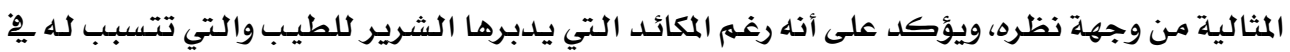

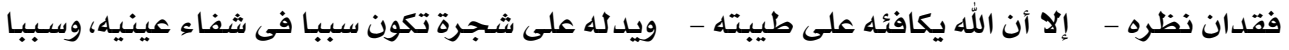

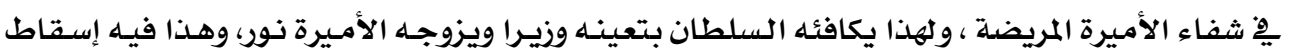

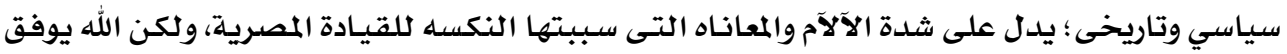

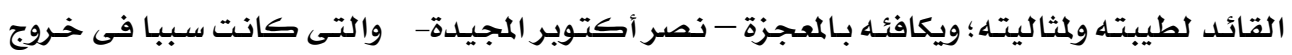

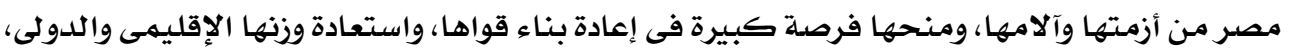

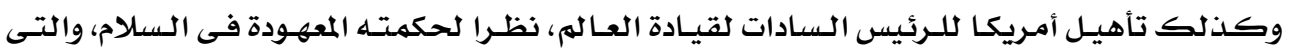

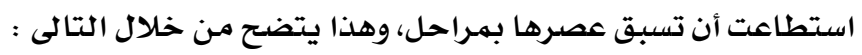

(السلطان سيف الدين وهو يزف شـفاء ابنته الأمـيرة إلى أعوانه وأفراد حاشـيته... الـذين

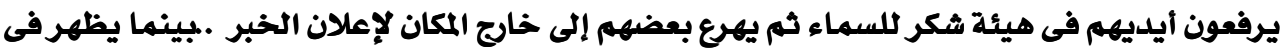

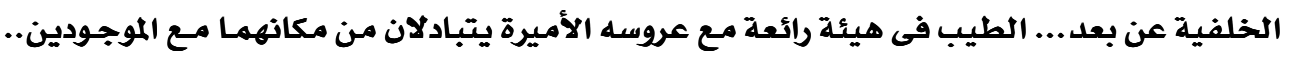

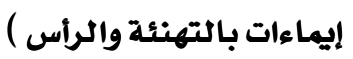

السلطان : يا خدم .. ياحشه .. ياحجاب زفوا البشرى لكل رعيتنا إللى جميعهم أهل وأحباب

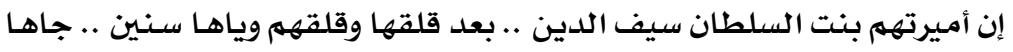

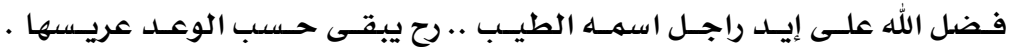

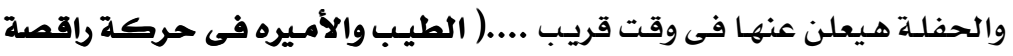

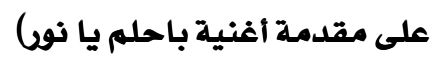

السلطان : زيلدو العطايا وا لهبات .. ومنادى ينادى ويعلن على كل الأبواب .. إن الطيـب مـن

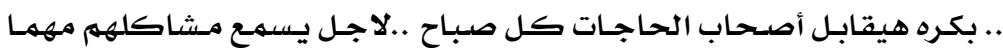

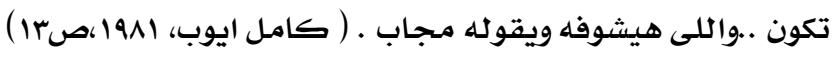

ثم يمضى الكاتب فى انحيازه وتبريره لسياسـة الرئيس الراحل السـادت، ولا يكتفى بهـذا بـل

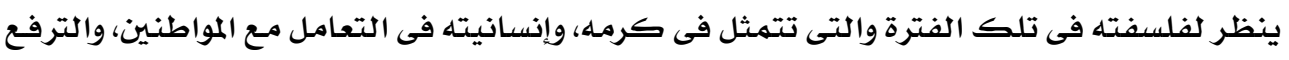

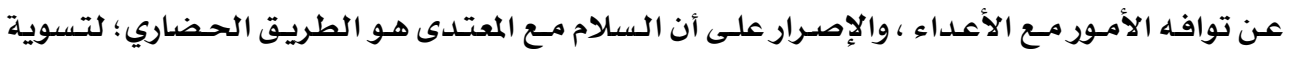

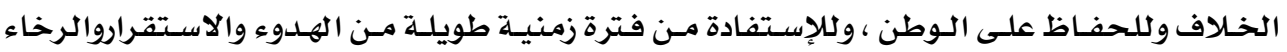

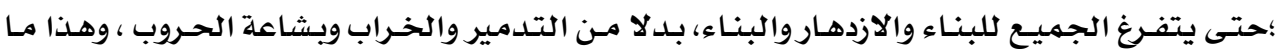
يصوره لنا الحوار التالى : 


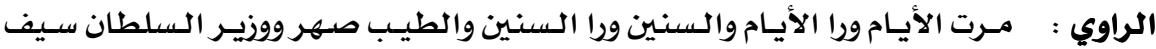

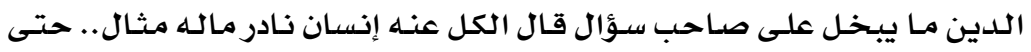

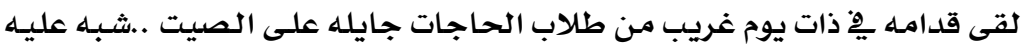

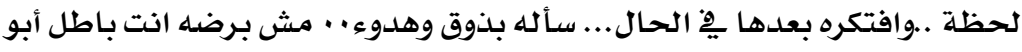

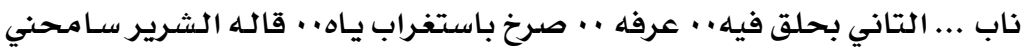

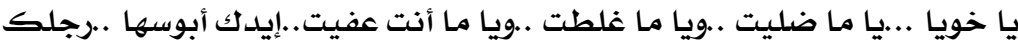

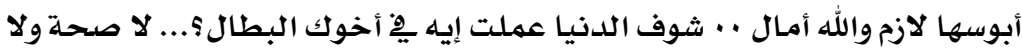

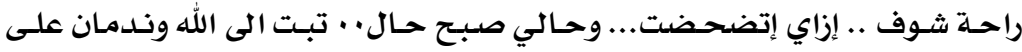

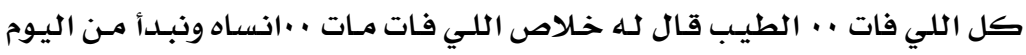

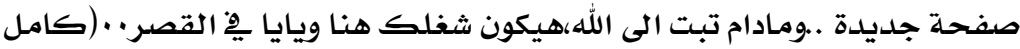

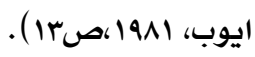

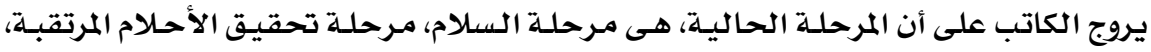

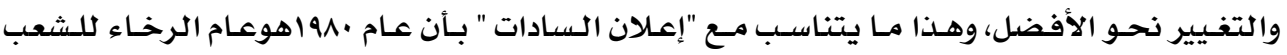

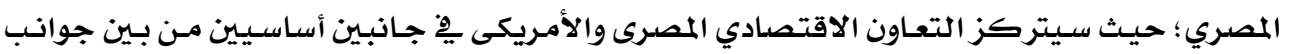

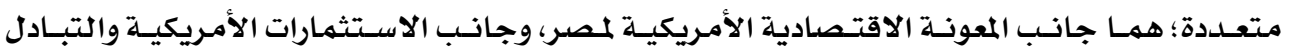

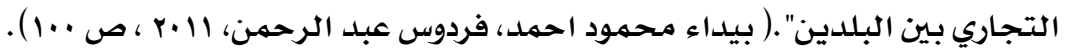
وهذا ما تجسده أغنية الطيب مـع زوجته الأميره نور، وهذا يتضح من التالى:

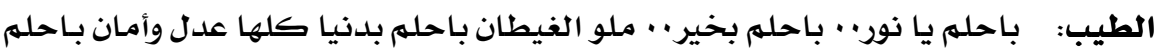

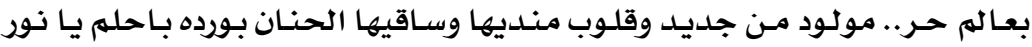

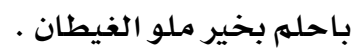

نور : باحلم ياطيب بالخمايل فى الرمال ونجوم كتيره منوره فوق التتلال بـاحلهم بورده

$$
\text { فى كل خد وكل إيد ويسمة دايمـة في عيون كل كل العيل العيال. }
$$

الطيب : باحلهم بناس مفيث بينهم حـزين ولا محتاجين ولا مقهورين ولا مطرودين وكل

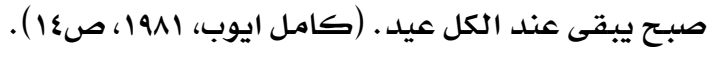

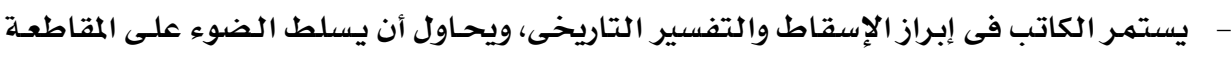

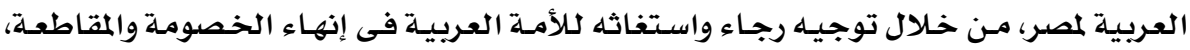

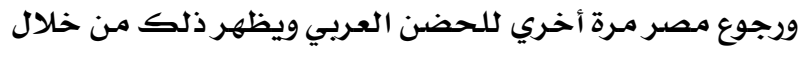

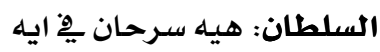

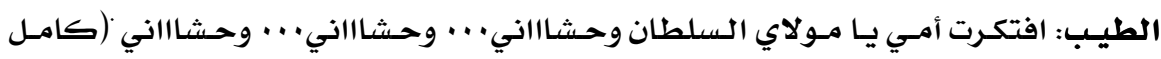

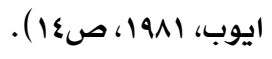


ثم يهـى الكاتـب فى انحيـازه المستمـر لأيديولوجيـة النظـام السياسي، ويؤكســ بـأن رؤيـة

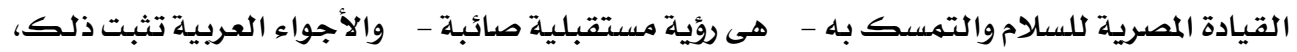

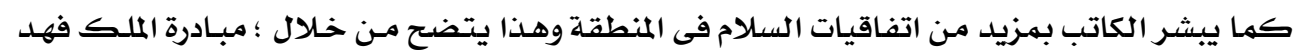

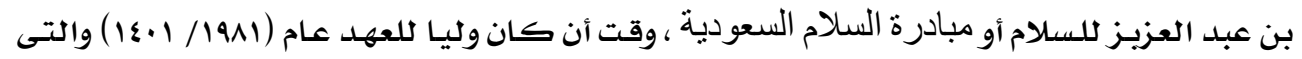

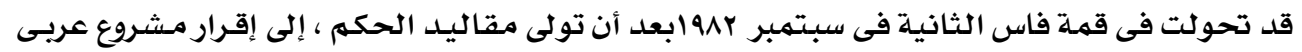

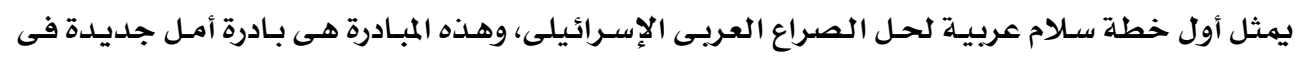

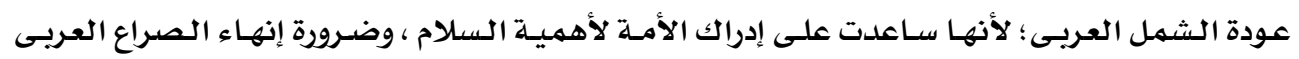

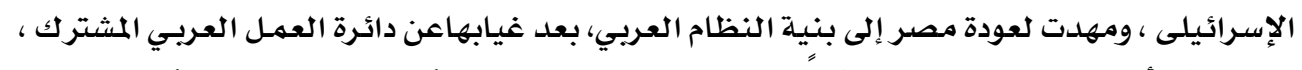

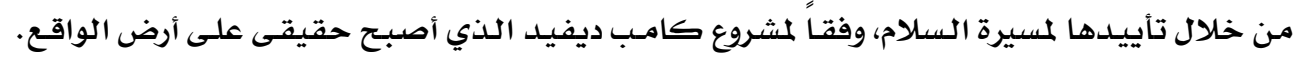

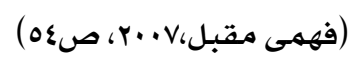

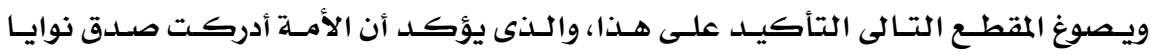

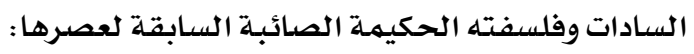

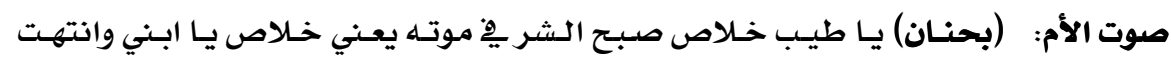

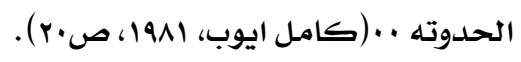

الحبكة الدرامية :

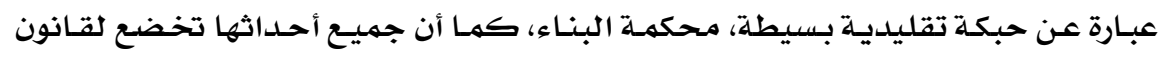

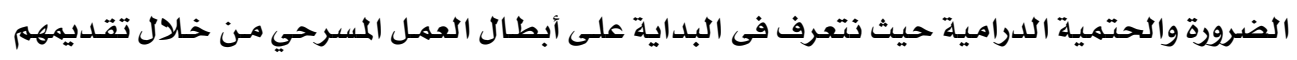

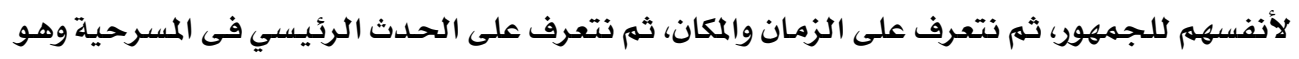

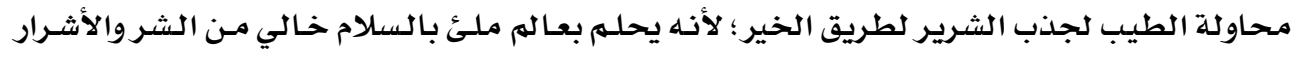
ويؤكد هذا بقوله.

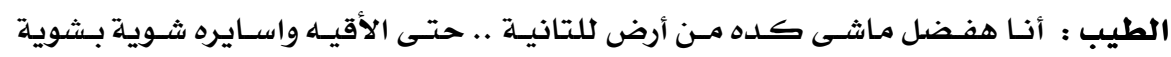

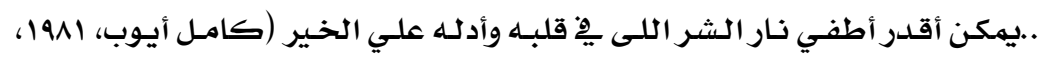

$$
\text { صنr). }
$$

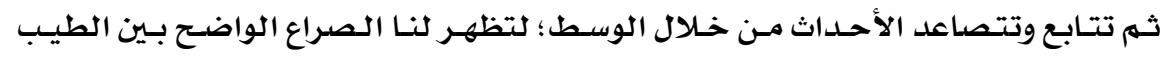

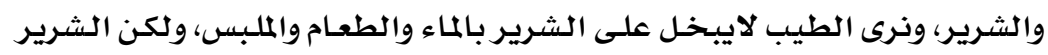

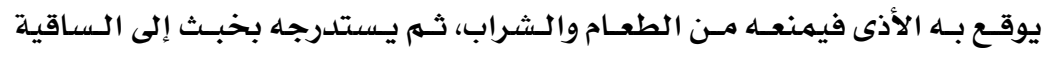

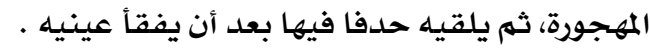

الطيب : (على حرف الساقية وهو يصرخ) ناوى تعمل فيه إيه؟

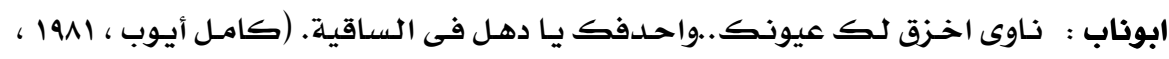

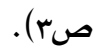


ولكن عناية الله وعدله وتوفيقه ترشده على الشجرة المسحورة داخل السـاقية ؛ لتكون سببـا

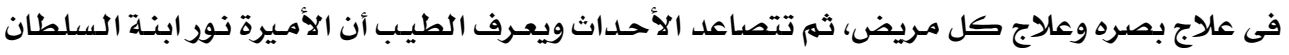

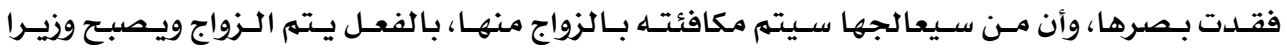

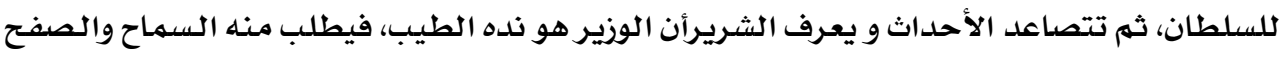

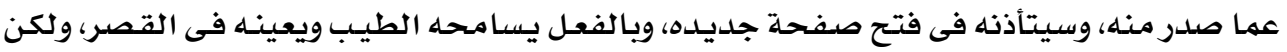

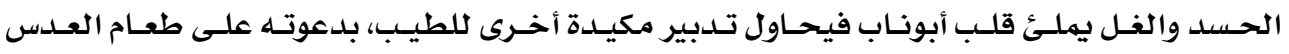

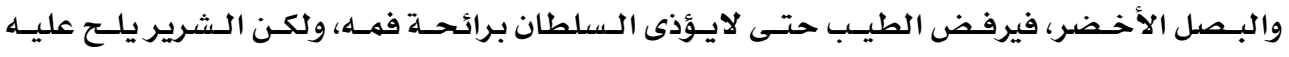

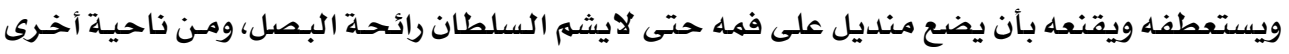

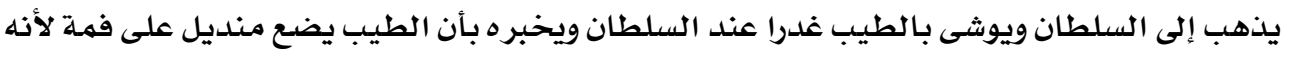

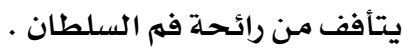

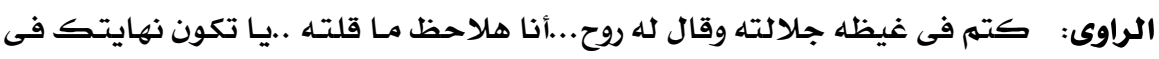

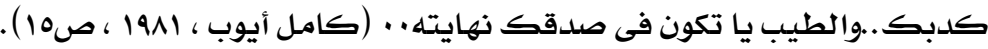

وفى النهاية نجد عناية الله تكون سببا فى نجاة الطيب وسعادته وأيضا سببـا ِِّ قتل الشرير،

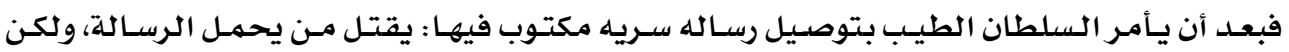

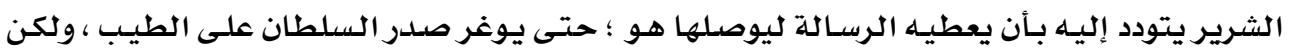

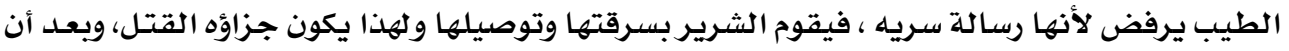

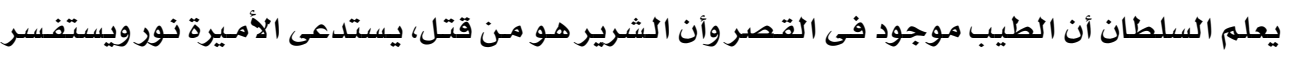

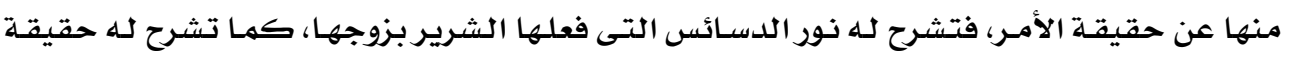

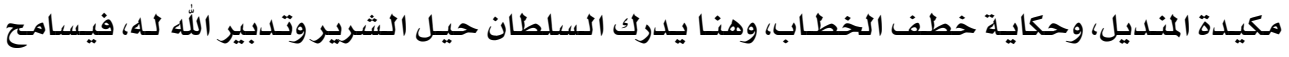

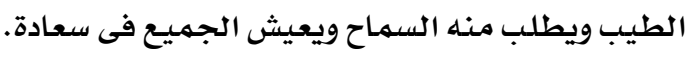

الراوى : السلطان جاله خبر إن الطيب موجود فى القصر ومـارحش برسـالته .. هـام غضبـه

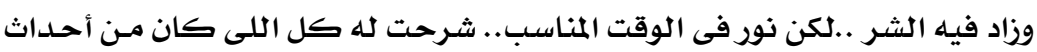

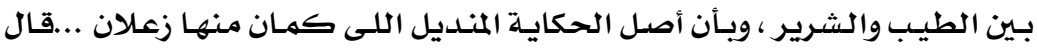

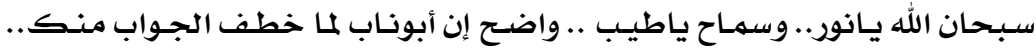

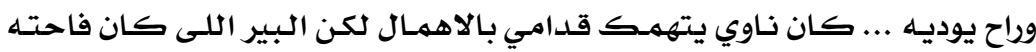

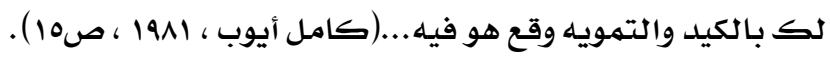

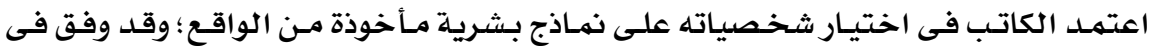

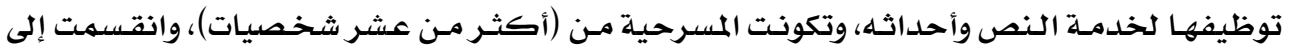

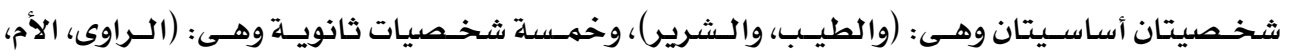

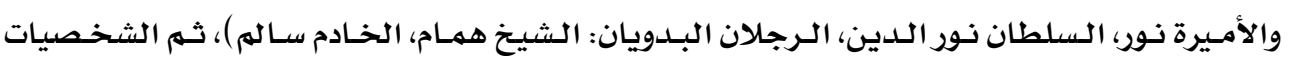


الهامشية مثل: (المنادى، رئيس العسكر، الحـراس، أهل المدينـة، والأطفـال والصبيـان الذين قاموا بـأداء الاستعراضات والغناء).

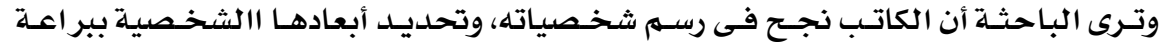

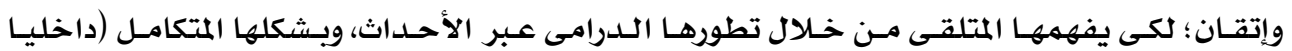

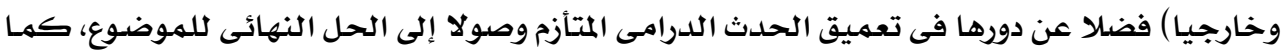

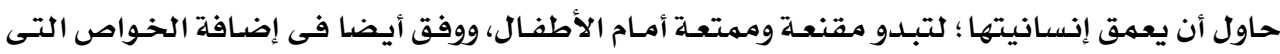

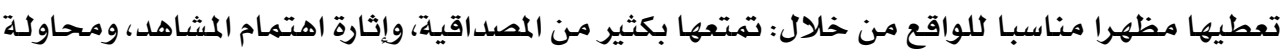

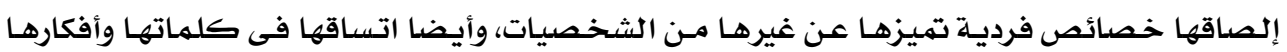

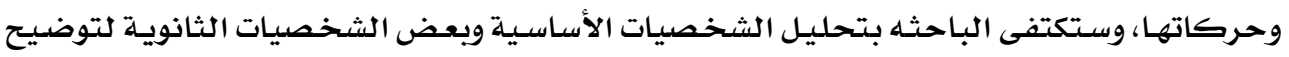

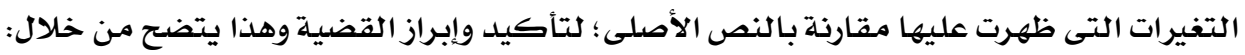

| الشخصيات الأساسية

-

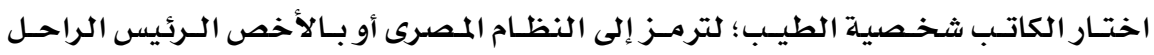

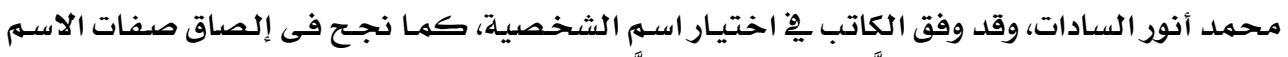

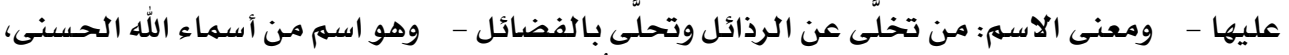

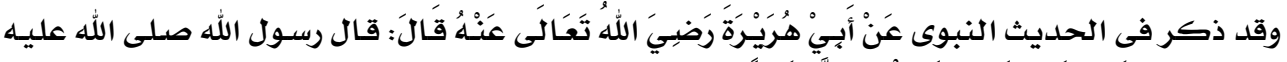

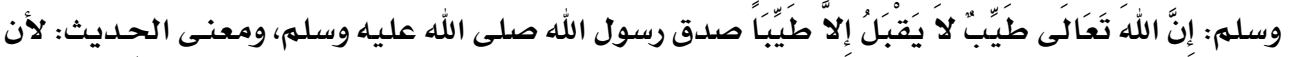

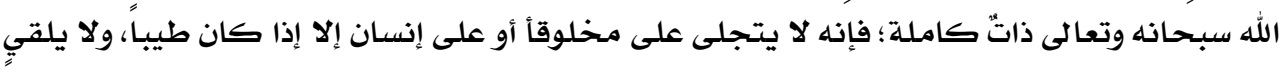

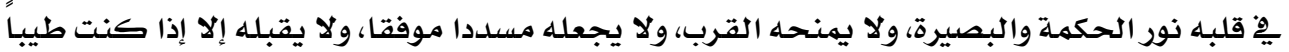

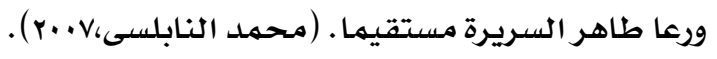

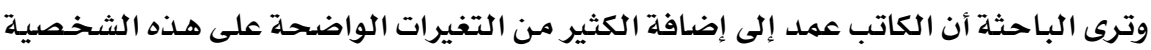

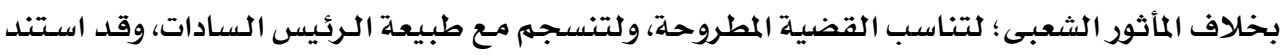

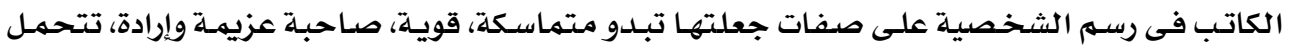

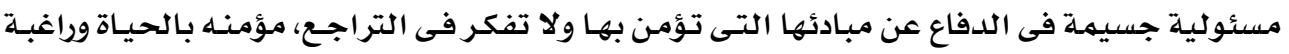

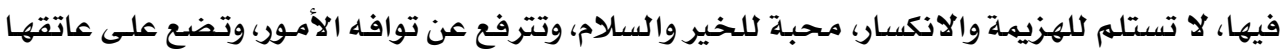

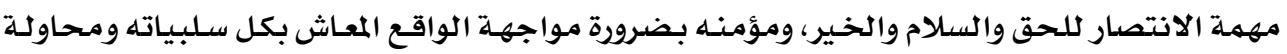

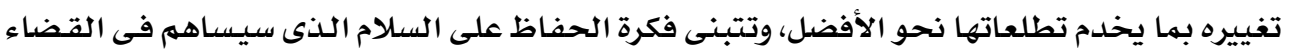

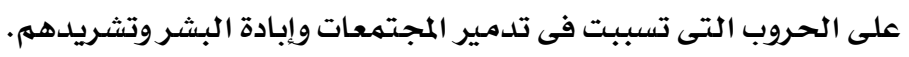
ولهذا نرى الطيب فى المسرحية هو الذى يصر على البحث عن الشرير؛ ليعلمه طريق الخير

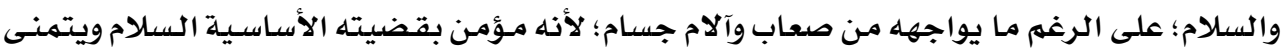

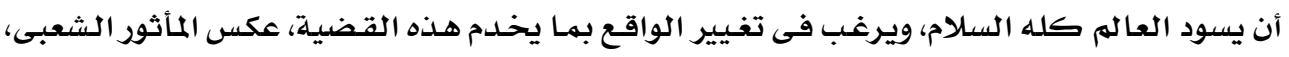
والذى يؤكد أن أبونية وأبو نيتين تقابلا صدفه، وهذا فيه إسقاط سياسي للسئ لسادات على أنه رجل سلام 


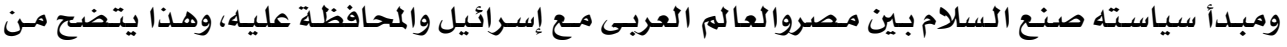

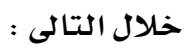

الراوى : وتقول الحدوته يوم ورا يوم ..أسبوع ورا أسبوع ..شهر ورا شهر والسنـة تبقى سـنين .. والطيب مـا خـلاث نـاس ولا حى ولا زقاف.. سـكة تجيبـه وسكة تواديـه ... وحكايتـه

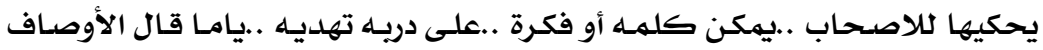
والأمـارات ..اللى حداه ...ياما نصحوه وحطوا قدامـه الخوف .. لكن شئ فى ضهميره كان بيقول لا .. لا لازم فى يوم ألقاه واثبت للدنيا أن الخير هو الأصل فى الإنسـان

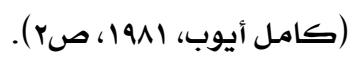

كـذلك نـرى إصــرار الطيـب علـى الخـروج مـن الـسـاقية المهجهـورة علـى الـرغم مـن المعانـاة الشديدة التى كان فيها عكس المأثور الشعبى، والذى يؤكد أن أحد المارة أخرج أبونية مـن البئـر، وهنـا يحاول الكاتب التدليل على قوة وعزيهـة السـادات وعـدم استسـلامـة للهزيهـة والنكسـة، وهـذا يتضـح مـن خلال التتالى :

(إضـاءه ثم مـوسيقى راقصة ...والأطفال يؤدون آهـات ذات طـابع دينـى حـول السـاقيـة .. يخـرج الطيب بصعوبـة من الساقية ...يخرج الأطفال مـن المسرح ..ويبقى فى حالـة إعيـاء..يتحسس الأثـياء

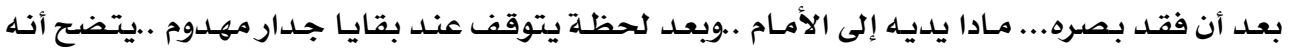
غارق فى أحزانه الداخلية قبل أن تدب فيه الحيوية فى مواجهة خيالاته ..تظهر الأم فى مكان مـا على المسرح ..فى حالة حداد واستغاثه وولوله ...الطيب يغير مكانه فى بشاشـة طفليـ) .. . . (كامل أيوب، (1.) 191)

أيضـا نرى أن الكاتب استبـل الكنز المدفون تحت الشجرة فى المأثور الشعبى وسـرقة أبو نيـة له، بتهـر وأوراق شجر فقط ، وأكد أن الطيب قرر أخذ أوراق الشجر فقط ؛ ليعالج عينيـه ويكون سـببـا

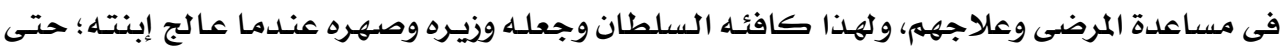
يؤكل أن الرئيس السـادات عزيز النفس لا يطمـع فى المعونـة الأمـريكيـة على حسـاب مبـادئه وقضاياه،

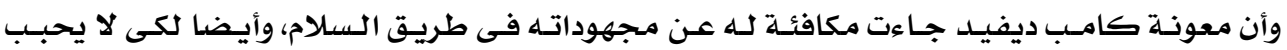
الأطفال فى السرقة وهذا يتضح من خلال :

الطيب : دلوقتى فهمت منـين التهـر لقيته فى جوف السـاقية ومنـين ورق الشجر اللى

لقيته هناك أكوام ... يا ترى دا اللى سمعتـه حقيقـة ولا أحسلام آدى السـاقية اللى

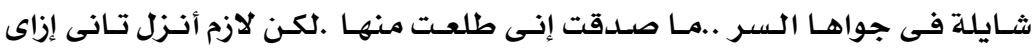
...وأنـزل ليـه ؟ أيـوة أفـرك ورقـة ولا اتـنـين مـن ورق الشجـرة ..وأكحـل عينـى منهـا حسب وصفة الشيخ اللهى رواهـا ...يهكن ألاقى نفسى مفتح عينى .بكـرة الـببح .طيب والله دنا كنـت ..امـلا توبى أوراق ...واطوف فى البلـدان لاجـل اعـالج كل

جريح واداوى كل عيان. • (كامل أيوب، 1911 ، ص111). 


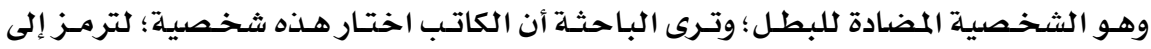

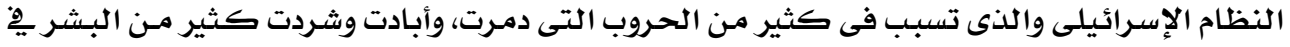

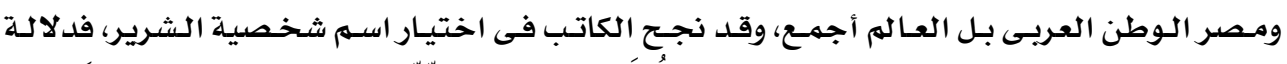

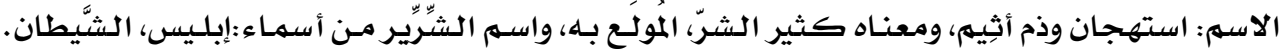

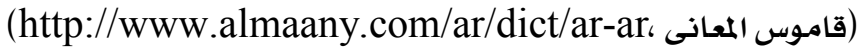
ويتضح بعض الصفات لهذه الشخصية فى المقطع التالى : الشرير : أنا فى الغث خبير غاوى اعمل مسامير أستاذ فى التدبير لى تلامذه كتير

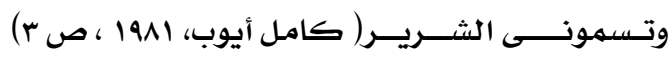

وتجد الباحثة أن الكاتب أضاف العديد من التغيرات الواضحة علي مستوى هذه الشخصية

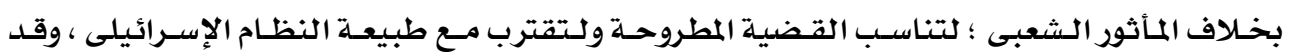

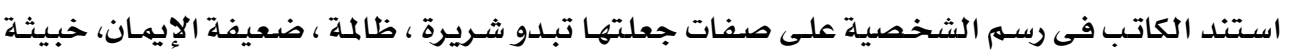

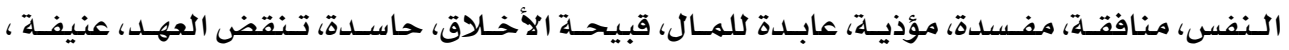

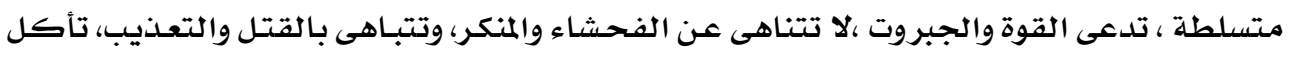

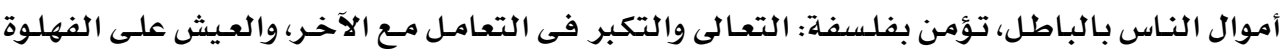
والبلطجة والسرقة ، وكذلك التربص والوعيد لكل من يقف أمام تحقيق مطامعها.

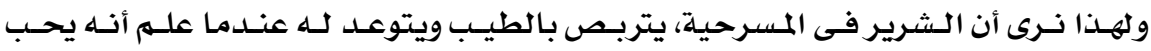

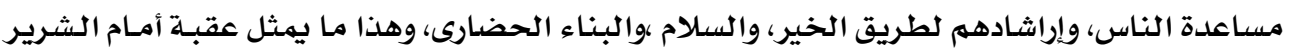

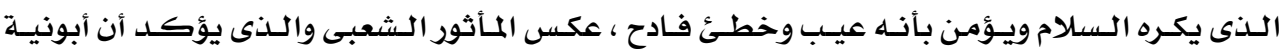

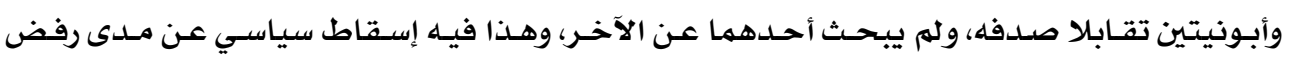

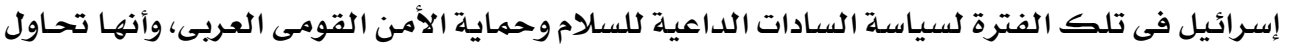

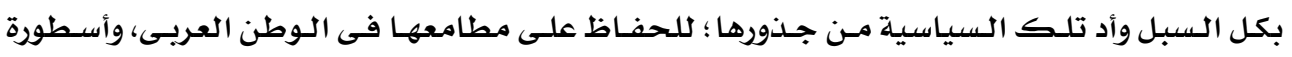

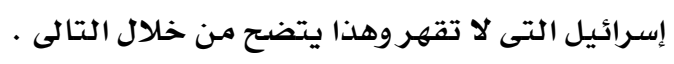

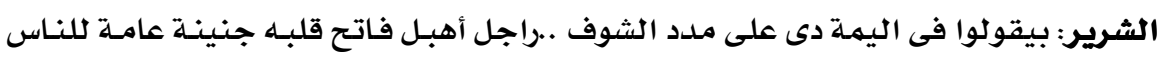

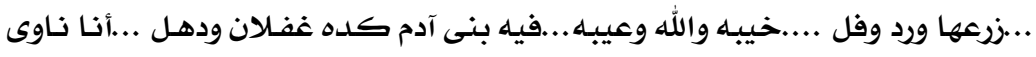

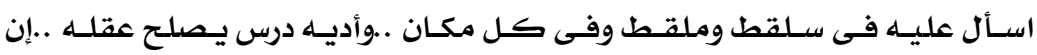

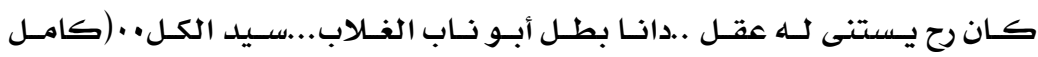

$$
\text { أيوب، (1911)، صنب). }
$$

كهما تنبـأ أيضا الكاتب بنهايـة إسـرائيل على يـد الآلـه العسكريـة الأمريكيـة أو الاستـخبارات

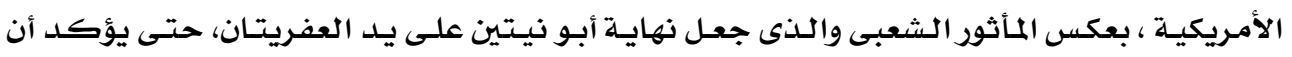




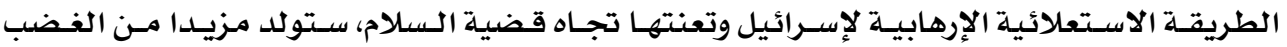

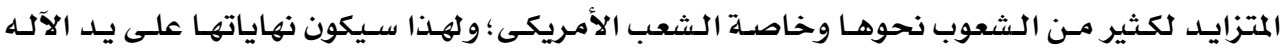
العسكرية أو الاستخبارات الأمريكية.

رئيس العسكر: (للجنود) شوفوا .....الراجل دا اللى جاب مكتوب مولانا السلطان العادل

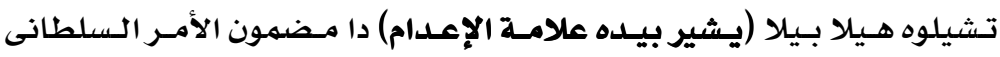

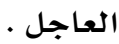

الجنود : حالا ...حالا .. أمـر جلالتهه هيتنفذ بالكامل (موسيقى وإضـاءة وإظلام توحى

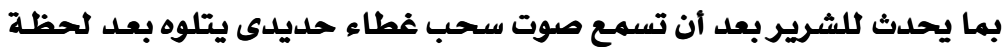
صوت إستغاثة الشرير)

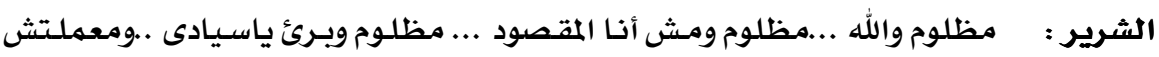

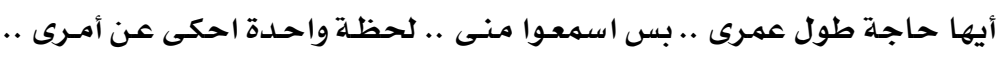

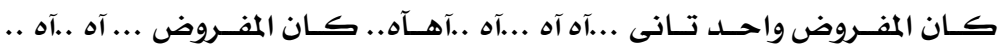

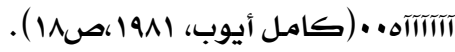

r r r الشخصيات الثانوية : - مخصية الأم :

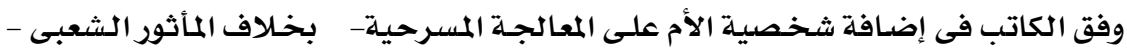

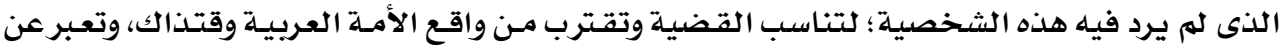

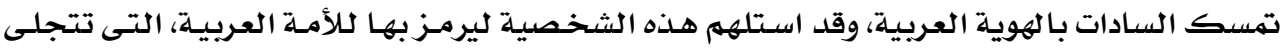

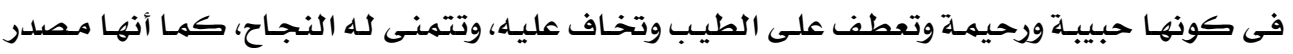

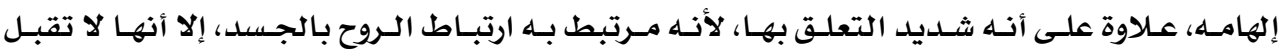

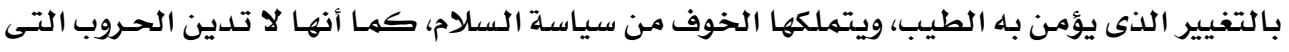

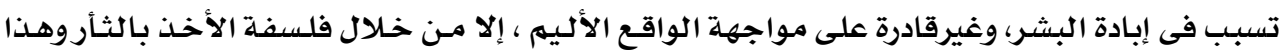

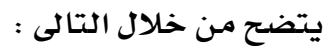
الأم: ناوي برضده يا ضناياتروح يمة الشرير برجلك. جنب أمك.. وسط ناسك . .واهلك فينائرح

$$
\text { الطيب: إنتي يا امـه جوه قلبي... فين أروح.. طيفك سابقني }
$$

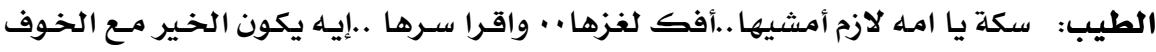

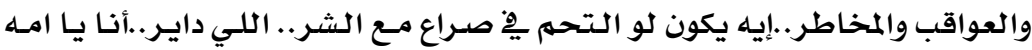

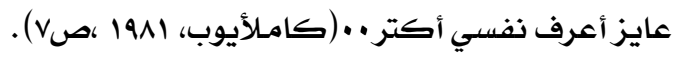




\section{وفى مقطع آخر :}

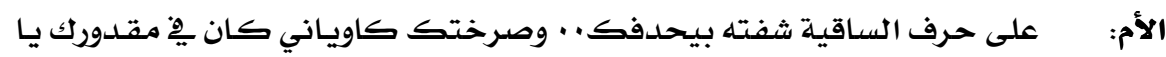

$$
\text { ولدي تحدفه انت وتنتجي }
$$

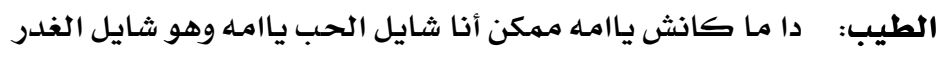

$$
\text { الأم: يعني يا ابني تروح قتيل }
$$

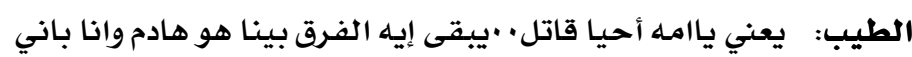

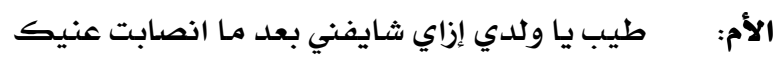

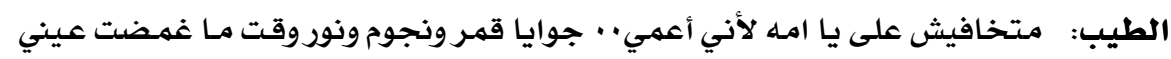

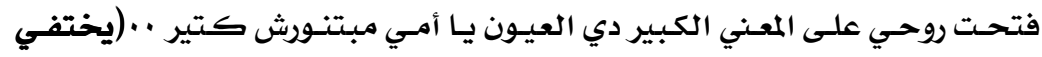

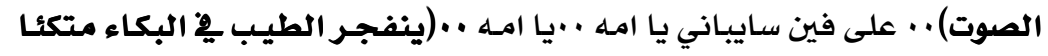

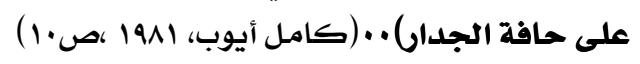

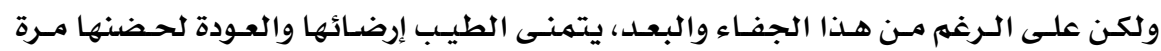

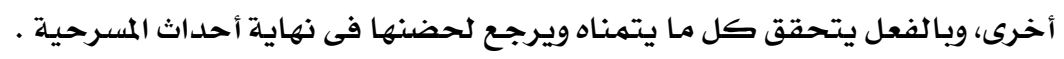

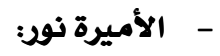

أجاد الكاتب فى رسم شخصية الأميرة نور، وقد حساول الكاتب إضـافة بعض التغييرات على التى

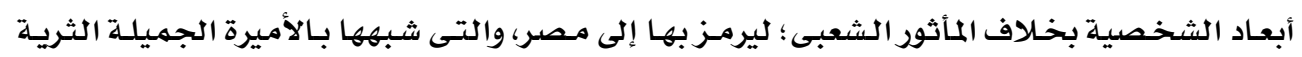

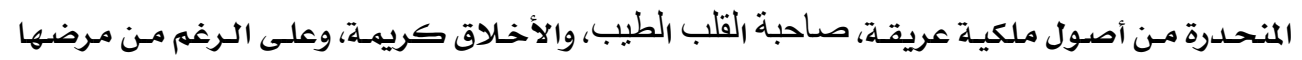

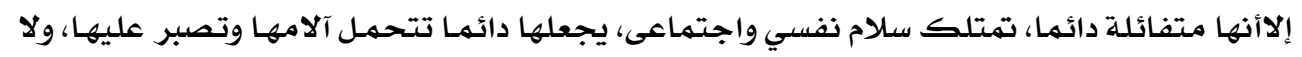

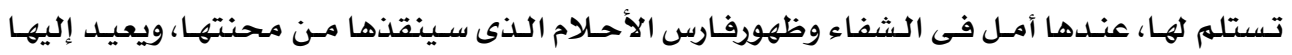

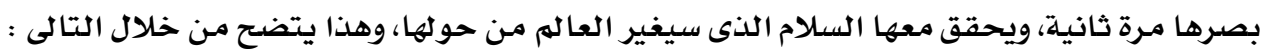

$$
\begin{aligned}
& \text { الأميرة نور: نسمسة رايحة ونسمة جايه أنا شمعة يا شمعايه ياللى }
\end{aligned}
$$

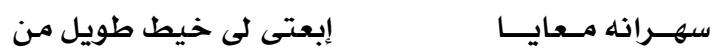

$$
\begin{aligned}
& \text { شعــاعــك الجميـل لاجل أطرزتوب هنايا }
\end{aligned}
$$

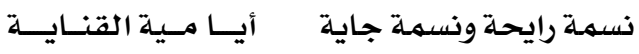

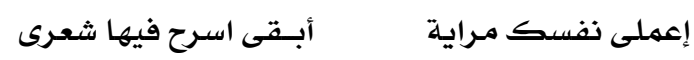

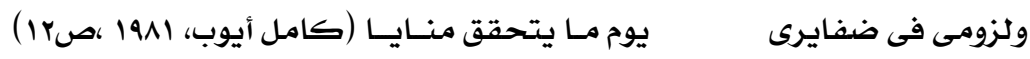

وبـالفعل يحقق الله آما لها، ويـأتى إليها الفـارس الطيـب المنقـذ، ويـدخل على قلبهـا الفرحـة،

ويعيد إليها بصرها ثم يتزوجها، كما يجتهد فى تحقيق أحلامها التى تتطسابق مـع أحلامهـ، وهـذا مـا يدل على إسقاط سياسي يؤكد بـه الكاتب أن القائد تزوج مـن مصر رمز السـلام وهو رجل السـلام ورجل

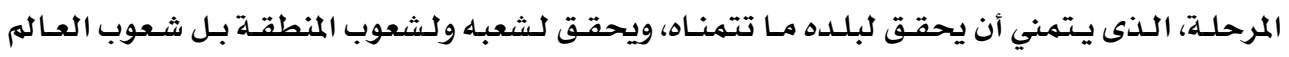


أجمـح، عصر جديد يعمـه الرخاء، والازدهـار، والتنميـة، والتغييير كلأفضل، وخـالى مـن الحـروب والدمار، وهذا يتضح فى التالى :

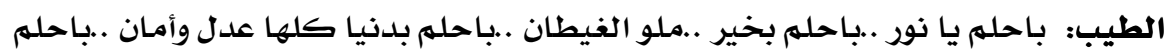

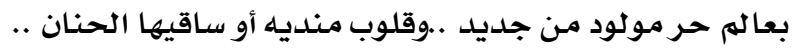

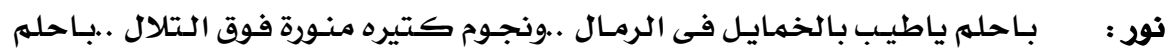

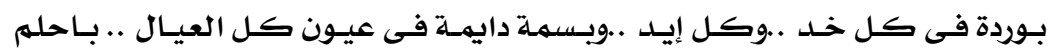

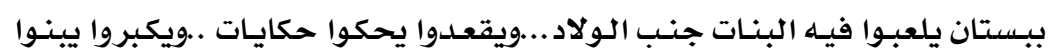

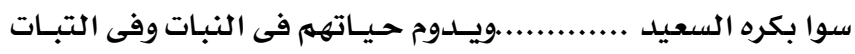

الطيب : باحلهم يانور بجنينة مالها باب ولا ليها سور

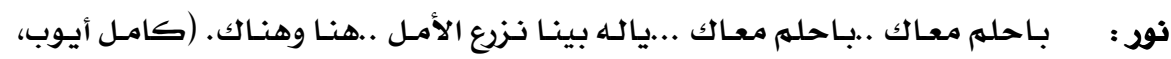

(1r) 1911

- مخصية السلطان :

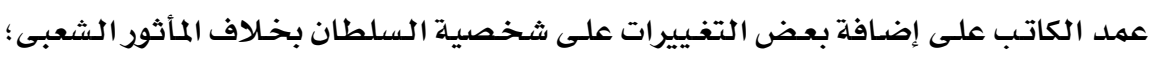

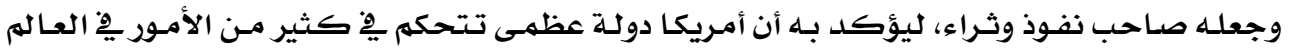

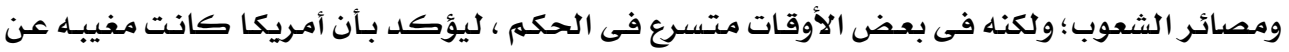

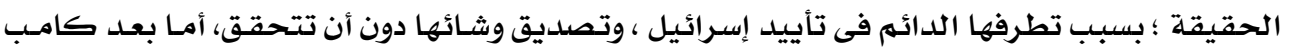

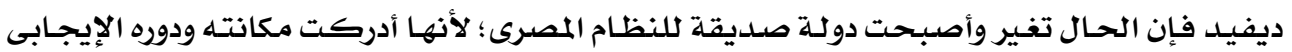

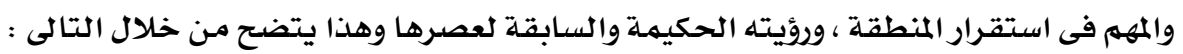

$$
\begin{aligned}
& \text { السلطان: أنا بقى سلطان العصر والأوان } \\
& \text { المفروض إنى احكم واعدل فى الميزان } \\
& \text { لكن عقلى مش دفتر .. بيغيب ساعات وبيحضر } \\
& \text { عشان كده ضروري سوا سوا تفكر } \\
& \text { إنت وهو وهي ..أصحاب أى قضيـة } \\
& \text { شوفو هيجرى إيه ... فى فصول المسرحية . }
\end{aligned}
$$

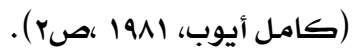

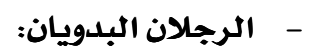

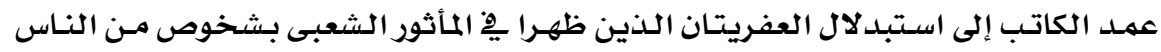

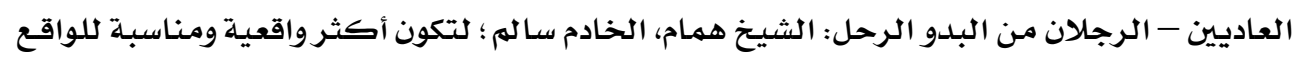

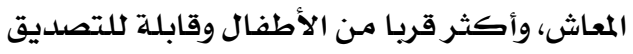




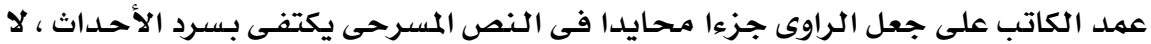

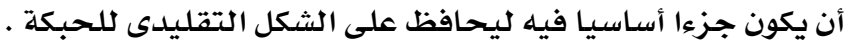

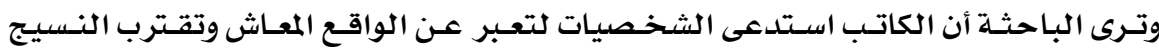

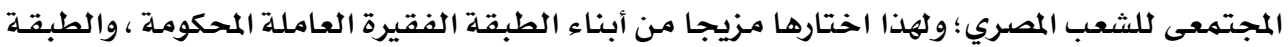

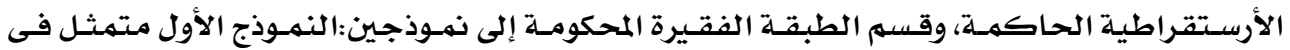

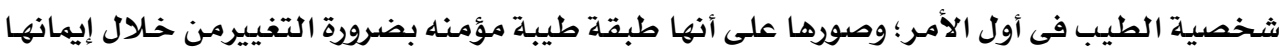

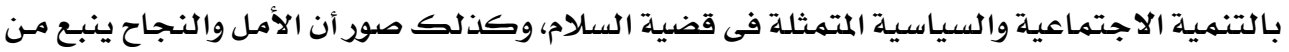

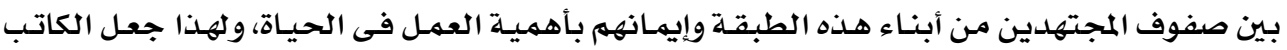

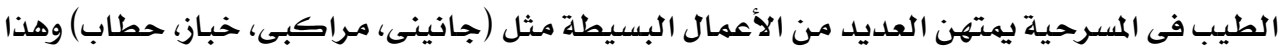
يتضح من خلال:

الرواى : الطيب سكة تجيبـة وسكة تودية .... يصبح في بلد ويبات فى بلد مـرة جـانينى ..مـرة

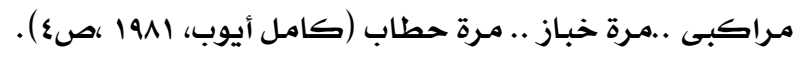

أما النموذج الثانى للطبقة الفقيرة: فهوالكسول والمتخاذل وقبيح النفس والذى يعتمد على فئى

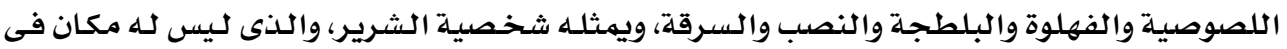

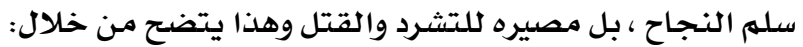

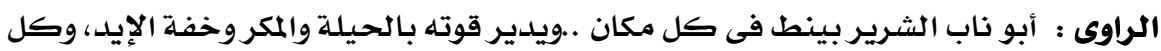

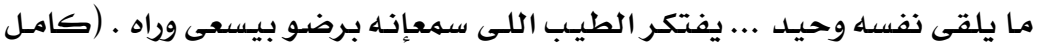

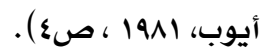

أما الطبقة الإرستقراطية الحاكمـة: فقد صورتها المسرحية على أنها طبقـة مثاليـة، وقادرة

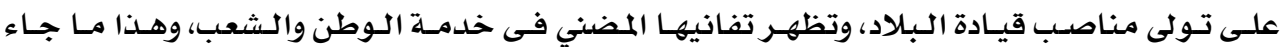

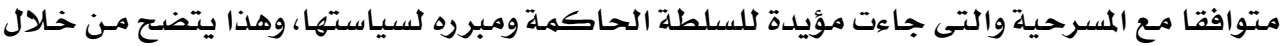

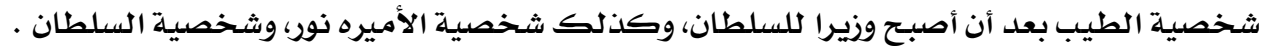

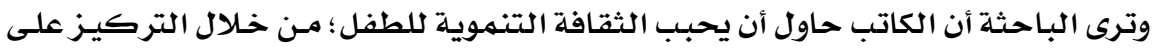

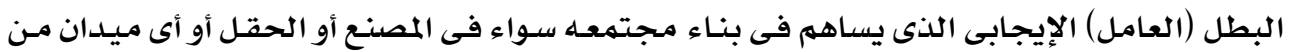

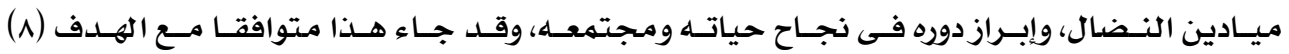

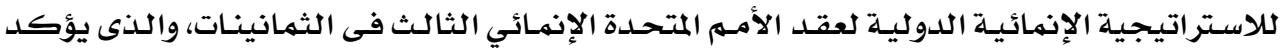

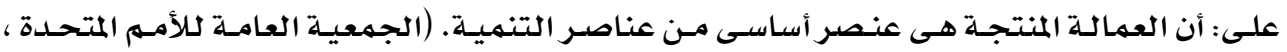

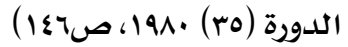


حرص الكاتب على استخدام الحوار الجيد السهل المعبر ، والذنى سـاهم فى تطوير الأحسداث

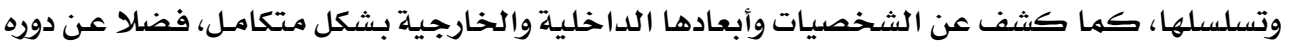

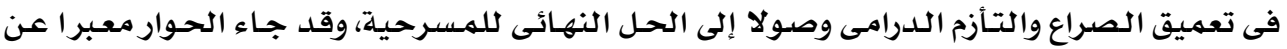

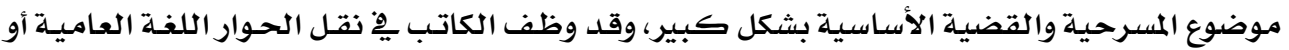

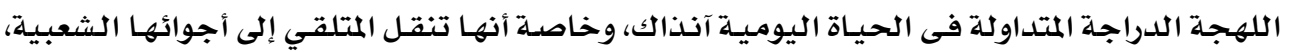

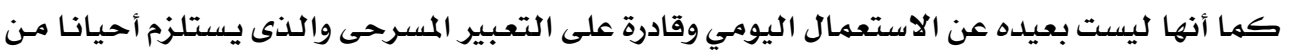

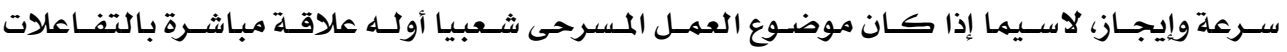
والقضايا التي تحتدم ِِِ المجتمـع.

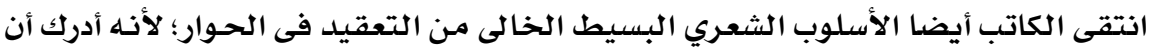

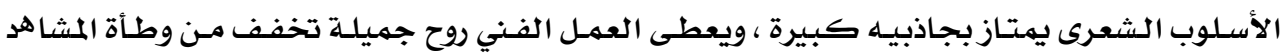

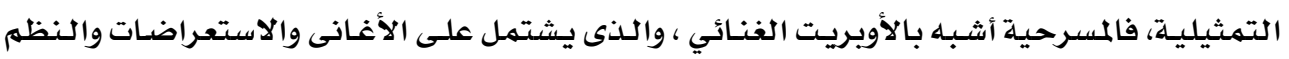

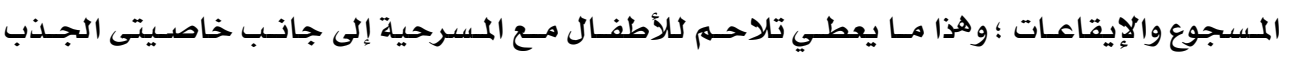
والامتاع.

وقد وفق الكاتب فى اختيار رصيد كبير من الأسـاليب ، والجمل القصيرة، والمفردات السهلة

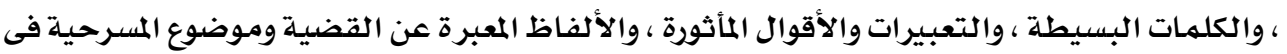

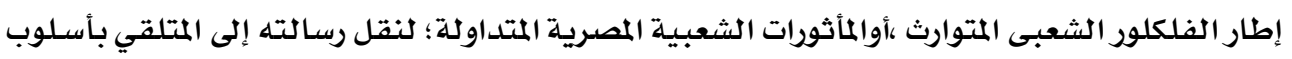

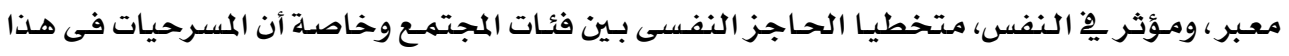

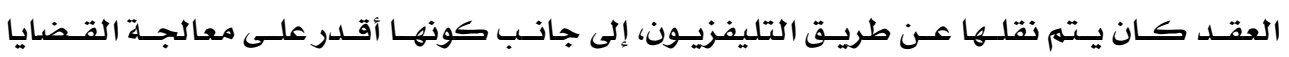

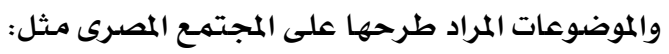

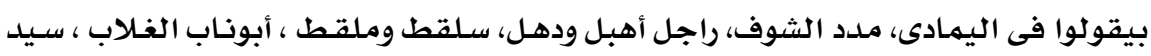

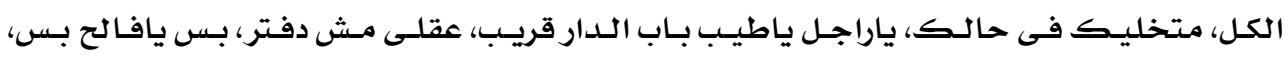
هاشوطك ورا الشمس، غاوى اعمل مسامير .....وغيرها.

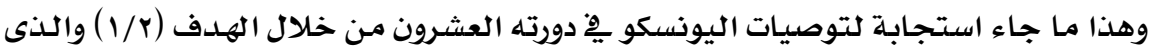

$$
\text { أكد على أهمية : }
$$

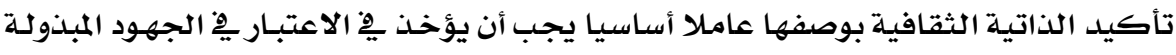

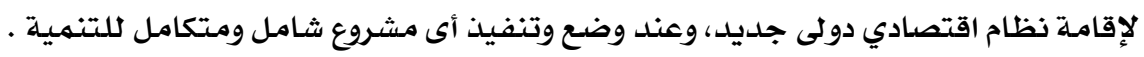

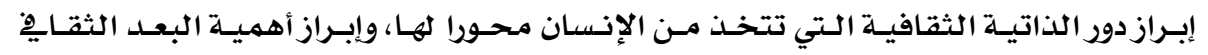

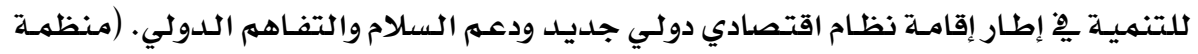

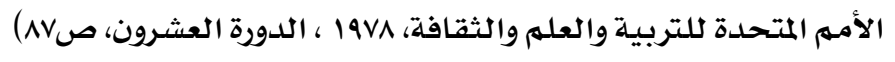




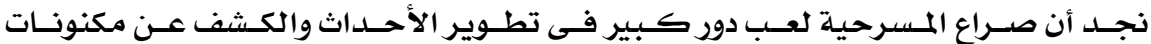

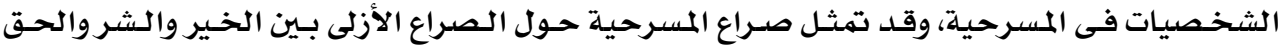

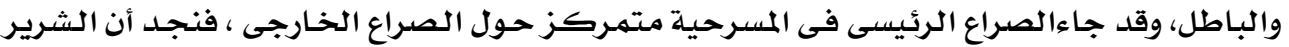

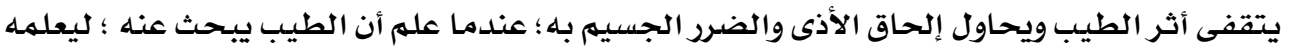

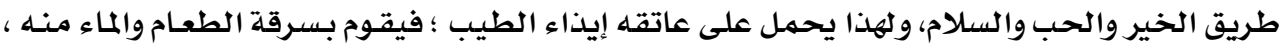

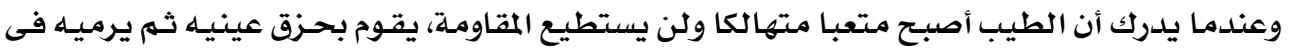

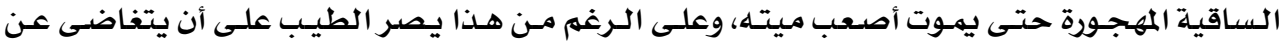

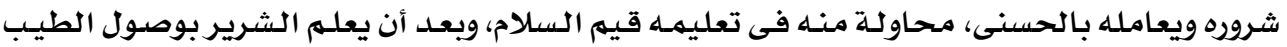

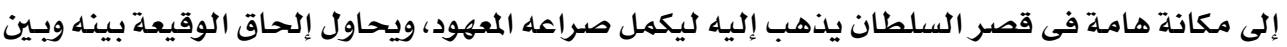

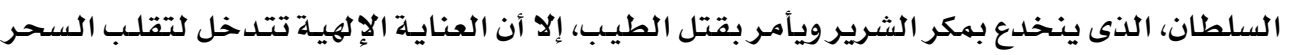

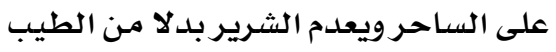

الشرير : ولا نافعة معالك يا طيب أى دسايس.. ولسسه مهم عند السلطان ..وهتسافر برسالة

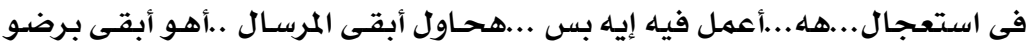

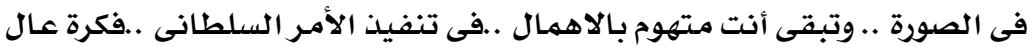

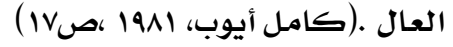
وبعد أن يسرق الخطاب من الطيب ويسافر ليعطيه لـرئيس العسكر ، تأتى نهايتـه المحتومـة

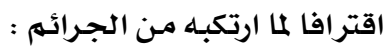

رئيس العسكر: (للجنـود ) شـوفوا .....اكراجـل دا اللى جـاب مكتـوب مولانـا السلطان العـادل

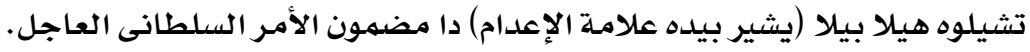

الجنود : حالا ...حالا .. أمر جلالته هيتتفذ بالكامل(موسيقى وإضـاءة وإظلام توحى بما

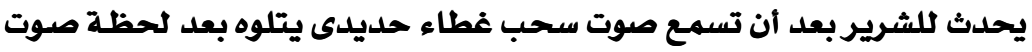

\section{إستغاثة الشرير)}

الشرير : مظلوم والله ...مظلوم ومش أنا المقصود ... مظلوم وبرئ ياسيادى ..ومعملتش أيها

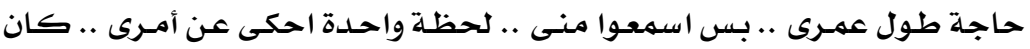

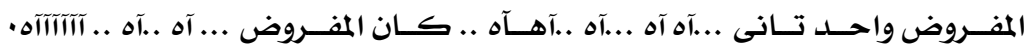

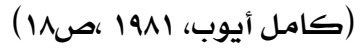

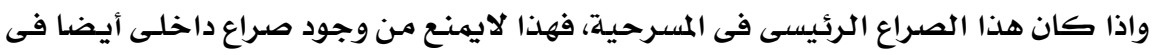

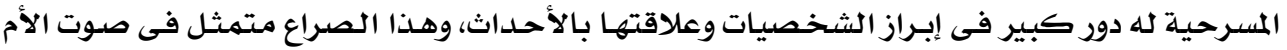

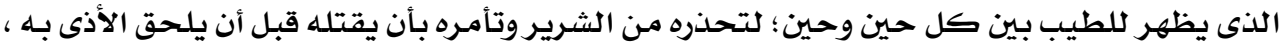

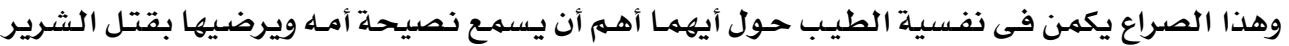


وإنهاء الـصراع، أم يسسمع صـوت إرادتـه الداخليـة، وضـميره الحـر بـالاسـتمـرار فى تعلـيهم الشريـر الحسب والخير والسـلام .

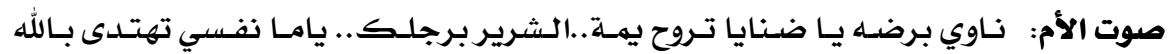
.وتبقى جنب امك... وسط ناسك وأهلك . .

$$
\text { الأميب: إنتي يا امـه .. جوه قلبي... فين أروح طيفك سابقني }
$$

الطيب: سـكة يـا امسه لازم أمسشيها .أفك لغزهـا . . وأقـرا سـرها ..إيـه يكـون الخـير مـع

الخوف والعواقب والمخاطر ..إيه يكون.. لو التحمى يِّراع مـع الشر اللي دايـر..

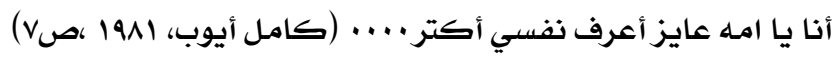

ويستـمـر هـذا الـصراع طـوال المسـرحيـة إلى أن تنتهـى بهـوت الشـريـر، واقتتــاع الأم بـأن الطيـب

كان على حق فى اختياره ، وأن طريق السلام هو الطريق الصحيح

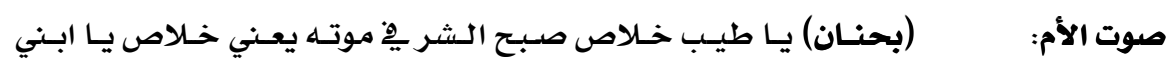

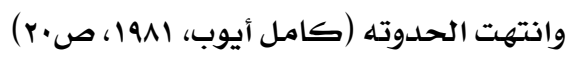

النهاية :

عند مقارنـة المعالجـة التى قدمها الكاتب بـانـص الأصلـى ، نجـد أن المسـرحيـة تخـتم بنهايـة

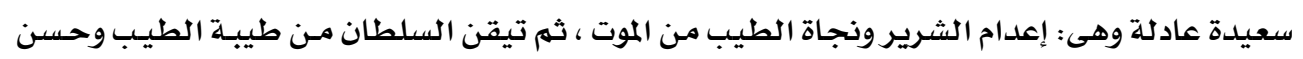
نوايـاه ، وسوء نية الشرير، وهذا مـا جـاء مـتوافقا مـع نهايات بعض روايـات النص الأصسلى، إلا أن الكاتب

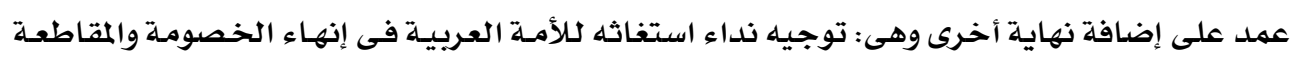

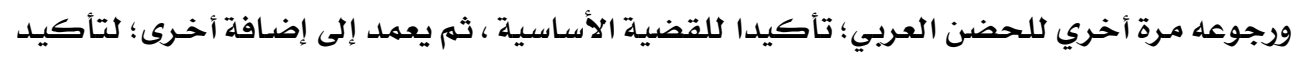

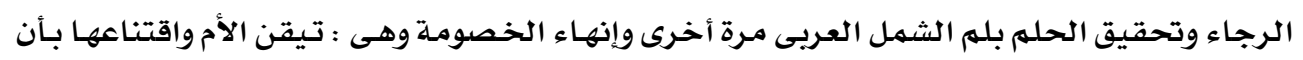

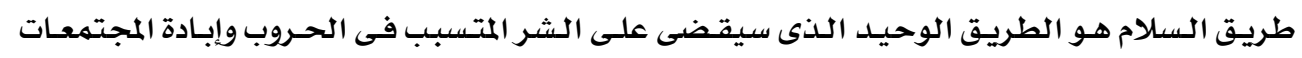
والشعوب وهذا يتضح من خلال: السلطان: هيه سرحان يِّ إيـه

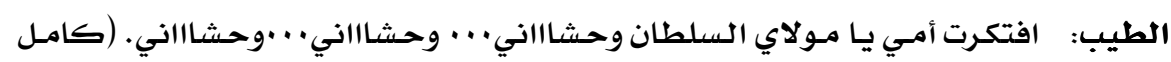

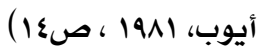

ثم تأكيد الرجـاء والحلدم مـرة ثانية من خلال:

صوت الأم: (بحنـان) يـا طيـب.. خـلاص صسبح الشر ِِ موته يعـي خـلاص يـا ابـي...وانتهـت

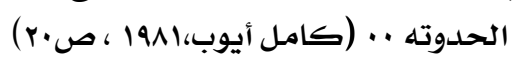

ولكن اقتضت الضرورة مـن الكاتب كامـل أيـوب إضـافة أغنيـة استعـراضية تربويـة لكلأطفـال

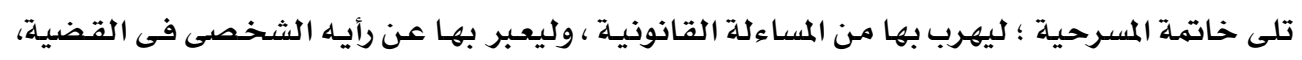

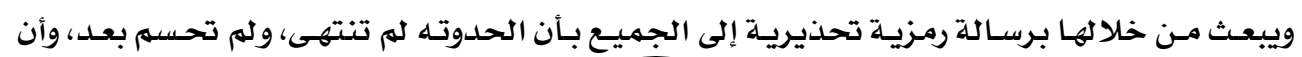




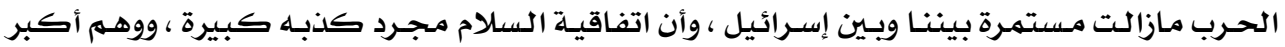

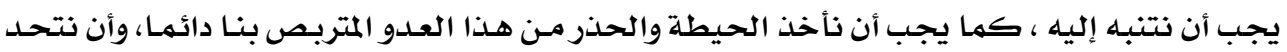

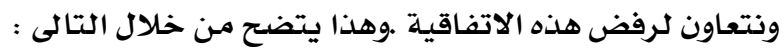

\begin{tabular}{|c|c|}
\hline لا مـا انتهتث الحدوته & لا مـا انتهتش الحدوته \\
\hline بين البـاطل والحق & والحـرب مستمـرة \\
\hline لأ لأ עأ עأ & لأ لأ لأ لأ لأ لأ \\
\hline فيـه زيـه لسـه كتير & ان كان مات الشرير \\
\hline ويلبدوا فى الشق & بيطمنوا فى الخير \\
\hline لأَ لأ لأ لأ & لأ لأ لأ لأ كأ لأ \\
\hline لا مـا انتهتش الحدوته & لا ما انتهتش الحدوتـه \\
\hline يالا نفتح عنينا & يالا نشبك ايدينا \\
\hline نقول له سوا لا & وان جا يضحك علينا \\
\hline 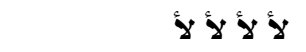 & لأ لأ لأ لأ لأ لأ \\
\hline
\end{tabular}

(كامل أيوب، ال 191، صنr ).

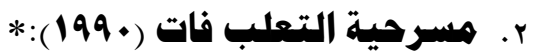
أولا تتائج الدراسة المتعلقة بالشكل :

إذا نظرنا لمسرحية "التعلب فات" نجد أنها عبارة عن أوبريت غنائى، يتناول موضـوعا فكاهيا

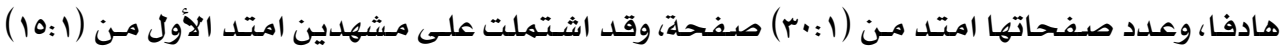

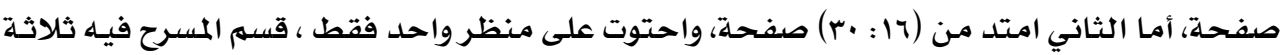

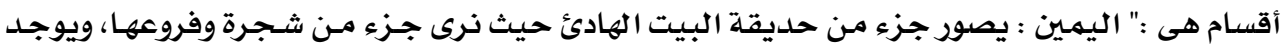

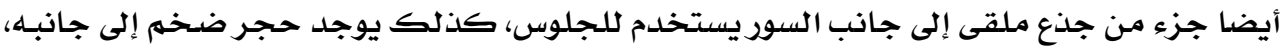

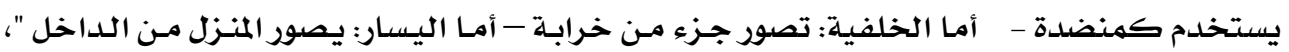

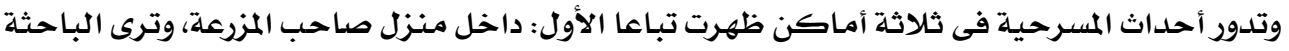

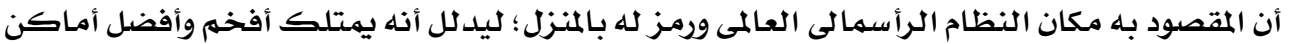

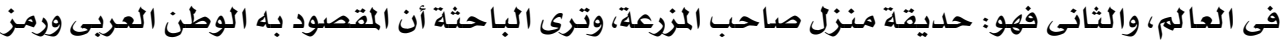

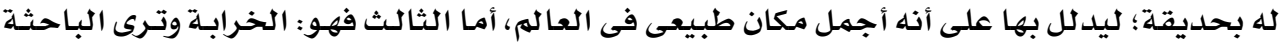

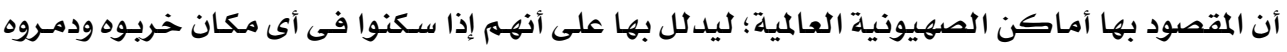

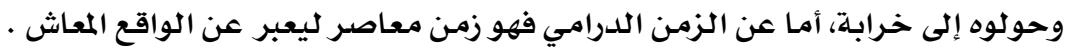

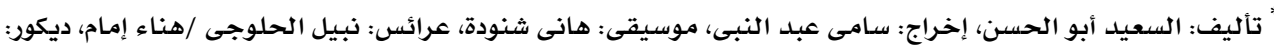

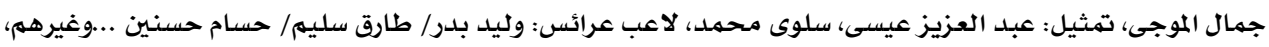

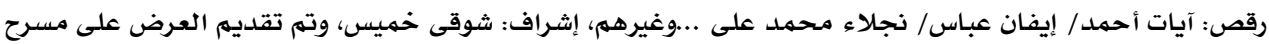




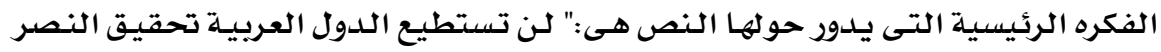

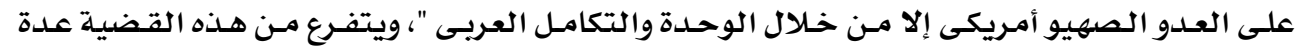

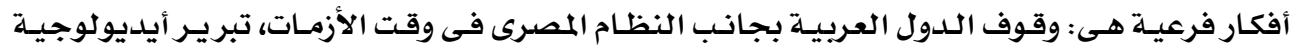

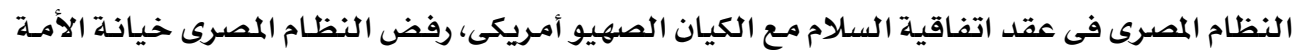

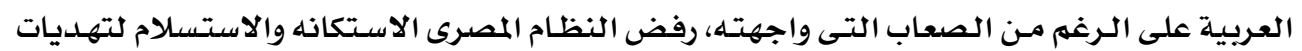

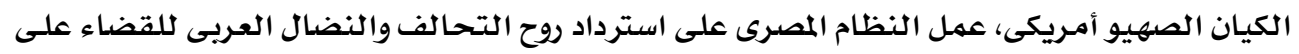

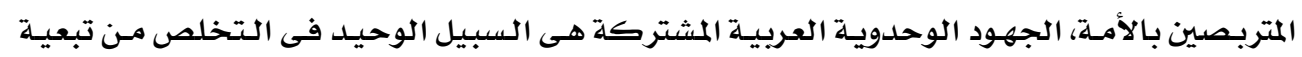

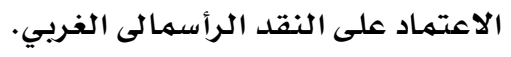

مصدر الفكرة :

استمدل المسـرحية رؤيتها الفكريـة مـن الموروث العـالمى - ت تراث شعبى ألمانى - عن حكايـة:

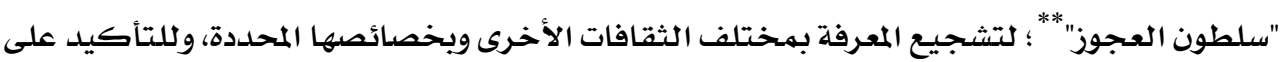
الطابع العالمى والقيم المشتركة بين الثقافات، وهذا ما جاء استجابة لتوصيات الوثائق التالية:

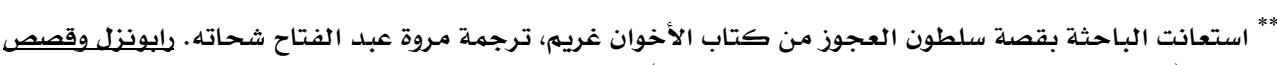

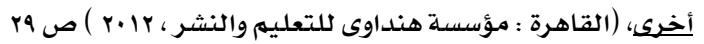

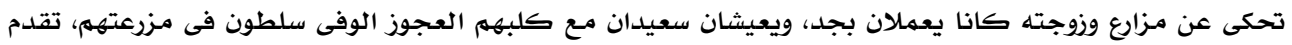

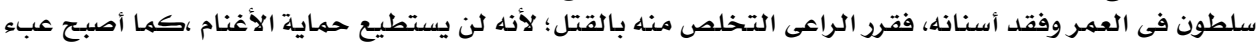

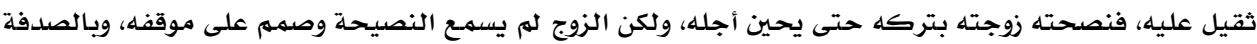

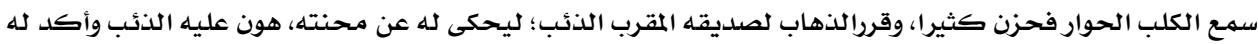

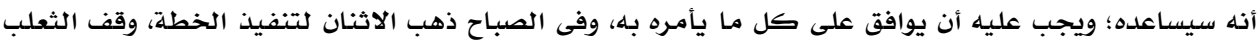

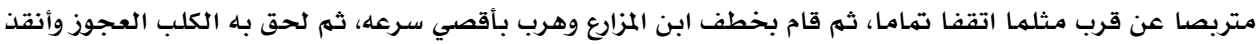

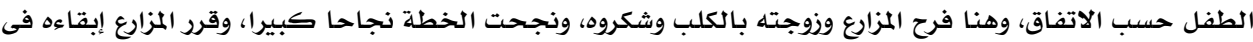

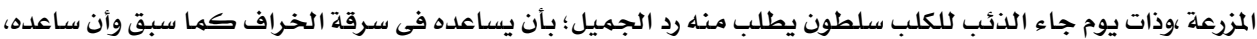

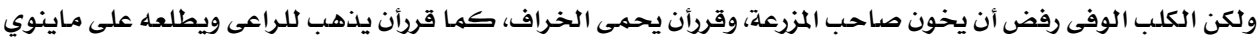

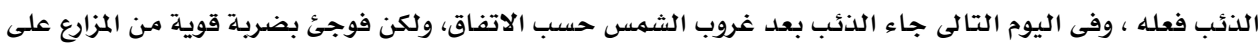

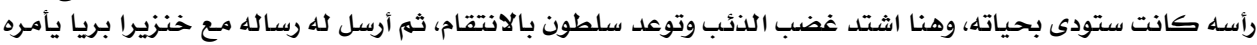

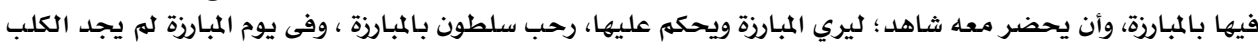

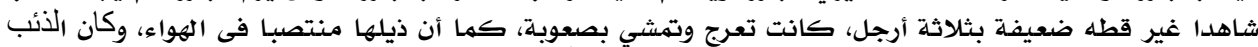

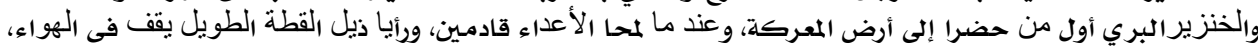

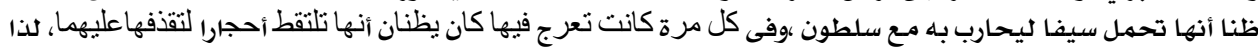

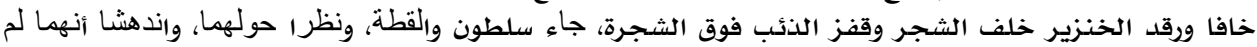

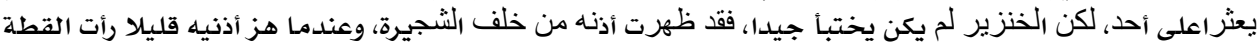

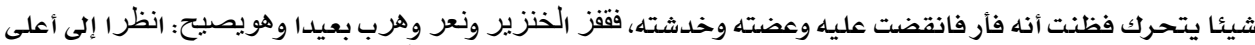

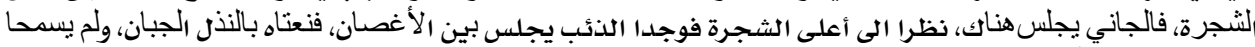

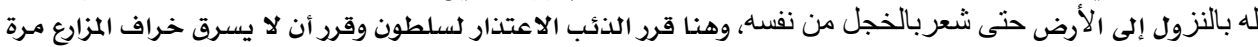
ثانية ويكون صديقا وفيا لسلطون. 
- قرارات اليونسكو ِِِ دورته الثالثة والعشرون لسنـة (1910) وفى إطار البرنامج r,؛ علدوم التربيـة

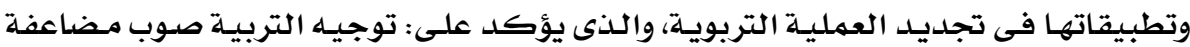

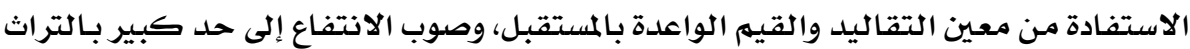

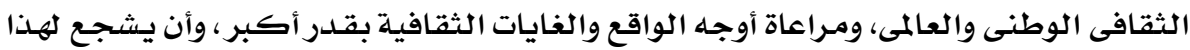

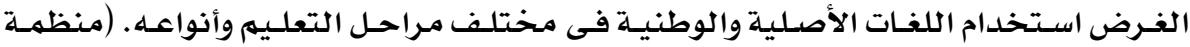

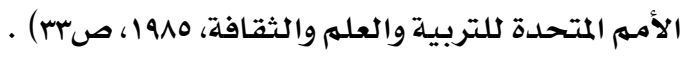

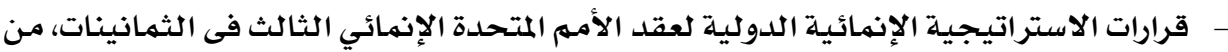

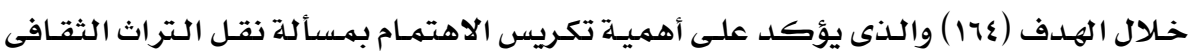

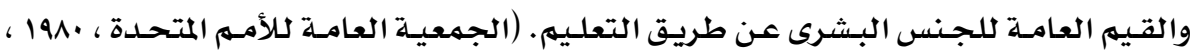

$$
\text { المعالجة الدرامية للنص المسروة (م)، صسا ) ). }
$$

تدور أحداث المسرحية فى مزرعة صغيرة تعيش فيها مجموعة الحيوانـات الطيبـة فى سـلام

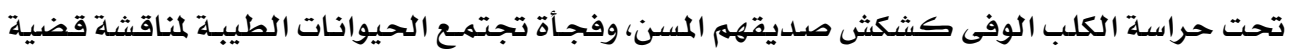

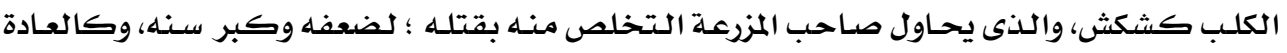

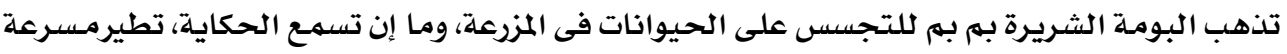

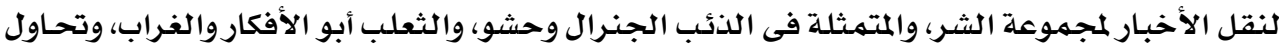

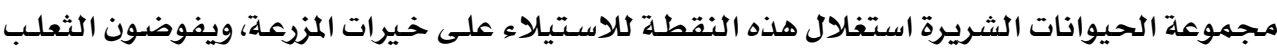

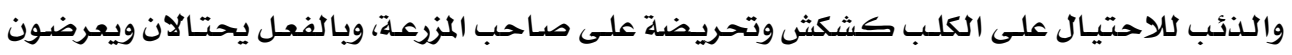

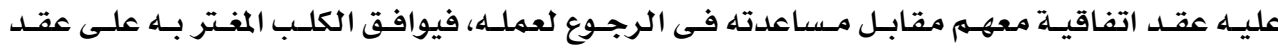

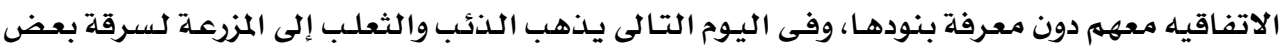

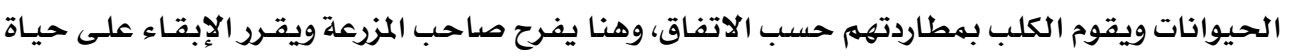

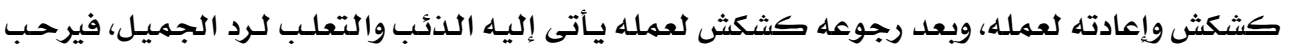

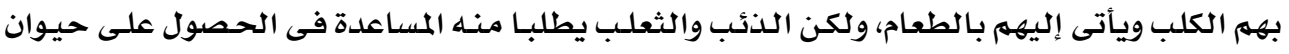

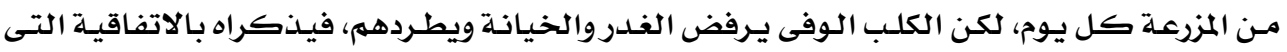

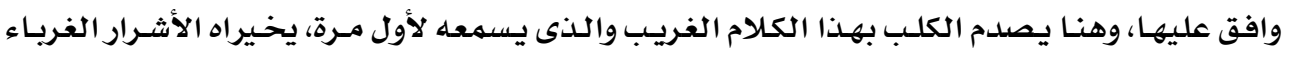

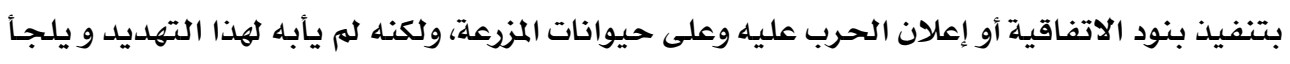

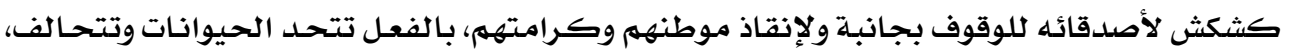

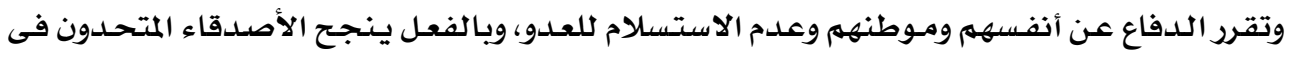

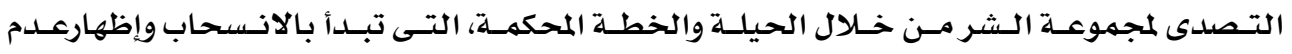

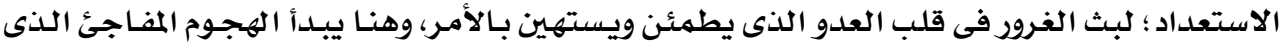

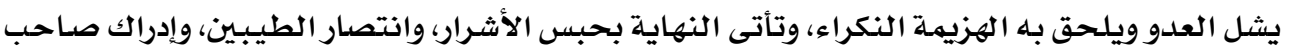

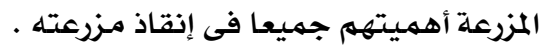


ترى الباحثة أن النص المسرحى عالج قضية أسـاسيةهىى: "إنهاء الصـراع العربـى مـع الكيـان

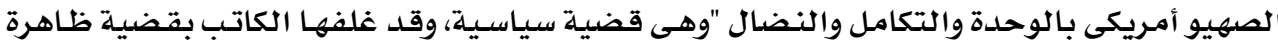

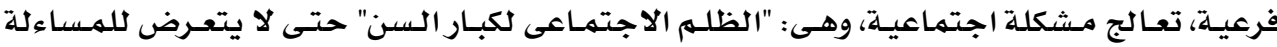

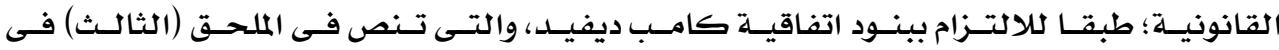

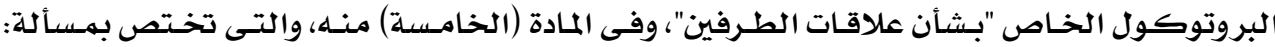

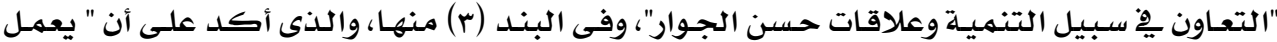

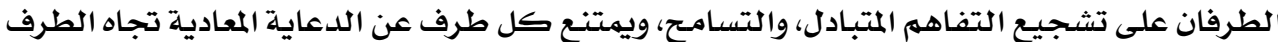

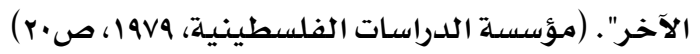

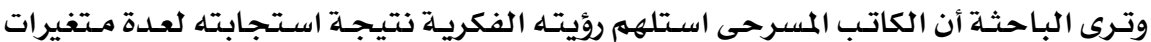

وتوجهات كانت أكثر إلحاحا على هذه الفترة وهى انس كالتالى :

أولا : التوجهات / القضايا المحلية التالية :

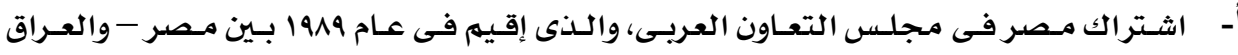

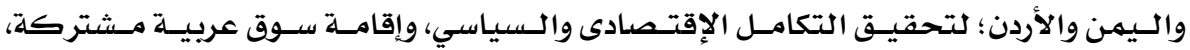

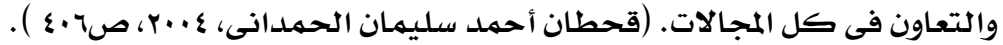

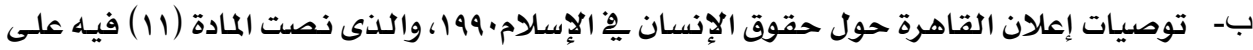

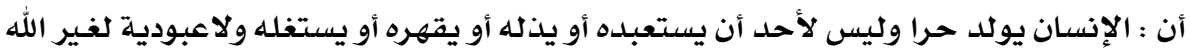

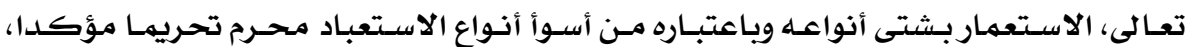

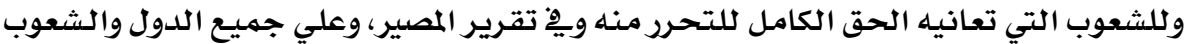

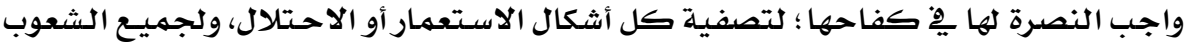

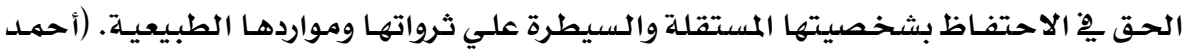

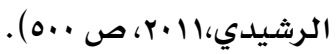

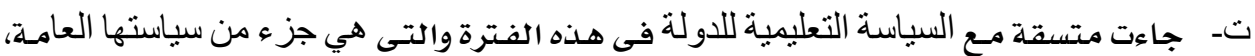

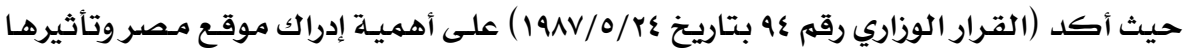

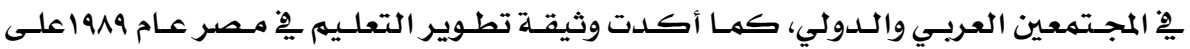

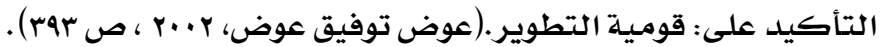

ثانيا : التوجهات/ القضايا الدولية التالية:

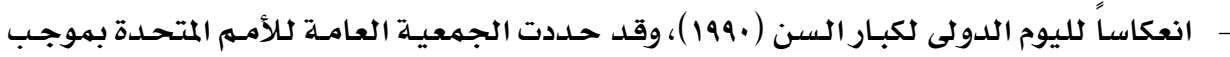

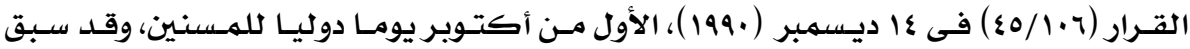

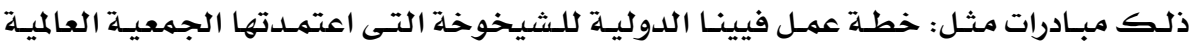




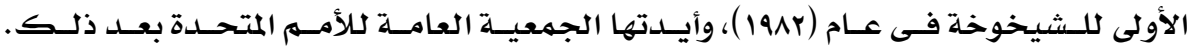

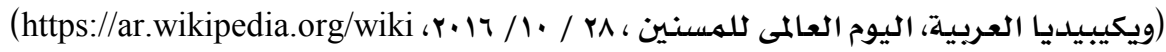

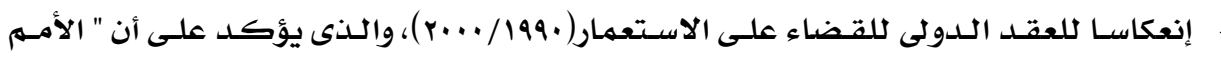

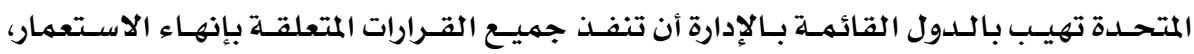

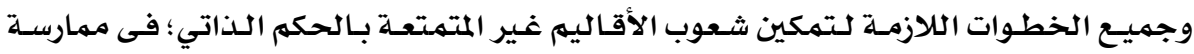

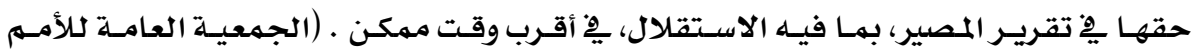

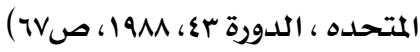

ثالثا : التوجهات/ القضايا القومية التالية:

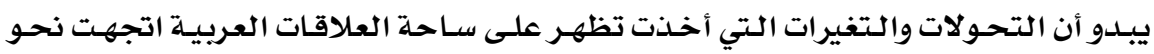

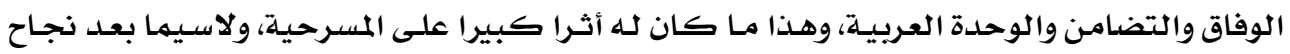

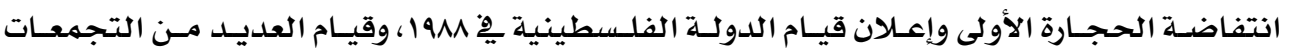

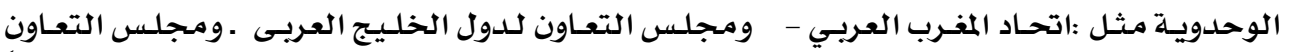

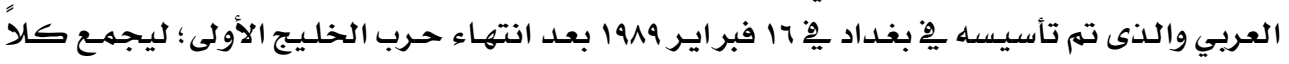

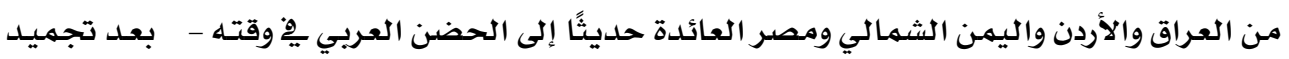

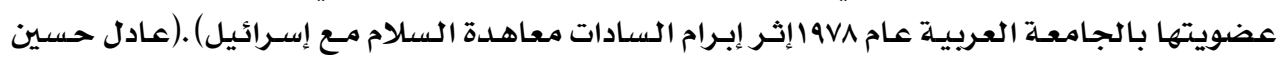
(₹)ص 1991،

ويعتبر هــا الحلـف كيانـا اقتصاديا، يـدفع بـاتجـاه دعـم الجهـود الوحدويـة الاقتـصادية

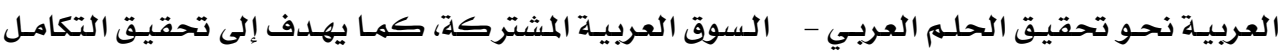

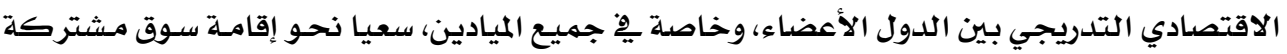

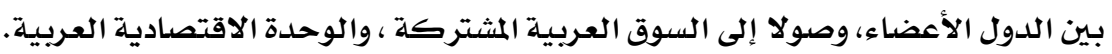

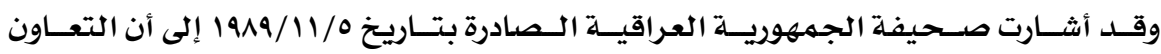

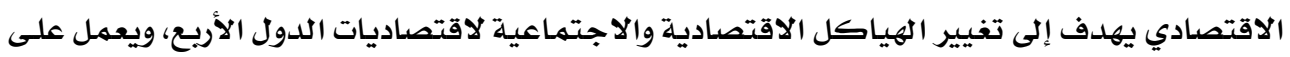

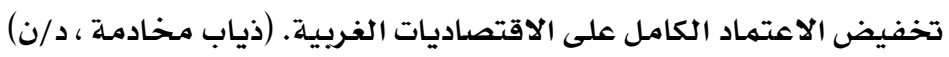

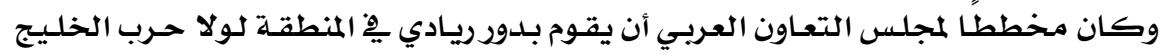

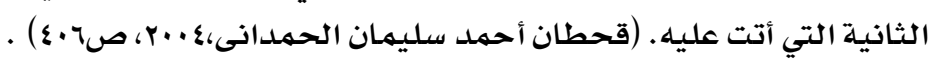

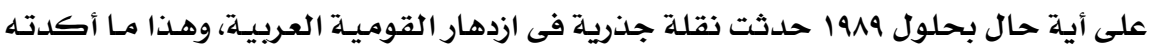

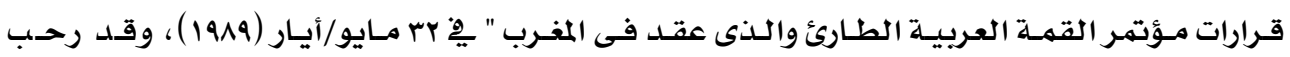

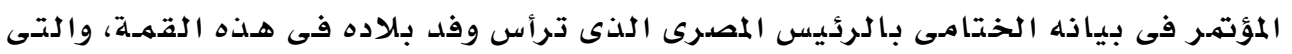

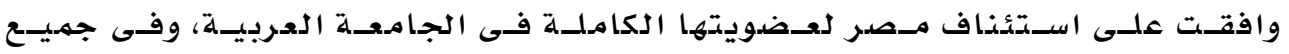

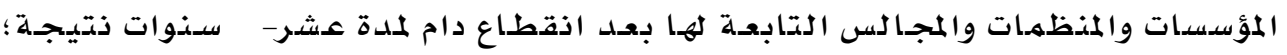

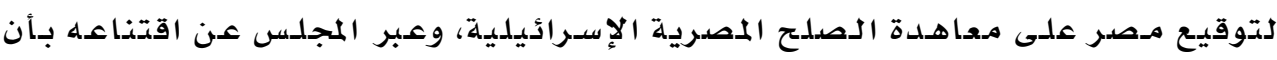

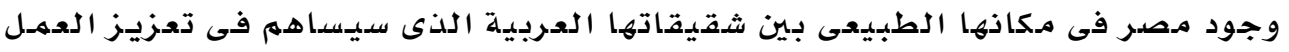


العبربى المشترك ويد اعم مسيرة التضدامن ووحدة الصف العبربى، وقد بحث المؤتمر التهديدات

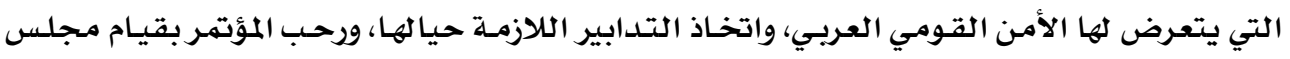

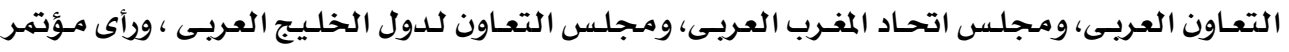

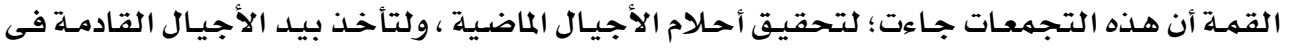

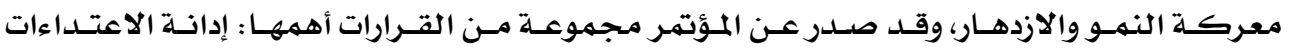

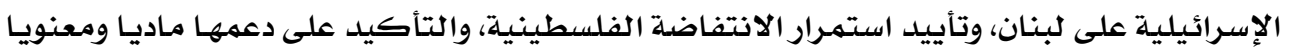

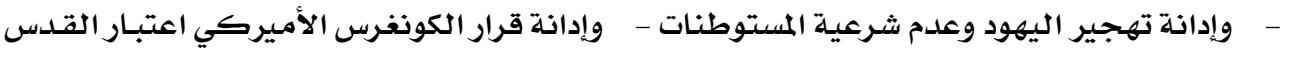

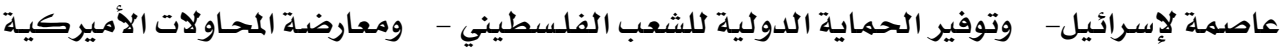

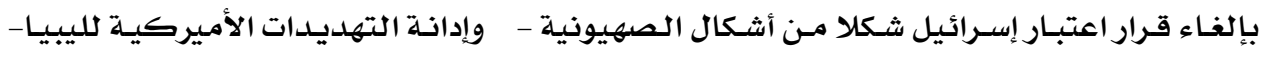

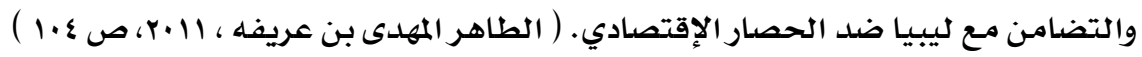

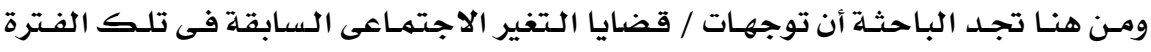

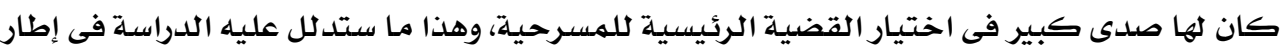
الآتى :

- من خلال حوار المسرحية التالى ندرك أن الكاتب حاول تغليف قضيته الأساسية بهـذه القضية

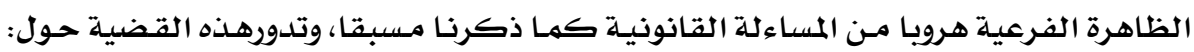

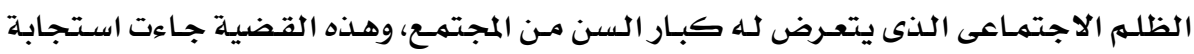

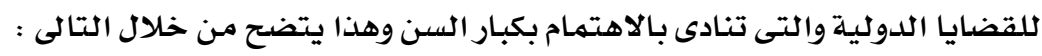

$$
\begin{aligned}
& \text { الأرنب : وافرضوا كان مقدرثى يحافظ } \\
& \text { كوكي: لا دا كان قتلله }
\end{aligned}
$$

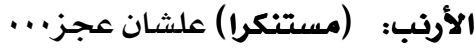

$$
\begin{aligned}
& \text { الفرخه: فيها حاجه ديء؟ }
\end{aligned}
$$

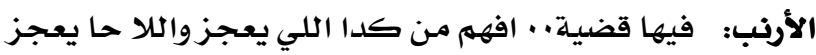

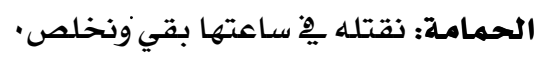

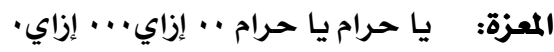

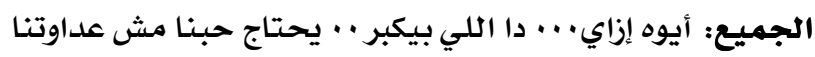

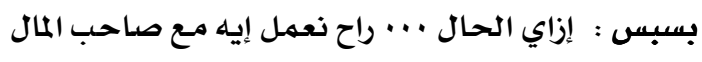

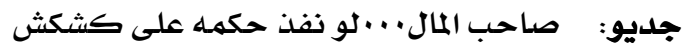

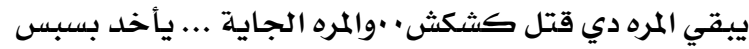

بسبس: (مشيره لنفسها) يعني احنا نديله عفيتنا وهو يأخد أعمارناوفايدتنا

الفرخة: والآخر

$$
\begin{aligned}
& \text { كوكي: (تلاحقها يِّ رنة بكاء) يقطع رقبتنا } \\
& \text { جديو: (مستنكرا) بقى دا اسمـه كلام }
\end{aligned}
$$


مجلة بحوث التربية النوعية - علد 7 ع - أبريل r.IV

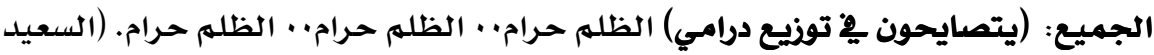

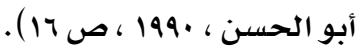

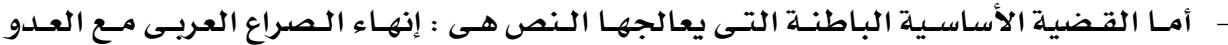

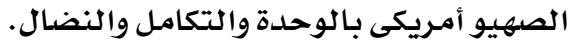

وترى الباحثة أن المسرحية قد اعتمـلـت على التفسير التاريخى ؛ للتنظير لسياسة النظـام

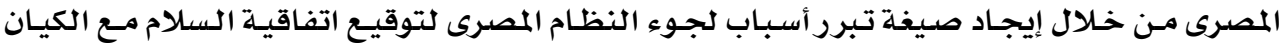

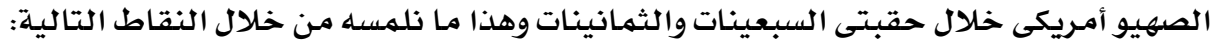

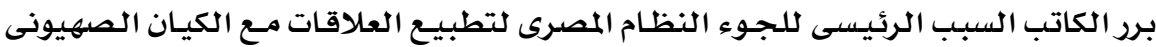

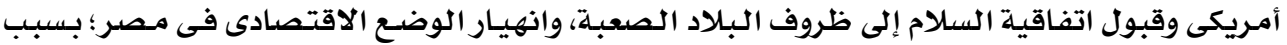

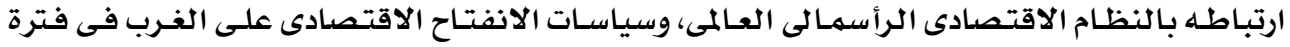

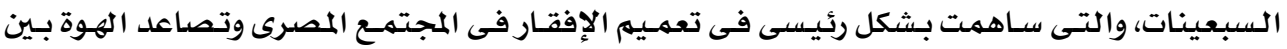

طبقات المجتمحع، وتصاعد المعارضة والانتفاضدة الشعبية ضد النظام السياسي والحكومـة المصرية. وفى هـذا الـصدد يؤكـد تقريـر التقيـيم الشـامل الـذي أعـدّ عـن مـصر لعـام 19VV، مـن قبـل

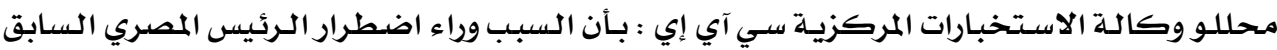

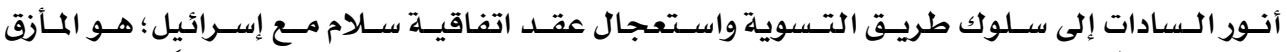

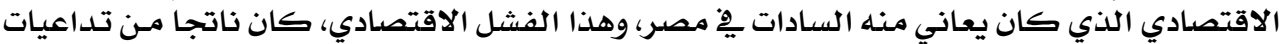

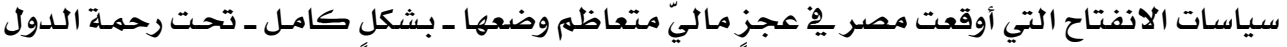

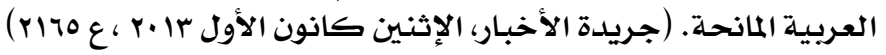

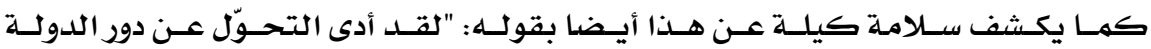

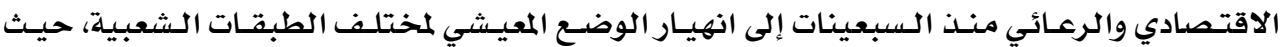

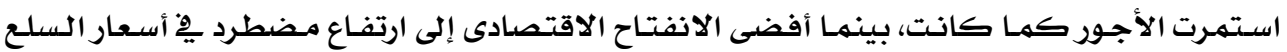

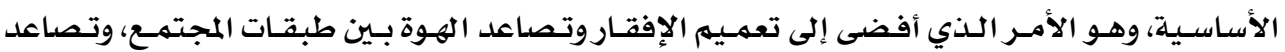

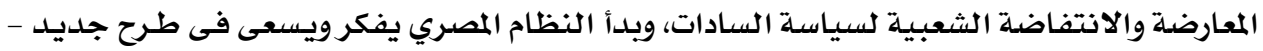

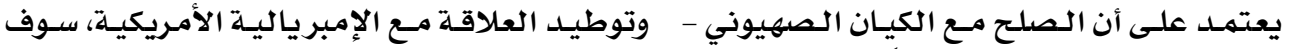

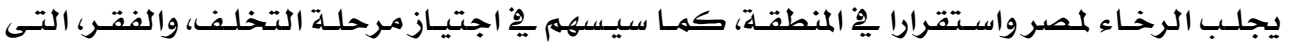

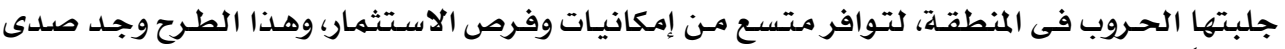

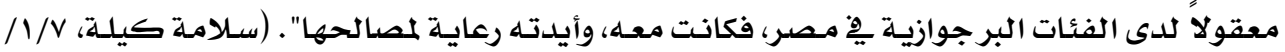
(http://www.ahewar.org/debat/s.asp?aid=240864\&t=4 r.ll

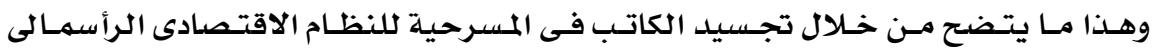

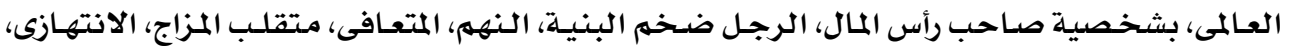

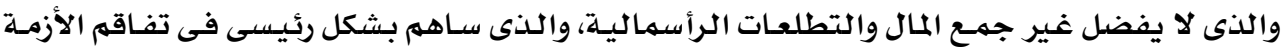

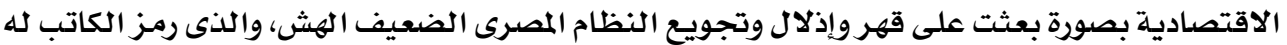


بشخصية الكلب كشكث العجوز الطيب الهادئ الفقير والذى يرضى بأقل القليل كنايـة عن ضعف

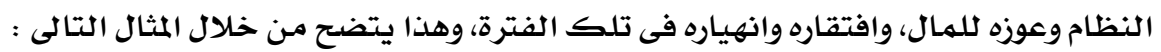
(حجرة بها ترابيزة يجلس صاحب المال يأكل بشراهه كشكش يجلس على الأرض يمسيح

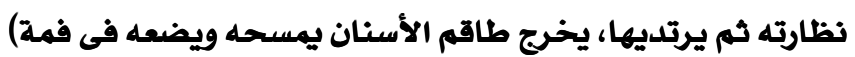

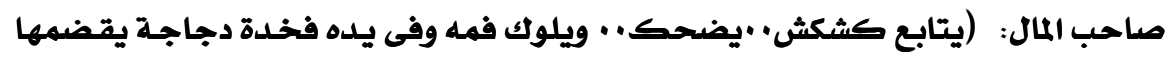

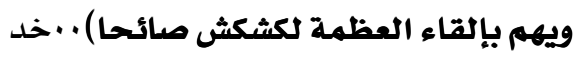

كشكش: يقف على ساقيه ويهم بالتقاط العظمة باسما ويهز ذيله قائلا) شكرا صاحب المال : (يغضب فجأة ... يدفع كشكث بقدمه بعنف فيسقط على الارض .. تسقط

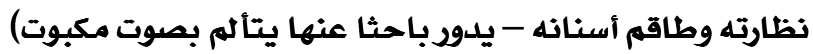

صاحب المال: (أثناء ذلك يضحك شامتا ..ويضع العظمة فالطبق أمامه ) لا دا أنت خسارة فيك العظمة ولاعاد لك هيبـه ولا كلمـة نظارة طبية وطقم أسنان دا ما عدش يجوز فيك الإنسان

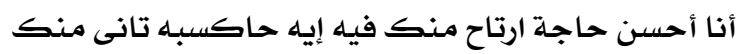
لو شفت الحرامية حاتهرب آخدلك وأخلص منك بلدري إمشى إمشى ما بنوكلشى عندى سلاحى حاديك بالنار إمشى إمشى ما بنوكلشى إمشى إمشى ما بنوكلشى

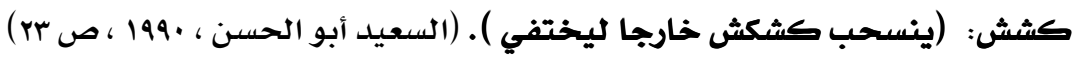

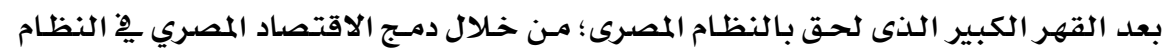

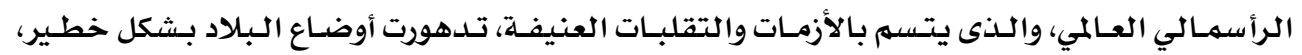

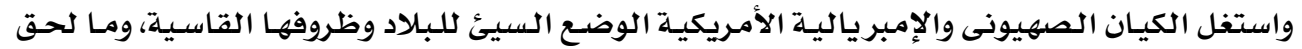

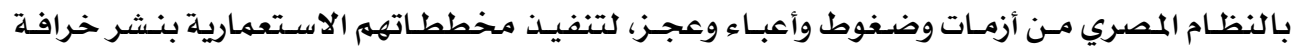

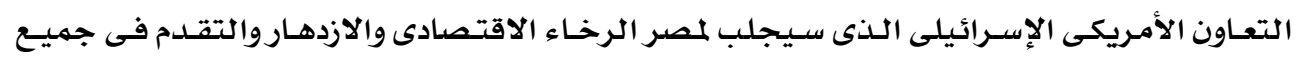

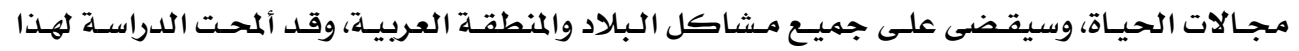

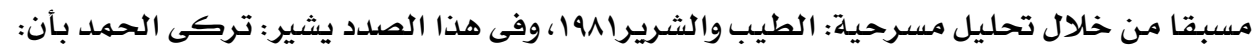

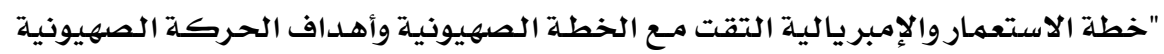

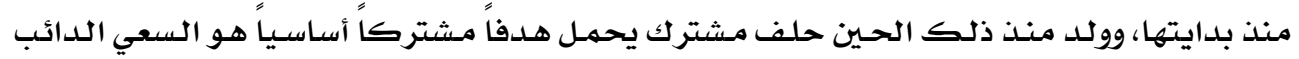

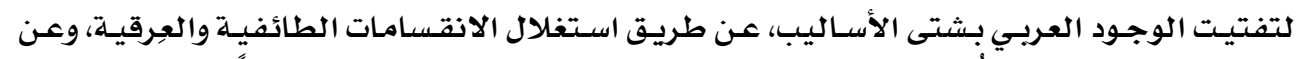

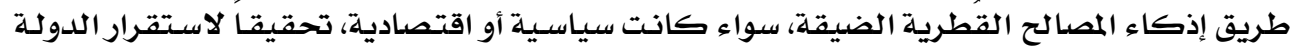

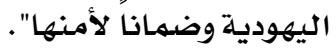
(/https://arabcenter.wordpress.com، تركي الحمد، د/ن) 


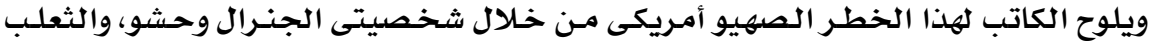

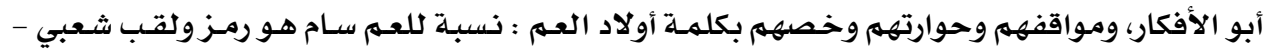

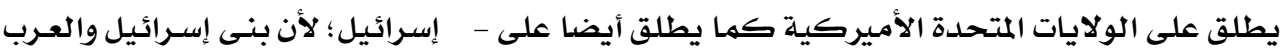

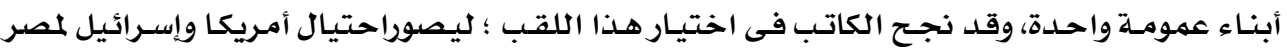

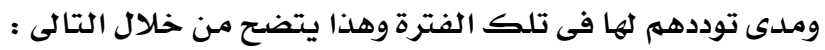

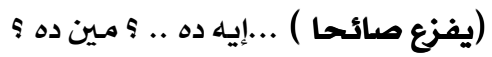
كشكث : كرئ

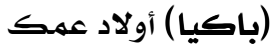

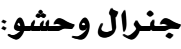

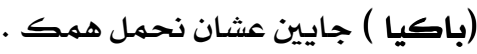

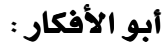

إيـا ده سيبونى فى حالى اهئ

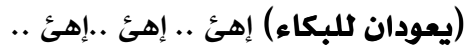
كشثش : الإثنـين : (فى حذر) إمشو فى حالكم سيبونى فى حالى إنى ) (مستنكرا) ده أنت قريبنا واخوانا الغالى (ملى كشثش : وحشو : قلبى عليك .. زعلان متأثر أنا متتشكر قوى متتشكر على إيه دا احنا أخوات فى الضيق دانا لما سهعت إن أم قويق بتنعى

قهنـا شتهمناها بالذمة أيى والله أمـانه ...

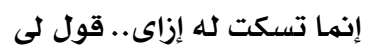
وراح أعمل إيـه طيب قولى أنى أقول لك (يتلفت حوله ففى حذر) حارسهم لك خطة فنية فنية ؟ أ

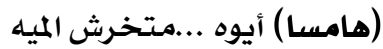
(مستتنرا) فنيـة إيـه يا بو الأفكار

مانتث شايفه ... إزاى مححتار دا يا عينى لا عافية ولاقوة مـاهى هيـ المشكلـه فى القوة لو صاحب البيت شافه فتوة

(السعيد أبو الحسن، • 199، ص. 1).

راح يرجح عن قتله ضرورى .
أبو الأفكار :

كشثش : كو

أبوالأفكار :

وحشو :

الإثنين : ولئو

: كشكش

الإثنين : ألم:

أبو الأفكار :

كشکشث:

أبو الأفكار :

وحشو :

أبو الأفكار :

وحشو :

أبو الأفكار :

وحشو :

أبو الأفكار :

يصر الكاتب مـرة أخري على أن أمـريكا وإسرائيل كبلوا النظام المصري بسببـ محنته وعوزه، وورطوه فى عقد اتفاقية كامسب ديفيــ 9VA اوإتفاقيـة السـلام 19V9، كهـا أنهـم خـدعوه بوعود كاذبـة 
وأوهـام غير حقيقيـة؛ لتحقيـق مصـالحهم الاستعمارية فى المنطقـة العربيـة، وبالفعـل هـذا مـا أكـده

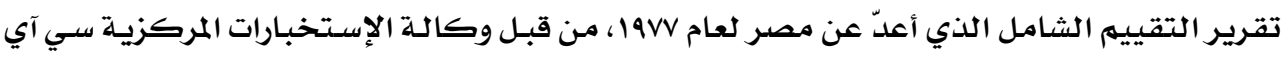

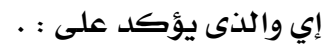

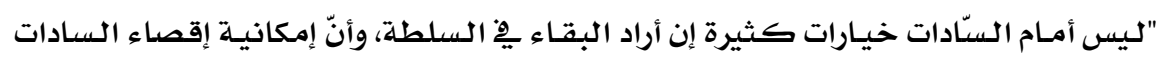

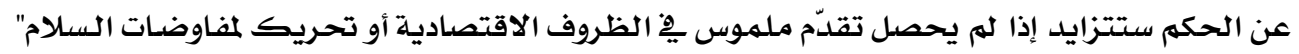

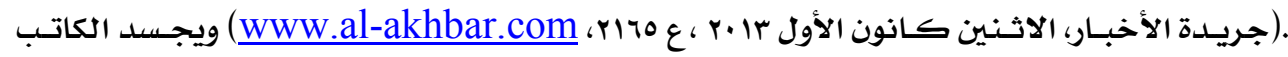

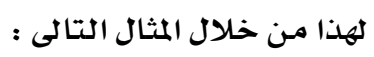

كشكش : (كان يراقبهما فى حذر) وتمنها إيه الفكره دى ؟؟ الإثنين : وكأنما قد كشف أمرهما فيهمهمان فى استنكار مصطنع) إيها ؟

أبو الأفكار: كشكث عيب تجرح إحساسنا

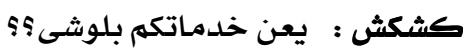
أبو الأفكار: أخونا زيك ما نطلبوشى . ..فتح ودنك للى حقوله وحشو : : اسمـع وافهم كشكش : طيب قولوا وحشو : اسمع وافهم لاتفاقية

$$
\text { كشكش: اتفاقية ؟ }
$$

أبو الأفكار : أيوه اتفاقية جنتيل أنهل ما تتخضش دا كلام حايفيدك مايضرش

(يخرج من جيبه قطعة عظم قديمة يقرأ منها )

إنه فى تاريخنا المتأكد اجتمعح أنا والوحش وكشكث فئه

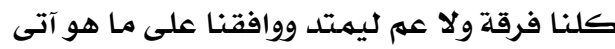

$$
\text { وحشو : واحد }
$$

أبو الأفكار : إنقاذ كشكث فورا واعادته لمكانته الأولى

$$
\text { وحشو : اثنين }
$$

أبو الأفكار : (مكملا) بعد ما نتاكد ..ونأكد عودته لمكانته من تانى

$$
\text { وحشو : ثلاثثة }
$$

$$
\text { أبو الأفكار : يبقى لينا كلام تانى }
$$

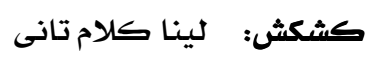

أبو الأفكار : امضى يا كشكث: (السعيد أبو الحسن ، •199 ، ص r|) 


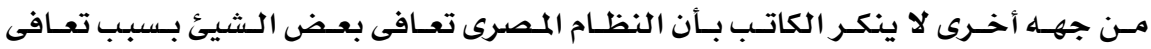

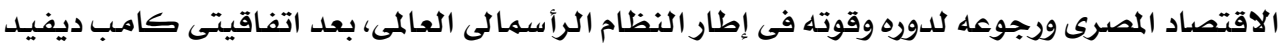

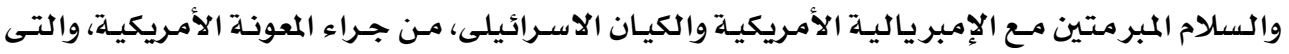

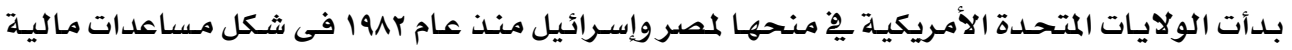

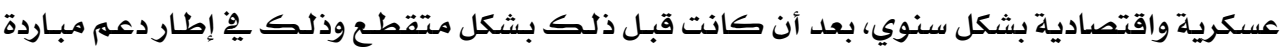

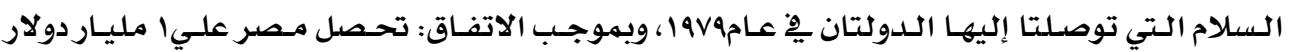

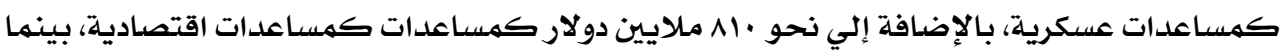

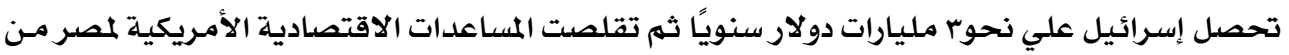

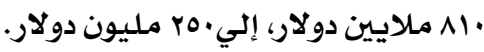

( http://gate.ahram.org.eg/News/173574.aspx،r.lr، فاطمة منصور )

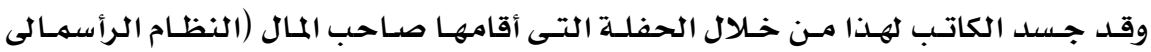

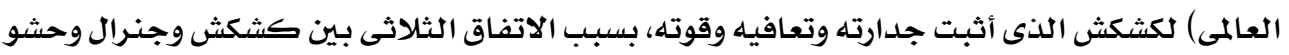

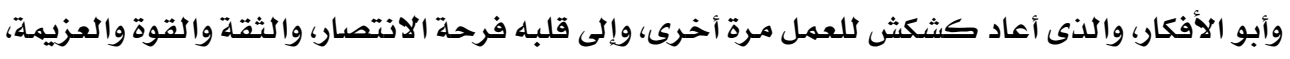

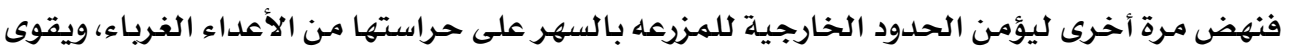

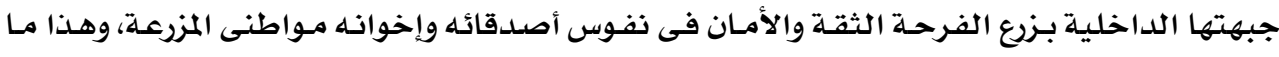
يتضح من خلال التالى :

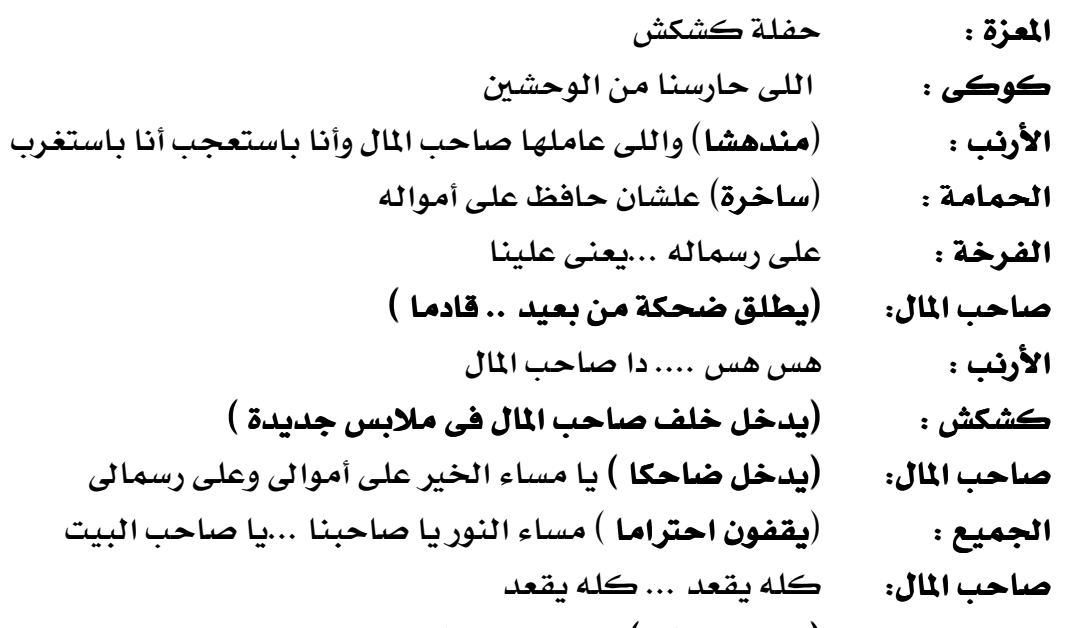

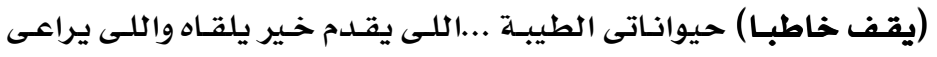

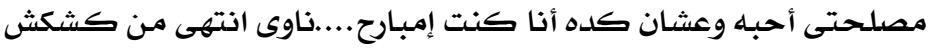

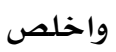
كنت زمانى من الأموات .أنا لما التعلب فات كشكث :

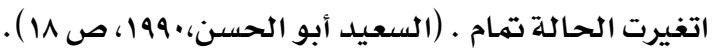

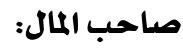




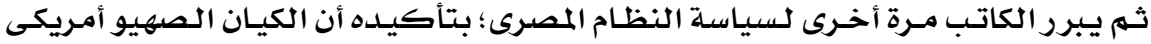

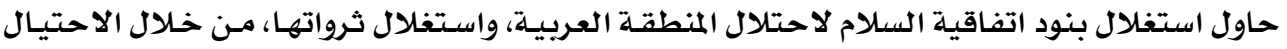

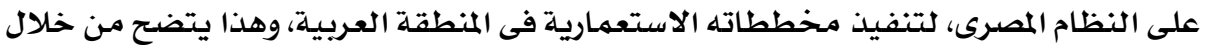

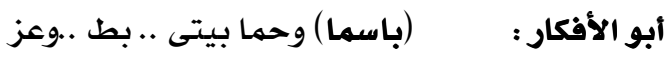

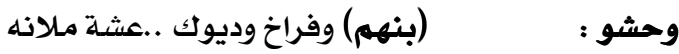

$$
\begin{aligned}
& \text { قوم هات لنا حاجـة قوم فز وفرد }
\end{aligned}
$$

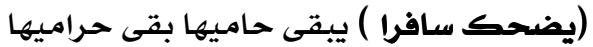

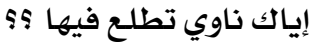

مبلاش لاستعباط ده علينا

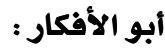

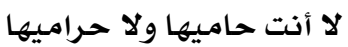

لا دنا حميها ولازم أحميها

كشكش:

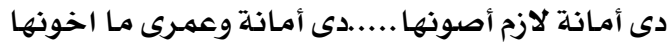

كش يا كشكث بص لنفسك

(يصيح غاضبا) دا احنا عملناك تانى ياكشكث لفيك

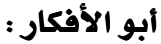

وحشو :

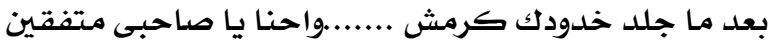

متفقين على إيه قولى جلى

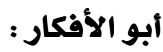

عيب تخدعنا وإنت فى سنك

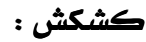

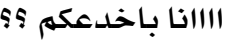

أيوه أمال دى إتفاقية جنتل أنمل

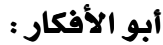

كشكث:

الإثنين :

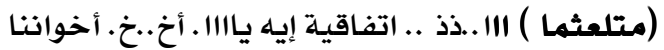

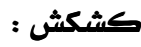

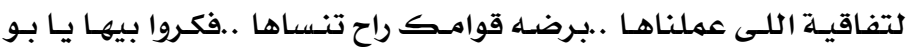

وحشو :

الأفكار

إنه بالأمس المتأكد .. إجتمع أنا والوحش وكشكث .. كلنـا فرقة ولا

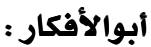

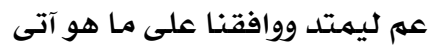

وحشو :

إنقاذ كشكث فورا وإعادته لمكانته الأولى

إتنين

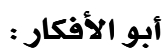

بعد ما نتاكد ونأكس عودته لمكانته من تانى

وحشو :

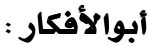

$$
\begin{aligned}
& \text { ثلاثة } \\
& \text { يبقى سـاعتها لينا كاملام تانى } \\
& \text { أيوه صحيح دا البند التالت }
\end{aligned}
$$$$
\text { وحشو : }
$$

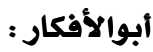$$
\text { كشكش : إنار: }
$$

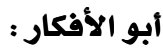




$$
\begin{aligned}
& \text { وعشانا كل ذيلة وليلة } \\
& \text { وحشو : }
\end{aligned}
$$

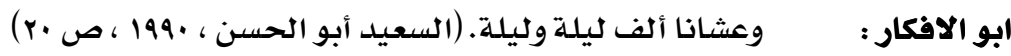

واستكمالا لسياسة التنظير والتبريـر، يؤكس الكاتب أن النظـام المصرى رفض خيانـة الأمسة

وفضل الموت فى سبيل الدفاع عن العروبة، ويظهر هذا بوضوح في لئير المثال التالى :

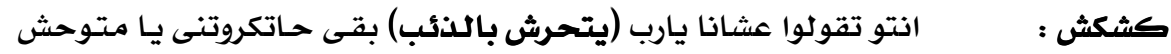

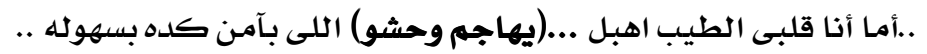

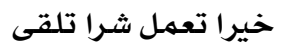

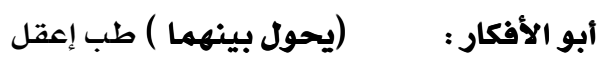

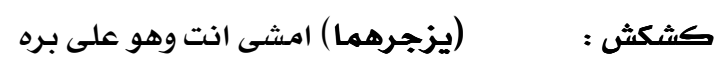

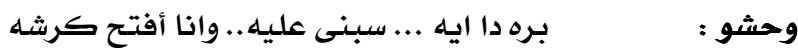

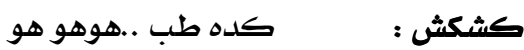

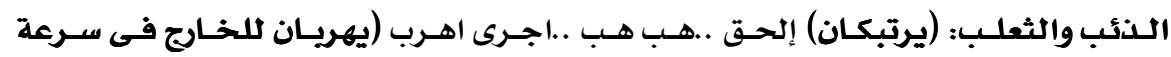

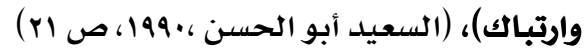

مـرة أخـرى نجـــ الكاتـب السعيد أبـو الحسسن يسعى إلى فضـح السياسـة الـصهيو امريكيـة

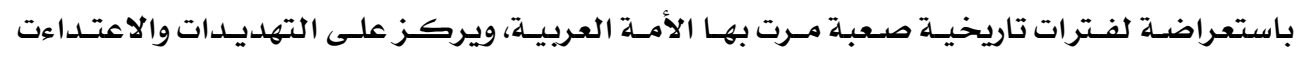

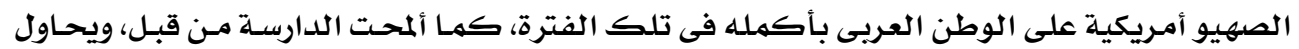

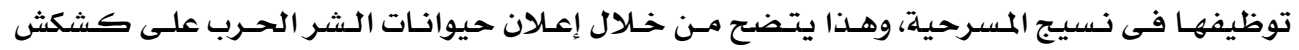

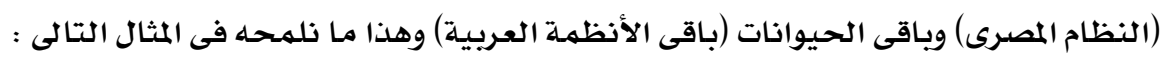

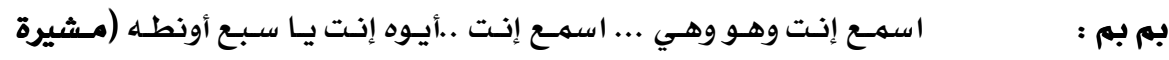
(كشكش).

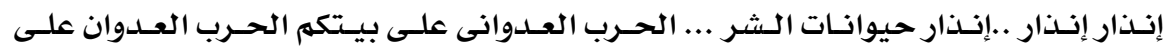

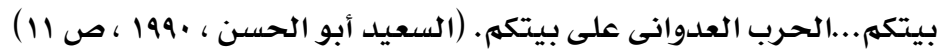

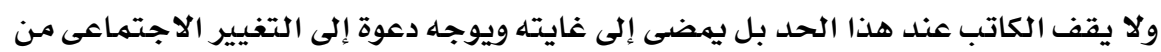

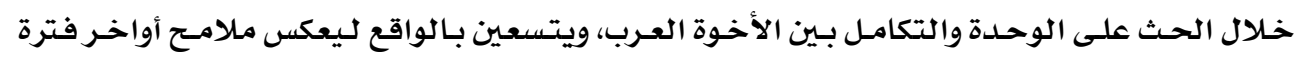

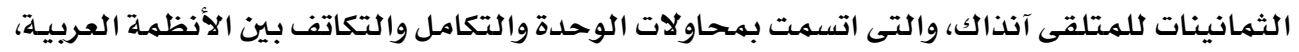

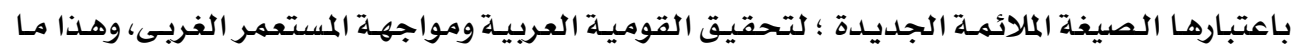

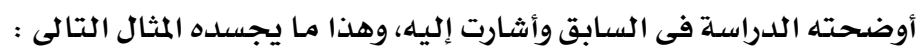

\section{(همهمات - همس ومشاورات)}

يا جماعه قاعدين من سماعه اهدوا عشان نعرف نتكلهم

الموقف يا جماعه خطير اهدوان نعرف نئرل

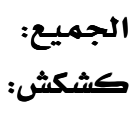

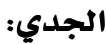




$$
\text { علشان كده عايزين تفكير }
$$$$
\text { كشكث: }
$$$$
\text { والتفكير آخره التدبير }
$$

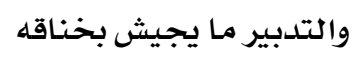

$$
\text { المعزة: }
$$

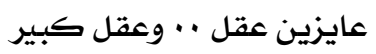

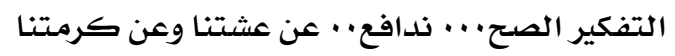

عن كل رملاية ِيخ بيتنا

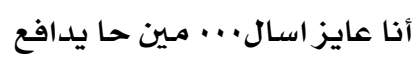$$
\text { الجدي: }
$$$$
\text { كشكث: }
$$

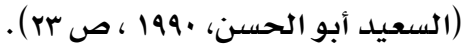

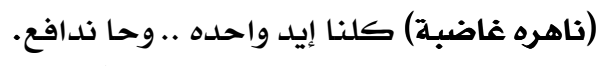

$$
\text { الأرنب: }
$$

بسبس:

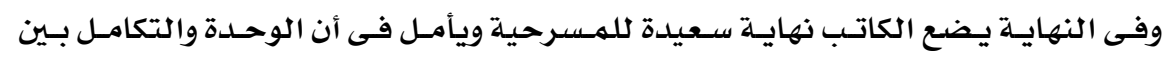

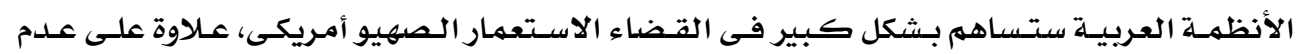

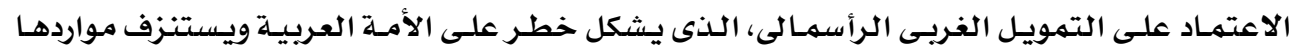

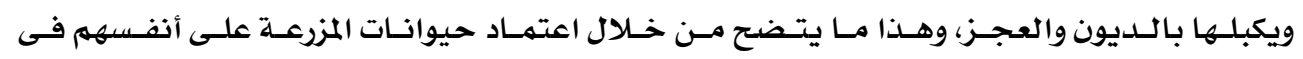

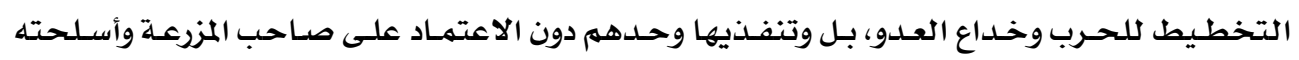

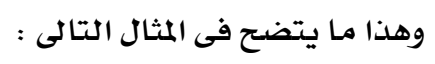

(تلدخل كل من كوكى والأرنب ومعهما صندوق وقد غطى بقطعة من القماث يفتح بابه

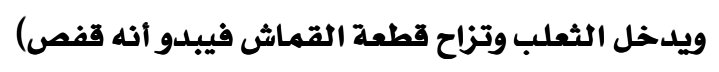

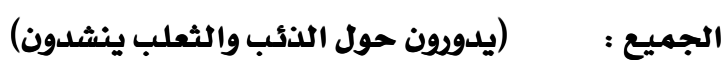

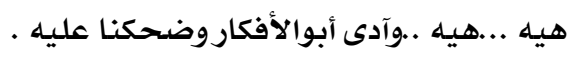

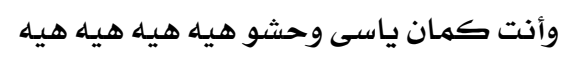

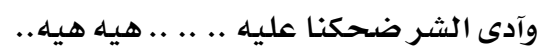

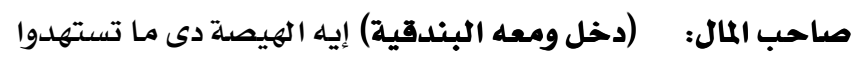

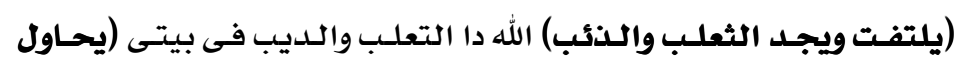

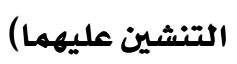

$$
\begin{aligned}
& \text { كشكش : لصاحب المال) التعلب والديب اتهلدوا } \\
& \text { والشر أهو استلقى وعدوا } \\
& \text { صاحب المال: والبر كة فى كشكث }
\end{aligned}
$$

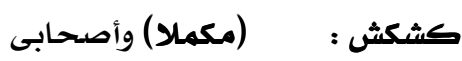

صاحب المال : تعالى لى يا كشكثل وأهيابى يا حبيبي يا حامينى يا منور بيتى

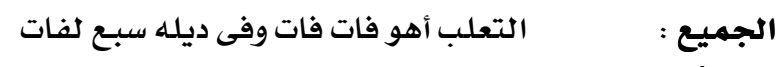

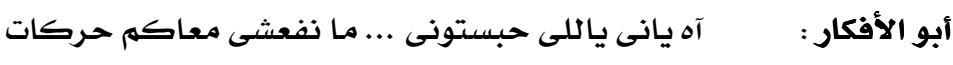

$$
\begin{aligned}
& \text { التعلب أهو . فات فات اتل } \\
& \text { الجميع : الجوال }
\end{aligned}
$$




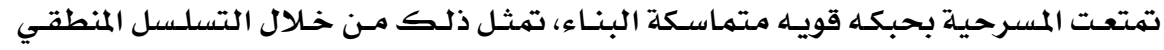

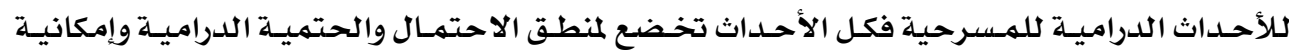

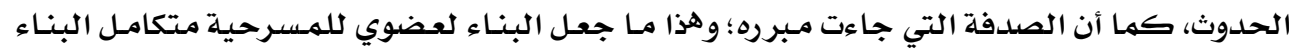

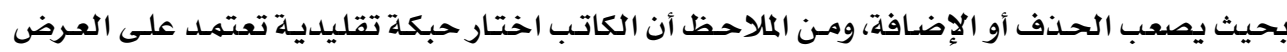

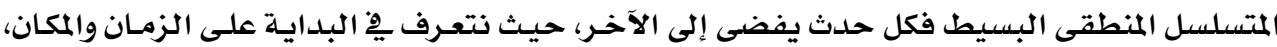

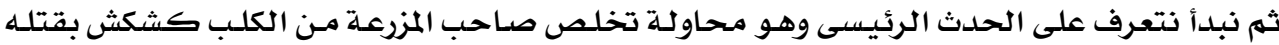

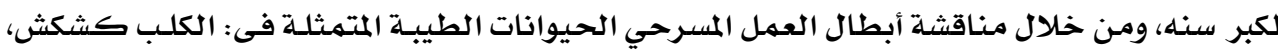

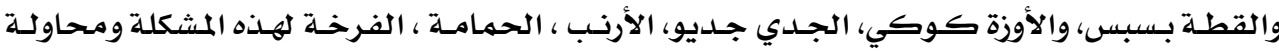

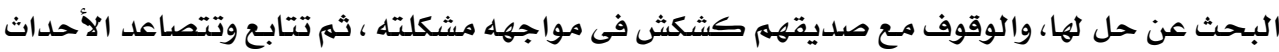

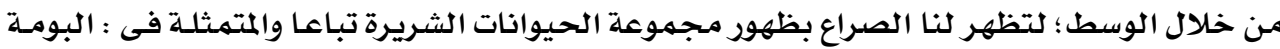

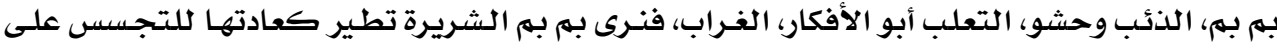

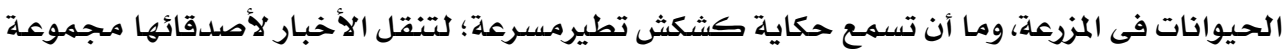

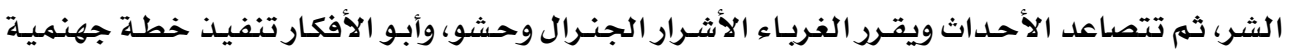

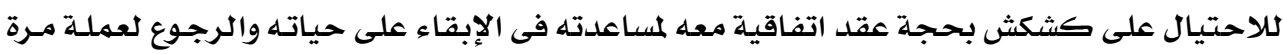

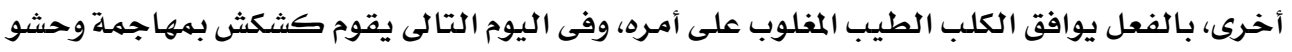

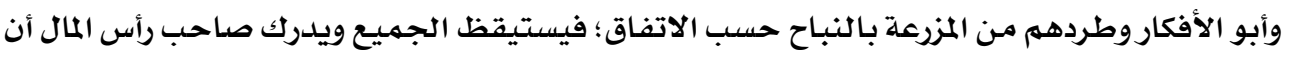

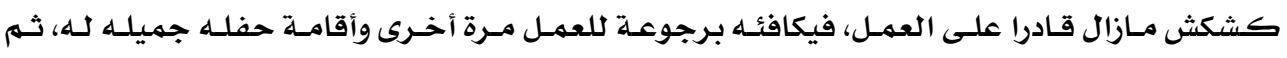

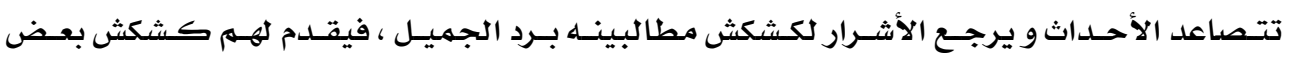

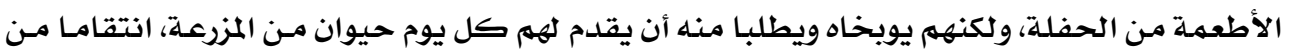

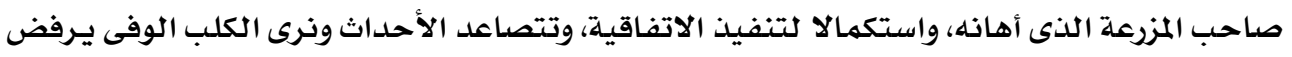

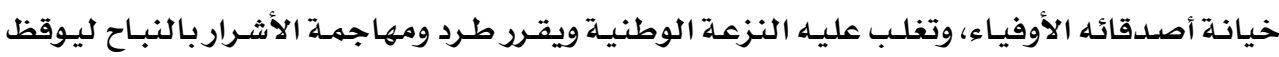

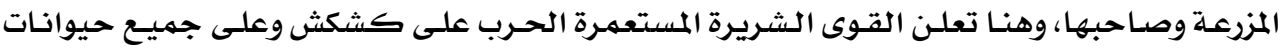

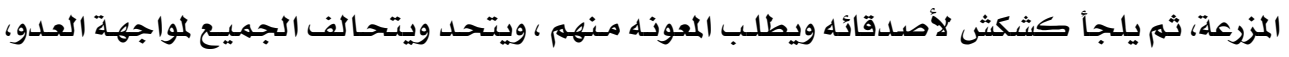

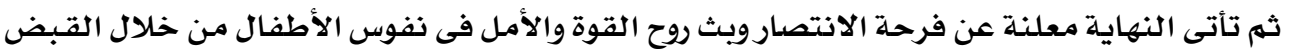

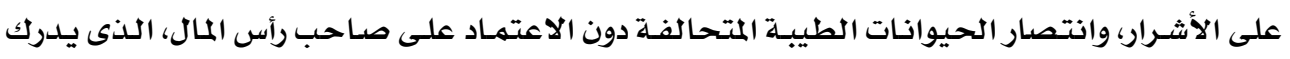

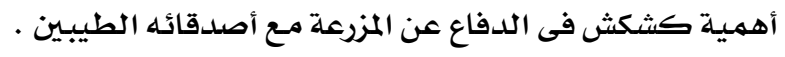


اعتمد المؤلف فى اختيار شخصياته على نهاذج مكونة من خليط من الشخصيات العرائسية

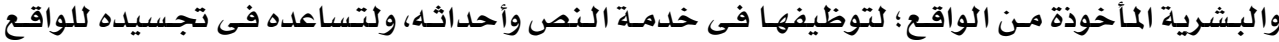

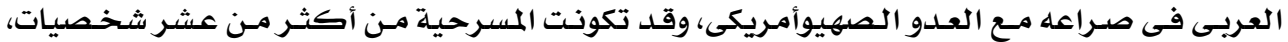

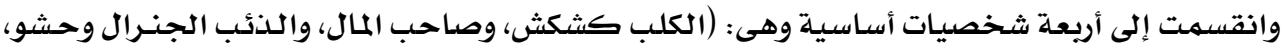

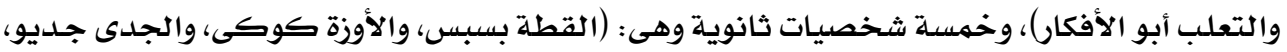

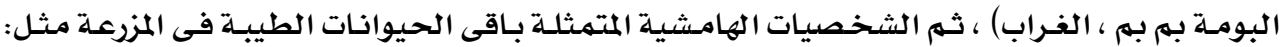

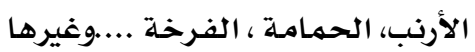

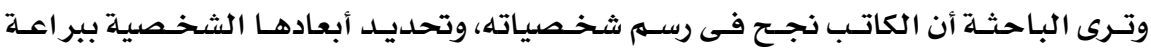

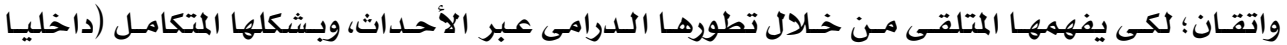
وخارجيا ) فضلا عن دورها فى تعميق الحدث الدرامى المتأزم وصولا إلى الحل النهائى للموضهوع، كمها

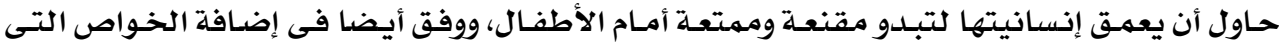

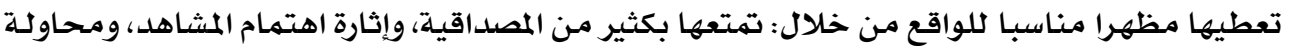

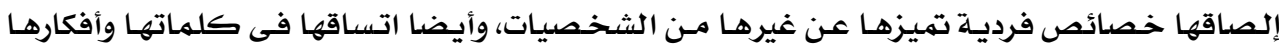

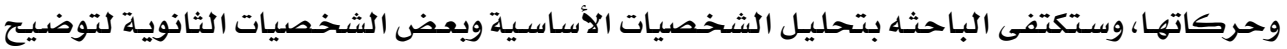

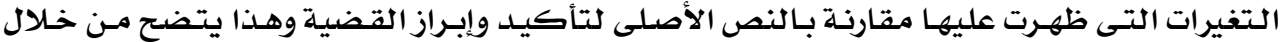

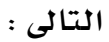

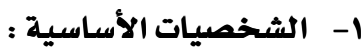
-

ألبس الكاتـب هـذه الشخصية دور البطولـة، وترى الباحثـة أن الكاتب اختـار هـذه شخصية؛

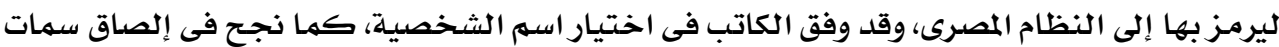

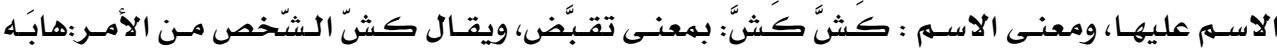

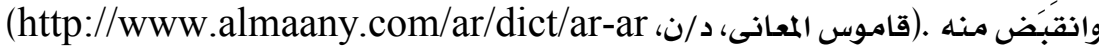

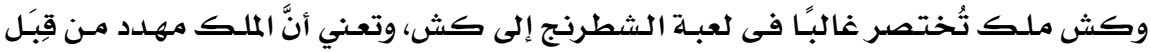

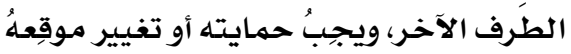

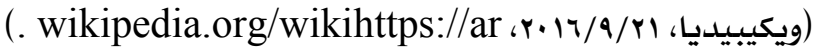
ومن هنا ترى الباحثة أن دلالة الاسـم توحى بترويـع وتحجيهم الأعداء وإخـافتهم وتهديداندهم

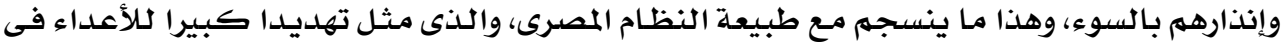

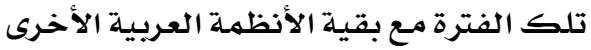

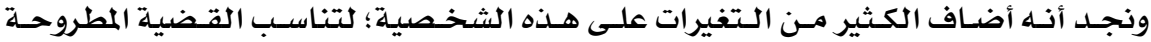

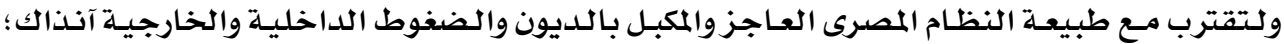

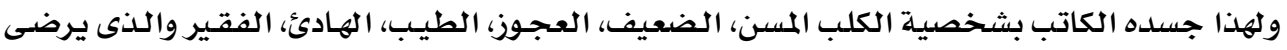


بأقل القليل، ولكنه صاحب حضارة وعراقة ومخلص لأصسدقائه ومحسب لهمه، كما أنه كـريهم وشـاع، بخلاف المأثور الشعبى والذى لهم يظهر هذه الصفات هلئ على الإطلاق.

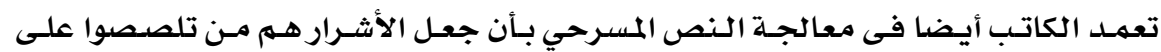

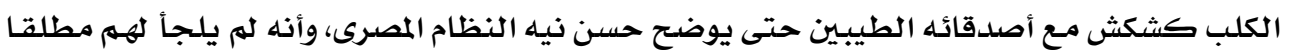

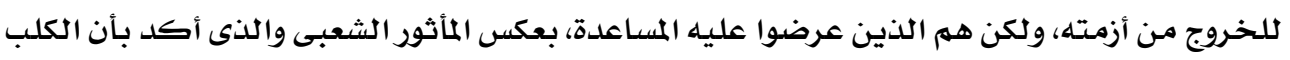

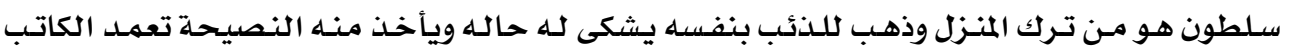

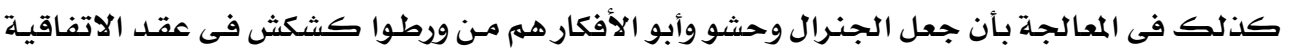

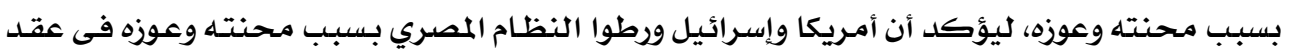

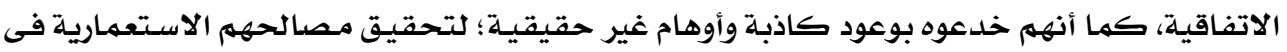

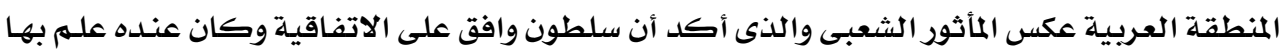

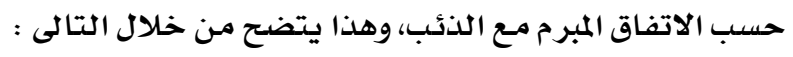

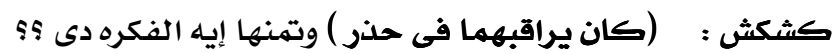

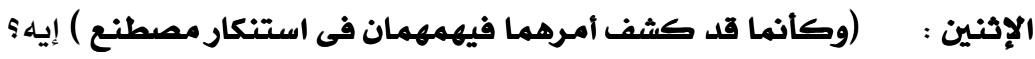
أبو الافكار: كشكث عيب تجرح إحساسنا

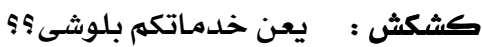

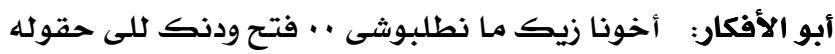

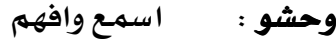

$$
\begin{aligned}
& \text { كشكث : طيب قولوا } \\
& \text { وحشو : اسمـع وافهم لتفاقية } \\
& \text { كشكش: إتفاقية ؟ }
\end{aligned}
$$

أبو الأفكار : أيوه اتفاقية جنتيل أنمل ما تتخضش دا كافيه كلام حايفيدك مايضرث

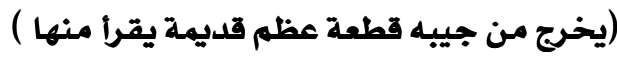

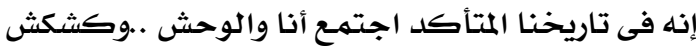

كلنا فرقة ولا عم ليمتد ووافقنا على ما ها هو آتى آنى أنى

وحشو : واحد :

أبو الأفكار : إنقاذ كشكث فورا وإعادته لمكانته الأولى

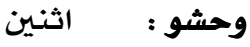

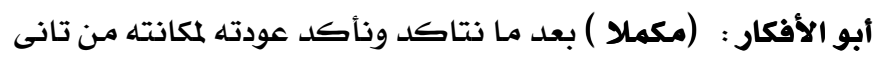

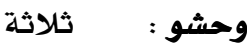

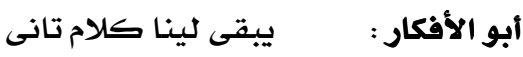

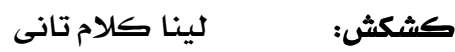

أبو الأفكار : امضى يا كشكث... امضى يا كشكث 
امضى يا كشكث. .. امضى يا كشكث . (السعيد أبو الحسن ـ التعلب

وحشو:

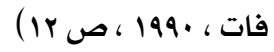

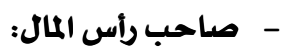

وهـو شخصية مـضادة للبطل، وترى البـاحثة أن الكاتب وفق في اختيـار اسـهم الشخصية :

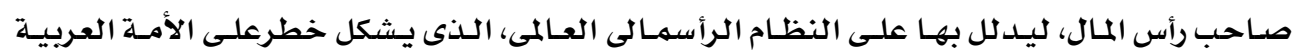

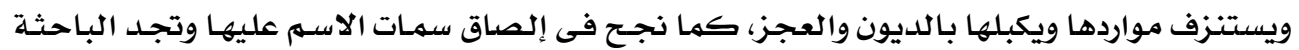

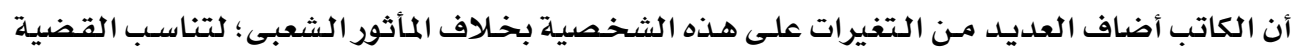

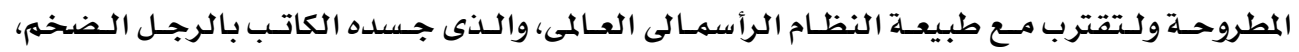

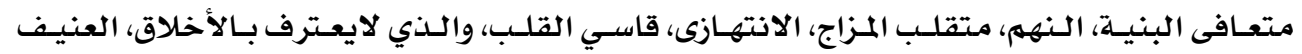

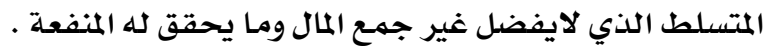

-

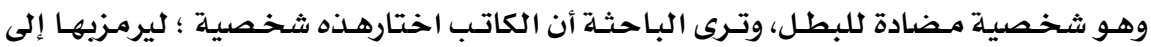

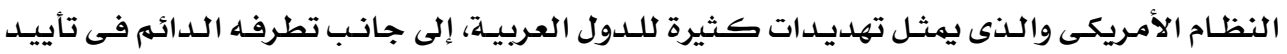

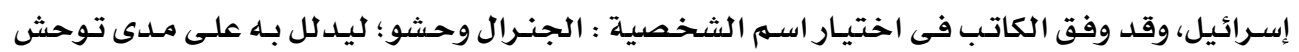

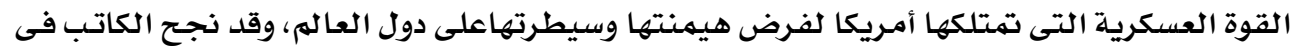

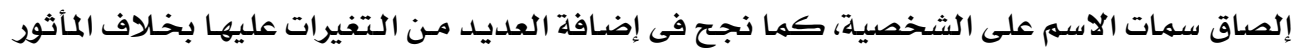

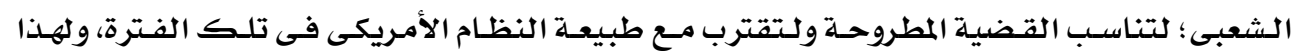

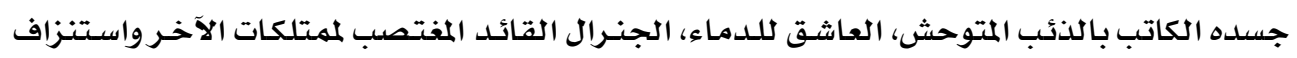

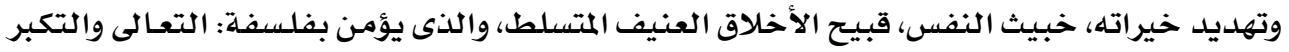

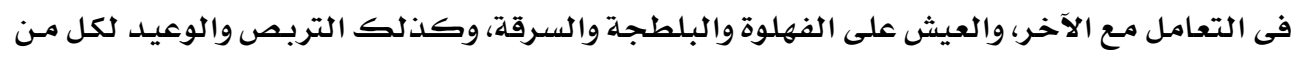

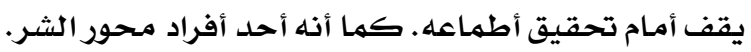

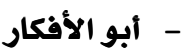

وهو شخصية مضادة للبطل، وترى الباحثة أن الكاتب أضـاف هـذه شخصية بخـلاف المأثور

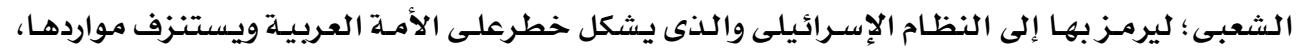

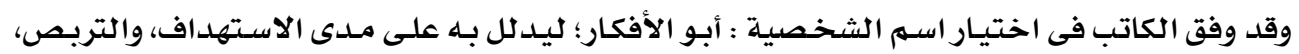

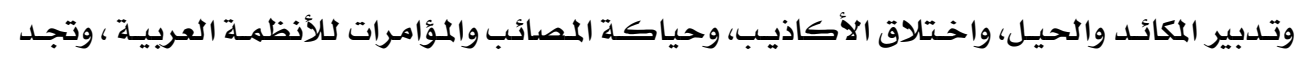

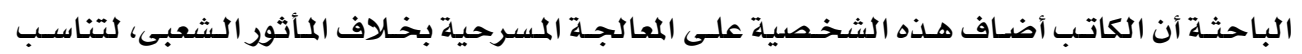

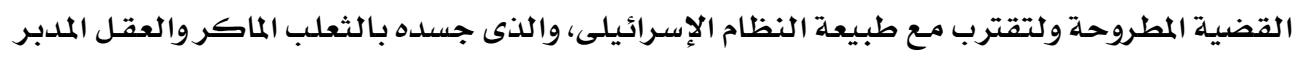

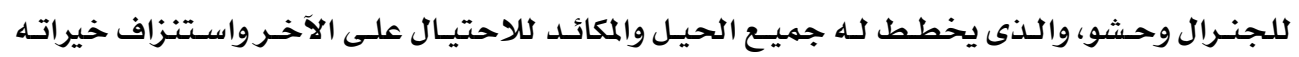

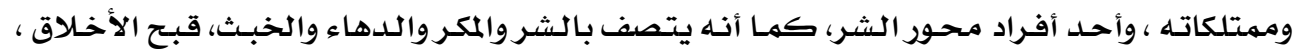

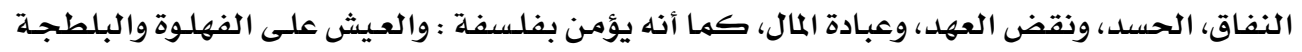
والسرقة. 


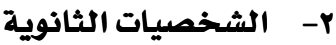

- الحيوانات الطيبة : القطة بسبس ، والأوزة كوكى، والجدى جديو : وقد اختارها الكاتب لتكون ثانوية أو مشاركة فى الحدث الدرامى، وترى الباحثة أن الكاتب

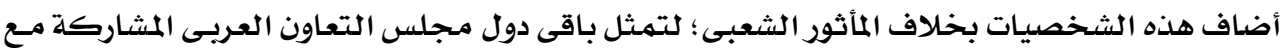

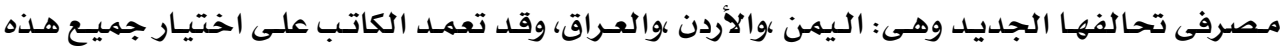

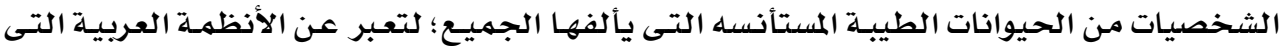

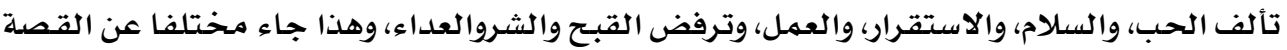

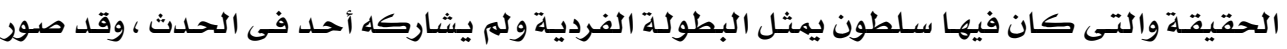

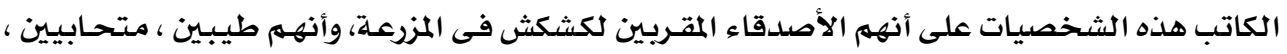

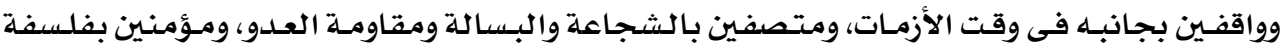

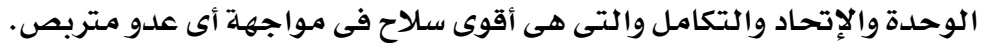
- الحيوانات الشريرة : البومـة بم به ،و الغراب:

وهى شخصيات ثانوية مشاركة فى الحدث اختارهـا الكاتب؛ لتمثل بـاقى شخصيات محسور

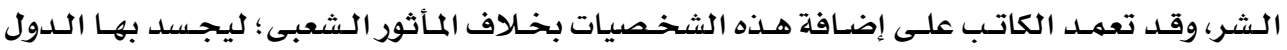

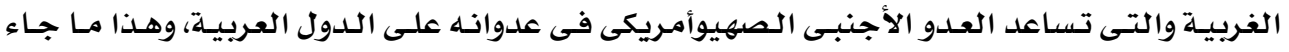

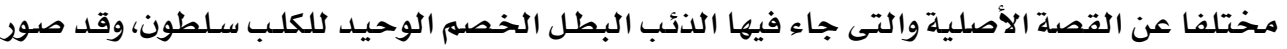

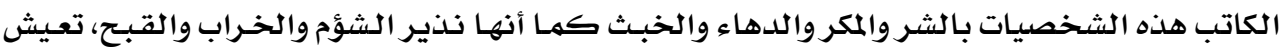

$$
\text { على السرقة واستنزاف خيرات الآخر }
$$

r- الشخصيات الهامشية

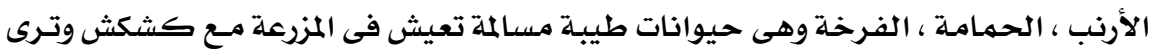

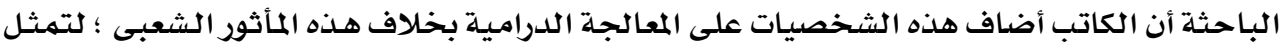
باقى الأنظمة العربية.

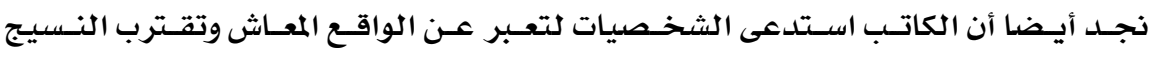

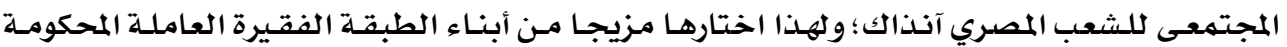

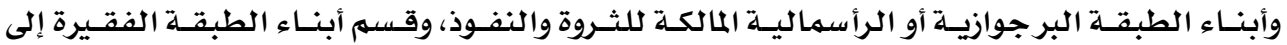

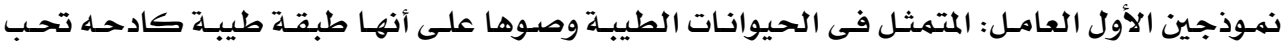

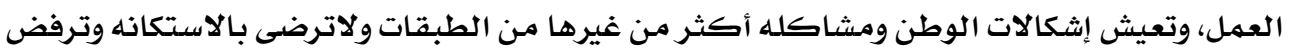

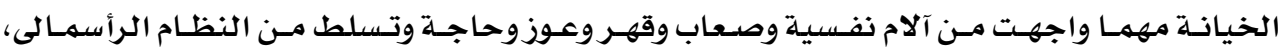

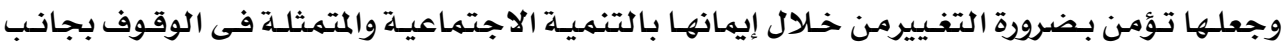

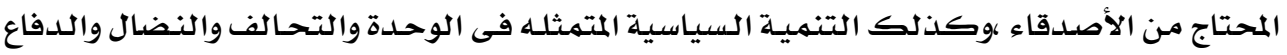

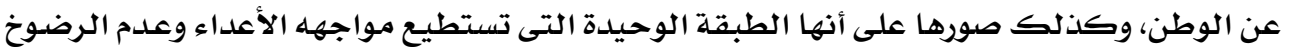


لعدوانهم ، وأن الأمل والوحدة والتكاتف والازدهار والتفـاؤل والتغيير ينبـع مـن بـين صفوف المجتهـدين

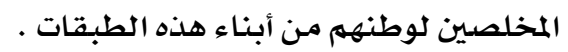

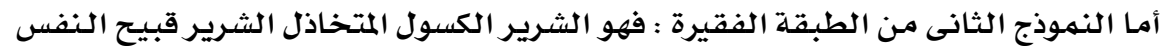

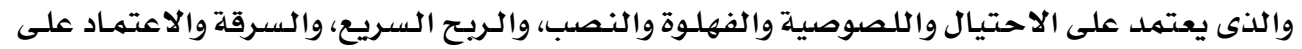

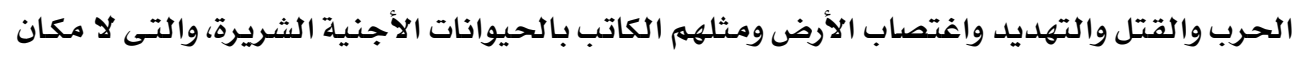

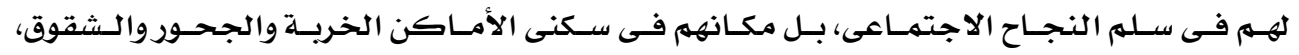

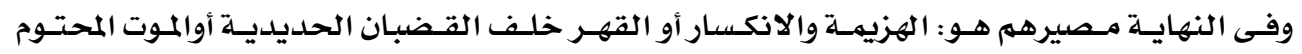
الغير شريف.

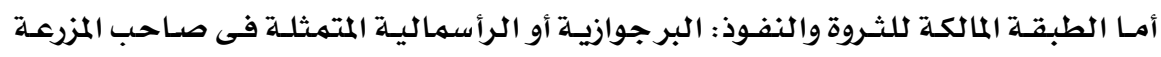

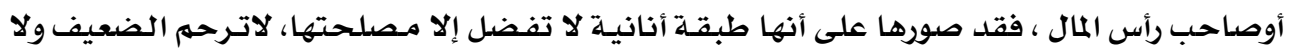

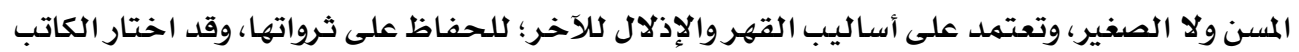

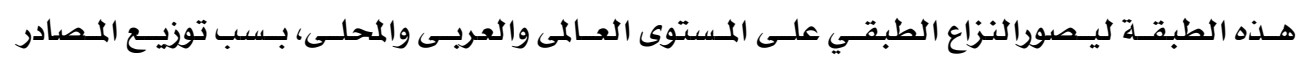

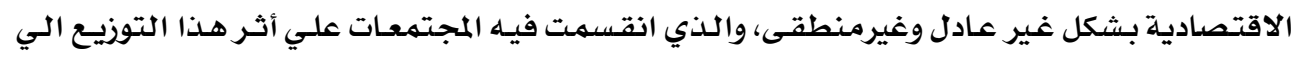

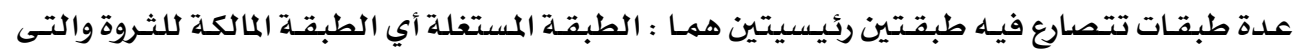

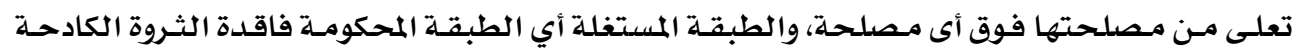

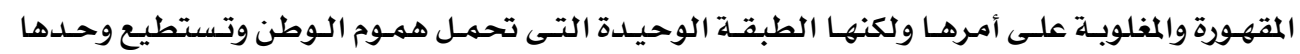

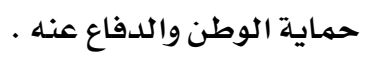

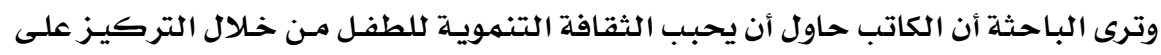

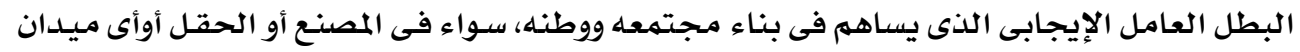

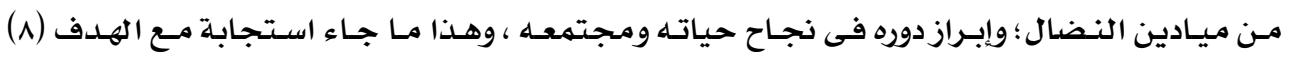

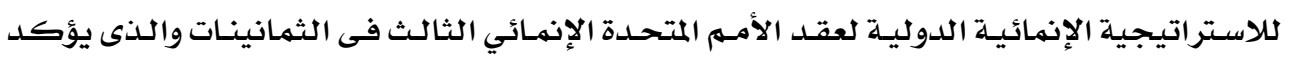

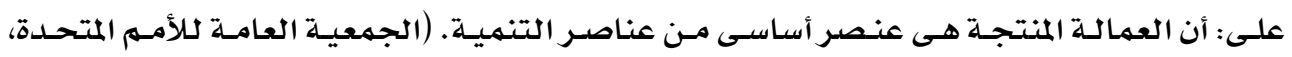

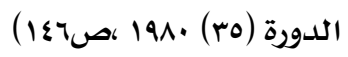

اللفة :

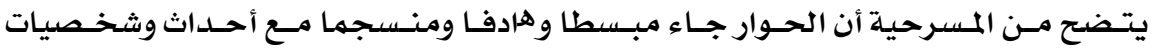

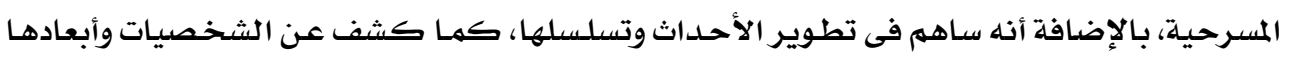

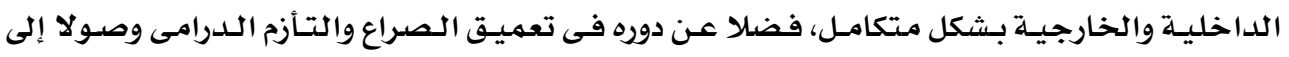

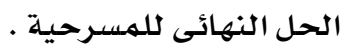
وكتبـه المؤلف بلغه رقيقه بسيطة وواضحة يْ مستوي استيعاب المتلقي، تقوم علي الطرافة

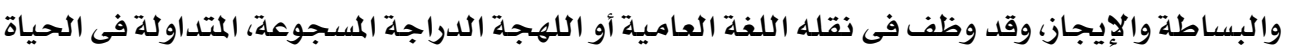

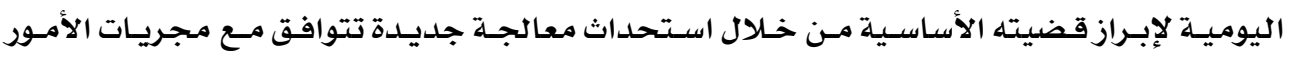

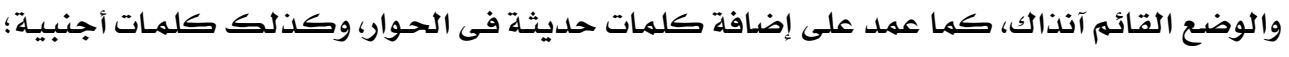




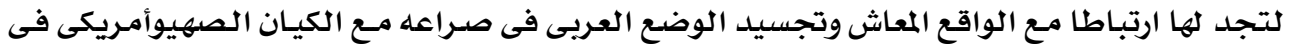
تلك الفترة، وهذا ما فصلته الدراسـة فى السابق. وقد حرص الكاتب على تقديم المسرحية مـن خـلال الأسـلوب الشعرى البسيط ، وفى قالب

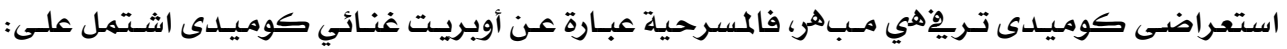

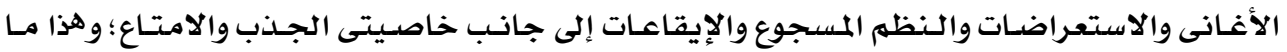

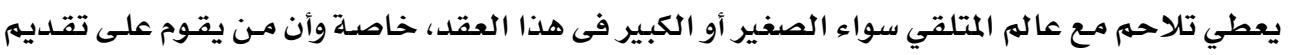

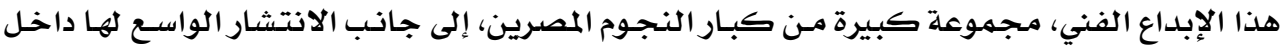

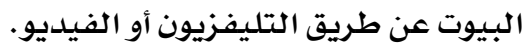

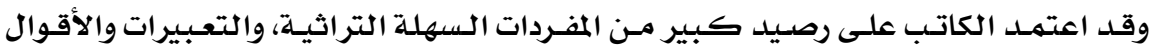

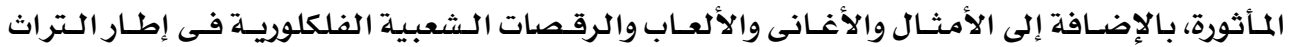

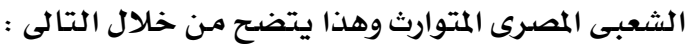

- - استلهام اسهم المسرحية التعلب فات: وهذا الاسهم يعبر عن أغنيـة أو لعبـة تراثيـة تقدم للأطفـال

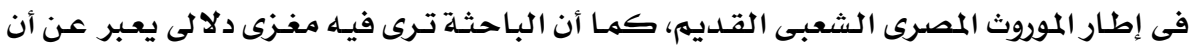

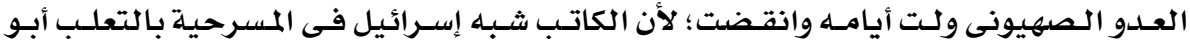

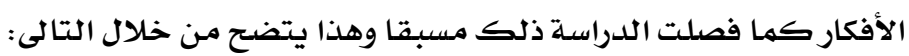
لكن ريك هد الظاله والمظلوم ريك وياه

والتعلب أهو راح فى أبو نكلـــــه

خدوا ديله لزقوه فى قفــــــــــاه والتعلب آهـــو فات ..... فات

وفى ديـــــله سبـع لفـــــــات

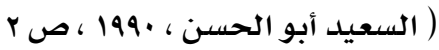

- استدعاء كلمات تراثية مثل: امشى انجر، أونطه، الله لا يسيئكم، مبلاش استعباط، اتهزيـاوز،

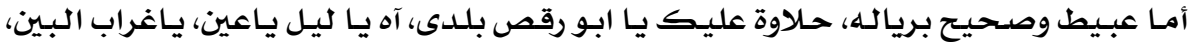

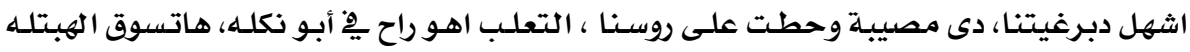

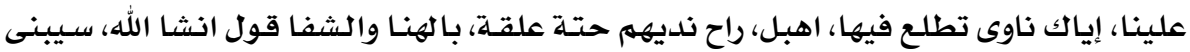

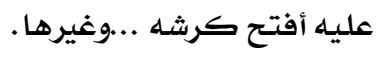

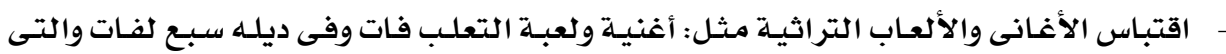

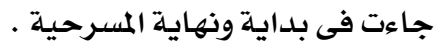
حيوانات الخير : التعلب آهو فات فات وفى ديله سبع لفات والديب السحلاوى معحاه اتفق التعلسب ويـاه 


$$
\text { كونوا فرقة شر كبيرة يامهم الديب والتعلب ياه }
$$

( السعيد أبو الحسن ، • 199 ، صمب).

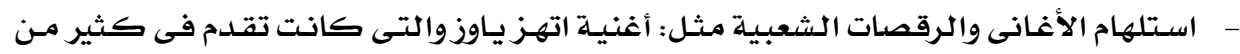

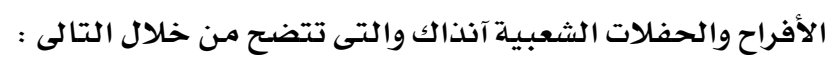

(يقدم كل واحد من الحيوانات بما استعد له .. الأرنب على الفلوت .ـوالمعزة على الطلبة ..

والحمامات على الصاجات )

$$
\text { ترترى الحزام بالترتر ( تستعد للرقص مع الاغنية) }
$$$$
\text { : كوكى : }
$$

اتهزيا وزوفرجنا ....ارقص بالبلدى وفرحنا

الحمامة :

الحفلة جميلة وليلتك ليلة .... الحفلة جميلة وليلتك ليلة

حلاوة عليك ياأبورقص بلدى اتهز يا وز....اتهز يا وز

حانغنى ياليل ونقول مواويل ..للى بيحرس لينا أرواحنا

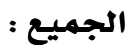

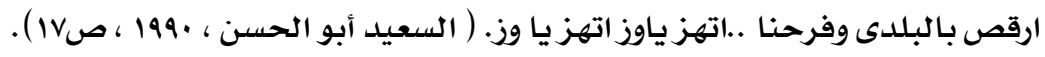

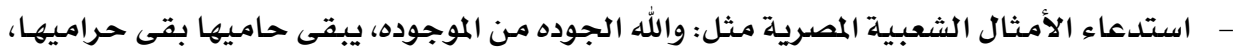

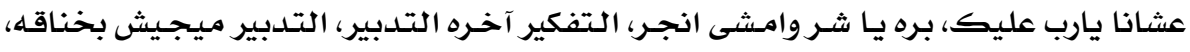

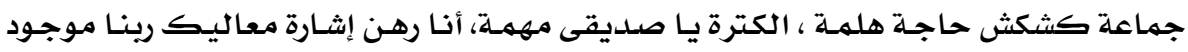

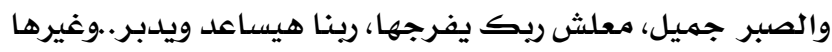

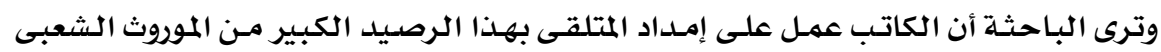

$$
\text { استجابة مـع توصيات التالية : }
$$

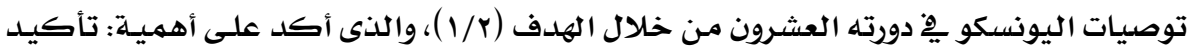

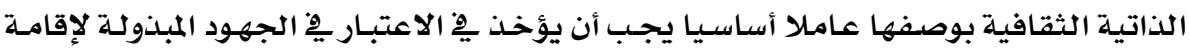

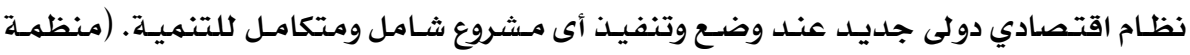

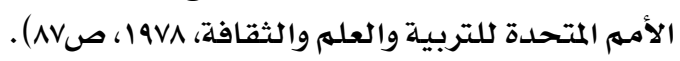

نجـــ ان صــراع المسـرحية لعسب دور كـبير فـى تطــوير الأحسداث والكسشف عـن مكنونـات

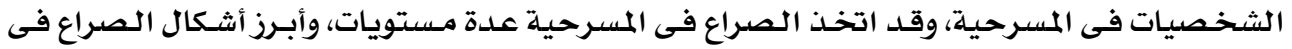

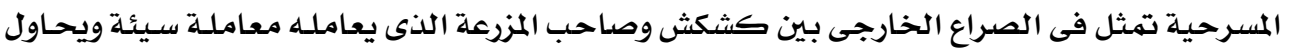

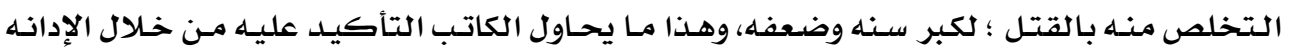

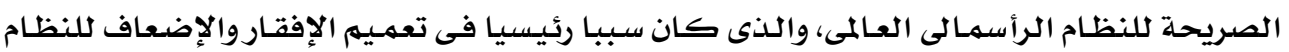

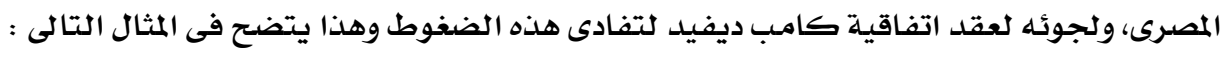


مجلة بحوث التربية النوعية - علد rأ - أبريل r.lV

صاحب المال: يغضب فجأة ... يدفع كشكش بقدمسه بعنف فيسقط على الأرض ..

تسقط نظارته وطاقم أسنانه - يدور باحثا عنها يتألم بصوت مكبوت فيوات

صاحب المال: أثناء ذلك يضحك شامتا ..ويضع العظمة فالطبق أمامه )

لا دا أنت خسارة فيك العظمة ولاعاد لك هيبـه ولا كلمـة

نظارة طبية وطقم اسنان دا ما عدش يجوز فيك الإنسان

أنا أحسن حاجة ارتاح منك فيه إيه حاكسبـه تانى منك

لو شفت الحرامية حاتهرب أخدلك واخلص منك بلدري

امشى امشى ما بنوكلشى عندى سلاحى حاديك بالنار

امشى امشى ما بنوكلشى امشى امشى ما بنوكلشى

كشش: (ينسحب كشكش خارجا ليختفي).

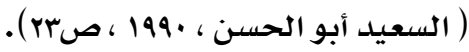

وكذلك الصراع الخارجى بين كشكث ومجموعـة الغربـاء الأشـرار التى تحساول استغلال

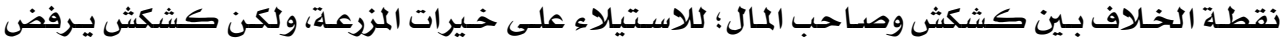

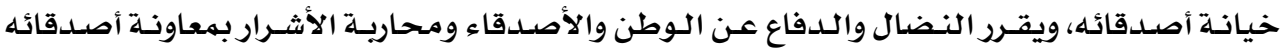

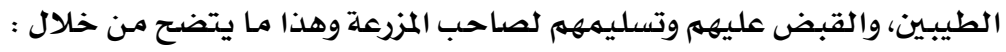

$$
\begin{aligned}
& \text { بمبم : (هامسة) ولا حد هنا } \\
& \text { الغراب : ولا حد هناك }
\end{aligned}
$$

بمبهم : راح نديهم حتة علقه .. بالهنا والشفا قولى انشا الله (يـدخلان فى خطوات حـذره

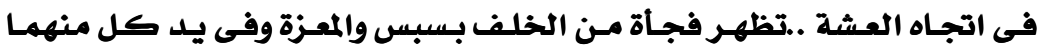

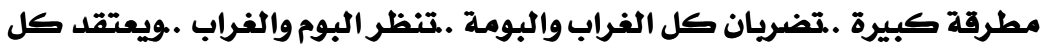

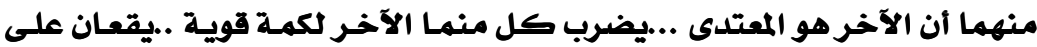

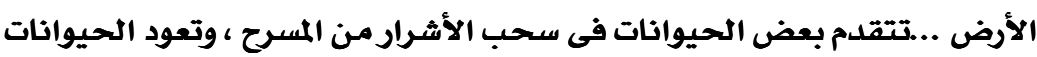

الطيبة لالاختفاء)

الفرخة : برافو يا بسبس .. الغراب مـات ..وبه به حصلته

$$
\begin{aligned}
& \text { بسبس : بطلى غلبه ...دا لسـه كتير } \\
& \text { كشكش : أنا شامهم ريحة شياطين } \\
& \text { جديو : لازم وحشو وأبو الأفكار . }
\end{aligned}
$$

(السعيد أبو الحسن ، • 199 ، ص (YV). 


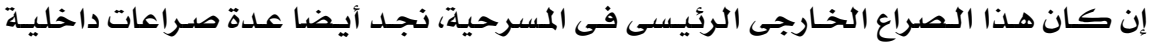

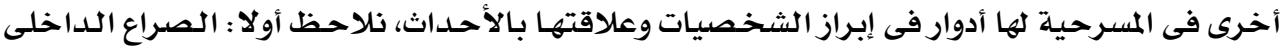

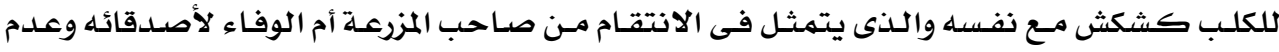

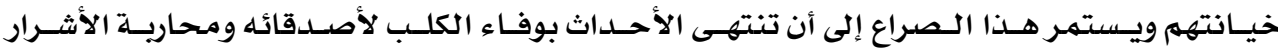
والانتصار عليهـ

$$
\text { أبو الافكار : احنا آهله شايفين بعنينا }
$$

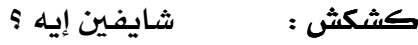

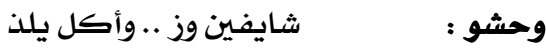

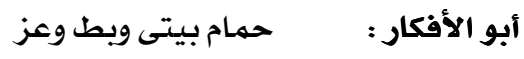

قوم هات لنا حاجـة قوم فز

وحشو :

يبقى حاميها بقى حراميها

كشكش:

إيـه اللى حاميها وإيـه حراميها

وحشو :

اياك ناوي تطلع تطلع فيها ؟؟؟

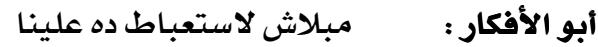

لا دنا حميها ولازم أحميها

كشكث:

عيب تخدعنا وأنت فى سنك

أبو الأفكار :

أأأأانا باخدعكم ؟؟

كشكش:

أيوه أمال دى اتفاقية جنتل أنهل

: الإثنتين :

(متلعثما ) !!!إ.ذذ ..اتفاقية إيه يا اخواننا.

: كشكش :

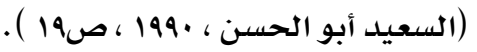

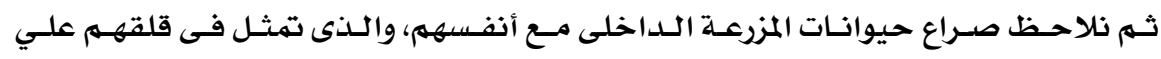

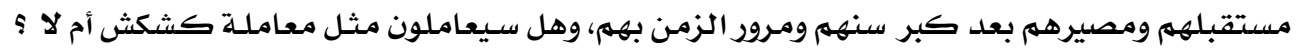

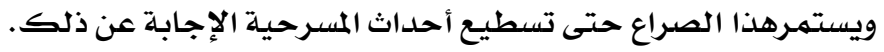
كوكى : ايه رأيك يا كبير جماعتنا

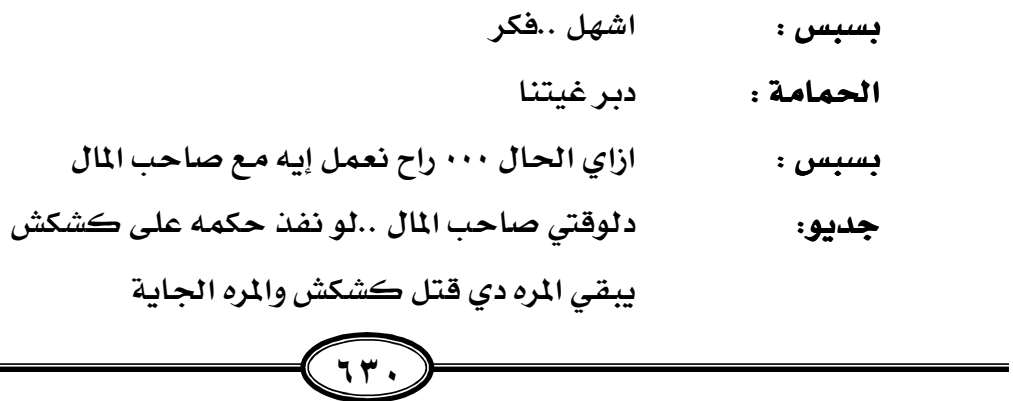




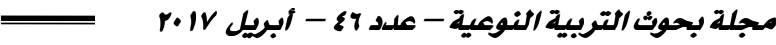

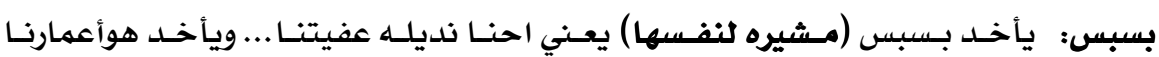

وفايدتنا

الفرخة: والآخر

كوكي: (تلاحقها بِ رنة بكاء) يقطع رقبتنا

جديو: (مستنكرا) بقى دا اسمه كلام

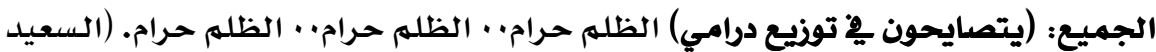

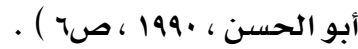

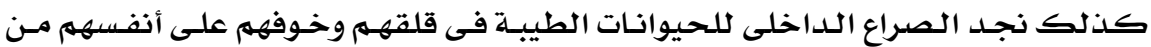

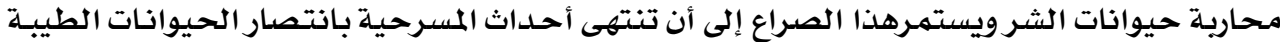

على مجموعة الأشرار.

بسبس : التفكير الصح ..ندافع ..عن عشتنا وعن كرمتنا ..وعن كل رملاية فى بيتنا

الأرنب : أنا عايز اسال ..مـين هيدافع

بسبس : (ناهرة غاضبة ) كلنا إيد واحده وحاندافع

الأرنب : بس قوليلى ذنبى أنا إيه ؟

الفرخة : آه .. وأنا .. ذنبي إيه ؟

كشكث: أنا يا اخواننا ..ما عنديث مانع

مهما أكون أنا سبع الليل

دى قضيتى سييبونى أدافع

المعزة : لا ياسى كشكث دى قضيتنا

دا الشر هيهجم على بيتنا.

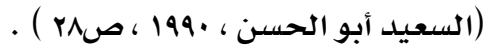

النهاية :

تختمم المسـرحية بنهايـة سـعيدة عادلـة يليهـا أغنيـة استعراضـية، تلعسب دورا دراميـا وتنويريـا

يؤكد القضية والمعني من جهه، وتبشر بنهاية الصهيونيه الأمريكية وبداية تحالف وتكامل عربى قوىى

كشكش : (لصاحب المال) التعلب والديب اتهدوا ..والشر أهو استلقى وعدوا

بسبس: اصحى ياحلو بلاث حركات .... والتعلب

الجميع: فات فات

بسبس: ويخ ديله 
الجميع: سبـع لفات .. سبع لفات...

أبوالأفكار: آه ياللى فى بالى حبستوني...ما نفعشي معاكم حركات

الجميع: التعلب آهو فات فات

أبوالافكار: الله لا يسيئكم تسيبوني

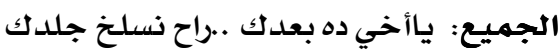

جلدك بيساوي ألووفاات

قولو فات فات وِِّ ديله سبـع لفات

والتعلب آهو فات فات

(السعيد أبو الحسن، • • 199، ص.بr)

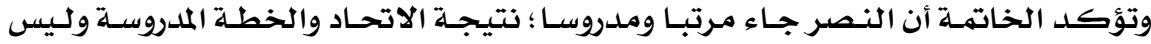

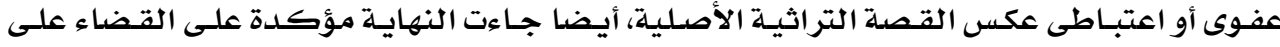

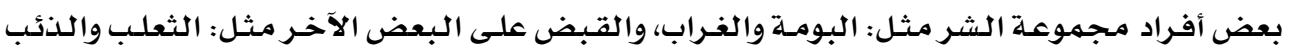

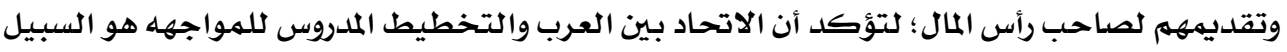
الوحيد للقضاء على المتربصين بالأمة العربية، وهى السبيل الوحيد لحـل كل مشاكلنا الاقتصادية

$$
\text { والسياسية والاجتماعية ...وغيرها }
$$

وهذا ما جاء مخالف للقصة الأصلية والتى تم فيها التصالح بـين الكلب سـلطون والدنئب،

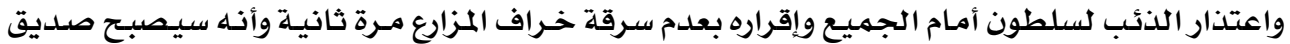

\section{هناقشة وفئة النتشائج:}

أولا : النتائج المتعلقة بالشكل :

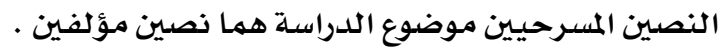

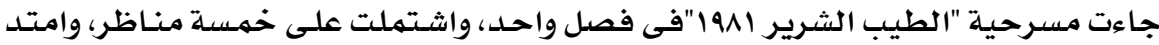

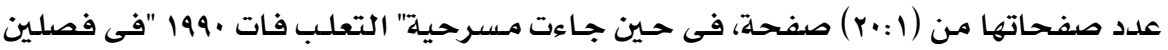

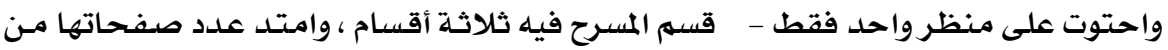

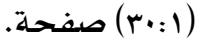

النصيين المسرحيين جاءا فى شكل أوبريتان غنائيان.

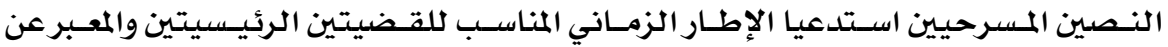

$$
\text { الواقعين المعاشين. }
$$

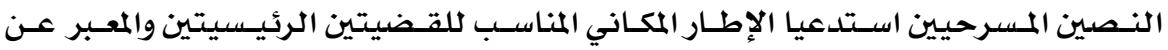

$$
\text { الواقعيين المعاشين. }
$$


ثانيا : النتائج المتعلقة بالمضموز :

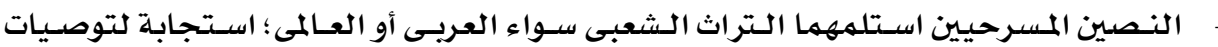

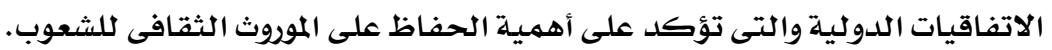

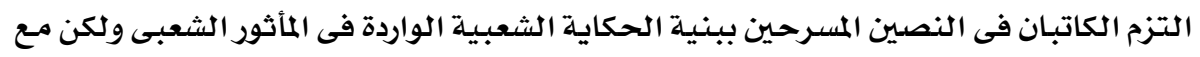

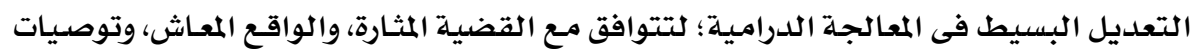

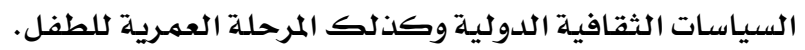

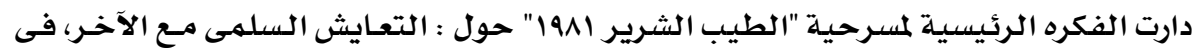

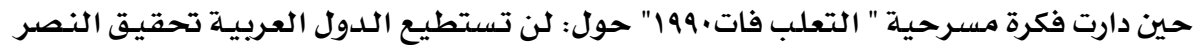

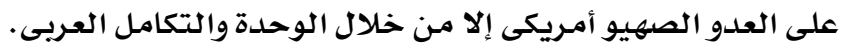

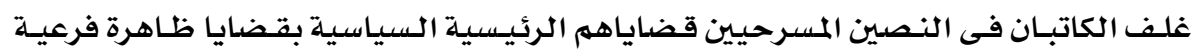

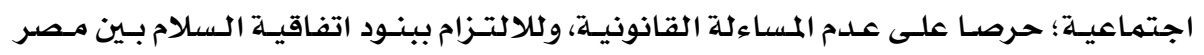
واسرائيل .

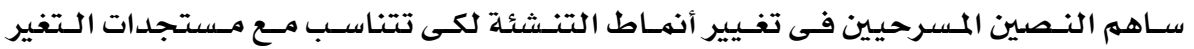
الاجتماعى المحلى والعربى والعالمى .

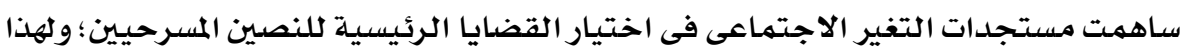

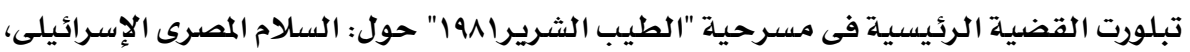

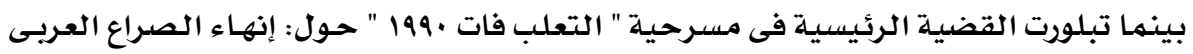

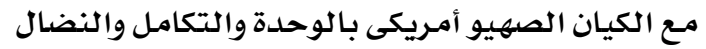

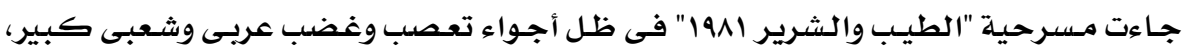

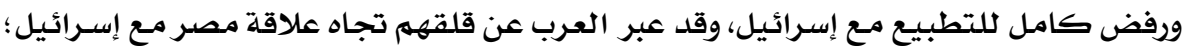

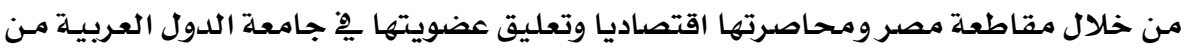

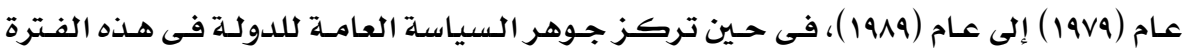

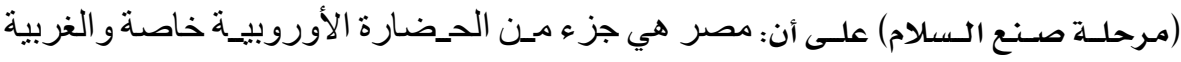

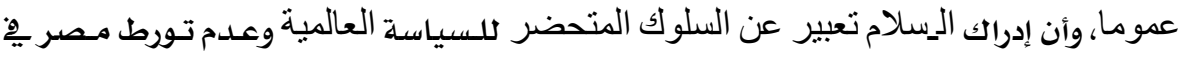

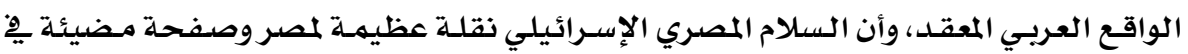

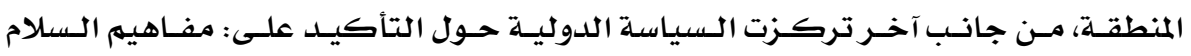

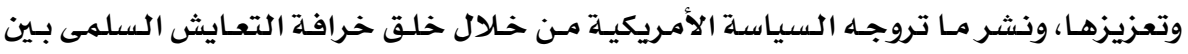

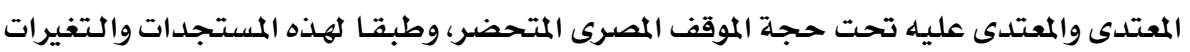

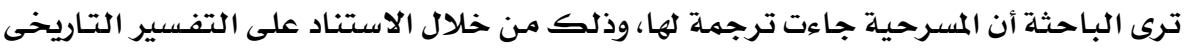

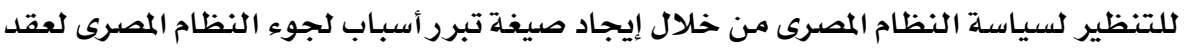

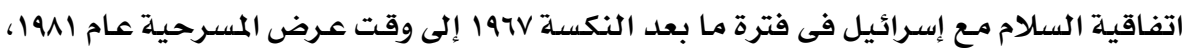

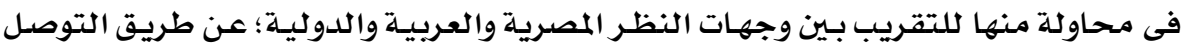

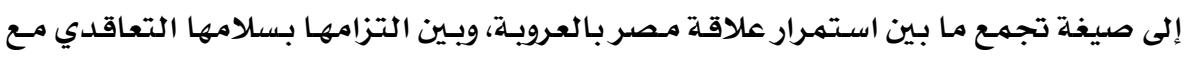


إسـرائيل، إلى جانب الالتـزام بتوصيات المنظمـات والمؤتمـرات الدوليـة والتـى تنـادى بأهميـة نشر

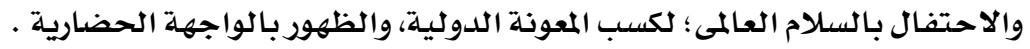

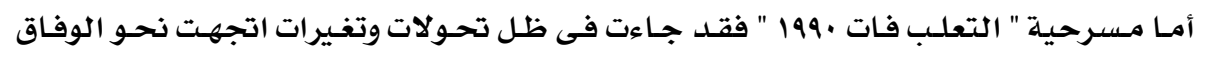

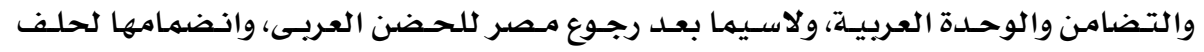

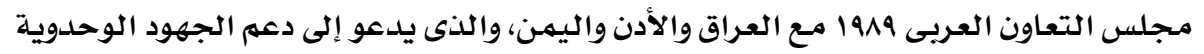

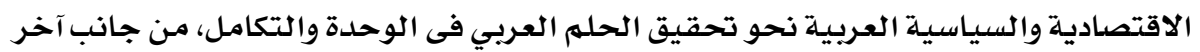

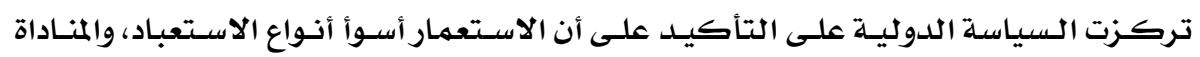

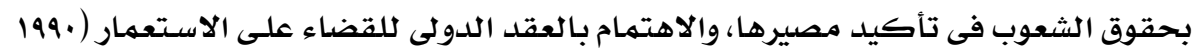

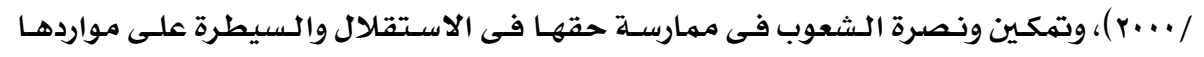

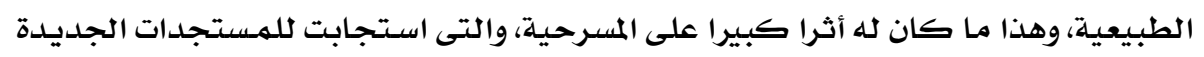

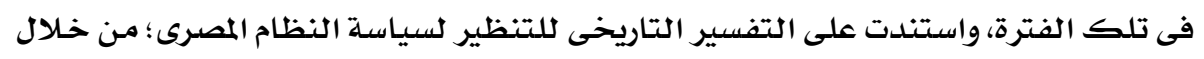

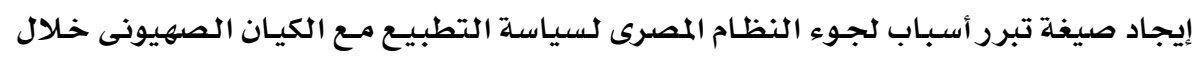

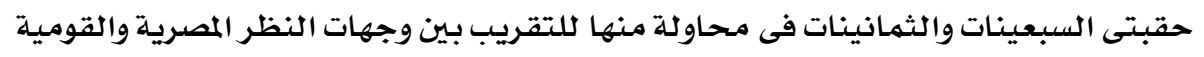

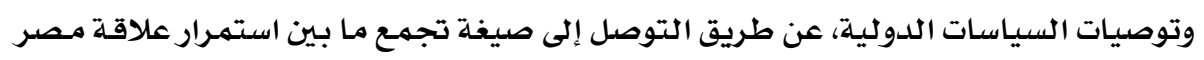

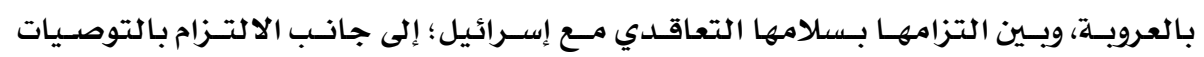

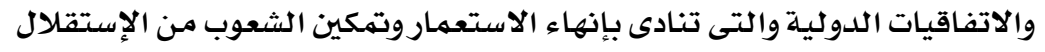

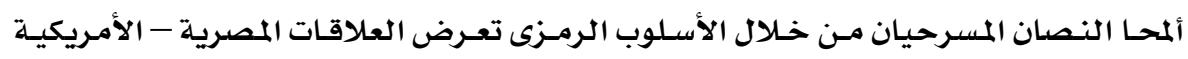

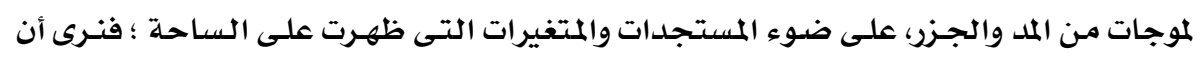

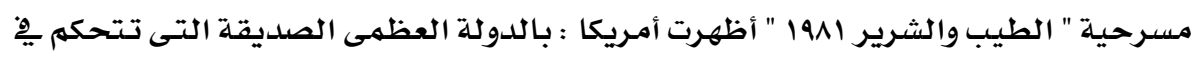

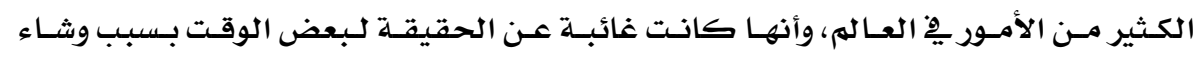

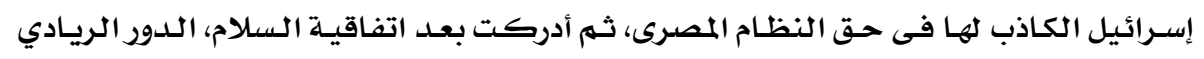

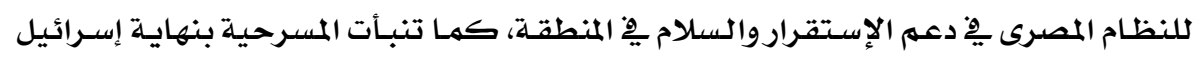

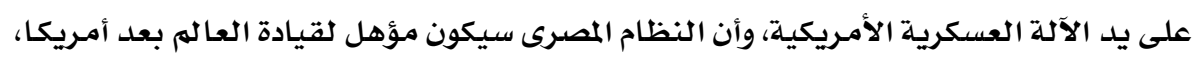

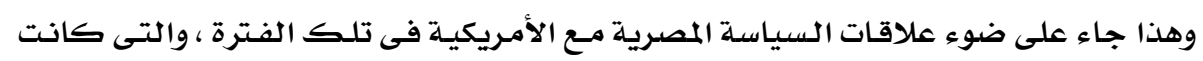

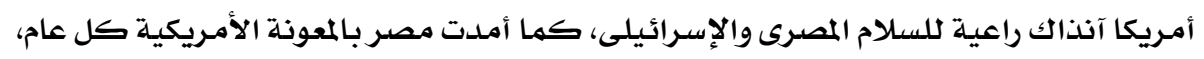

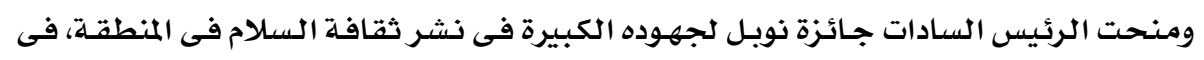

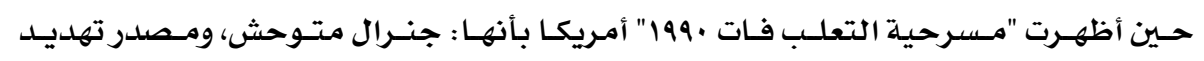

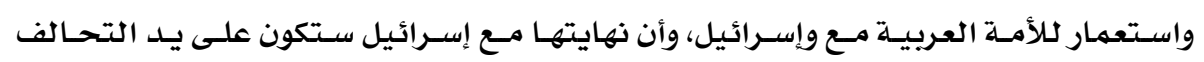

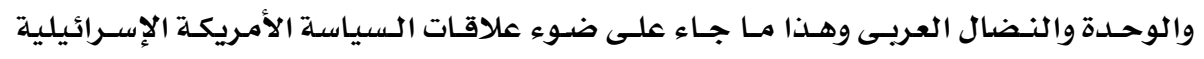

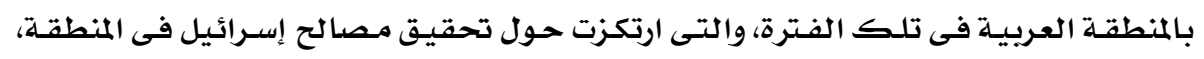

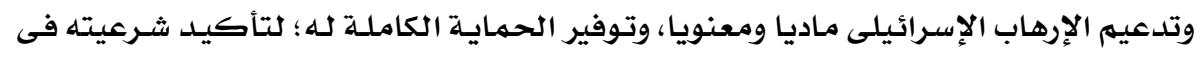

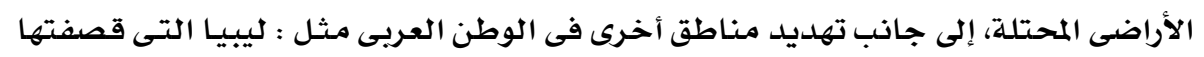
جويا وفرضت عليها حصارا اقتصاديا. 
أظهرا النصان المسرحيان مـن خـال الأسـلوب الرمـزى أن فترة نهايـة الثمانينـات شهـدت تحـولا

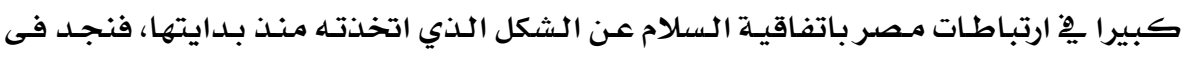

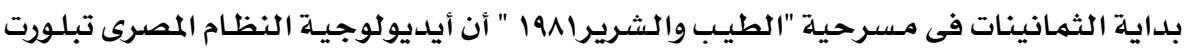

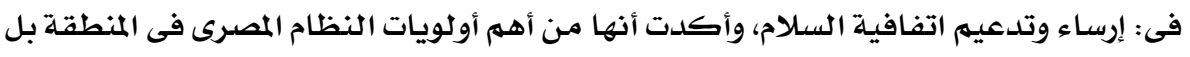

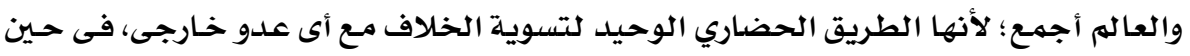

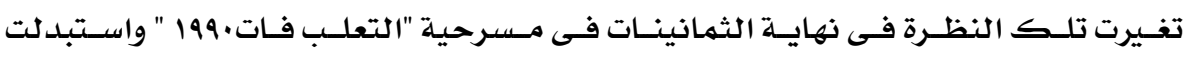

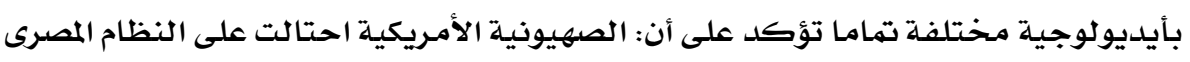

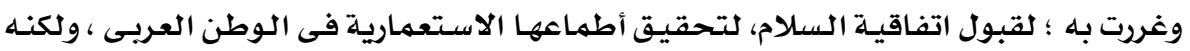

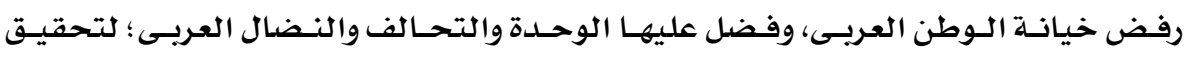

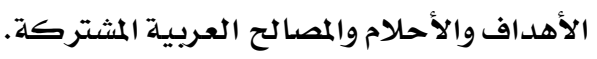

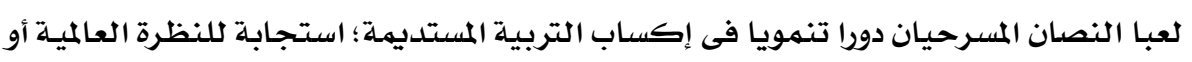

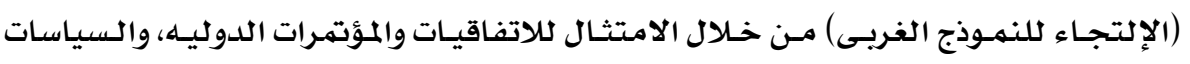

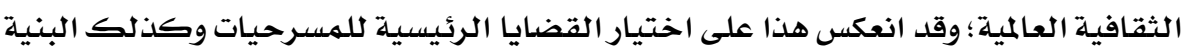
الدرامية للمسرحيات.

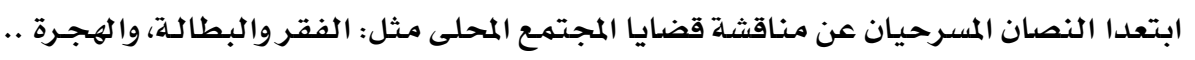

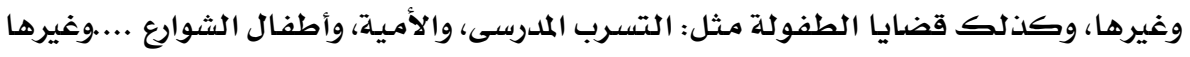

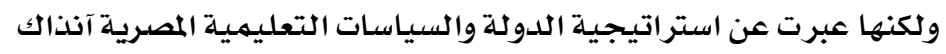

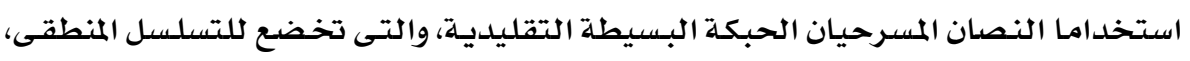

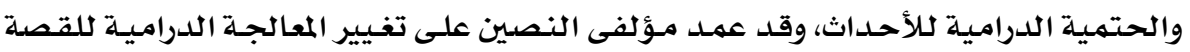

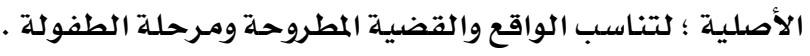

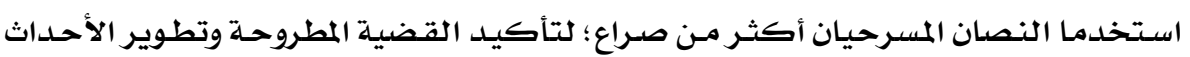
والكشف عن مكنونات الشخصيات.

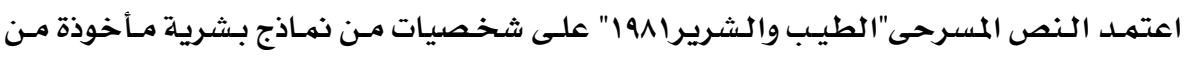

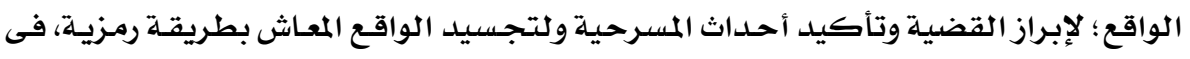

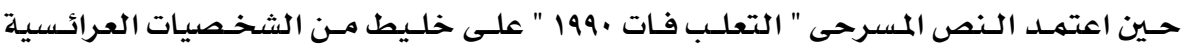

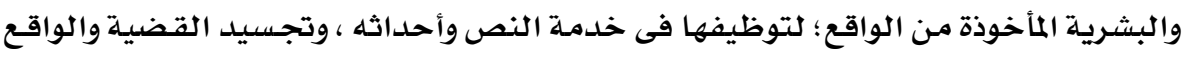

$$
\text { المعاش بطريقة رمزيية. }
$$

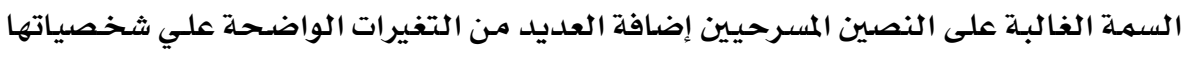

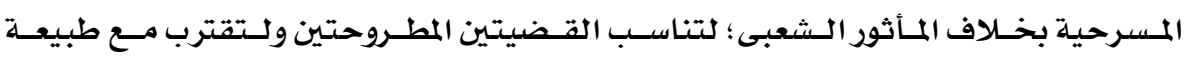
الشخصيات الموجودة فى الواقع

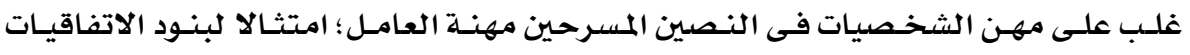
الدولية، والتى تؤكد على أن العمالة المنتجـة هى عنى النصر أساسى من عناصر التنمية. 


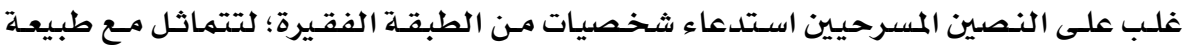

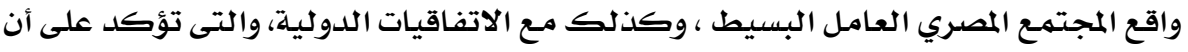

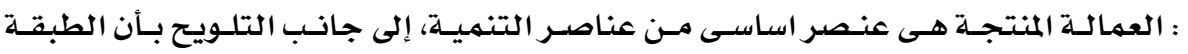

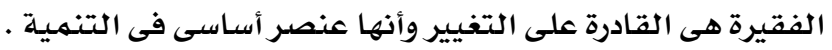

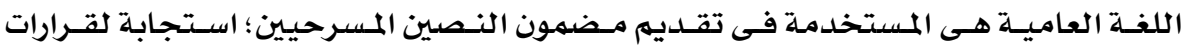

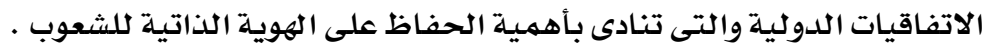

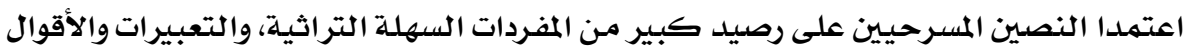

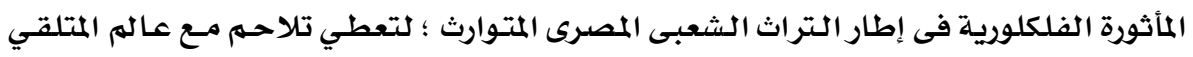

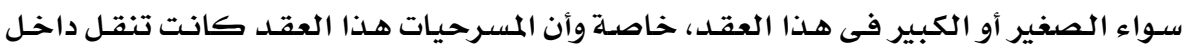
البيوت عن طريق التليفزيون أو الفيديو.

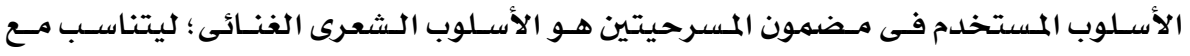

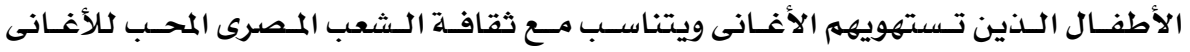

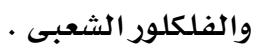

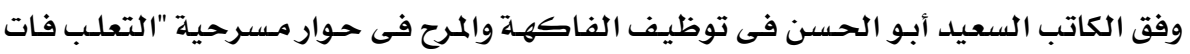

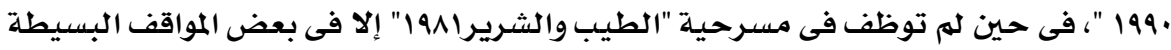

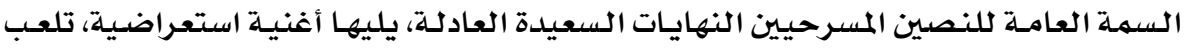

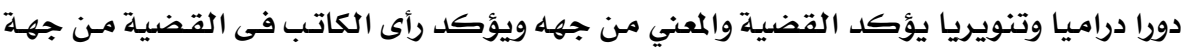
أخرى دورات درات

\section{توصيات الدراسة:}

فى ضوء النتائج الدراسة تقترح الدراسـة مجموعة من التوصيات من خلال التالى:

الاهتمام بنصوص مسرح الطفل وقضايا التغير الاجتماعى .

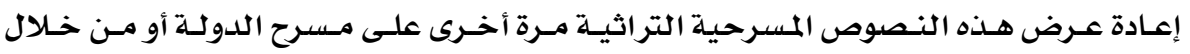

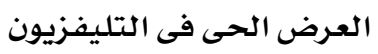

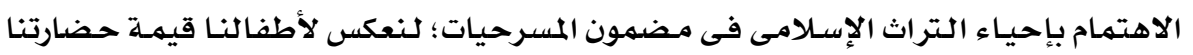

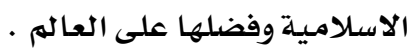

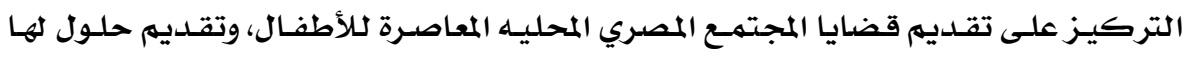

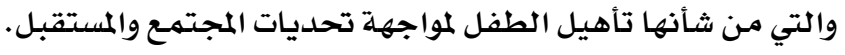

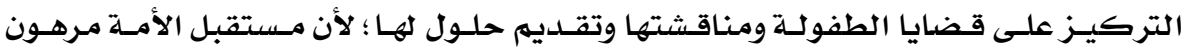

$$
\text { بمستقبل أطفالها . }
$$

النهوض بقضايا القومية العربية وتقديمها في مضمون المسرحيات ؛ لأنها الضمان لتحصدين

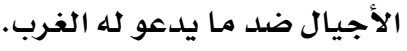


مجلة بحوث التربية النوعية - علد T أ - أبريل r.IV

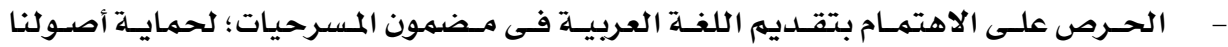

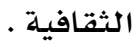

\section{البحوث المستقبلية المقتزحة للدراسة :}

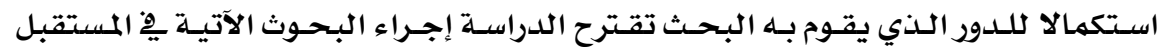

$$
\text { والتى قد تثرى مجال المسرحيات المنشورة للأطفال : }
$$

دراســة تحليليـة مقارنـة لقـضايا التتغير الاجتمـاعى بـين المسـرح القـومى ومسسرح

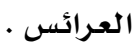

دراسة تحليلية لقضايا التغير الاجتماعى وانعكاسها على المسرح القومى لفترات

r

زمنية مختلفة.

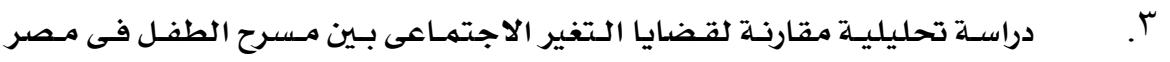

ومسرح الطفل فى أى دولة عربية اخرى .

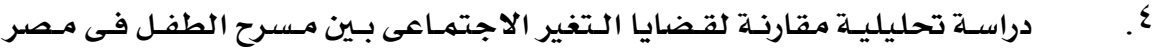

ومسرح الطفل فى أى دولة أجنبية أخرى.

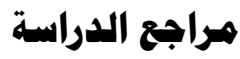

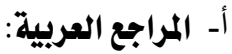

أولا : الربسائل العلمية:

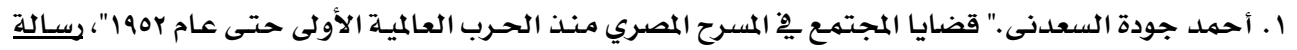

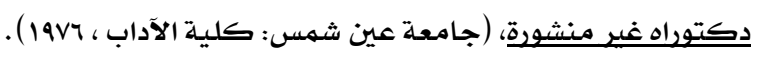

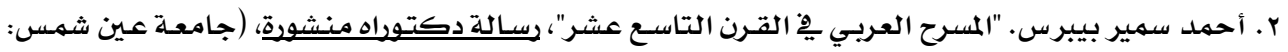

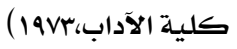

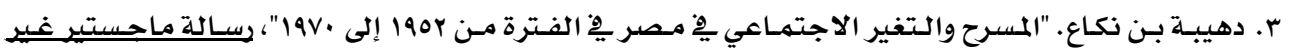

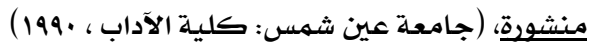

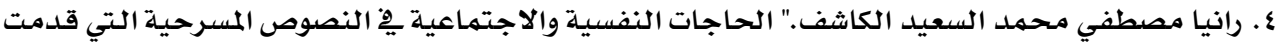

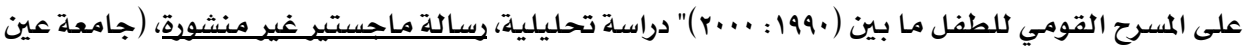

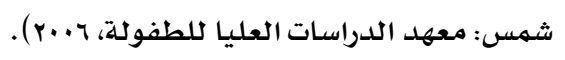

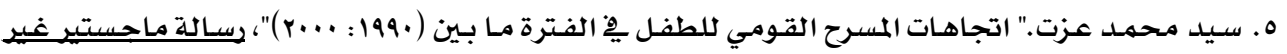

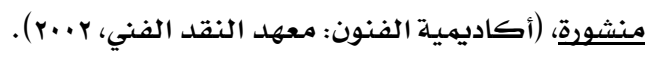

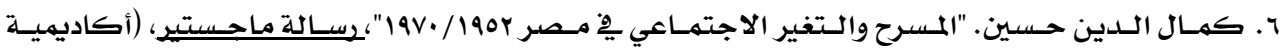

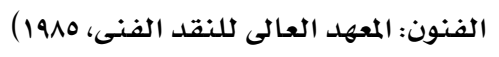

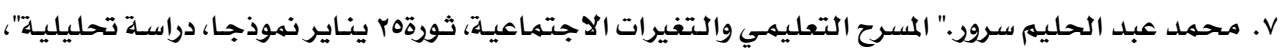

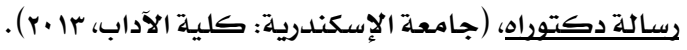




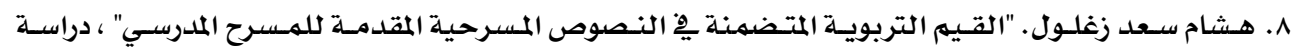

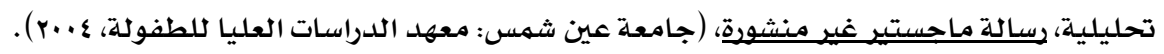

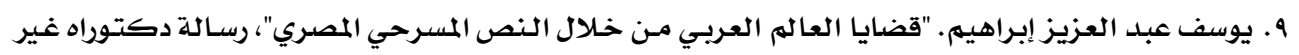

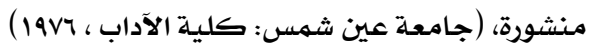

ثانيا: الكتب العربية:

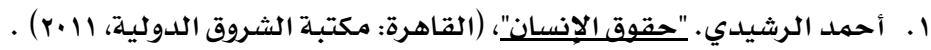

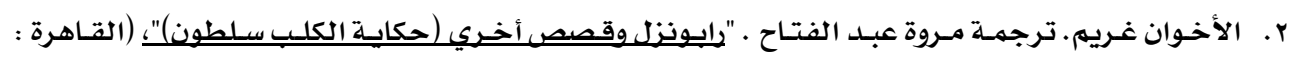

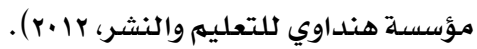

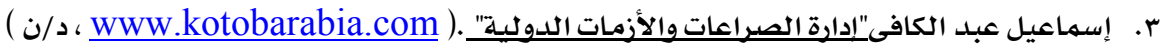

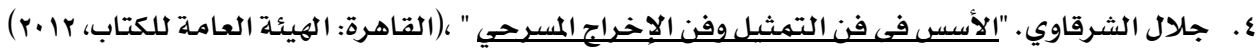

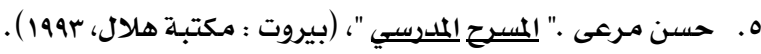

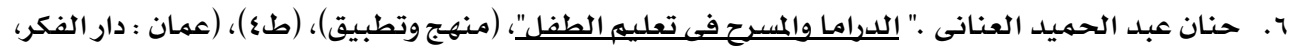
(1998

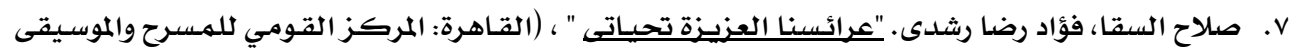

$$
\text { والفنون الشعبية ، د/ت). }
$$

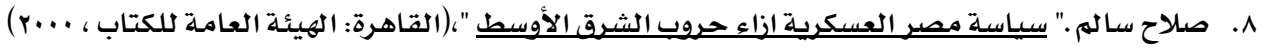

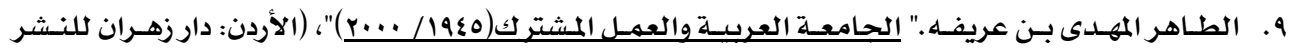

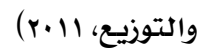

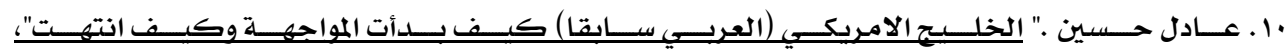

(1991، www.kotobarabia.com)

11 ا ـ عبد القادر القط. "فن المسرحيـة"، (القاهرة: الشركة المصرية العالمية للنشر- لونجمان، 19M1) .

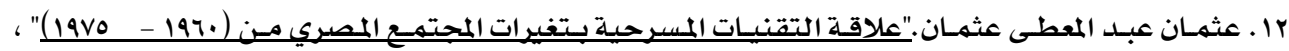

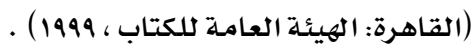

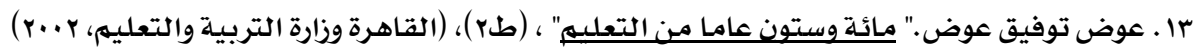

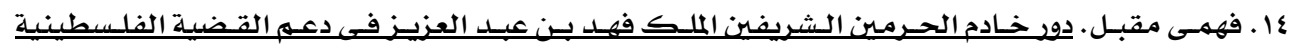

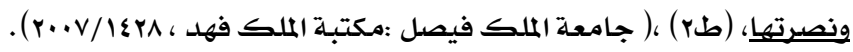

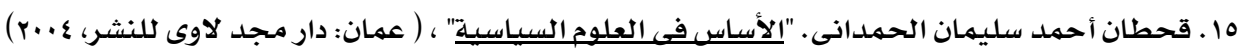

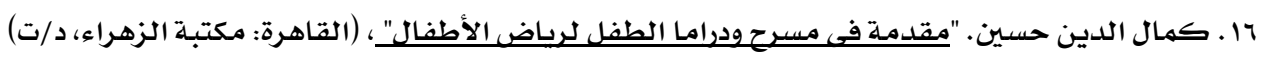
V ا . مجيد حميد الجبورى. "البنيـة الداخلية للمسرحية" (دراسات في الحبكة المسرحية عربيـا وعالميـا) ، (لبنـان:

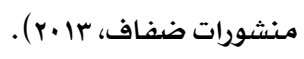

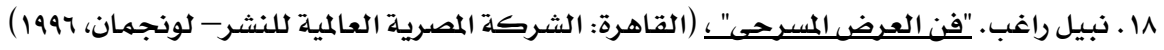

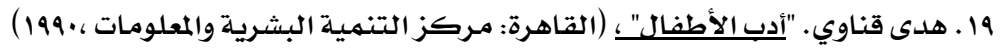




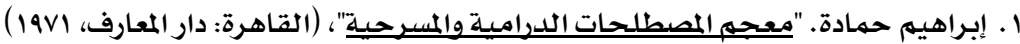

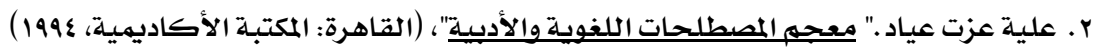
رابعا: مؤتمرات ودوريات:

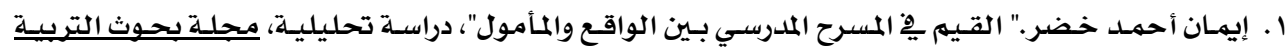

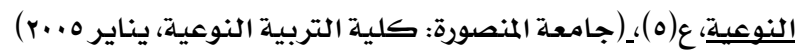

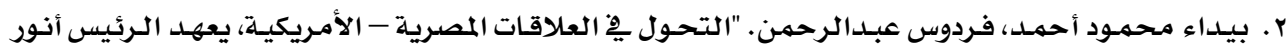

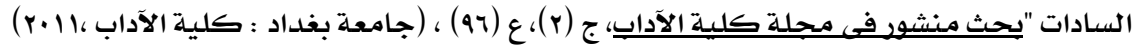
r. حسـين السيد حسين. "معاهدة السلام المصرية الإسـرائيلية عام 1979 وأثرها على دور مـصر الإقليمسي"، بحـث

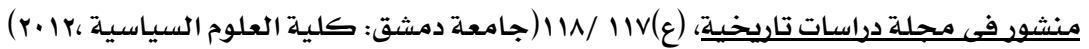

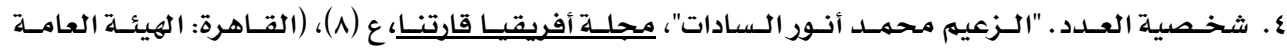

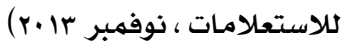
خامسا : تقارير ودوريات دولية:

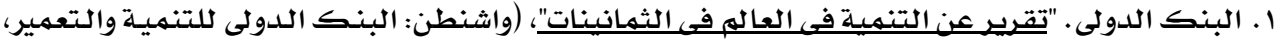
$(191$.

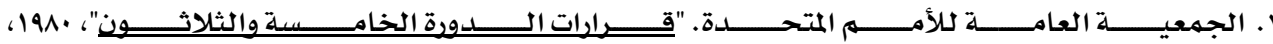
http://www.un.org/arabic/documents/GARes/35/GARes35all.htm

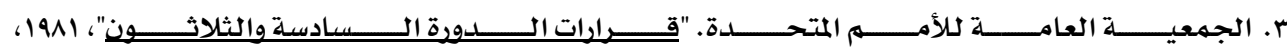
http://www.un.org/arabic/documents/GARes/36/GARes35all.htm

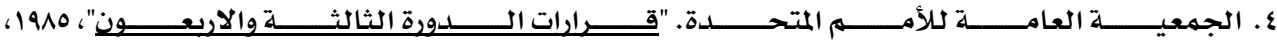
http://www.un.org/arabic/documents/GARes/43/GARes35all.htm ه. منظمة الأمهم المتحلدة للتربية والعلم والثقافة. "قرارات الدورة العشرون"، مـج (1)، (باريس: اليونسكو، (19VA،

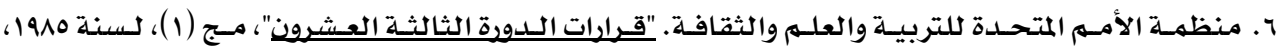

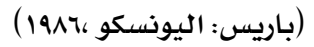

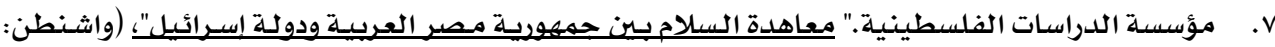
http://www.palestine-studies.org . ( $19 \vee 9 / r / r \uparrow$ سادسا: مقالات _2 الإنترنت: 1. الهيئة العامـة للاستعلامـات. " تحرير سيناء "، (د/ ن) http: // www. Sis. Gov. eg/ new VR/sinia/ html/ sina 01.htm

$$
\text { ץ. تركي الحمد." تركي الحمد يبحث يِ أسبـاب فشل الوحدة العربية (1)" ، (د/ن). }
$$

https://arabcenter.wordpress.com 
r. ذياب مخادمـة ." مجلس التعاون العربي. تجربة لم تكتمل"، (د/ن). http:/www.aljazeera.net/specialfiles/pages/eef66135-59af-42eb-bc44$5 \mathrm{~d} 23324 \mathrm{~b} 1 \mathrm{be} 1$

$$
\text { ع. سلامة كيلة ـ "الصراع الطبقى فى الوطن العربى فى الثمانينات ". ( / / / r ( ). }
$$
http://www.m.ahewar.org/s.asp?aid=240864\&r=0

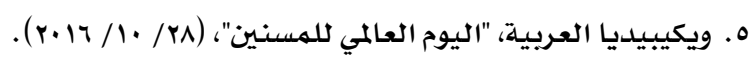

https://ar. Wikipedia. Org/wiki

4. موسوعة مقاتل ." جامعة الدول العربية وازمـة العلاقات المصرية العربية" ، (19v9 / 1919)" ، (د/ن). https://ar.www.moqatel.com/openshare/Behoth/Monzmat3/GamaArabi/sec07.doc-cvt.htm

$$
\text { V. محمد النابلسي." إن الله طيب ولا يقبل إلا طيباً " ( / / 1991/1). }
$$

http://www.nabulsi.com/blue/ar/artp.php?art=1134

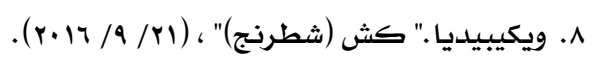

https://ar. wikipedia.org/wiki

$$
9 \text { 9. - معجم المعاني." معني شرير"، (د/ن). }
$$

http://www.almaany.com/ar/dict/ar-ar

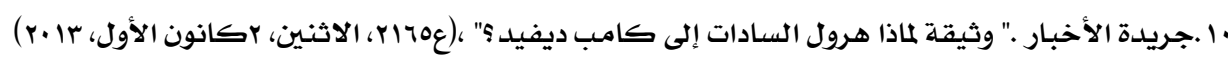
http://www.al-akhbar.com/node/196096

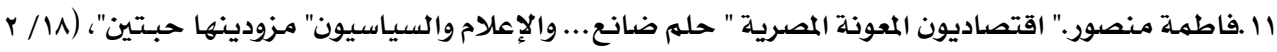
$(r \cdot 1 r /$

http://gate.ahram.org.eg/News/173574.aspx

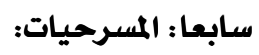

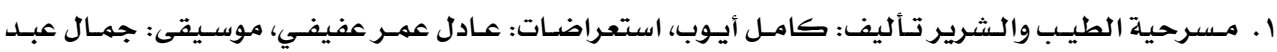

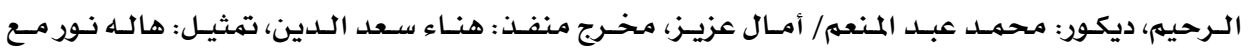

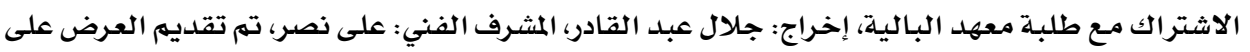

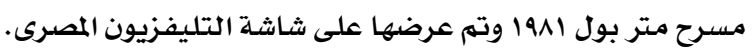

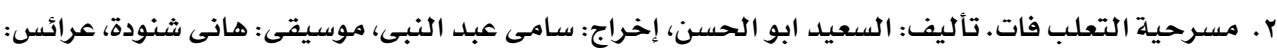

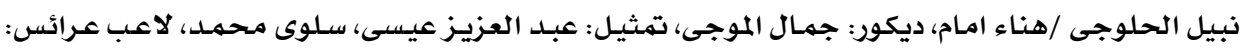




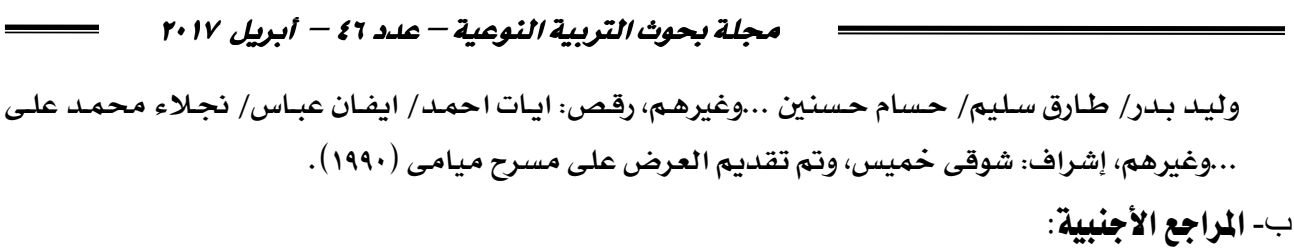

1. Eva Cristina, Vasquez . "Pregones Theatre : A theatre social change in the south Bronx ",Ph .D , ( New York : City University of New York , 2001)

2. Morrison, Joy Florence. "Communication and social change : A case study of forum theater in Burkina Faso",Ph.D, (Spain : University de Valelcia ,1991)

3. Paavolainen ,Panttijalmari .TeatteriJasuurimuutto (1959 -1971), F.T, (Finland : HelsinginYiopisto (Finland) 1992).

4. Rundnicka- Kassem,Dorota. "Egyptian Drama and social change ;A study of the matic and artistic development in Yusuf Idris's Plays",Ph. D , (Canada : McGill university , 1992 ).

5. Sukhwant Hundal B.A. "Theater for Social Change in the Punjab State of India" , M.A, (Canada : Simon Fraser University, 2002) 
Social change issues in some plays, children's theater in the eighties

\section{Abstract}

The study aimed to identify the social change issues in the two texts playwrights Tayeb and Alshsharir 1981" and "Altalb Fat 1990, and reveal the dramatic treatment of the issues of social change in which ways, the study used the analytical method cash Objective, and a tool content analysis to analyze a sample intentional strong texts playwrights were presented to the National theater for the child in the eighties.

\section{And it concluded:}

- Developments in social change contributed to the selection of cases for texts playwrights and crystallized the key issue in the text of a " Tayeb and Alshsharir 1981" on the Egyptian-Israeli peace, while the text of " Altalb Fat 1990 " about: ending the Arab conflict with the Zionist entity, US unity and integration and struggle. 